ANLEAIS-6, Rev. 0

\title{
RISKIND - A Computer Program for Calculating Radiological Consequences and Health Risks from Transportation of Spent Nuclear Fuel
}

by Y.C. Yuan,* S.Y. Chen, D.J. LePoire, and R. Rothman*

Environmental Assessment and Information Sciences Division, Argonne National Laboratory, 9700 South Cass Avenue, Argonne, Illinois 60439

February 1993

Work sponsored by United States Department of Energy, Office of Civilian Radioactive Waste Management

"Yuan is affiliated with Square Y Consultants, Orchard Park, New York, and Rothman with the U.S. Department of Energy, Idaho Falls, Idaho.

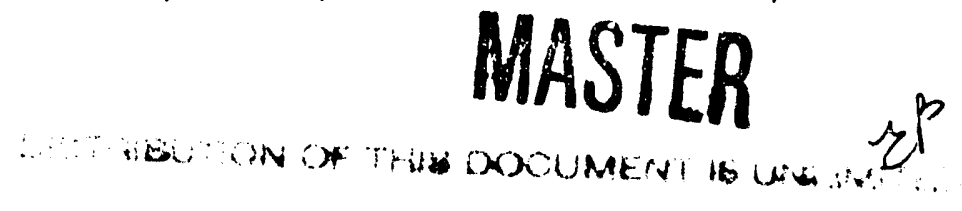




\section{CONTENTS}

ACKNOWLEDGMENTS $\ldots \ldots \ldots \ldots \ldots \ldots \ldots \ldots \ldots \ldots \ldots \ldots \ldots \ldots \ldots \ldots$ viii

AVAILABILITY OF COMPUTER SOFTWARE $\ldots \ldots \ldots \ldots \ldots \ldots \ldots$ ix

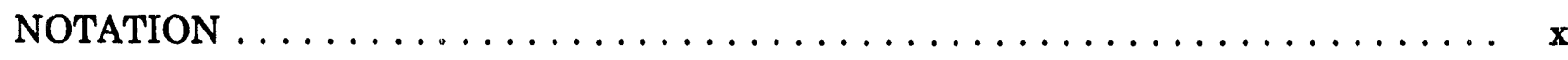

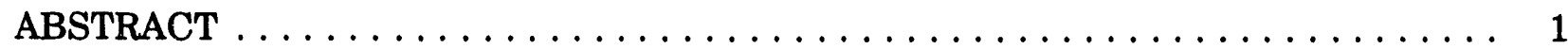

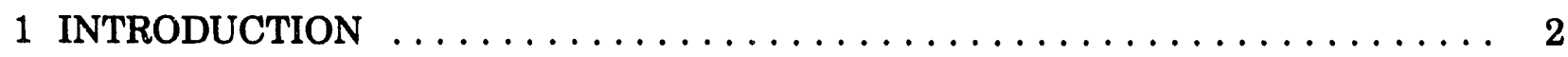

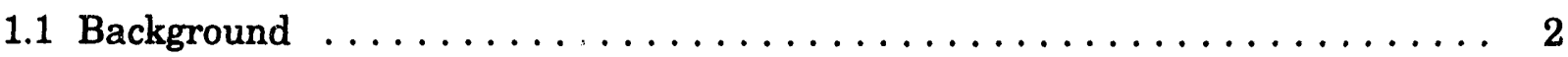

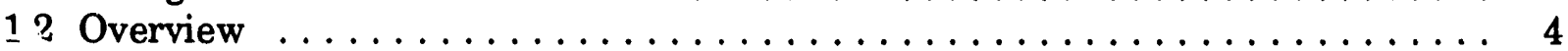

2 METHODOLOGY FOR DOSE CALCULATIONS $\ldots \ldots \ldots \ldots \ldots \ldots \ldots$

2.1 Radiological Hazard from Incident-Free Transportation $\ldots \ldots \ldots \ldots \ldots \ldots$

2.1.1 External Dose Model . . . . . . . . . . . . . . . . . . . . 9

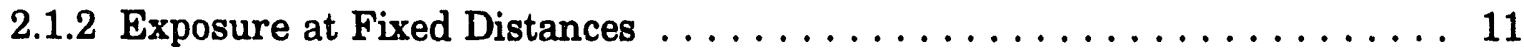

2.1.3 Exposure from a Passing Shipment . . . . . . . . . . . . . . . 13

2.1.4 Cask Dimensions and Other Key Parameters . . . . . . . . . . . . . 15

2.2 Radiological Hazard from Accidents . . . . . . . . . . . . . . . . . 16

2.2.1 Accident Response and Release Model . . . . . . . . . . . . 16

2.2.1.1 Cask Response . . . . . . . . . . . . . . . . . 16

2.2.1.2 Release Fractions . . . . . . . . . . . . . . . . . 21

2.2 .2 Individual Dose Model . . . . . . . . . . . . . . . . . . . 23

2.2.2.1 Atmospheric Transport Model . . . . . . . . . . . . . . 23

2.2.2.2 Environmental Pathway and Dosimetry Models . . . . . . . . 37

2.2.2.3 Short-Term Exposure ..................... 40

2.2.2.4 Long-Term Exposure . . . . . . . . . . . . . . . 43

2.2.2.5 Long-Term Dose Models . . . . . . . . . . . . . . 54

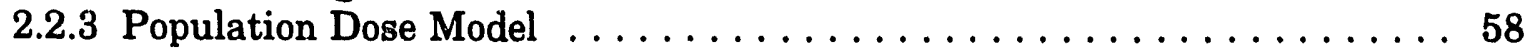

2.2.3.1 Concentration Isopleth and Contaminated Areas . . . . . . . . 58

2.2.3.2 Dose Models . . . . . . . . . . . . . . . . . . . 60

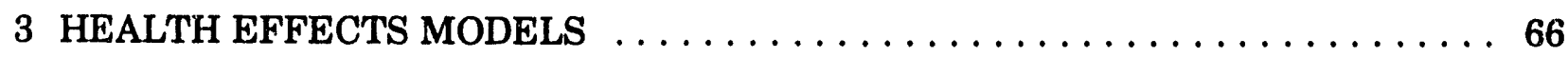

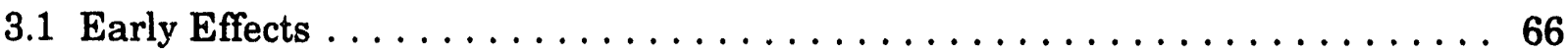

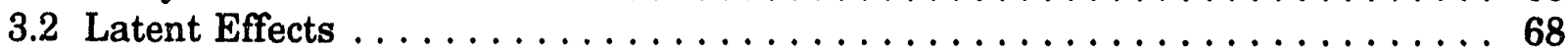

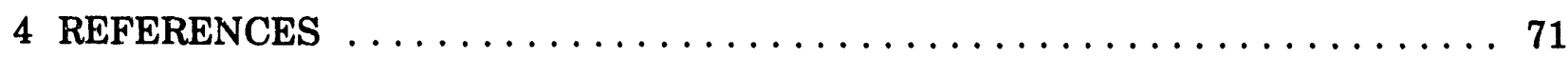

APPENDIX A: Description of Radionuclide Inventory Database for Spent Nuclear Fuels . . . . . . . . . . . . . . . . 75

APPENDIX B: Method for Adjusting Cask External Dose Rates Relative to Cask Dimensions .................... 81 


\section{CONTENTS (Cont.)}

APPENDIX C: Method for Screening Radionuclides . . . . . . . . . . . . . 87

APPENDIX D: Method for Estimating the Spallation of Crud Material . . . . . . . 95

APPENDIX E: Method for Estimating Cask Response from User-Specified

Accident Scenarios . . . . . . . . . . . . . . . . . . 103

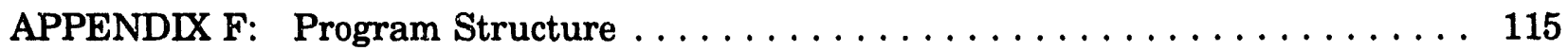

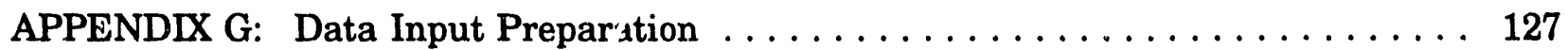

APPENDIX $\mathbf{i}:$ Sample Problems $\ldots \ldots \ldots \ldots \ldots \ldots \ldots \ldots \ldots \ldots \ldots \ldots \ldots$

\section{TABLES}

2.1 Coefficients of the Fitted Equations for Neutron and Gamma Dose

Rates from a Spent Fuel Cask, with Groundscattering . . . . . . . . . . . . 12

2.2 Comparison of Preliminary Design Characteristics of DOE Initiative I and NRC Modal Study Spent Nuclear Fuel Transportation Casks . . . . . . . . 17

2.3 Sample of External Dose Information Based on DOE's Initiative I GA-4 Truck Cask for a PWR . . . . . . . . . . . . . . . . . . . . . .

2.4 Radioactive Material Release Fractions from Accidents Occurring under Various Cask Response Regions . . . . . . . . . . . . . . .

2.5 Dispersion Coefficients for Elevated Releases $\ldots \ldots \ldots \ldots \ldots \ldots \ldots$

2.6 Dispersion Coefficients for Ground-Level Releases $\ldots \ldots \ldots \ldots \ldots \ldots$

2.7 Deposition Velocity Data Summary for Particulate Radionuclides . . . . . . . . 36

2.8 Transfer Coefficients Applicable to Food Chain Pathways

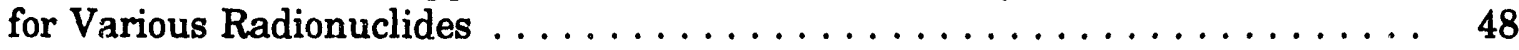

2.9 Default Time-Integrated Relative Ground-Level Air Concentration Limits Used to Calculate Contaminated Areas . . . . . . . . . . . . . . . 61

3.1 Estimated Lifetime Cancer Mortalities and Genetic Effects . . . . . . . . 70

A.1 Sample Radionuclide Inventory $\ldots \ldots \ldots \ldots \ldots \ldots \ldots \ldots \ldots$

D.1 Crud Surface Activity Density at Time of Fuel Discharge $\ldots \ldots \ldots \ldots$ 


\section{TABLES (Cont.)}

D.2 Current Cask and Fuel Assembly Design Parameters ............... 100

D.3 Spallation Values for NRC Modal Study Cask Response Regions . . . . . . 100

E.1 Impact Velocities Required to Attain $0.2 \%, 2 \%$, and $30 \%$ Strain Levels

for Objects Impacted in Highway and Railway Accidents . . . . . . . . . 108

E.2 Fire Duration Required to Reach the Four Levels of Lead

Midlayer Thickness Temperatures for a $1,700^{\circ} \mathrm{F}$ Engulfing Fire . . . . . . . 109

E.3 Heat Flux Factors for Flame Temperatures $\ldots \ldots \ldots \ldots \ldots \ldots \ldots \ldots$

E.4 Response Regions Categorized by Vessel Strain and Lead Midlayer

Thickness Temperature $\ldots \ldots \ldots \ldots \ldots \ldots \ldots \ldots \ldots \ldots \ldots \ldots$

F.1 Major Common Blocks Used in RISKIND $\ldots \ldots \ldots \ldots \ldots \ldots \ldots \ldots \ldots$

G.1 Description of Input Parameters $\ldots \ldots \ldots \ldots \ldots \ldots \ldots \ldots \ldots \ldots \ldots \ldots$

\section{FIGURES}

1.1 Flow Diagram of Radiological Risk to an Individual from

Transportation of Spent Nuclear Fuel $\ldots \ldots \ldots \ldots \ldots \ldots \ldots \ldots$

2.1 Configuration of Spent Fuel Cask Relative to the Receptor and

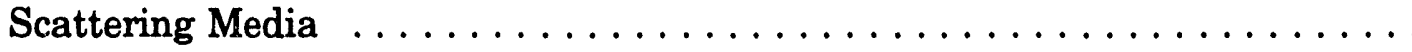

2.2 Schematic Diagram of External Exposures to Various

Population Groups from a Moving Shipment of Spent Fuel Casks . . . . . . . 14

2.3 Matrix of Cask Response Regions and Probabilities of Occurrence

for Combined Mechanical and Thermal Loads . . . . . . . . . . . . . 20

2.4 Environmental Pathways and Exposure Modes for a

Spent Nuclear Fuel Cask Accident $\ldots \ldots \ldots \ldots \ldots \ldots \ldots \ldots \ldots, 38$

2.5 Areas of Air Concentration Contours for Population Dose Calculation . . . . . . 60

B.1 Schematic Diagram Correlating Doses to Cask Dimensions $\ldots \ldots \ldots \ldots . . \ldots 4$

E.1 Representative Truck Cask Design Used for Dynamic Structural

and Thermal Response Studies . . . . . . . . . . . . . . . . . . 106

E.2 Representative Rail Cask Design Used for Dynamic Structural and Thermal Response Studies . . . . . . . . . . . . . . . . . . . . . . . 106 


\section{FIGURES (Cont.)}

E.3 Three Impact Loading Parameters Considered in the Response Analysis for Impacts on Surfaces $\ldots \ldots \ldots \ldots \ldots \ldots \ldots \ldots \ldots$

E.4 Flow Diagram Used in RISKIND to Determine Cask Response Regions . . . . 113

F.1 Hierarchy Diagram for Main RISKIND Program $\ldots \ldots \ldots \ldots \ldots \ldots \ldots$

F.2 Hierarchy Diagram for Subroutine PART1 . . . . . . . . . . . . . 119

F.3 Hierarchy Diagram for Subroutine EXTERNL $\ldots \ldots \ldots \ldots \ldots \ldots \ldots \ldots$

F.4 Hierarchy Diagram for Subroutine PUFIND $\ldots \ldots \ldots \ldots \ldots \ldots \ldots \ldots 121$

F.5 Hierarchy Diagram for Subroutine ACUTE $\ldots \ldots \ldots \ldots \ldots \ldots \ldots \ldots \ldots$

F.6 Hierarchy Diagram for Subroutine TMDOS $\ldots \ldots \ldots \ldots \ldots \ldots \ldots \ldots$

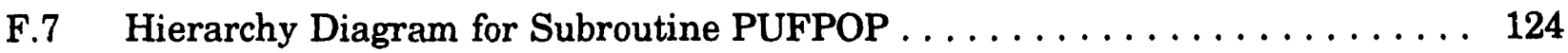

G.1 Main Menu of RISKIND System $\ldots \ldots \ldots \ldots \ldots \ldots \ldots \ldots \ldots \ldots \ldots$

G.2 Input Screen of RISKIND System, Category $1 \ldots \ldots \ldots \ldots \ldots \ldots \ldots$

G.3 Input Screen of RISKIND System, Category $2 \ldots \ldots \ldots \ldots \ldots \ldots \ldots$

G.4 Input Screen of RISKIND System, Category $3 \ldots \ldots \ldots \ldots \ldots \ldots$

G.5 Main Input Screen of RISKIND System, Category $4 \ldots \ldots \ldots \ldots \ldots \ldots$

G.6 Additional Input Screen of RISKIND System, Category $4 \ldots \ldots \ldots \ldots \ldots 144$

G.7 Input Screen of RISKIND System, Category 4 for User-Defined Scenario . . . 145

G.8 Input Screen of RISKIND System, Category $5 \ldots \ldots \ldots \ldots \ldots \ldots \ldots$

G.9 Additional Input Screen of RISKIND System, Category $5 \ldots \ldots \ldots \ldots 146$

G.10 Additional Input Screen of RISKIND System, Category $5 \ldots \ldots \ldots \ldots \ldots$

G.11 Additional Input Screen of RISKIND System, Category $5 \ldots \ldots \ldots \ldots 147$

G.12 Input Screen of RISKIND System, Category $6 \ldots \ldots \ldots \ldots \ldots \ldots \ldots$

G.13 Additional Input Screen of RISKIND System, Category $6 \ldots \ldots \ldots \ldots 148$

G.14 Input Screen of RISKIND System, Category $7 \ldots \ldots \ldots \ldots \ldots \ldots \ldots$ 


\section{FIGURES (Cont.)}

G.15 Additional Input Screen of RISKIND System, Category $7 \ldots \ldots \ldots \ldots$

G.16 Input Screen of RISKIND System, Category $8 \ldots \ldots \ldots \ldots$

G.17 Input Screen of RISKIND System, Category $9 \ldots \ldots \ldots \ldots$

G.18 Input Screen of RISKIND System, Category $10 \ldots \ldots \ldots \ldots \ldots$

H.1 Individual Doses versus Conditional Accident Probabilities . . . . . . . . . 157 


\section{ACKNOWLEDGMENTS}

The authors wish to express their thanks to the U.S. Department of Energy (DOE) Office of Civilian Radioactive Waste Management (OCRWM) for funding this project. Leadership of this project has been provided by DOE program manager Michael Conroy. Special thanks are due to Edwin Wilmot (formerly with DOE OCRWM) for the inception of the program and to Jeffrey Roberts and Michael Klimas of DOE Chicago for their continued administrative support.

Many constructive comments and suggestions were received from several experts who reviewed the document. The authors wish to thank Carl Gertz (Yucca Mountain Project Office) and his support staff: Jeffery Tappen (Westinghouse Electric Co.); Thomas McSweeney (Battelle Memorial Institute); Robert Luna, Sieglinde Neuhauser, Nancy Russell, and Michael Vannoni (Sandia National Laboratories); Ronald Pope, Lawrence Shappert, and Scott Ludwig (Oak Ridge National Laboratory); Edward Bradley and Steven Woolfolk (Science Applications International Co.); and John Mayer (TRW Environmental Safety Systems Inc.). Useful discussion and input have also been received from William Andrews (Science Applications International Co.).

Finally, we thank Pat Hollopeter for editorial assistance and the Information and Publishing Division Document Processing Center for document preparation. 


\section{AVAILABILITY OF COMPUTER SOFTWARE}

Electronic copies of the software describer in this publication will be distributed with appropriate restrictions by:

Energy Science and Technology Software Center

P.O. Box 1020

Oak Ridge, Tennessee 37831-1020

For information regarding requests for software, call (615) 576-2606. 


\section{NOTATION}

The following is a list of acronyms, initialisms, and abbreviations (including units of measure) used in this document. Some acronyms used in tables only are defined in the respective tables.

\section{ACRONYMS, INITIALISMS, AND ABBREVIATIONS}

BEIR Committee on the Biological Effects of Ionizing Radiation

BWR boiling-water reactor

CFR

DOE

DOS

DREF

EA

EPA

IAEA

ICRP

LET Code of Federal Regulations

U.S. Department of Energy

disk operating system

dose-rate effectiveness factor

environmental assessment

U.S. Environmental Protection Agency

International Atomic Energy Agency

International Commission on Radiological Protection

linear energy transfer

LLNL Lawrence Livermore National Laboratory

LWR light-water reactor

NEPA

NRC

OCRWM

ORNL

PWR

TI

National Environmental Policy Act

U.S. Nuclear Regulatory Commission

Office of Civilian Radioactive Waste Management

Oak Ridge National Laboratory

pressurized-water reactor

transport index

UNSCEAR

United Nation's Scientific Committee on the Effects of Ionizing Radiation

\section{UNITS OF MEASURE}

$\begin{array}{ll}\mathrm{cal} & \text { calorie(s) } \\ \mathrm{Ci} & \quad \text { curie(s) } \\ \mathrm{pCi} & \quad \text { picocurie(s) } \\ \mu \mathrm{Ci} & \text { microcurie(s) } \\ \mathrm{cm} & \text { centimeter(s) } \\ \mathrm{cm}^{2} & \text { square centimeter(s) } \\ \mathrm{d} & \text { day(s) } \\ \mathrm{ft} & \text { foot (feet) } \\ { }^{\circ} \mathrm{F} & \text { degree(s) Fahrenheit } \\ \mathrm{Gy} & \text { gray(s) } \\ \mathrm{h} & \text { hour(s) } \\ \mathrm{in} . & \text { inch(es) } \\ \mathrm{kg} & \text { kilogram(s) } \\ \mathrm{K} & \text { degree(s) Kelvin, kilobyte(s) } \\ \mathrm{km} & \text { kilometer(s) }\end{array}$




$\begin{array}{ll}\mathrm{km}^{2} & \text { square kilometer(s) } \\ \mathrm{L} & \text { liter(s) } \\ \mathrm{lb} & \text { pound(s) } \\ \mathrm{m} & \text { meter(s) } \\ \mathrm{m}^{2} & \text { square meter(s) } \\ \mathrm{m}^{3} & \text { cubic meter(s) } \\ \mathrm{mm} & \text { millimeter(s) } \\ \mu \mathrm{m} & \text { micrometer } \\ \mathrm{MB} & \text { megabyte(s) } \\ \mathrm{min} & \text { minute(s) } \\ \mathrm{mph} & \text { mile(s) per hour } \\ \text { mrem } & \text { millirem(s) } \\ \mathrm{MTHHM} & \text { metric ton(s) of initial heavy metal } \\ \mathrm{MTU} & \text { metric ton(s) of uranium } \\ \mathrm{MW} & \text { megawatt(s) } \\ \mathrm{RBE} & \text { relative biological effectiveness } \\ \mathrm{rad} & \text { radiation absorbed dose(s) } \\ \mathrm{rem} & \text { roentgen-equivalent man } \\ \mathrm{s} & \text { second(s) } \\ \mathrm{s} & \text { second(s) squared } \\ \text { yr } & \text { year(s) }\end{array}$




\title{
RISKIND - A COMPUTER PROGRAM FOR CALCULATING RADIOLOGICAL CONSEQUENCES AND HEALTH RISKS FROM TRANSPORTATION OF SPENT NUCLEAR FUEL
}

by

\author{
Y.C. Yuan, S.Y. Chen, D.J. LePoire, and R. Rothman
}

\begin{abstract}
This report presents the technical details of RISKIND, a computer code designed to estimate potential radiological consequences and health risks to individuals and the collective population from exposures associated with the transportation of spent nuclear fuel. RISKIND is a user-friendly, semiinteractive program that can be run on an IBM or equivalent personal computer. The program language is FORTRAN-77. Several models are included in RISKIND that have been tailored to calculate the exposure to individuals under various incident-free and accident conditions. The incidentfree models assess exposures from both gamma and neutron radiation and can account for different cask designs. The accident models include accidental release, atmospheric transport, and the environmental pathways of radionuclides from spent fuels; these models also assess health risks to individuals and the collective population. The models are supported by databases that are specific to spent nuclear fuels and include a radionuclide inventory and dose conversion factors. The RISKIND code allows for user-specified accident scenarios as well as receptor locations under various exposure conditions, thereby facilitating the estimation of radiological consequences and health risks for individuals. Miedian (50\% probability) and typical worst-case (less than 5\% probability of being exceeded) doses and health consequences from potential accidental releases are calculated by constructing a cumulative dose/probability distribution curve for a complete matrix of site joint-windfrequency data. These consequence results, together with the estimated probability of the entire spectrum of potential accidents, form a comprehensive, prubabilistic risk assessment of a spent nuclear fuel transportation accident.
\end{abstract}




\section{INTRODUCTION}

\subsection{BACKGROUND}

The RISKIND code was developed by the U.S. Department of Energy (DOE) for analyzing radiological consequences and health risks to individuals and the collective population from exposures associated with the transportation of spent nuclear fuel. RISKIND can be used in conjunction with the RADTRAN 4 code (Neuhauser and Kanipe 1992) or its updates and enhanced data modules (Chen et al 1992) to perform a fullscale risk assessment for the transportation of spent nuclear fuel. RADTRAN was originally developed pursuant to the U.S. Nuclear Regulatory Commission (NRC) report Final Environmental Statement on the Transportation of Radioactive Material by Air and Other Modes (NRC 1977b), which was issued to demonstrate compliance with the National Environmental Policy Act (NEPA) of 1969.

The RADTRAN code was designed primarily for estimating the collective population risk from the transportation of radioactive materials under incident-free or accident conditions. The RADTRAN models are not intended to be used for estimating specific risks to individuals in the vicinity of a specific segment of a route.

The risks to individuals or a population subgroup may need to be assessed in situations like the following:

- An individual sitting in his or her car for one hour next to a truck carrying radioactive materials during a traffic jam;

- Individuals in a school or hospital located within $100 \mathrm{~m}$ of a road on which 10 trucks pass per day, six days per week;

- An individual located $500 \mathrm{~m}$ downwind from a rail grade-crossing accident involving a truck carrying spent fuel;

- Individuals within a 2-mi strip of a head-on collision involving a truck carrying spent fuel; 
- An individual ingesting agricultural products that have been contaminated by an accidental release involving a spent nuclear fuel transportation accident; and

- An individual drinking water that has been contaminated by an accidental release near a drinking water supply.

The radiological consequences and health risks from these "what if" situations are of great interest and concern to the public. Specific methods for such scenarios must be used. Calculations for individual doses have been performed previously (Sandquist et al. 1985) and the results used in the environmental assessments (EAs) for three potential repository sites for spent nuclear fuel (DOE 1986a, 1986b, 1986c). However, the approaches used for such calculations were based on somewhat simplified models and assumptions. Substantial databases and technologies relative to the transportation of spent nuclear fuel have since been made available through the efforts of various research organizations. These databases and technologies were used in the development of the RISKIND code.

The RISKIND code has been implemented on the basis of four objectives:

1. The calculation of site- and route-specific radiological consequences and health risks to exposed individuals and the collective local population,

2. The modeling of radiological and environmental pathways to humans ror specific exposure scenarios,

3. The estimation of the source term from potential transportation accident scenarios, and

4. The estimation of cask accident responses specific to the transportation of spent nuclear uel.

To accomplish the first objective, RISKIND has been designed to calculate radiological impacts at specific receptor locations for a variety of exposure scenarios. Comprehensive mathematical models capable of inputting site-specific information at the time of exposure are used; such information includes specific receptor locations, exposure conditions (including individual air and food intake rates), and meteorological conditions. The model used to assess the potential acute health effects from short-term exposures is based on the model developed by Harvard University and the NRC (1989) and the revised 
model of Abrahamson et al. $(1989,1991)$. The dose-to-risk conversion factors for latent health effects are taken from Health Effects of Exposure to Low Levels of Ionizing Radiation, BEIR V (National Research Council 1990) and Publication 60 of the International Commission on Radiological Protection (ICRP 1991).

RISKIND meets the second objective by considering all environmental exposure pathways, including short-term exposure from the initial passing plume, accidental exposure from loss of the cask shield, and long-term exposure from ground depositions and ingestion from the food chain pathways. Pathway analysis has been emphasized for three sensitive environments (each of which represents a unique pathway potential): a major metropolitan area, a productive agricultural area, and a drinking water environment.

To meet the third objective, a radionuclide source inventory was compiled from the database developed by Oak Ridge National Laboratory (ORNL) in which the data are specific to the type of spent fuel (pressurized-water reactor [PWR] or boiling-water reactor [BWR]), cooling times, and burnup rates (NOE 1987b).

To meet the fourth objective, the cask accident responses and the radionuclide release fractions modeled by Lawrence Livermore National Laboratory (LLNL) in its report for the NRC were incorporated into RISKIND. This LLNL/NRC report is commonly referred to as the "NRC modal study" (LLNL 1987).

\subsection{OVERVIEW}

The RISKIND code was developed on the basis of the considerations discussed above. The primary function of the code is the estimation of radiological risk to individuals and to local population subgroups under various environmental settings. The code is designed to be responsive to scenarios associated with transportation (by truck or rail) of spent nuclear fuel. Therefore, the coding approach used in RISKIND emphasizes the descriptions of scenarios, environmental settings, receptor locations, and potential health effects. The code also incorporates the latest available methodologies and databases to facilitate the analysis of radiological risks. Figure 1.1 is a flow diagram of RISKIND showing the radiological risk to an individual from the transportation of spent nuclear fuel.

\footnotetext{
* The database was recently revised (DOE 1992). This revised database will be
} incorporated into RISKIND in the next revision. 


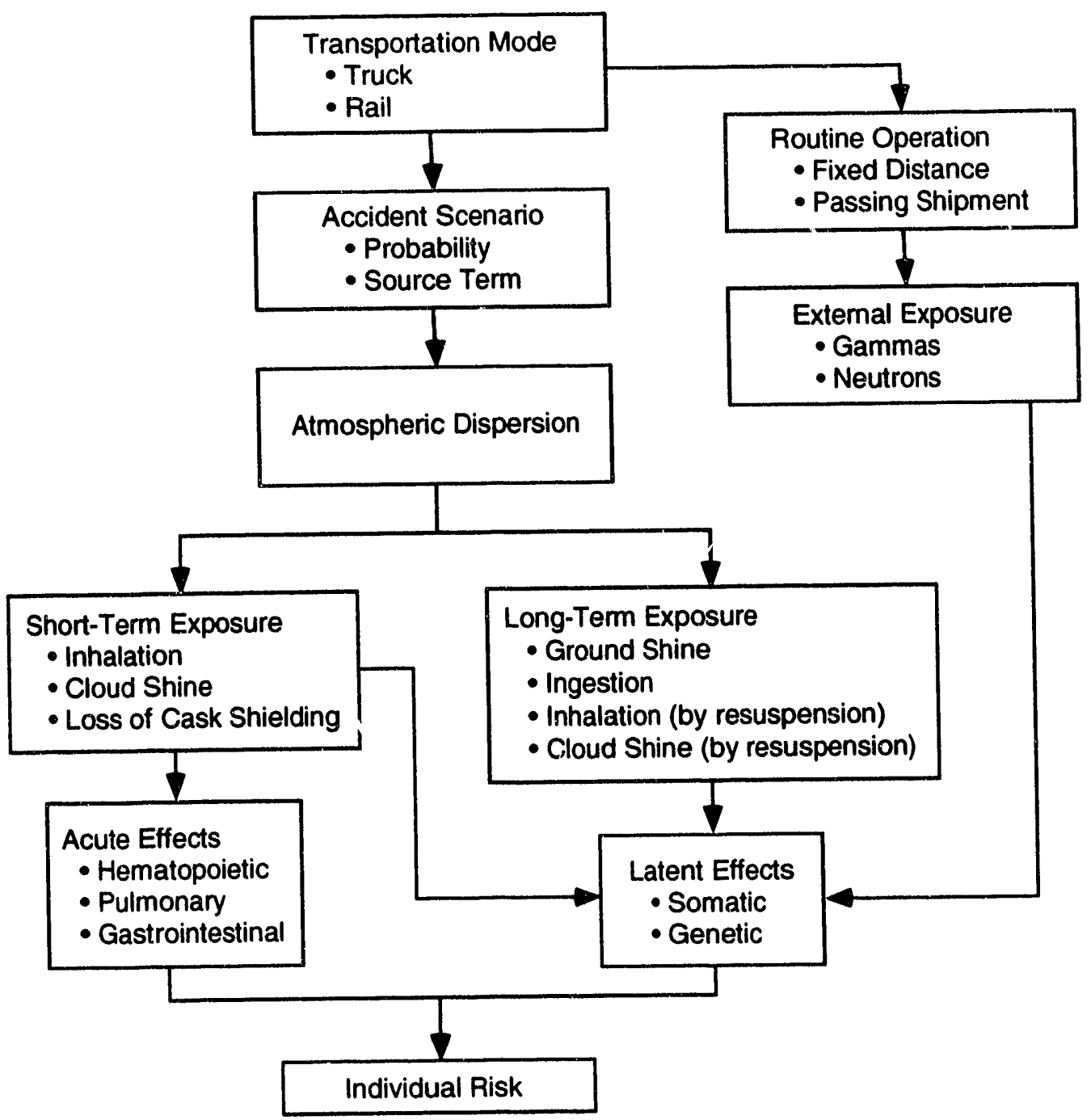

FIGURE 1.1 Flow Diagram of Radiological Risk to an Individual from Transportation of Spent Nuclear Fuel

The radiological risks analyzed by RISKIND include incident-free transportation as well as accident conditions. Exposure from incident-free transportation results solely from the external doses received by individuals from the neutron and gamma radiation emitted from the spent nuclear fuel cask. Under accident conditions, potential exposure to individuals can occur through many environmental pathways if an accident leads to the environmental release of the radioactive contents of the cask. In RISKIND, the estimated exposure, as well as the resulting health effects, is presented individually and for each potential pathway. 
Incident-free exposure includes those occurrences when the transport vehicle is at a stop or in transit. Exposed individuals at a stop may include the vehicle inspector, gas station attendant, passenger at a traffic jam, and so forth; the receptors for the in-transit exposure may include the residents living adjacent to a highway and the passengers sharing the traffic link with the transport vehicle. The model used by RISKIND for predicting external exposure is based on dose rates (Chen and Yuan 1988) derived specifically for a spent fuel cask and takes into account the ground/air scattering of the emitted gammas or neutrons. The model also contains provisions for adjusting the dose rate for changes in cask sizes (i.e., outer radius and length) and provides a realistic, although still somewhat conservative, estimate of the external doses to a receptor.

Under accident conditions, various scenarios have been characterized according to an array of spent nuclear fuel cask responses as described in the NRC's modal study (LLNL 1987). In that study, all accidents are represented by discrete severity modes (i.e., response regions). These response regions range from likely events (with minor ' consequences) tc highly unlikely events (with severe consequences). Twenty response regions are characterized according to two major accident parameters: impact force and thermal force (i.e., heat from fire). Thus, accident conditions would be affected by vehicle speed, object hardness, impact angle and orien ation, and fire location and duration. In the NRC modal study, the bounding case release fractions have also been estimated for each response region. All potential accident scenarios are thus fully represented by the 20 response regions.

To support a consistent and accurate estimate of a release, the spent nuclear fuel radionuclide source inventory is derived from the database developed by ORNL (DOE 1987b). In addition, potential release from crud (i.e., a mixture of reactor coolant corrosion products) spallation is also incorporated. The estimate of crud release is based on a study by Sandia National Laboratories (Sandoval et al. 1991).

The atmospheric transport model of RISKIND includes models that simulate dispersion phenomena resulting from a short release and occurring close to the release. RISKIND's transport model estimates levels of air and ground contamination on the basis of specific meteorological conditions, geometry, and elevation of the release. Plume rise from the thermal buoyancy of a release involving fire is a'so considered. The uncertainty of the effect of weather conditions on the calculated doses is considered by constructing a 
cumulative probability distribution of dose values by using wind-rose data for a given site. This probabilistic dose distribution is then used to determine the "median" (50\% weather probability) and reasonable "maximum" (95\% weather probability) dose values at a given receptor.

The pathway model includes exposure pathways from direct external radiation from the cask (due to loss of shielding), external exposure from the radioactive cloud and ground contamination, and internal exposure from inhalation of radionuclides in the air and potential ingestion of contaminated foods and water.

Health effects to individuals are estimated in terms of chances of acute or latent fatality and in terms of genetic effects from short-term exposure during initial plume passage and long-term exposure originating from deposited radioactive materials. Acute effects are estimated from the latest NRC health effects model (NRC 1989); latent effects are estimated on the basis of the BEIR V Report of the Committee on the Biological Effects of Ionizing Radiation (National Research Council 1990) and ICRP Publication 60 (ICRP 1991).

The consequence model of RISKIND includes provisions for incorporating the consequence-reduction benefits of indoor shielding, evacuation, interdiction of contaminated foods, and other protective actions such as cleanup of contamination to comply with U.S. Environmental Protection Agency (EPA) protective action guide levels (EPA 1991). Consequences can be presented either deterministically (i.e., with fixed accident parameters and weather conditions) or probabilistically (i.e., with variable accident parameters and weather conditions).

The information presented in this report is organized as follows:

- Mathematical models used in RISKIND - Section 2;

- Health effects models used in RISKIND, including descriptions of the acute effects and latent health effects models - Section 3;

- Radionuclide inventory database specific to spent nuclear fuels Appendix A;

- Model for estimating the external dose rates for varying dimensions (radius and length) of the spent nuclear fuel cask - Appendix B; 
- Method for screening the radionuclides that are significant for radiological risk analysis - Appendix C;

- Method for estimating the spallation of crud material during accidents - Appendix D;

- Method for estimating the cask response from user-supplied accident scenarios - Appendix E;

- Program structure and data transfer used in RISKIND - Appendix F;

- Input required to execute RISKIND - Appendix G; and

- Sample problems - Appendix H. 


\section{METHODOLOGY FOR DOSE CALCULATIONS}

The mathematical models used in RISKIND are described in this section. The RISKIND code calculates radiation exposure to an individual or group of individuals (a population subgroup) resulting from the transportation of spent nuclear fuel under both incident-free and accident conditions.

\subsection{RADIOLOGICAL HAZARD FROM INCIDENT-FREE TRANSPORTATION}

\subsubsection{External Dose Model}

In incident-free transportation, individuals are exposed to the direct external radiation emitted from the spent fuel cask. The external dose model is based on two types of radiation, neutron and gamma, the dose rates of which have been modeled from a spent fuel cask (Chen and Yuan 1988). In the external dose model, the dose rates have been calculated separately for neutron and gamma radiation for a specific spent fuel cask configuration (Figure 2.1) that includes air and ground scatterings from the cask. Doses derived from the following approach can be adjusted to accommodate different cask dimensions, according to the method described in Appendix B. The external radiation dose rate $\dot{D}(r)$, expressed in $\mathrm{mrem} / \mathrm{h}$ at a distance $r$ meters from a cask surface, is described by

$$
\dot{D}(r)=\dot{D}_{0}\left[f_{g} R_{g}(r)+f_{n} R_{n}(r)\right]
$$

where:

$$
\begin{aligned}
\dot{\mathrm{D}}_{0}= & \text { total dose rate at } 2 \mathrm{~m} \text { from the outer lateral surface }{ }^{*} \text { of the } \\
& \text { vehicle (i.e., } 10 \mathrm{mrem} / \mathrm{h} \text { if the regulation limit applies); } \\
\mathrm{f}_{\mathrm{g}}, \mathrm{f}_{\mathrm{n}}= & \text { fractions of dose rates emitted from the cask for gamma } \\
& \text { and neutron radiation measured at } 2 \mathrm{~m} \text { from the outer } \\
& \text { lateral surface of the vehicle, } \mathrm{f}_{\mathrm{g}}+\mathrm{f}_{\mathrm{n}}=1.0 \text {; and }
\end{aligned}
$$

* The 10-mrem/h limit at $2 \mathrm{~m}$ is according to the specifications of the Code of Federal Regulations, Title 10, Part 71, and Title 49, Part 173. As a conservative measure, the cask surface is assumed to coincide with the carrier surface. For a more realistic assessment, the user can take the actual carrier dimensions into consideration. 


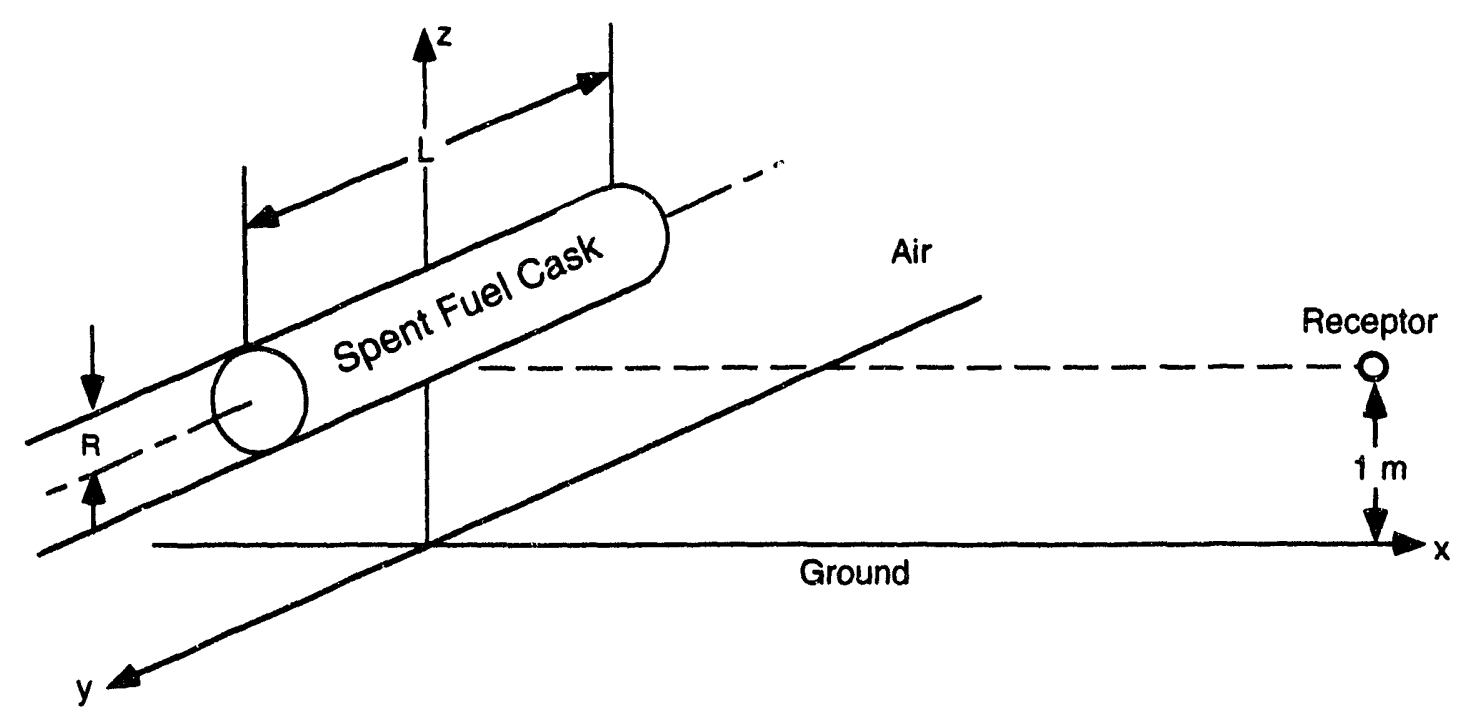

FIGURE 2.1 Configuration of Spent Fuel Cask Relative to the Receptor and Scattering Media (air and ground)

$$
\begin{aligned}
R_{g}(r), R_{n}(r)= & \text { dose rates at a distance } r \text { meters from the cask surface for } \\
& \text { gamma and neutron radiation }(\mathrm{mrem} / \mathrm{h}) \text {, normalized to } 1.0 \\
& \text { at } \mathbf{r}=2 \mathrm{~m} \text { from the outer lateral surface of the vehicle. }
\end{aligned}
$$

All the reference measurement points in Equation 2.1 are assumed to be at $\mathrm{r}=2 \mathrm{~m}$. If the reference point should change, all the parameters in Equation 2.1 should be related to the new reference point where the dose-rate measurement is performed.

The dose rates used in RISKIND were derived from a cask (DOE 1987a) used in assessing radiation doses from the transportation of spent fuel (Chen and Yuan 1988) and are expressed as

$$
\dot{D}(r)=\left\{\begin{array}{c}
A_{0}\left(\frac{1}{r}\right)+A_{1}+A_{2} r, \quad 1 m \leq r \leq 10 m \\
A_{0}\left(\frac{1}{r^{2}}\right)+A_{1}\left(\frac{1}{r}\right)+A_{2}, 10 m<r \leq 2,000 m
\end{array}\right.
$$

* The 10-mrem/h limit at $2 \mathrm{~m}$ is according to the specifications of $10 \mathrm{CFR} 71$ and $49 \mathrm{CFR}$ 173. As a conservative measure, the cask surface is assumed to coincide with the carrier surface. For a more realistic assessment, the user can take the actual carrier dimensions into consideration. 
where $A_{0}, A_{1}$, and $A_{2}$ are fitted coefficients in the applicable range of distances. These coefficients were obtained from statistical dose rates calculated by using the Monte Carlo method and assuming an air/ground environmental setting. A simple $1 / \mathrm{r}^{2}$ relationship is assumed to extrapolate the dose rates for distances exceeding $2,000 \mathrm{~m}$. The dose rates predicted by Equation 2.2 represent the values at the midplane perpendicular to the cask axis. The fitted coefficients are shown in Table 2.1. ${ }^{*}$ In the current derivation, these coefficients are adjusted so that the dose rate $\dot{D}(r)$ is set at a regulatory limit of $10 \mathrm{mrem} / \mathrm{h}$ at $\mathrm{r}=2 \mathrm{~m}$ from the cask surface. When the dose rates are adjusted to meet the regulatory limit, the parameters will be reevaluated to satisfy Equation 2.1 .

\subsubsection{Exposure at Fixed Distances}

For transportation vehicles at stops, radiation exposure concerns are usually limited to persons located at fixed distances from the cask. Such individuals would include truck drivers, train crews, inspectors, escorts, service attendants, and members of the public who are exposed at shipment stops or in traffic jams.

For exposures at fixed distances, the doses to an individual receptor are calculated by

$$
D(r)=\dot{D}_{0}\left[S F_{g} f_{g} R_{g}(r)+S F_{n} f_{n} R_{n}(r)\right] T
$$

where:

$$
\begin{aligned}
\mathrm{D}(\mathrm{r})= & \text { individual dose at distance } \mathrm{r} \text { meters (mrem), } \\
\dot{\mathrm{D}}_{0}= & \text { dose rate of } 10 \mathrm{mrem} / \mathrm{h} \text { at } 2 \mathrm{~m}, \\
\mathrm{SF}_{\mathrm{g}}, \mathrm{SF}_{\mathrm{n}}= & \text { applicable shielding factors for neutron and gamma } \\
& \text { radiation, and } \\
\mathrm{T}= & \text { duration of exposure }(\mathrm{h}) .
\end{aligned}
$$

The parameters $f_{g}, f_{n}, R_{g}(r)$, and $R_{n}(r)$ are defined in Equation 2.1.

* The coefficients in Table 2.1 have been normalized to $10 \mathrm{mrem} / \mathrm{h}$ at $1 \mathrm{~m}$; they are renormalized at $2 \mathrm{~m}$ for the ensuing derivations. 
TABLE 2.1 Coefficients of the Fitted Equations for Neutron and Gamma Dose Rates from a Spent Fuel Cask, with Groundscattering

\begin{tabular}{|c|c|c|c|c|}
\hline \multirow[b]{2}{*}{$\begin{array}{l}\text { Segment } \\
\text { No. }\end{array}$} & \multirow{2}{*}{$\begin{array}{c}\text { Distance from } \\
\text { Cask Surface, } r(\mathrm{~m})\end{array}$} & \multicolumn{3}{|c|}{ Neutron Coefficients } \\
\hline & & $\mathrm{A}_{0}$ & $\mathrm{~A}_{1}$ & $\mathrm{~A}_{2}$ \\
\hline 1 & $1-5$ & 9.15955 & 1.12880 & $-2.88350 \times 10^{-1}$ \\
\hline 2 & $5-10$ & $1.44796 \times 10^{1}$ & -1.92540 & $8.76461 \times 10^{-2}$ \\
\hline 3 & $10-50$ & $1.43305 \times 10^{1}$ & 2.86620 & $-4.32586 \times 10^{-2}$ \\
\hline 4 & $50-100$ & $6.53338 \times 10^{1}$ & $-3.89107 \times 10^{-1}$ & $1.44725 \times 10^{-3}$ \\
\hline 5 & $100-400$ & $6.31707 \times 10^{1}$ & $-2.23367 \times 10^{-1}$ & $2.14649 \times 10^{-4}$ \\
\hline 6 & $400-700$ & $3.31005 \times 10^{1}$ & $-8.77733 \times 10^{-2}$ & $6.10026 \times 10^{-5}$ \\
\hline 7 & $700-1000$ & $1.23630 \times 10^{1}$ & $-2.34070 \times 10^{-2}$ & $1.13044 \times 10^{-5}$ \\
\hline 8 & $1,000-2,000$ & 1.17000 & $-1.23900 \times 10^{-3}$ & $3.29000 \times 10^{-7}$ \\
\hline \multirow[b]{2}{*}{$\begin{array}{l}\text { Segment } \\
\text { No. }\end{array}$} & \multirow[b]{2}{*}{$\begin{array}{c}\text { Distance from } \\
\text { Cask Surface, } \mathbf{r}(\mathrm{m})\end{array}$} & \multicolumn{3}{|c|}{ Gamma Coefficients } \\
\hline & & $\mathrm{A}_{0}$ & $\mathbf{A}_{1}$ & $\mathrm{~A}_{2}$ \\
\hline 1 & 1.5 & $1.01839 \times 10^{1}$ & $-3.59449 \times 10^{-2}$ & $-1.48173 \times 10^{-1}$ \\
\hline 2 & $5-10$ & $1.03586 \times 10^{1}$ & $-9.70747 \times 10^{-1}$ & $3.18380 \times 10^{-2}$ \\
\hline 3 & $10-50$ & $3.79031 \times 10^{1}$ & $1.09056 \times 10^{-1}$ & $-2.44353 \times 10^{-3}$ \\
\hline 4 & $50-100$ & $4.41139 \times 10^{1}$ & $-1.80979 \times 10^{-1}$ & $1.83778 \times 10^{-4}$ \\
\hline 5 & $100-200$ & $5.14981 \times 10^{1}$ & $-3.03029 \times 10^{-1}$ & $6.65919 \times 10^{-4}$ \\
\hline 6 & $200-500$ & $3.23906 \times 10^{1}$ & $-8.56746 \times 10^{-2}$ & $5.68388 \times 10^{-5}$ \\
\hline 7 & $500-1,000$ & $1.50277 \times 10^{1}$ & $-3.03719 \times 10^{-2}$ & $1.55808 \times 10^{-5}$ \\
\hline 8 & $1,000-2,000$ & $8.70000 \times 10^{1}$ & $-8.38610 \times 10^{-4}$ & $2.05600 \times 10^{-7}$ \\
\hline
\end{tabular}

Note: The dose rate is normalized to $10 \mathrm{mrem} / \mathrm{h}$ at $1 \mathrm{~m}$ from the cask surface.

Equations for dose rates in $\mathrm{mrem} / \mathrm{h}$ are expressed by

$$
\begin{aligned}
& \dot{D}(r)=A_{0} \frac{1}{r}+A_{1}+A_{2} r(\text { for } 1 m \leq r \leq 10 m), \text { and } \\
& \dot{D}(r)=A_{0} \frac{1}{r^{2}}+A_{1} \frac{1}{r}+A_{2}(\text { for } 10 m \leq r \leq 2,000 m)
\end{aligned}
$$

Source: Chen and Yuan (1988); data for $1,000 \mathrm{~m}<\mathrm{r} \leq 2,000 \mathrm{~m}$ were obtained by using the same methodology. Extrapolation beyond $2,000 \mathrm{~m}$ is assumed to follow the $1 / \mathrm{r}^{2}$ relationship. 
For exposure to a population subgroup under this exposure scenario, the population dose is estimated by

$$
\mathrm{D}_{\mathrm{p}}=\mathrm{N}_{\mathrm{p}} \dot{\mathrm{D}}\left(\mathrm{r}_{0}\right) \mathrm{T}
$$

where:

$$
\begin{aligned}
D_{p} & =\text { population dose for population subgroup } p \text { (person-mrem), } \\
N_{p} & =\text { number of exposed persons in population subgroup } p \\
r_{0} & =\text { exposure distance }(m), \text { and } \\
T & =\text { duration of exposure }(h)
\end{aligned}
$$

For exposure to members of the public, such as at shipment stops, the population density is assumed to be uniform within two concentric circles (representing minimum and maximum distances) around the cask. In this situation, the population dose is estimated by

$$
D_{s}=2 \pi P D T \int_{r_{1}}^{r_{2}} D(r) r d r
$$

where:

$$
\begin{aligned}
D_{s} & =\text { population dose at stops (person-mrem), } \\
\mathrm{PD} & =\text { population density at stops }\left(\text { person } / \mathrm{m}^{2}\right), \\
\mathrm{T} & =\text { duration of exposure }(\mathrm{h}), \\
\mathrm{r}_{1} & =\text { minimum exposure distance }(\mathrm{m}), \text { and } \\
\mathrm{r}_{2} & =\text { maximum exposure distance }(\mathrm{m}) .
\end{aligned}
$$

\subsubsection{Exposure from a Passing Shipment}

As a shipment vehicle passes by, an off-link individual will experience a changing exposure field that is dictated by the constantly changing distance between the moving equipment and the individual, as shown in Figure 2.2. Calculation of doses to a specific population group is according to Equation 2.5. The parameters shown in Figure 2.2 are used to define the appropriate population zones needed for Equation 2.5. It is possible to derive 


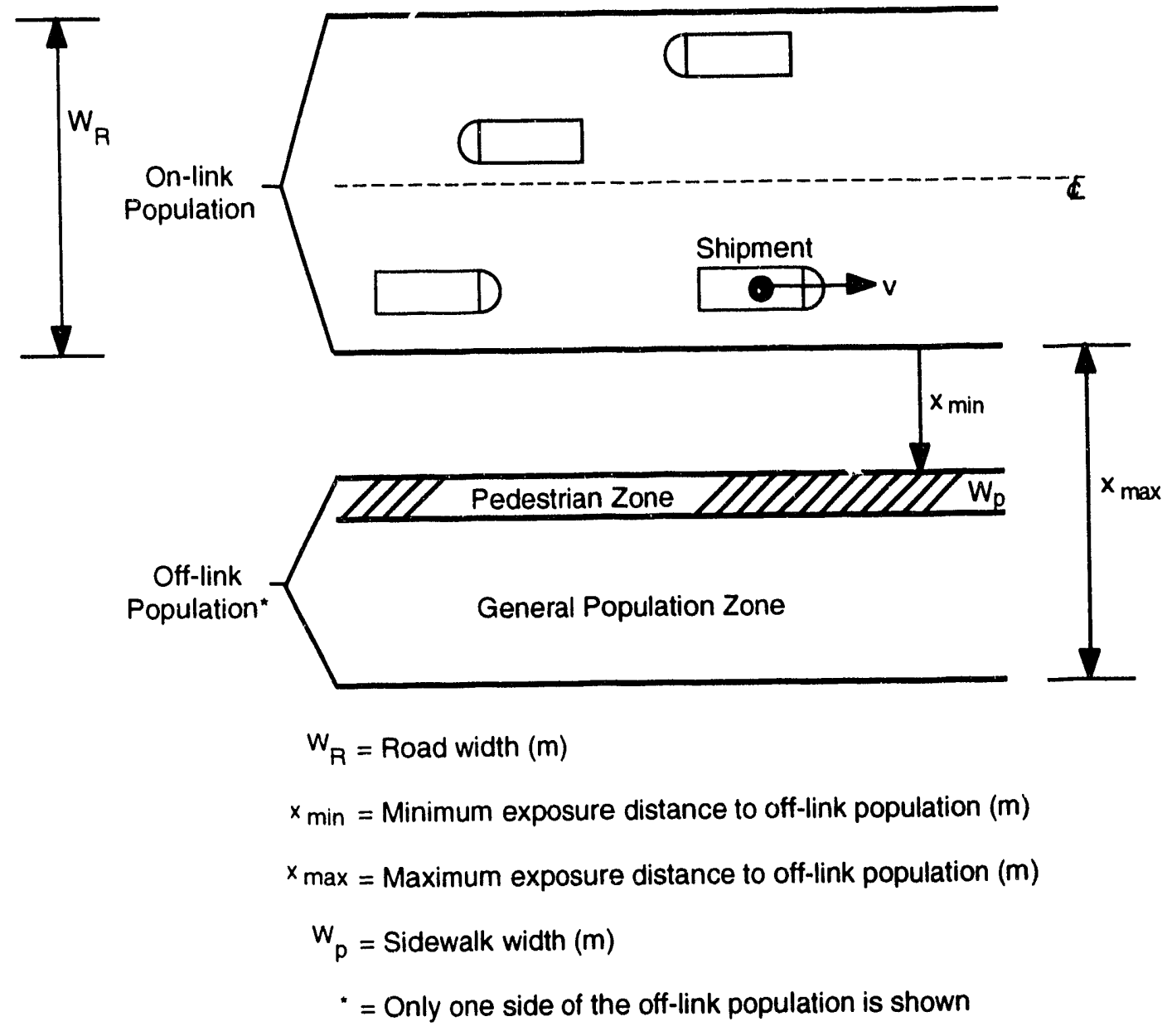

FIGURE 2.2 Schematic Diagram of External Exposures to Various Population Groups from a Moving Shipment of Spent Fuel Casks

the mathematical relationship of the locations and distances between the moving shipment and the receptor under such conditions. The total dose $D(x)$ received by an individual at a distance $\mathbf{x}$ from the passing shipment is calculated by the integration of the dose rate $\dot{D}(\mathbf{r})$ over the total exposure period:

$$
\mathrm{D}(\mathbf{x})=2 \int_{t=0}^{\infty} \dot{\mathrm{D}}(\mathbf{r}) \mathrm{dt}
$$

From the relationship $y=v t$ (speed $\times$ traveling time), Equation 2.6 becomes

$$
\mathrm{D}(\mathrm{x})=\mathrm{K}_{0} \frac{2}{\mathrm{v}} \int_{0}^{\infty} \dot{\mathrm{D}}(\mathrm{r}) \mathrm{dy}
$$

where:

$\mathrm{D}(\mathbf{x})=$ total dose (mrem) to the receptor at distance $\mathbf{x}$; 


$$
\begin{aligned}
\mathrm{K}_{0} & =\text { unit conversion constant }\left(10^{-3} \mathrm{~km} / \mathrm{m}\right) \\
v & =\text { vehicle speed }(\mathrm{km} / \mathrm{h}) \\
r & =\left(\mathrm{x}^{2}+\mathrm{y}^{2}\right)^{1 / 2}, \mathrm{r}(\mathrm{m}) ; \text { and } \\
\mathrm{dy} & =\mathrm{vdt}, \text { the distance for traveling time } \mathrm{dt}(\mathrm{m}) .
\end{aligned}
$$

Equation 2.7 can be expressed by

$$
\mathrm{D}(\mathrm{x})=\mathrm{K}_{0} \frac{2}{\mathrm{v}} \mathrm{I}(\mathrm{x})
$$

where:

$$
I(x)=\int_{x}^{\infty} \dot{D}(r) \frac{r}{\left(r^{2}-x^{2}\right)^{1 / 2}} d r
$$

The term $\mathrm{x}$ is the distance $(\mathrm{m})$ between the route and the receptor.

To estimate the off-link population dose per unit of travel distance from the passing vehicle, a uniform population density between exposure distances $x_{1}$ and $x_{2}$ is assumed:

$$
\mathrm{D}_{\mathrm{OL}}=\mathrm{PD} \mathrm{K}_{0} \frac{2}{\mathrm{v}} \int_{\mathrm{x}_{1}}^{\mathrm{x}_{2}} \mathrm{I}(\mathrm{x}) \mathrm{dx}
$$

where:

$$
\begin{aligned}
& \mathrm{D}_{\mathrm{OL}}=\text { population dose (person-mrem) per meter of travel distance, and } \\
& \mathrm{PD}=\text { population density }\left(\text { persons } / \mathrm{m}^{2}\right. \text { ). }
\end{aligned}
$$

\subsubsection{Cask Dimensions and Other Key Parameters}

The cask dimensions (i.e., radius and length) are adjusted on the basis of reference (truck) cask dimensions for PWRs; adjustments have been made for dose rates (Appendix B). Similar adjustments can be made for casks with different dimensions. The reference cask is based on the preliminary designs of DOE's Initiative I GA-4 truck cask for PWRs; GA-9 truck cask (General Atomics 1990) for BWRs; and BR-100, a 100-ton rail/barge cask for both PWRs and BWRs (Babcock and Wilcox 1990). Some of the basic design characteristics are 
shown in Table 2.2, which compares DOE Initiative I casks with those used in the NRC modal study (LLNL 1987). The model's output consists of a dose table containing dose parameters versus distances from the cask. Table 2.3 provides the sample dose information versus distance for a PWR (GA-4 design) truck cask.

\subsection{RADIOLOGICAL HAZARD FROM ACCIDENTS}

The fuel assemblies used in commercial power reactors contain solid ceramic uranium oxide $\left(\mathrm{UO}_{2}\right)$ fuel pellets. During reactor operation, the fissions of uranium fuel create radioactive fission and activation products. Physically, most of the radioactive material remains in solid form within the pellets, although the pellets may exhibit some degree of fracturing. A small fraction of the fission products, however, is in gaseous or volatile form. The radiological hazards that could conceivably be created by this material can occur through two distinct cask-damage mechanisms: (1) a release of material from a damaged cask or (2) an increase in the external radiation level emanating from material within the cask. Material releases can occur in gaseous, volatile, or solid form. Solid particles that could be inhaled can pose a significant hazard to humans. Increased radiation levels from material still within the cask could occur as the result of voids in the cask shielding, which can result from mechanical forces or temperatures high enough to cause shield materials to melt. The methods used to assess these potential radiological hazards are described in the following sections. Section 2.2.1 describes the cask accident response and release model, and Section 2.2.2 presents the dose calculation model for individuals; the dose model for the collective local population is presented in Section 2.2.3. The cask response and release model follows that of the NRC modal study (LLNL 1987); the individual dose model is similar to that of the AI-RISK code (Yuan and MacFarlane 1992); and the population dose model has been developed specifically for RISKIND applications.

\subsubsection{Accident Response and Release Model}

\subsubsection{Cask Response}

The responses of spent nuclear fuel casks under a range of highway and railway accident conditions have been investigated by LLNL for the NRC. The results of this study 
TABLE 2.2 Comparison of Preliminary Design Characteristics of DOE Initiative I and 2JRC Modal Study Spent Nuclear Fuel Transportation Casks

\begin{tabular}{|c|c|c|c|c|c|c|}
\hline Cask Type & $\begin{array}{c}\text { GA-4 } \\
\text { Cask } \\
\text { (truck) }\end{array}$ & $\begin{array}{c}\text { GA-9 } \\
\text { Cask } \\
\text { (truck) }\end{array}$ & $\begin{array}{c}\text { BR-100 } \\
\text { Cask } \\
\text { (rail/ } \\
\text { barge) }\end{array}$ & $\begin{array}{c}\text { BR-100 } \\
\text { Cask } \\
\text { (raiV } \\
\text { barge) }\end{array}$ & $\begin{array}{l}\text { NRC } \\
\text { Modal } \\
\text { Study } \\
\text { (truck) }\end{array}$ & $\begin{array}{l}\text { NRC } \\
\text { Modal } \\
\text { Study } \\
\text { (rail) }\end{array}$ \\
\hline Fuel type & PWR & BWR & PWR & BWR & PWR & PWR \\
\hline Number of fuel assemblies & 4 & 9 & 21 & 52 & 1 & 21 \\
\hline $\begin{array}{l}\text { Initial uranium weight } \\
\text { (MTU/cask) }\end{array}$ & 1.69 & 1.59 & 8.89 & 9.19 & 0.46 & 8.89 \\
\hline Length (m) & 4.77 & 5.03 & 5.13 & 5.13 & 6.93 & 6.93 \\
\hline Radius (cm) & 50.48 & 50.48 & 104.1 & 104.1 & 46.4 & 109 \\
\hline Fuel burnup (MWd/MTU) & 35,000 & 30,000 & 35,000 & 30,000 & 33,000 & 33,000 \\
\hline Cooling time (yr) & 10 & 10 & 10 & 10 & 5 & 5 \\
\hline $\begin{array}{l}\text { Maximum initial enrichment } \\
\text { (wt\% uranium-235) }\end{array}$ & 4.5 & 4.5 & 4.5 & 4.5 & b & - \\
\hline Fraction of gamma radiation ${ }^{a}$ & 0.83 & 0.83 & 0.60 & 0.48 & - & - \\
\hline Fraction of neutron radiation ${ }^{a}$ & 0.17 & 0.17 & 0.40 & 0.52 & - & - \\
\hline
\end{tabular}

Dose rate fractions estimated at $2 \mathrm{~m}$ from the centerline of the casks.

b A hyphen indicates that data are not available.

Sources: General Atomics (1990), Babcock and Wilcox (1990), and LLNL (1987).

are provided in detail in the NRC modal study (LLNL 1987). In the NRC modal study, all potential damages to a shipping cask during an accident are categorized according to two principal variables: the cask structural response and the thermal response induced by cask impact and fire, respectively. Twenty cask response regions (or categories) based on varying levels of cask strain and temperature are categorized to represent the entire specirum of transportation ascidents. These cask response legions and the probabilities of occurrence for combined nechanical and thermal loads should an accident occur are shown in Figure 2.3. 
TABLE 2.3 Sample of External Dose Information Based on DOE's Initiative I GA-4 Truck Cask ${ }^{a, b}$ for a PWR

\begin{tabular}{|c|c|c|c|c|c|}
\hline Interval & $\begin{array}{c}\text { Distance } \\
(\mathrm{m})\end{array}$ & $\begin{array}{c}\text { Dose Rate, } \\
\text { D } \\
(\mathrm{mrem} / \mathrm{h})\end{array}$ & $\begin{array}{c}\text { Dose from } \\
\text { Passing } \\
\text { Shipment, D } \\
\text { (mrem) }\end{array}$ & $\begin{array}{c}\text { Population } \\
\text { Dose at } \\
\text { Stops D } \\
\text { (person- } \\
\text { mrem/h) } \\
\end{array}$ & $\begin{array}{c}\text { Off-Link } \\
\text { Population } \\
\text { Dose, } \mathrm{D}_{\mathrm{OL}} \\
(\text { person- } \\
\mathrm{mrem} / \mathbf{k m})^{\mathrm{c}}\end{array}$ \\
\hline 1 & 1.00 & $2.13 \times 10^{1}$ & $1.13 \times 10^{-1}$ & 0.0 & 0.0 \\
\hline 2 & 2.00 & $1.00 \times 10^{1}$ & $8.28 \times 10^{-2}$ & $1.30 \times 10^{-4}$ & $9.80 \times 10^{-5}$ \\
\hline 3 & 3.00 & 6.01 & $6.43 \times 10^{-2}$ & $2.50 \times 10^{-4}$ & $1.72 \times 10^{-4}$ \\
\hline 4 & 4.00 & 3.89 & $5.10 \times 10^{-2}$ & $3.55 \times 10^{-4}$ & $2.29 \times 10^{-4}$ \\
\hline 5 & 5.00 & 2.52 & $4.11 \times 10^{-2}$ & $4.42 \times 10^{-4}$ & $2.75 \times 10^{-4}$ \\
\hline 6 & 6.00 & 1.82 & $3.51 \times 10^{-2}$ & $5.15 \times 10^{-4}$ & $3.13 \times 10^{-4}$ \\
\hline 7 & 7.00 & 1.38 & $3.05 \times 10^{-2}$ & $5.79 \times 10^{-4}$ & $3.46 \times 10^{-4}$ \\
\hline 8 & 8.00 & 1.08 & $2.68 \times 10^{-2}$ & $6.37 \times 10^{-4}$ & $3.75 \times 10^{-4}$ \\
\hline 9 & 9.00 & $8.64 \times 10^{-1}$ & $2.39 \times 10^{-2}$ & $6.88 \times 10^{-4}$ & $4.00 \times 10^{-4}$ \\
\hline 10 & $1.00 \times 10^{1}$ & $7.09 \times 10^{-1}$ & $2.14 \times 10^{-2}$ & $7.34 \times 10^{-4}$ & $4.23 \times 10^{-4}$ \\
\hline 11 & $1.20 \times 10^{1}$ & $4.99 \times 10^{-1}$ & $1.78 \times 10^{-2}$ & $8.57 \times 10^{-4}$ & $5.62 \times 10^{-4}$ \\
\hline 12 & $1.40 \times 10^{1}$ & $3.71 \times 10^{-1}$ & $1.53 \times 10^{-2}$ & $9.27 \times 10^{-4}$ & $4.95 \times 10^{-4}$ \\
\hline 13 & $1.60 \times 10^{1}$ & $2.87 \times 10^{-1}$ & $1.33 \times 10^{-2}$ & $9.88 \times 10^{-3}$ & $5.24 \times 10^{-4}$ \\
\hline 14 & $1.80 \times 10^{1}$ & $2.29 \times 10^{-1}$ & $1.18 \times 10^{-2}$ & $1.04 \times 10^{-3}$ & $5.49 \times 10^{-4}$ \\
\hline 15 & $2.00 \times 10^{1}$ & $1.87 \times 10^{-1}$ & $1.05 \times 10^{-2}$ & $1.09 \times 10^{-3}$ & $5.71 \times 10^{-4}$ \\
\hline 16 & $2.50 \times 10^{1}$ & $1.21 \times 10^{-1}$ & $8.19 \times 10^{-3}$ & $1.20 \times 10^{-3}$ & $6.18 \times 10^{-4}$ \\
\hline 17 & $3.00 \times 10^{1}$ & $8.44 \times 10^{-2}$ & $6.60 \times 10^{-3}$ & $1.28 \times 10^{-3}$ & $6.55 \times 10^{-4}$ \\
\hline 18 & $3.50 \times 10^{1}$ & $6.16 \times 10^{-2}$ & $5.43 \times 10^{-3}$ & $1.35 \times 10^{-3}$ & $6.85 \times 10-4$ \\
\hline 19 & $4.00 \times 10^{1}$ & $4.64 \times 10^{-2}$ & $4.53 \times 10^{-3}$ & $1.42 \times 10^{-3}$ & $7.10 \times 10^{-4}$ \\
\hline 20 & $4.50 \times 10^{1}$ & $3.57 \times 10^{-2}$ & $3.83 \times 10^{-3}$ & $1.47 \times 10^{-3}$ & $7.31 \times 10^{-4}$ \\
\hline 21 & $5.00 \times 10^{1}$ & $2.77 \times 10^{-2}$ & $3.25 \times 10^{-3}$ & $1.52 \times 10^{-3}$ & $7.48 \times 10^{-4}$ \\
\hline 22 & $6.00 \times 10^{1}$ & $1.77 \times 10^{-2}$ & $2.51 \times 10^{-3}$ & $1.59 \times 10^{-3}$ & $7.77 \times 10^{-4}$ \\
\hline 23 & $7.00 \times 10^{1}$ & $1.24 \times 10^{-2}$ & $2.00 \times 10^{-3}$ & $1.65 \times 10^{-3}$ & $8.00 \times 10^{-4}$ \\
\hline 24 & $8.00 \times 10^{1}$ & $9.04 \times 10^{-2}$ & $1.63 \times 10^{-3}$ & $1.70 \times 10^{-3}$ & $8.18 \times 10^{-4}$ \\
\hline 25 & $9.00 \times 10^{1}$ & $6.82 \times 10^{-3}$ & $1.35 \times 10^{-3}$ & $1.74 \times 10^{-3}$ & $8.33 \times 10^{-4}$ \\
\hline 26 & $1.00 \times 10^{2}$ & $5.27 \times 10^{-3}$ & $1.13 \times 10^{-3}$ & $1.78 \times 10^{-3}$ & $8.45 \times 10^{-4}$ \\
\hline 27 & $2.00 \times 10^{2}$ & $8.37 \times 10^{-4}$ & $3.06 \times 10^{-4}$ & $1.96 \times 10^{-3}$ & $9.17 \times 10^{-4}$ \\
\hline 28 & $3.00 \times 10^{2}$ & $2.41 \times 10^{-4}$ & $1.12 \times 10^{-4}$ & $2.04 \times 10^{-3}$ & $9.38 \times 10^{-4}$ \\
\hline 29 & $4.00 \times 10^{2}$ & $8.04 \times 10^{-5}$ & $4.36 \times 10^{-5}$ & $2.07 \times 10^{-3}$ & $9.46 \times 10^{-4}$ \\
\hline 30 & $5.00 \times 10^{2}$ & $2.71 \times 10^{-5}$ & $1.79 \times 10^{-5}$ & $2.08 \times 10^{-3}$ & $9.49 \times 10^{-4}$ \\
\hline 31 & $6.00 \times 10^{2}$ & $1.17 \times 10^{-5}$ & $8.40 \times 10^{-6}$ & $2.09 \times 10^{-3}$ & $9.50 \times 10^{-4}$ \\
\hline 32 & $7.00 \times 10^{2}$ & $5.08 \times 10^{-6}$ & $3.87 \times 10^{-6}$ & $2.09 \times 10^{-3}$ & $9.51 \times 10^{-4}$ \\
\hline 33 & $8.00 \times 10^{2}$ & $1.99 \times 10^{-6}$ & $1.72 \times 10^{-6}$ & $2.09 \times 10^{-3}$ & $1.06 \times 10^{-4}$ \\
\hline 34 & $9.00 \times 10^{2}$ & $7.26 \times 10^{-7}$ & $8.58 \times 10^{-7}$ & $2.09 \times 10^{-3}$ & $1.06 \times 10^{-4}$ \\
\hline 35 & $1.00 \times 10^{3}$ & $4.19 \times 10^{-7}$ & $5.93 \times 10^{-7}$ & $2.09 \times 10^{-3}$ & $1.06 \times 10^{-4}$ \\
\hline 36 & $1.10 \times 10^{3}$ & $2.84 \times 10^{-7}$ & $4.21 \times 10^{-7}$ & $2.09 \times 10^{-3}$ & $1.06 \times 10^{-4}$ \\
\hline 37 & $1.20 \times 10^{3}$ & $1.93 \times 10^{-7}$ & $2.97 \times 10^{-7}$ & $2.09 \times 10^{-3}$ & $1.06 \times 10^{-4}$ \\
\hline 38 & $1.30 \times 10^{3}$ & $1.29 \times 10^{-7}$ & $2.10 \times 10^{-7}$ & $2.09 \times 10^{-3}$ & $1.06 \times 10^{-4}$ \\
\hline 39 & $1.40 \times 10^{3}$ & $8.52 \times 10^{-8}$ & $1.48 \times 10^{-7}$ & $2.09 \times 10^{-3}$ & $1.06 \times 10^{-4}$ \\
\hline 40 & $1.50 \times 10^{3}$ & $5.49 \times 10^{-8}$ & $1.05 \times 10^{-7}$ & $2.09 \times 10^{-3}$ & $1.06 \times 10^{-4}$ \\
\hline 41 & $2.00 \times 10^{3}$ & $6.07 \times 10^{-9}$ & $3.82 \times 10^{-8}$ & $2.09 \times 10^{-3}$ & $1.06 \times 10^{-4}$ \\
\hline 42 & $3.00 \times 10^{3}$ & $2.72 \times 10^{-9}$ & $2.54 \times 10^{-8}$ & $2.09 \times 10^{-3}$ & $1.09 \times 10^{-4}$ \\
\hline
\end{tabular}


TABLE 2.3 (Cont.)

\begin{tabular}{|c|c|c|c|c|c|}
\hline Interval & $\begin{array}{c}\text { Distance } \\
(\mathrm{m})\end{array}$ & $\begin{array}{c}\text { Dose Rate, } \\
\dot{\mathbf{D}} \\
(\mathrm{mrem} / \mathrm{h})\end{array}$ & $\begin{array}{l}\text { Dose from } \\
\text { Passing } \\
\text { Shipment, D } \\
\text { (mrem) }\end{array}$ & $\begin{array}{c}\text { Population } \\
\text { Dose at } \\
\text { Stops } D_{s} \\
\text { (person- } \\
\text { mrem } / \mathrm{h} \text { ) }\end{array}$ & $\begin{array}{c}\text { Off-Link } \\
\text { Population } \\
\text { Dose, } D_{\text {OL }} \\
(\text { person- } \\
\text { mrem } / \mathrm{km})^{\mathrm{c}}\end{array}$ \\
\hline $\begin{array}{l}43 \\
44 \\
45\end{array}$ & $\begin{array}{l}4.00 \times 10^{3} \\
5.00 \times 10^{3} \\
1.00 \times 10^{4}\end{array}$ & $\begin{array}{l}1.52 \times 10^{-9} \\
9.75 \times 10^{-10} \\
2.43 \times 10^{-10}\end{array}$ & $\begin{array}{l}1.91 \times 10^{-8} \\
1.53 \times 10^{-8} \\
7.63 \times 10^{-9}\end{array}$ & $\begin{array}{l}2.09 \times 10^{-3} \\
2.09 \times 10^{-3} \\
2.09 \times 10^{-3}\end{array}$ & $\begin{array}{l}9.51 \times 10^{-4} \\
9.51 \times 10^{-4} \\
9.51 \times 10^{-4}\end{array}$ \\
\hline
\end{tabular}

a It is assumed that the fraction of the gamma dose $\left(f_{g}\right)$ is equal to 0.83 , that the fraction of the neutron dose $\left(f_{n}\right)$ is equal to 0.17 , and that the shielding factor is equal to 1 . The dose rate is assumed to be the regulatory limit, that is, $10 \mathrm{mrem} / \mathrm{h}$ at $2 \mathrm{~m}$ from the surface of a GA-4 truck cask.

b The dose information contains $\dot{D}=$ dose rate (Equation 2.1 ), $D=$ dose from passing vehicle (Equation 2.8), $\mathrm{D}_{\mathrm{s}_{2}}=$ population dose at stops (Equation 2.4) for population density of 1 person $/ \mathrm{km}^{2}$, and $\mathrm{D}_{\mathrm{OL}}=$ off-link population dose (Equation 2.9) for population density of 1 person $/ \mathrm{km}^{2}$. The vehicle speed $(V)$ is assumed to be $1 \mathrm{~km} / \mathrm{h}$.

c The population dose represents the dose to the population on one side of the road adjacent to the vehicle.

The most important accident conditions used to define the mechanical loads imposed on a cask during an accident are those associated with various impacts. Because of the large weight, hardness, and rigidity of spent fuel casks, loads caused by crushing, projectiles, or other mechanisms have been demonstrated to be far less damaging than loads caused by impacts with hard, massive objects. As in any impact involving a motor vehicle or train, the damage sustained would depend on vehicle speed, angle of impact, hardness and massiveness of the object struck, and orientation of the vehicle or object at the time of impact. The temperature of an accident-generated fire is the most important consideration in assessing potential cask functional degradation. The cumulative heat affecting a cask depends not only on the temperature and duration of the fire but also on the extent to which the cask is exposed. Data on fire temperatures and durations are not readily available in accident records; however, conservative estimates of fire temperatures and duration can be calculated on the basis of pertinent information about the accident, such as the maximum fuel volume carried by a typical tank truck and the nature of the product being shipped. Another 


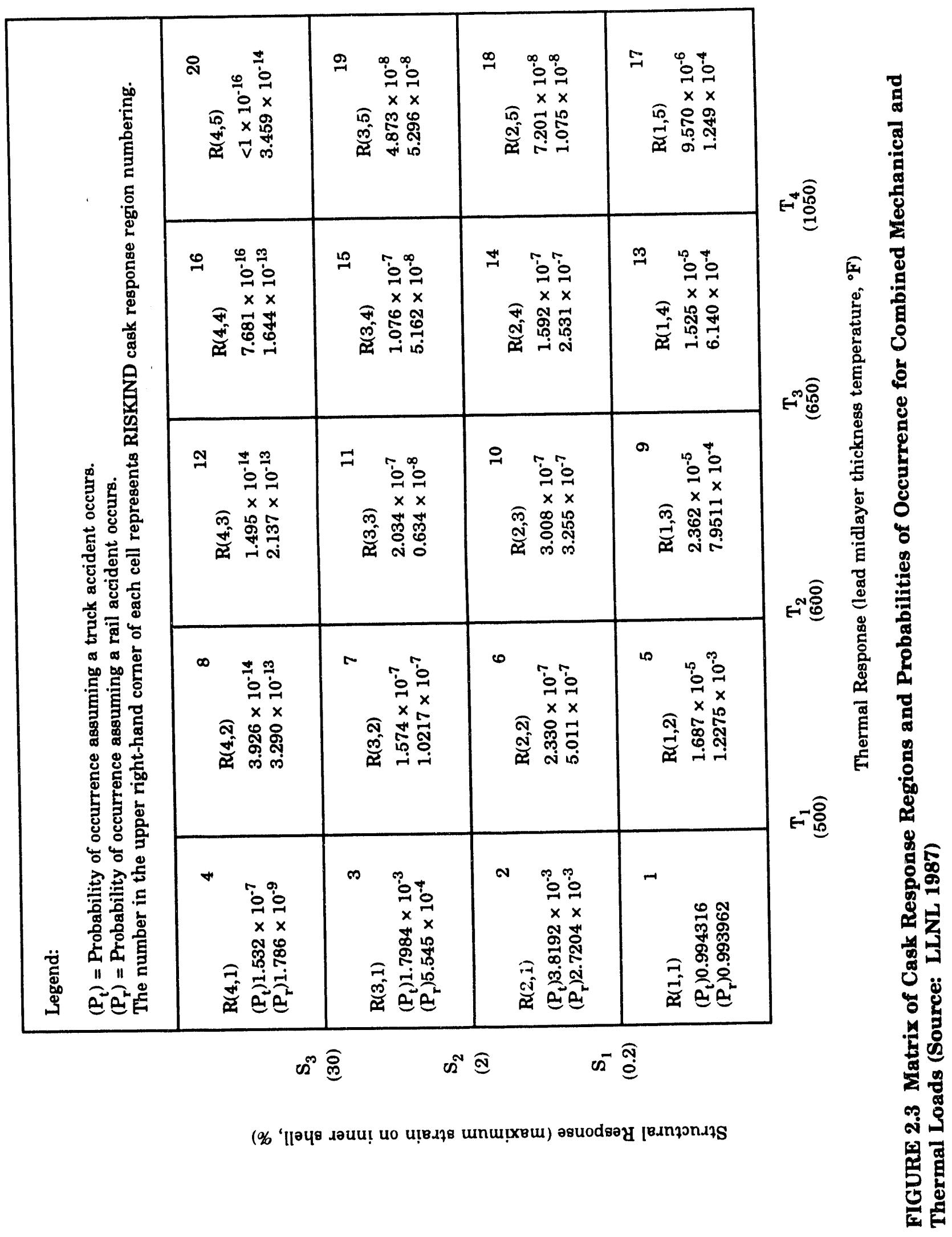


accident condition required to describe cask response is the relative location of a cask to the fire during an accident. Appendix E presents the method used in RISKIND for estimating the cask response from user-supplied accident scenarios. Stammer et al. (1990) have characterized accident events on the basis of actual or potential situations that result in levels of structural and thermal response such that at least one event is defined for each of the 20 response regions in the matrix in Figure 2.3. The NRC (Lahs 1987) has also provided the predicted cask response to a number of selected historical accident events.

\subsubsection{Release Fractions}

According to the NRC modal study (LLNL 1987), three mechanisms are necessary for establishing a release path from the spent fuel to the environment: (1) diffusion from cracked fuel pellets, (2) a leak from a breach of the fuel rod cladding, and (3) a leak through deteriorated cask seals. Before radioactive material is released into the cask cavity, the cladding must be breached during an accident. A fuel rod's cladding can be breached as a result of high impact or high temperature. The percentage of fuel rods that can be breached by high impact and fires in a transportation accident is estimated in the NRC modal study. After a rod is breached, radioactive gases, volatiles, and solids can potentially escape into the cask cavity. Only rod burst and oxidation were considered significant release mechanisms in the NRC modal study. It was conservatively assumed that all the released materials in the cask cavity would be released to the environment if a leak path developed in the containment. A leak path is assumed to occur for any transportation accident resulting in a maximum strain in the inner containment shell greater than $0.2 \%$, or in a lead midlayer thickness temperature exceeding $500^{\circ} \mathrm{F}$.

On the basis of the above assumptions, the radionuclide release fractions to the atmosphere, $\mathrm{Rf}$, are presented in Table 2.4 for five types of radionuclides and the 20 modal study cask response regions. Radionuclides are grouped by physical and chemical behavior: particulates; ruthenium, cesium, and iodine isotopes; and noble or inert gases. The total release is the radionuclide inventory times the release fraction. Appendix A describes the radionuclide inventory specific to spent nuclear fuels derived for use in RISKIND. However, because it is necessary to limit the number of nuclides for each assessment when using 


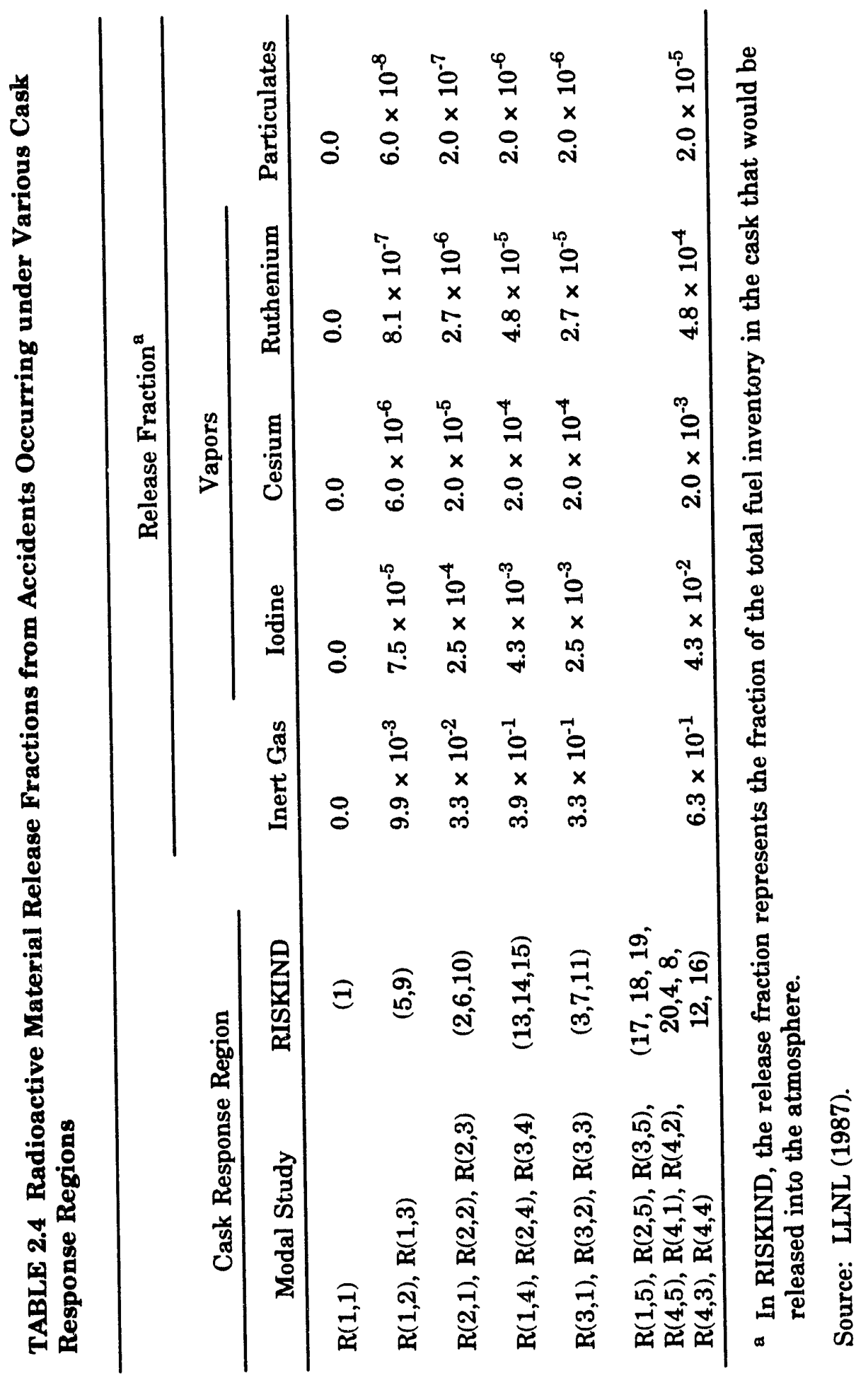


RISKIND (up to 40 nuclides), and because not all of the radionuclides are radiologically significant in the environment, a selection process was used to reduce the number of nuclides. This screening method is described in Appendix C.

Because the results of the modal study were derived from representative cask designs selected by the NRC (see Figures E.1 and E.2, Appendix E), these release fractions are used by RISKIND as default values. A separate study should be performed to derive release fractions for cask designs significantly different from those used in the NRC modal study.

The release of radioactivity in the crud is treated separately in RISKIND because crud is a mixture of reactor coolant corrosion products that have deposited on the surfaces of fuel rods and can be released during a transportation accident without severe damage to fuel cladding. Crud contains mostly neutron-activated nuclides and may also contain fissile particles and fission products. During shipment, crud may spall from the rods, become airborne in the cask cavity, and be released to the environment should a leak path develop in the cask containment system. The spalling can be caused by impact, vibration, abrasion, or a rapid thermal transient. The amount of spalled crud that may be released is dependent on the spallation properties and particle size distribution. The amount of crud plated on the spent fuel varies considerably and depends on plant operating conditions and the water chemistry of the reactor and storage pool. The amount of crud material in a cask and the fraction that could be spalled from a shipping cask during accidents are estimated on the basis of the method described in a recent Sandia National Laboratories report (Sandoval et al. 1991). The approach used in RISKIND to estimate the crud spalled during an accident is given in Appendix D. All of the spalled crud material is conservatively assumed to be released to the environment for all accident response regions except $R(1,1)$, for which no release is assumed because there is no leak path to the environment.

\subsubsection{Individual Dose Model}

\subsubsection{Atmospheric Transport Model}

The atmospheric transport model used in RISKIND is a Gaussian puff dispersion model. Radionuclides released from a shipping cask are transported by the wind and are 
diffused as a result of atmospheric turbulence. The source must be described in terms of location, physical parameters, type of radionuclide, and rate of emission. The atmospheric transport model in RISKIND calculates concentrations in air at the downwind locations for the two types of radionuclides: (1) inert gaseous radionuclides and (2) vapor or particulate radionuclides. RISKIND uses a plume-rise model developed by Briggs (1969) to estimate buoyancy rise of the release. An initial source dispersion parameter is used to model the source geometry of the release. Depending on circumstances, either the standard Pasquill-Gifford dispersion coefficients (Slade 1968; Eimutis and Konicek 1972) or the Briggs (1974) dispersion coefficients can be used. The former are suitable for ground-level releases; the latter are better for elevated releases. For vapor or particulate radionuclides, deposition of the plume content from the puff by either dry or wet deposition is also considered for any user-specified receptor location. Both air and ground concentrations of radionuclides are calculated for the estimation of exposure via various pathways.

\subsection{Theory}

The general theory on which the dispersion calculation in RISKIND is based is described in this section. Details of the dispersion model are also described, including meteorological conditions, effective emission height, initial dispersion geometry, wind powerlaw adjustment, terrain height adjustment, and depletion correction and ground contamination.

For a puff generated from a point source with an effective emission height $\mathrm{H}$ above ground level, the Gaussian dispersion equation is (Pasquill 1974)

$$
\mathrm{C}_{\mathrm{a}}(\mathrm{x}, \mathrm{y}, \mathrm{z}, \mathrm{t})=\frac{\mathrm{Q}_{\mathrm{x}}}{(2 \pi)^{3 / 2}{\sigma_{\mathrm{y}}{ }^{2} \sigma_{\mathrm{z}}}} \exp \left(-\frac{\mathrm{r}^{2}}{2 \sigma_{\mathrm{y}}{ }^{2}}\right)\left\{\exp \left[-\frac{(\mathrm{z}-\mathrm{H})^{2}}{2 \sigma_{\mathrm{z}}{ }^{2}}\right]+\exp \left[-\frac{(\mathrm{z}+\mathrm{H})^{2}}{2 \sigma_{\mathrm{z}}{ }^{2}}\right]\right\}
$$

where:

$$
\begin{aligned}
C_{a}(x, y, z, t)= & \text { air concentration at } x, y, z \text { from a release at } 0,0, H\left(C i / m^{3}\right) \\
Q_{x}= & \text { effective release source term for a receptor at } x \text { with } \\
& \text { depletion by deposition }(C i)\left(Q_{x}\right. \text { is discussed later in reference }
\end{aligned}
$$


to Equations 2.32 and 2.38 for dry and wet depositions, respectively);

$$
\begin{aligned}
\sigma_{\mathrm{y}}, \sigma_{\mathrm{z}}= & \text { dispersion coefficients }(\mathrm{m}) \text { in the horizontal and vertical } \\
& \text { directions, respectively; }
\end{aligned}
$$

$\mathbf{r}^{2}=(\mathrm{x}-\mathrm{ut})^{2}+\mathrm{y}^{2}$, for which horizontal Gaussian symmetry has been assumed (i.e., $\left.\sigma_{x}=\sigma_{y}\right)\left(\mathrm{m}^{2}\right) ; x$ is the downwind distance from the release point, and $y$ is the crosswind distance from the plume centerline;

$$
\begin{aligned}
\mathrm{u} & =\text { average wind speed }(\mathrm{m} / \mathrm{s}) ; \\
\mathrm{t} & =\text { time since release }(\mathrm{s}) ; \text { and } \\
\mathrm{H} & =\text { effective emission height }(\mathrm{m}) .
\end{aligned}
$$

The ground-level concentration $(z=0)$ for a discrete puff is

$$
\mathrm{C}_{\mathrm{a}}(\mathrm{x}, \mathrm{y}, 0, \mathrm{t})=\frac{2 \mathrm{Q}_{\mathrm{x}}}{(2 \pi)^{3 / 2} \sigma_{\mathrm{y}}{ }^{2} \sigma_{\mathrm{z}}} \exp \left\{-\left(\frac{\mathrm{r}^{2}}{2 \sigma_{\mathrm{y}}{ }^{2}}+\frac{\mathrm{H}^{2}}{2 \sigma_{\mathrm{z}}{ }^{2}}\right)\right\}
$$

As a conservative measure, the receptor is assumed to be located downwind of the plume throughout the entire course of plume passage; radionuclide decay is ignored during this time period. Thus, the time-integrated ground-level air concentration (from time of release to infinity) at the receptor is used as the concentration for the dose calculation and is calculated as

$$
\overline{\mathrm{C}}_{\mathrm{a}}(\mathrm{x}, \mathrm{y}, 0)=\int_{0}^{\infty} \mathrm{C}_{\mathrm{a}}(\mathrm{x}, \mathrm{y}, 0, \mathrm{t}) \mathrm{dt}
$$

which can be shown to be (Slade 1968)

$$
\overline{\mathrm{C}}_{\mathrm{a}}(\mathrm{x}, \mathrm{y}, 0)=\frac{\mathrm{Q}_{\mathrm{x}}}{\pi \sigma_{\mathrm{y}} \sigma_{\mathrm{z}} \mathrm{u}} \exp \left[-\left(\frac{\mathrm{y}^{2}}{2 \sigma_{\mathrm{y}}{ }^{2}}+\frac{\mathrm{H}^{2}}{2 \sigma_{\mathrm{z}}{ }^{2}}\right)\right]
$$

where $\mathrm{Q}_{\mathrm{x}}$ is the source term discussed for Equations 2.32 and 2.38. 


\subsection{Plume Reflection}

The existence of a stable air layer at high altitudes under unstable and neutral atmospheric conditions affects the atmospheric dispersion at great distances from the release point. This effect is the result of the upward dispersion of the plume, which is eventually restricted when the plume encounters an elevated stable layer (or lid) or a mixing height at some height L. In RISKIND, the plume is assumed to be reflected by this stable layer at these distances. With vertical distribution limited by reflections, Equation 2.13 becomes

$$
\overline{\mathrm{C}}_{\mathrm{a}}(\mathrm{x}, \mathrm{y}, 0)=\frac{\mathrm{Q}_{\mathrm{x}}}{\sqrt{2 \pi} u \sigma_{y} \mathrm{~L}} \exp \left(-\frac{\mathrm{y}^{2}}{2{\sigma_{y}}^{2}}\right)
$$

Equation 2.14 is used when $\sigma_{z}$ is of the same order as $\mathrm{L}$ and a uniform distribution can be assumed. The following conditions are used to determine which of these two equations, Equation 2.13 or 2.14 , is used for the dispersion calculation.

Equation 2.13 is used for distances where

$$
\frac{\sigma_{\mathrm{z}}(\mathrm{x})}{\mathrm{L}} \leq \frac{\sqrt{1-\frac{\mathrm{H}}{\mathrm{L}}}}{1.2}
$$

Equation 2.14 is used for (Powell et al. 1979)

(1) $0<\mathrm{H} / \mathrm{L}<0.5$, where

$$
\frac{\sigma_{\mathrm{z}}(\mathrm{x})}{\mathrm{L}} \geq-2.37\left(\frac{\mathrm{H}}{\mathrm{L}}\right)^{2}+0.489\left(\frac{\mathrm{H}}{\mathrm{L}}\right)+0.756 \text { and }
$$

(2) $0.5<\mathrm{H} / \mathrm{L}<1.0$, where

$$
\frac{\sigma_{z}(x)}{L} \geq-2.37\left(\frac{\mathrm{H}}{\mathrm{L}}\right)^{2}+4.25\left(\frac{\mathrm{H}}{\mathrm{L}}\right)-1.13
$$

At downwind distances between the no-mixing (Equation 2.13) and the total mixing (Equation 2.14) conditions, the concentration is determined by a linear interpolation between Equations 2.13 and 2.14. 


\subsection{Mixing Height}

The value of the mixing height (L) can be either an input value or estimated from the annual average values (Holzworth 1972). In the latter case, the mixing height is estimated from the following equation:

$$
L=\left\{\begin{array}{l}
1.5 \mathrm{~L}_{\mathrm{pm}} \text { for an extremely unstable atmosphere (stability class } A \text { ) } \\
0.5\left(\mathrm{~L}_{\mathrm{am}}+\mathrm{L}_{\mathrm{pm}}\right) \text { for a neutral atmosphere (stability class } \mathrm{D} \text { ) }
\end{array}\right.
$$

where:

$$
\begin{aligned}
& \mathrm{L}_{\mathrm{am}}=\text { mean annual morning mixing height, and } \\
& \mathrm{L}_{\mathrm{pm}}=\text { mean annual afternoon mixing height. }
\end{aligned}
$$

For other unstable situations (stability classes $B$ and $C$ ), $L$ is taken to be equal to $L_{p m}$. The mixing height does not apply to stable atmospheric conditions.

\subsection{Meteorological Conditions}

The dispersion model of RISKIND requires the following meteorological data:

1. Stability class (A through F),

2. Wind speed $(\mathrm{m} / \mathrm{s})$,

3. Mixing height (m) (for stability classes A through D),

4. Ambient temperature (K), and

5. Rain or precipitation rate $(\mathrm{mm} / \mathrm{h})$.

The dispersion model in RISKIND requires the input of weather conditions either by single stability class, wind speed, mixing height, and ambient temperature or by joint-frequency data on weather conditions over a period of time (e.g., annual data). The atmospheric stabilities are classified into six categories (A, B, C, D, E, and F) in order of increasing stability; Pasquill (1974) established criteria for stability classes. The values of $\sigma_{y}$ and $\sigma_{z}$ are strongly dependent on atmospheric stability; calculations of $\sigma_{y}$ and $\sigma_{z}$ are based on a formula derived by Briggs (1974) and Pasquill-Gifford (Eimutis and Konicek 1972). The following empirical formula was derived by Briggs (1974) from data collected from elevated releases:

$$
\sigma_{\mathbf{y}}(\mathbf{x}) \text { or } \sigma_{\mathbf{z}}(\mathbf{x})=\operatorname{ax}(1+b x)^{c}
$$


where $a, b$, and $c$ are parameters that are dependent on stability class. In addition, Briggs coefficients have been derived for two different population zones (i.e., rural and urban). Values of these parameters are given in Table 2.5. Briggs coefficients are recommended for releases occurring at elevated levels.

The empirical formula derived for Pasquill-Gifford parameters has the following forms:

$$
\sigma_{y}(x)=\left(0.000246 \sigma_{\theta}^{2}+0.00576 \sigma_{\theta}+0.066\right) x^{0.9031}
$$

and

$$
\sigma_{z}(x)=a x^{b}+c
$$

where $\sigma_{\theta}, a, b$, and $c$ are empirical parameters. Table 2.6 provides data for parameters $\sigma_{\theta}$, $a, b$, and c. It is recommended that Pasquill-Gifford coefficients be used for releases occurring at or near ground level. In RISKIND, the selection criterion for the dispersion coefficients is such that Pasquill-Gifford dispersion coefficients are used if the effective release height $H$ is less than or equal to $30 \mathrm{~m}$; otherwise, Briggs dispersion coefficients are used.

\subsection{Wind Power-Law Adjustment}

RISKIND uses a power-law function with the following form:

$$
\frac{\mathrm{U}(\mathrm{H})}{\mathrm{U}_{\mathrm{a}}}=\left(\frac{\mathrm{H}}{\mathrm{z}_{\mathrm{a}}}\right)^{\mathrm{p}}
$$

This equation is used to adjust the wind speed input $U_{a}$ from the height of measurement $z_{a}$ to the height $\mathrm{H}$ of the plume for the dispersion calculations. The default power exponent $p$ of RISKIND for each stability class is $A=0.07, B=0.07, C=0.10, D=0.15, E=0.35$, and $\mathrm{F}=0.55$ for the rural population zone; and $\mathrm{A}=0.15, \mathrm{~B}=0.15, \mathrm{C}=0.20, \mathrm{D}=0.25, \mathrm{E}=0.40$, and $F=0.60$ for the urban and suburban population zones. 
TABLE 2.5 Dispersion Coefficients for Elevated Releases

\begin{tabular}{|c|c|c|c|c|c|c|c|}
\hline \multirow[b]{3}{*}{ Weather Conditions } & \multirow{3}{*}{$\begin{array}{c}\text { Stability } \\
\text { Class }\end{array}$} & \multicolumn{6}{|c|}{$\sigma_{y}$} \\
\hline & & \multicolumn{3}{|c|}{ Rural } & \multicolumn{3}{|c|}{ Urban } \\
\hline & & a & b & c & a & b & c \\
\hline Extremely unstable & A & 0.22 & 0.0001 & -0.5 & 0.32 & 0.0004 & -0.5 \\
\hline Moderately unstable & B & 0.16 & 0.0001 & -0.5 & 0.32 & 0.0004 & -0.5 \\
\hline Slightly unstable & $\mathrm{C}$ & 0.11 & 0.0001 & -0.5 & 0.22 & 0.0004 & -0.5 \\
\hline Neutral & $\mathrm{D}$ & 0.08 & 0.0001 & -0.5 & 0.16 & 0.0004 & -0.5 \\
\hline Moderately stable & $\mathbf{E}$ & 0.06 & 0.0001 & -0.5 & 0.11 & 0.0004 & -0.5 \\
\hline \multirow[t]{3}{*}{ Very stable } & $\mathbf{F}$ & 0.04 & 0.0001 & -0.5 & 0.11 & 0.0004 & -0.5 \\
\hline & & \multicolumn{6}{|c|}{$\sigma_{\mathrm{z}}$} \\
\hline & \multirow{2}{*}{$\begin{array}{c}\text { Stability } \\
\text { Class }\end{array}$} & \multicolumn{3}{|c|}{ Rural } & \multicolumn{3}{|c|}{ Urban } \\
\hline Weather Conditions & & $\mathbf{a}$ & $\mathrm{b}$ & c & $\mathbf{a}$ & b & c \\
\hline Extremely unstable & A & 0.20 & 0.0 & 0.0 & 0.24 & 0.001 & 0.5 \\
\hline Moderately unstable & B & 0.12 & 0.0 & 0.0 & 0.24 & 0.001 & 0.5 \\
\hline Slightly unstable & $\mathrm{C}$ & 0.08 & 0.0002 & -0.5 & 0.20 & 0.0 & 0.0 \\
\hline Neutral & D & 0.06 & 0.0015 & -0.5 & 0.14 & 0.0003 & -0.5 \\
\hline Moderately stable & $\mathbf{E}$ & 0.03 & 0.0003 & -1.0 & 0.08 & 0.00015 & -0.5 \\
\hline Very stable & $\mathbf{F}$ & 0.016 & 0.0003 & -1.0 & 0.08 & 0.00015 & -0.5 \\
\hline
\end{tabular}

Source: Briggs (1974).

\subsection{Effective Emission Height}

To complete the solution for the ground-level concentration of a puff release (Equations 2.13 and 2.14), an effective radionuclide release height $\mathrm{H}$ must be calculated from the physical parameters associated with the source emission. The effective release height resulting from the plume rise was derived by Briggs (1969) and has been incorporated into RISKIND. The Briggs formulas account for release momentums and buoyancy rise, both of which are also dependent on stability class and wind speed.

Gases discharged from an accidental release will rise above the release point as a result of the momentum of the gas, such as in an accident involving fire or as a result of thermal buoyancy if the gases are substantially above ambient temperature. Because the momentum effect is not dominant for releases associated with spent nuclear fuel transportation accidents, only plume rise buoyancy is considered. The plume rise $\Delta \mathrm{h}$, when 
TABLE 2.6 Dispersion Coefficients for Ground-Level Releases

\begin{tabular}{|c|c|c|c|c|c|}
\hline \multirow{2}{*}{$\begin{array}{c}\text { Applicable Range } \\
\text { (downwind distance, } \mathrm{m} \text { ) }\end{array}$} & \multirow{2}{*}{$\begin{array}{l}\text { Stability } \\
\text { Class }\end{array}$} & \multicolumn{4}{|c|}{ Coefficients } \\
\hline & & $\sigma_{\theta}$ & a & b & c \\
\hline \multirow[t]{6}{*}{$x>1,000$} & A & 25 & 0.00024 & 2.094 & -9.6 \\
\hline & B & 20 & 0.055 & 1.098 & 2.0 \\
\hline & $\mathrm{C}$ & 15 & 0.113 & 0.911 & 0.0 \\
\hline & D & 10 & 1.26 & 0.516 & -13.0 \\
\hline & $\mathrm{E}$ & 5 & 6.73 & 0.305 & -34.0 \\
\hline & $\mathbf{F}$ & 1.5 & 18.05 & 0.18 & -48.6 \\
\hline \multirow[t]{6}{*}{$100 \leq x \leq 1,000$} & A & 25 & 0.00066 & 1.941 & 9.27 \\
\hline & B & 20 & 0.0382 & 1.149 & 3.3 \\
\hline & $\mathrm{C}$ & 15 & 0.113 & 0.911 & 0.0 \\
\hline & D & 10 & 0.222 & 0.725 & -1.7 \\
\hline & $\mathbf{E}$ & 5 & 0.211 & 0.678 & -1.3 \\
\hline & F & 1.5 & 0.086 & 0.74 & -0.35 \\
\hline \multirow[t]{6}{*}{$x<100$} & A & 25 & 0.192 & 0.936 & 0.0 \\
\hline & B & 20 & 0.156 & 0.922 & 0.0 \\
\hline & $\mathrm{C}$ & 15 & 0.116 & 0.905 & 0.0 \\
\hline & D & 10 & 0.079 & 0.881 & 0.0 \\
\hline & $\mathbf{E}$ & 5 & 0.063 & 0.871 & 0.0 \\
\hline & F & 1.5 & 0.053 & 0.814 & 0.0 \\
\hline
\end{tabular}

Source: Data from Eimutis and Konicek (1972).

added to the physical height of release point $h$, results in effective release height $H$. The elevation of the plume centerline will remain at the effective height until meteorological conditions change. Because RISKIND is designed for relatively short-distance dispersion calculations, such changes in meteorological conditions are not considered; consequently, the effective plume height remains the same throughout the course of plume passage.

The following method by Briggs (1969) is used to estimate buoyant plume rise. For stability classes $A, B, C$, and $D$, the plume rise is given by

$$
\begin{aligned}
& \Delta h=\frac{1.6 F^{1 / 3} x^{2 / 3}}{u}, \text { for } x \leq 10 h \\
& \Delta h=\frac{1.6 F^{1 / 3}(10 h)^{2 / 3}}{u}, \text { for } x>10 h
\end{aligned}
$$


where:

$$
\begin{aligned}
\Delta h= & \text { plume rise }(\mathrm{m}), \text { which is also equal to } H-h ; \\
F= & 3.7 \times 10^{-5} \mathbf{Q}_{h}\left(Q_{h}\right. \text { is the heat flux due to the afflux of released gases, } \\
& \text { in cal } / \mathrm{s}) ; \\
\mathbf{h}= & \text { physical release height }(\mathrm{m}) ; \\
\mathbf{x}= & \text { distance downwind }(\mathrm{m}) ; \text { and } \\
\mathbf{u}= & \text { wind speed }(\mathrm{m} / \mathrm{s}) .
\end{aligned}
$$

For stability classes E and F, Equation 2.19 is also used for distances up to $x=2.4 u^{-1 / 2}$, beyond which the plume is assumed to level off. For higher values of $x$,

$$
\Delta \mathrm{h}=2.9(\mathrm{~F} / \mathrm{us})^{1 / 3}
$$

where $\mathbf{s}$ is the stability parameter defined as

$$
\mathrm{s}=\mathrm{g} / \mathrm{T}_{\mathrm{a}}\left(\frac{\partial \mathrm{T}_{\mathrm{a}}}{\partial \mathrm{z}}+\ell\right)
$$

where:

$$
\begin{aligned}
\mathrm{g}= & \text { gravitational acceleration }\left(\mathrm{m} / \mathrm{s}^{2}\right), \\
\mathrm{T}_{\mathrm{a}}= & \text { ambient air temperature }(\mathrm{K}), \\
\mathrm{z}= & \text { vertical distance above the release point }(\mathrm{m}), \\
\ell= & \text { normal adiabatic lapse rate of atmosphere }(0.0098 \mathrm{~K} / \mathrm{m}), \text { and } \\
\frac{\partial \mathrm{T}_{\mathrm{a}}}{\partial \mathrm{z}}+\ell= & \text { potential temperature lapse rate }(0.002 \text { for stability class } \mathrm{E} \text { and } \\
& 0.035 \text { for stability class } \mathrm{F}) .
\end{aligned}
$$

Equations 2.23 through 2.26, which have been recommended by Briggs, contain wind speed in the denominator; this would produce unrealistically high values of infinite plume rise for very low wind speeds. Because the Briggs equations are applicable only to windy conditions, a minimum wind speed of $0.1(\mathrm{~m} / \mathrm{s})$ is imposed in the above plume-rise calculations. 
For stable situations when the wind is so light that the plume rises vertically, the final plume rise is given by Briggs as

$$
\Delta \mathrm{h}=5.0 \mathrm{~F}^{1 / 4} \mathrm{~s}^{-3 / 8}
$$

In RISKIND, the smaller value of $\Delta \mathrm{h}$ from Equations 2.25 and 2.27 is used for the final plume rise for a stable atmosphere (stability classes $\mathrm{E}$ and F).

\subsection{Initial Dispersion Geometry}

The initial dispersion of the plume at the source is modeled according to the method of virtual point source by Petersen and Laudas (1986). For releases at high elevations, the initial dispersion usually has little influence on downwind concentrations. However, if the source is large enough or close enough to the ground, then the initial size is important in determining ground-level concentrations near the source. For a cask near the ground, the initial horizontal dispersion is calculated by dividing the cask horizontal dimension by 4.3; the initial vertical dispersion parameter is derived by dividing the physical height of the cask by 2.15 (Petersen and Laudas 1986). These initial dispersion parameters are then used to estimate the virtual source location. This method of accounting for the cask size of a nearground-level release gives reasonable concentration estimates at downwind distances greater than approximately five times the initial horizontal dimension of the cask.

\subsection{Buoyancy-Induced Dispersion}

Buoyancy-induced dispersion is considered in RISKIND because emitted plumes undergo a certain amount of growth during the plume-rise phase as a result of turbulent motions associated with plume release conditions and turbulent entrainment of ambient air. Pasquill (1974) suggests that this induced dispersion, $\sigma_{\mathrm{zb}}$, can be approximated by the following equation:

$$
\sigma_{\mathrm{zb}}=\frac{\Delta \mathrm{h}}{3.5}
$$

The effective dispersion can then be determined by adding variances such as

$$
\sigma_{\mathrm{ze}}=\left(\sigma_{\mathrm{zb}}^{2}+\sigma_{\mathrm{z}}^{2}\right)^{1 / 2}
$$


where $\sigma_{\mathrm{ze}}$ is the effective dispersion and $\sigma_{\mathrm{z}}$ is the dispersion due to ambient turbulence

levels. At the distance of final rise and beyond, $\sigma_{\mathrm{zb}}$ is a constant when the plume rise $(\Delta \mathrm{h})$ of the final rise is used.

Because the plume can be assumed to be symmetrical about its centerline in the initial growth phases of release, the calculation assumes that buoyancy-induceci dispersion in the horizontal direction is equal to that in the vertical direction, $\sigma_{y_{b}}=\Delta \mathrm{h} / 3.5$. This expression is combined with that for dispersion due to ambient turbulence in the same manner described above for the vertical direction. These effective dispersion parameters are used to replace $\sigma_{z}$ values in equations necessary to calculate concentrations in the air.

In general, buoyancy-induced dispersion has little effect on maximum concentrations unless the release height is small compared with the plume rise. Also, buoyancy-induced dispersion is most effective in simulating concentrations near plume centerlines close to the source, where treating the emission as a point source confines the plume to a volume much smaller than the actual plume.

\subsection{Terrain Height Adjustment}

Ridges and hills downwind from a transportation accident require that the release height derived for flat terrain be adjusted to account for the terrain deviations. Stabilitydependent plume-path coefficients are used in RISKIND to calculate the effects of terrain elevation on the height of the nlume centerline. The terrain-corrected effective release height $\left(\mathrm{H}_{\mathrm{t}}\right)$ above the terrain is calculated by the following equation (Ross et al. 1985):

$$
H_{t}=H-\left(1-P_{c}\right)\left[\min \left(H, E_{r}-E_{p}\right)\right]
$$

where:

$$
\begin{aligned}
H & =h+\Delta h, \text { effective release height }(\mathrm{m}) ; \\
\mathrm{h} & =\text { physical release height }(\mathrm{m}) ; \\
\Delta \mathrm{h} & =\text { plume rise }(\mathrm{m}) ; \\
\mathrm{P}_{\mathrm{c}} & =\text { plume-path coefficient (discussed in the following); } \\
\mathrm{E}_{\mathrm{r}} & =\text { receptor elevation }(\mathrm{m}) ; \text { and } \\
\mathrm{E}_{\mathrm{p}} & =\text { release elevation }(\mathrm{m}) .
\end{aligned}
$$


For neutral and unstable atmospheric conditions (stability classes A, B, C, and D), the plume is lifted half the difference between the elevation of the receptor and the elevation of the base of release point. In addition, the plume must always be at least half the height above ground that it would be with no topography. Under such conditions, the plume-path coefficient $P_{c}$ is set at 0.5 . For stable conditions, it must be at least one-third the height. The value of $P_{c}$ is then set at 0.3. A plume-path coefficient $\left(P_{c}\right)$ of 1 represents a flat, nonterrain-lifted plume.

\subsection{Depletion Correction and Ground Contamination}

Methods for calculating ground contamination from radionuclide deposition are described in this section. Two mechanisms of deposition (i.e., dry and wet deposition) account for radionuclide depletion from the plume.

Dry Deposition. With the exception of inert gases, all fission products released from a shipping cask will primarily be in particulate form. Unless the shipping casks are severely damaged, these particulates are generally released in small sizes (i.e., less than a few microns). The vertical movement of these small particles is largely dependent on the vertical turbulence and mean motion of the air; settling of the particles by gravity is minimal. Deposition of such small particles on the ground surface is the result of turbulent diffusion and Brownian motion. Chemical absorption, impactica, and other physical and chemical processes cause the material to be retained at the surface. Such a deposition mechanism depletes the amount of radioactivity in the plume and thus affects the potential radiological hazards as the plume travels farther downwind. Radiological hazards to individuals occur by way of either direct exposure from the ground or indirect exposure via the ingestion of contaminated foodstuff.

Calculation of the dry deposition rate involves the concept of deposition velocity, that is, the ratio of the deposition rate to the air concentration expressed in units of velocity. The time-integrated ground surface concentration $C_{g}(x, y)$ is given by

$$
C_{g}(x, y)=\bar{C}_{a}(x, y) V_{d}
$$


where $V_{d}$ is the deposition velocity. The deposition velocity $\left(V_{d}\right)$ is determined from either field or laboratory measurements of air and ground concentrations.

Many measurements of dry deposition velocity have been reported by McMahon and Dennison (1979) and Sehmel (1980). Values for particulates range over several orders of magnitude and depend on meteorological conditions, surface conditions, and nuclide types. Table 2.7 presents the deposition velocity range for various particulate radionuclides. $A$ default value of $0.001 \mathrm{~m} / \mathrm{s}$ is used for the $V_{d}$ for particulates in RISKIND. However, the user may assign a site-specific value rather than the default value.

When depletion by deposition is considered, the initial source term $Q_{0}$ at the release point can be replaced by a depleted source term $\mathbf{Q}_{\mathbf{x}}$ along the downwind sector. In this approach, it is assumed that the depletion reduces only the effective source strength and that the vertical Gaussian profile remains unchanged. In this derivation, the total activity has been conserved.

The reduced source strength $Q_{x}$ due to deposition is calculated from the following equation:

$$
Q_{x}=Q_{0} \exp \left[-\frac{v_{d}}{\left(\frac{\pi}{2}\right)^{1 / 2} u} \int_{0}^{x} \exp F(x) d x\right]
$$

where $Q_{0}$ is the initial release inventory of radionuclides. At downwind distances not affected by the presence of a mixing layer,

$$
F(x)=-\frac{1}{2}\left(\frac{H^{2}}{\sigma_{z}^{2}}\right) / \sigma z
$$

At downwind distances where total mixing by the presence of a mixing layer can be assumed,

$$
F(x)=\frac{1}{L}
$$

At downwind distances between the nonmixing (2.33) and total mixing (2.34) conditions, $F(x)$ is determined by a linear combination of Equations 2.33 and 2.34. The integral expressions in Equation 2.32 are evaluated numerically in RISKIND by using a Simpson's rule computer subroutine. 
TABLE 2.7 Deposition Velocity Data Summary for Particulate Radionuclides

\begin{tabular}{lll}
\hline \multicolumn{1}{c}{ Depositing Material } & \multicolumn{1}{c}{$\begin{array}{c}\text { Deposition Velocity } \\
(\mathrm{cm} / \mathrm{s})\end{array}$} & \multicolumn{1}{c}{$\begin{array}{c}\text { Deposition } \\
\text { Surface }\end{array}$} \\
\hline Barium & $0.001-0.006$ & Grass \\
Strontium & $0.002-0.01$ & Grass \\
Radium & $0.05-0.5$ & Tank \\
Plutonium & $3.2-7.3$ & Tray \\
Cesium-137 & $0.09 \pm 0.06$ & Water \\
& $0.04 \pm 0.05$ & $\begin{array}{l}\text { Soil } \\
\text { Grass }\end{array}$ \\
Ruthenium-103 & $0.2-0.05$ & Water \\
& $2.3 \pm 1.0$ & Soil \\
& $0.1 \pm 0.2-0.6 \pm 0.4$ & Grass \\
Zirconium-95, Niobium-95 & $0.02-0.8$ & Water \\
& $5.7 \pm 3.4$ & Soil \\
Beryllium-7 & $2.9 \pm 2.7$ & Ocean with rain \\
Tellurium-127, Tellurium-129 & $0.7 \pm 1.3$ & Sticky paper \\
\hline
\end{tabular}

Source: Sehmel (1980).

Wet Deposition. Radionuclides can also be removed from a plume by rain or snowfall. In wet deposition, the depletion mechanism of radionuclides is such that the plume is "washed out" by rain or snow. Thus, the wet deposition rate is dependent on the total amount of radioactivity contained in the plume, in contrast to dry deposition for which the depletion is closely related to the air concentration at ground level. The fraction of material removed per unit time by wet deposition is known as the "washout coefficient," $V_{w}$, and is defined as follows:

$$
\mathrm{V}_{\mathrm{w}}=-\frac{1}{\mathrm{C}_{\mathrm{a}}} \frac{\mathrm{dC}_{\mathrm{a}}}{\mathrm{dt}}
$$

where $\mathrm{C}_{\mathrm{a}}$ equals the local particulate air concentration. Calculated and measured values of the washout coefficient range from about $1.0 \times 10^{-5}$ to $1.0 \times 10^{-2}$ per second (Ritchie et al. 
1978; McMahon and Dennison 1979). The value of the washout coefficient increases with an increasing rainfall rate, $R(\mathrm{~mm} / \mathrm{h})$. In RISKIND, it is assumed that the washout coefficient is linearly dependent on the rainfall rate:

$$
\mathrm{V}_{\mathrm{w}}=\mathrm{W}_{\mathrm{c}} \mathrm{R}
$$

where $W_{c}$ is assumed to be $1.0 \times 10^{-4}(1 / \mathrm{s})(1 /[\mathrm{mm} / \mathrm{h}])$ for stable atmospheric conditions (i.e., warm frontal storm; stability classes $\mathrm{E}$ and $\mathrm{F}$ ), and $1.0 \times 10^{-3}$ for unstable atmospheric conditions (i.e., convective storms; stability classes $\mathrm{A}$ to $\mathrm{D}$ ).

The ground contamination in the precipitation region is given by

$$
C_{g}(x, y)=\frac{Q_{x} V_{w}}{(2 \pi)^{1 / 2} \sigma_{y} u} \exp \left(-\frac{y^{2}}{2 \sigma_{y}^{2}}\right)
$$

where $C_{g}$ can be expressed in $\mathrm{Ci} / \mathrm{m}^{2}$, and $Q_{x}$ is the depleted source strength at downwind distance $\mathbf{x}$.

For a steady rainfall rate and wind speed, $Q_{x}$ is given by

$$
\mathbf{Q}_{\mathbf{x}}=\mathbf{Q}_{0} \exp \left(-\mathrm{V}_{\mathrm{w}} \mathrm{x} / \mathrm{u}\right)
$$

For low rainfall rates (i.e., a few millimeters per hour), Equations 2.37 and 2.38 are adequate. For high rainfall rates, the redistribution of the deposited radioactivity from surface runoff should be taken into account while evaluating the ground contamination from washed activity. Such conditions are not included in RISKIND.

\subsubsection{Environmental Pathway and Dosimetry Models}

Two basic elements are necessary to assess human health hazards from released radioactivity. First, the concentrations of radioactive material in the environmental media must be determined. Second, the pathways of exposure that should be considered must be selected. The environmental pathways following an accidental release and the potential exposure modes are shown in Figure 2.4. For an accidental release over a short duration, such as that considered in RISKIND, the concentrations of contaminants along the dispersive paths generally build up to a maximum value shortly after the release and decrease steadily thereafter. 


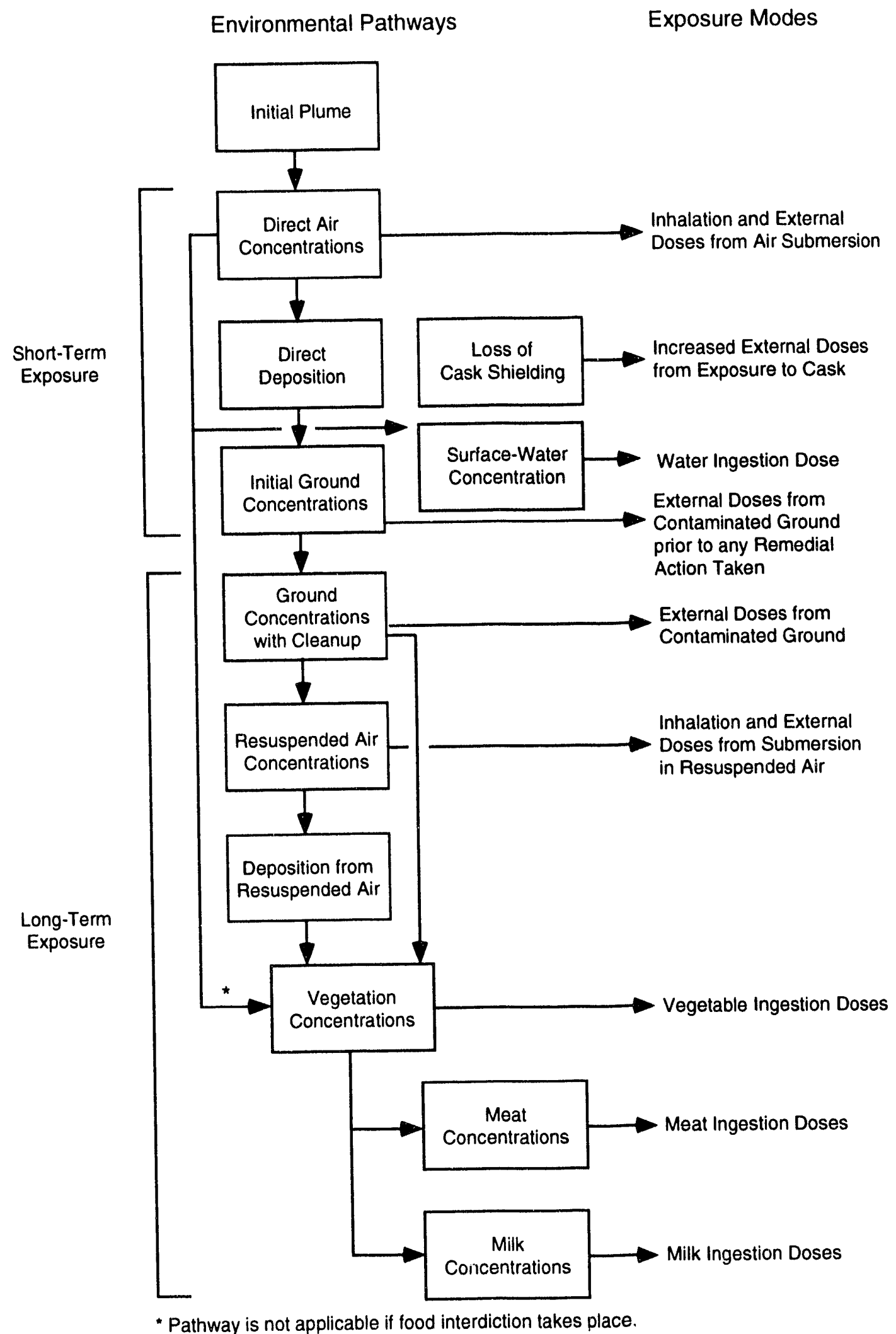

FIGURE 2.4 Environmental Pathways and Exposure Modes for a Spent Nuclear Fuel Cask Accident 
Adequate prediction of health hazards to an individual depends on an accurate description of the time-dependent behavior of contaminants in the environment. A small change in a time constant can significantly affect the magnitude of exposure. Following an airborne release of relatively short duration, radioactive material becomes airborne as the "radioactive cloud" is dispersed and diluted by turbulent diffusion. When the cloud passes over an area, the people occupying that area may be exposed to radiation emanating from the cloud and may also inhale radioactive material suspended in air.

In RISKIND, exposure resulting from the initial passing plume is categorized as short-term because it is of relatively short duration and the radioactive material is relatively concentrated. In addition to the exposure received from the passing plume, external exposure due to the loss of cask shielding may also contribute to short-term exposure. Modeling of short-term radiation exposure is described in Section 2.2.2.3. Exposure via the sequence of radionuclide depletion from the cloud is categorized as long-term because the deposited contaminant may persist in the environment over a prolonged period of time following the initial release. In general, the radiological hazards to individuals tend to be lower from longterm exposures than short-term exposures because the radionuclide concentrations in the environmental media are diluted further in the long-term cases. However, the cumulative dose to the exposed individual over the long term could be potentially significant for cases in which no remediation is taken following an accident.

Several environmental pathways are identified for long-term exposures: exposure from the contaminated ground, inhalation of radioactive materials resuspended in the air, and ingestion of contaminated foodstuffs. In addition, initial deposition onto surface water bodies may also result in dose exposure via the drinking water pathway. The models used to calculate environmental media concentrations from long-term modes of exposure are described in Section 2.2.2.4. Once the radionuclide concentrations in the environmental media are determined, the doses to individuals can be calculated. The dosimetry models used to calculate the environmental media concentrations are described in Section 2.2.2.4.

Radiation doses are calculated only for individuals at each receptor location defined by the user. These receptor locations are normally defined to represent locations where potentially higher exposures are likely as the result of a release. The estimate of early health effects is dependent on the exposure information from short-term exposures; the estimate for 
latent health effects is dependent on the total dose from both short-term and long-term exposures. A discussion of health effects models is presented in Section 3.

\subsubsection{Short-Term Exposure}

The model used to calculate short-term radiation doses is described in this section. Such doses include external radiation from radionuclides in the passing cloud and radionuclides deposited on the ground, external exposure from loss of cask shielding, and internal radiation from inhaled radioactive material.

\subsection{External Exposure from the Radioactive Cloud}

External radiation doses received from a radioactive cloud are calculated as the product of the time-integrated air concentration $\overline{\mathrm{C}}_{\mathrm{a}}$ and the cloud gamma dose conversion factor:

$$
D_{E x a}=K_{1} \sum_{i} \bar{C}_{a}(i) \cdot D F_{E x a}(i)
$$

where:

$$
\begin{aligned}
& D_{E x a}=\text { dose received from exposure to the radioactive cloud (mrem), } \\
& \mathrm{K}_{1}=\text { unit conversion constant }\left(2.78 \times 10^{-4} \mathrm{~h} / \mathrm{s}\right) \text {, } \\
& \overline{\mathrm{C}}_{\mathrm{a}}(\mathrm{i})=\text { time-integrated air concentration (Equation 2.13) for } \\
& \text { radionuclide } \mathrm{i}\left(\mathrm{Ci}-\mathrm{s} / \mathrm{m}^{3}\right) \text {, and } \\
& \mathrm{DF}_{\mathrm{Exa}}(\mathrm{i})=\text { cloud dose factor for radionuclide } \mathrm{i}\left(\mathrm{mrem} / \mathrm{h} \text { per } \mathrm{Ci} / \mathrm{m}^{3}\right) \text {. }
\end{aligned}
$$

\subsection{External Exposure from Ground-Deposited Radionuclides}

A passing cloud of radioactive material can deposit its radioactive contents on the ground by either dry or wet deposition, as described in Section 2.2.2.1. The deposited 
radioactive material can become a source of external radiation. The external exposure dose from radioactive material deposited on the ground is calculated by

$$
\mathrm{D}_{\text {Exg }}=\sum_{i} \mathrm{DF}_{\mathrm{Exg}}(\mathrm{i}) \mathrm{C}_{\mathrm{g}}(\mathrm{i}) \mathrm{T}_{\mathrm{Exg}}
$$

where:

$$
\begin{aligned}
\mathrm{D}_{\mathrm{Exg}}= & \text { short-term external dose from ground-deposited radioactivity } \\
& (\mathrm{mrem}), \\
\mathrm{DF}_{\mathrm{Exg}}(\mathrm{i})= & \text { dose conversion factor for external radiation from ground } \\
& \text { contamination }\left(\mathrm{mrem} / \mathrm{h} \text { per } \mathrm{Ci} / \mathrm{m}^{2}\right), \\
\mathrm{C}_{\mathrm{g}}(\mathrm{i})= & \text { ground surface concentration (Equation } 2.31 \text { or } 2.37) \text { for } \\
& \text { radionuclide } \mathrm{i}\left(\mathrm{Ci} / \mathrm{m}^{3}\right) \text { immediately following the release, and } \\
\mathrm{T}_{\mathrm{Exg}}= & \text { duration of the exposure }(\mathrm{h}) .
\end{aligned}
$$

The dose conversion factors used for this mode of exposure are also taken from the DOE report on external dose-rate conversion factors (DOE 1988). The parameter $\mathrm{T}_{\mathrm{Exg}}$ is the time from the accident to the time of evacuation (default value $=2 \mathrm{~h}$ ). These factors were derived for a point $1 \mathrm{~m}$ above an infinite plane surface. Shielding from structures can be accounted for by use of a shielding factor as appropriately determined by the user.

\subsection{External Exposure from Loss of Cask Shielding}

Loss of cask shielding in a transportation accident may result in increased external exposure to the affected individuals. Such an event may involve, for example, the loss of neutron shielding in an accident involving fire, or the loss of gamma shielding due to the lead slump resulting from severe impact.

Doses from such accidental exposures are modeled after Equation 2.3 and can be expressed as

$$
D_{\text {ext }}(r)=\dot{D}_{0}\left[M_{g} f_{g} R_{g}(r)+M_{n} f_{n} R_{n}(r)\right] T_{e x t}
$$

where $\dot{D}_{0}, f_{g}, f_{n}, R_{g}(r)$, and $R_{n}(r)$ have been defined in Equation 2.1; $M_{g}$ and $M_{n}$ are the dose multiplication factors for gamma and neutron radiation due to loss of shielding; and $T_{\text {ext }}$ is 
the duration of the exposure. Both $M_{g}$ and $M_{n}$ can be calculated from existing shielding codes and input by the user. Similar to the ground exposure situation, $T_{\text {ext }}$ is assumed to be the time from the accident to the time of evacuation (default value $=2 \mathrm{~h}$ ) or to the time the damaged cask is removed. The dose multiplication factors are the increased dose rates measured in multiples of dose rates for incident-free conditions.

If external shielding, such as that from a building, can be credited for individual exposures, the above dose can be rewritten as

$$
D_{\text {ext }}(r)=\dot{D}_{0}\left[M_{g} S F_{g} f_{g} R_{g}(r)+M_{n} S F_{n} f_{n} R_{n}(r)\right] T_{e x t}
$$

where $\mathrm{SF}_{\mathrm{g}}$ and $\mathrm{SF}_{\mathrm{n}}$ are the shielding factors for gamma and neutron radiation and are set at a default value of 1.0 for outdoor exposure.

For exposure to a population subgroup under this exposure scenario, the population dose is estimated by

$$
D_{p}=N_{p} \dot{D}_{\text {ext }}\left(r_{0}\right) T_{\text {ext }}
$$

where:

$$
\begin{aligned}
& D_{p}=\text { population dose for population subgroup } p \text { (person-mrem), } \\
& N_{p}=\text { number of exposed people in population subgroup } p \text {, and } \\
& r_{0}=\text { exposure distance }(m) .
\end{aligned}
$$

For exposure to members of the public, the population density can be assumed to be uniform within two concentric circles (representing minimum and maximum distances) around the cask. In this situation, the population dose is estimated by

$$
D_{\text {ext }}^{s}=2 \pi P D T_{\text {ext }} \int_{r_{1}}^{r_{2}} D_{\text {ext }}(r) r d r
$$

where:

$$
\begin{aligned}
\mathrm{D}_{\text {ext }}^{\mathrm{s}} & =\text { population dose (person-mrem) } \\
\mathrm{PD} & \left.=\text { population density at accident location (persons } / \mathrm{m}^{2}\right), \text { and } \\
\mathrm{r}_{1}, \mathrm{r}_{2} & =\text { minimum and maximum exposure distances }(\mathrm{m}) .
\end{aligned}
$$




\subsection{Exposure from Inhaled Radionuclides}

Individuals can be exposed to radiation by inhaling radioactive particles and/or gases. Although some of this inhaled material is immediately exhaled, a fraction is retained in the body of the individual. The fraction retained depends on the particle size distribution, the radionuclide's solubility in body fluid, and the individual's breathing rate. The inhalation dose is calculated as follows:

$$
D_{\text {Inh }}=\sum_{i} \bar{C}_{a}(\mathrm{i}) \cdot D F_{I n h}(i) B r
$$

where:

$$
\begin{aligned}
\mathrm{D}_{\text {Inh }} & =\text { short-term inhalation dose (mrem), } \\
\overline{\mathrm{C}}_{\mathrm{a}}(\mathrm{i}) & =\text { time-integrated air concentration for radionuclide } \mathrm{i}\left(\mathrm{Ci}-\mathrm{s} / \mathrm{m}^{3}\right), \\
\mathrm{DF}_{\mathrm{Inh}}(\mathrm{i}) & =\text { inhalation dose conversion factor }(\mathrm{mrem} / \mathrm{Ci}), \text { and } \\
\mathrm{Br} & \left.=\text { breathing rate (default: } 2.3 \times 10^{-4} \mathrm{~m}^{3} / \mathrm{s}\right) .
\end{aligned}
$$

In RISKIND, all particle sizes are assumed to be respirable. The dose factors are taken from Limiting Values of Radionuclide Intake and Air Concentration and Dose Conversion Factors for Inhalation, Submersion, and Ingestion (EPA 1988). The dose factors are for an activity median aerodynamic diameter (AMAD) ${ }^{*}$ of $1 \mu \mathrm{m}$ and the solubility class that would yield the highest effective dose equivalent.

\subsubsection{Long-Term Exposure}

The models, equations, and data employed in the determination of long-term individual doses are described in this section. In determining these doses, the radionuclide concentrations in the environmental media following a release are first calculated. These concentrations are then used in the calculation of long-term doses, that is, those doses resulting from the deposition and reconcentration of radionuclides in environmental media subsequent to the passing of the initial plume. These media include ground surface;

* The activity median aerodynamic diameter (AMAD) is the diameter of a unit density sphere that has the same terminal settling velocity in air as an aerosol particle whose activity is the median for the entire aerosol (ICRP 1966). 
resuspended air; and vegetation, meat, and milk. For convenience, symbols representing

time-integrated media concentrations are capped with a bar (e.g., $\overline{\mathrm{C}}_{\mathrm{a}}$ ); symbols representing instantaneous concentrations are not capped.

\subsection{Environmental Media Concentration Models}

Long-term environmental media concentrations are calculated as functions of the ground concentrations that result directly from deposition of radionuclides from the passing cloud and the amount of time that an individual is exposed to these concentrations. The ground concentrations related to these pathways can be calculated from the time-integrated: air concentrations described in Section 2.2.2.1. Figure 2.4 shows the environmental pathways following an accidental release and the expcsure modes. Concentrations in the environmental media can be further enhanced by ground disturbance, which causes resuspension of the deposited radionuclides. Depositions of resuspended concentrations in air and on the ground are also considered in calculating accumulated concentrations in various types of vegetation, including hay and forage. Concentrations in hay and forage are used to calculate radioactivity concentrations in meat and milk inger,ted by humans. In the following discussion, the initial and time-dependent concentrations in the environmental media are derived first, then the time-integrated concentrations over a prolonged period after deposition are derived.

\subsection{Ground Surface Concentrations}

Ground surface concentrations are calculated from time-integrated air concentrations $\left(\overline{\mathrm{C}}_{\mathrm{a}}\right)$ arising directly from accidental releases. The initial ground surface concentration $\left(\mathrm{Ci} / \mathrm{m}^{2}\right)$ of radionuclide $\mathrm{i}, \mathrm{C}_{\mathrm{g}}(\mathrm{i}, 0)$, following an accidental release is calculated by Equations 2.31 and 2.35, respectively, under dry and wet deposition conditions.

The concentration of radionuclide $i$ on a ground surface at time $t$ ( $y r$ ) following a release is related to the initial concentration as

$$
C_{g}(i, t)=C_{g}(i, 0)\left\{\exp -\left[\lambda(i)+\lambda_{g}\right] t\right\}
$$


where:

$$
\begin{aligned}
C_{g}(i, t)= & \text { ground surface concentration of radionuclide } i \text { at time } t \text { following } \\
& \text { a release }\left(\mathrm{Ci} / \mathrm{m}^{2}\right), \\
\lambda(\mathrm{i})= & \text { radioactive decay constant for radionuclide } \mathrm{i}(1 / \mathrm{yr}), \text { and } \\
\lambda_{\mathrm{g}}= & \text { rate constant for environmental loss }(1 / \mathrm{yr})(\text { default: } 0.014) .
\end{aligned}
$$

The environmental loss constant $\lambda_{\mathbf{g}}$ is derived from an assumed half-life in the soil (default: 50 yri with respect to environmental availability. This parameter is used to account for loss through chemical binding during downward migration in soil and other environmental loss mechanisms such as wind or water erosion. It is assumed that this parameter applies to all radionuclides suiject to ground deposition.

\subsection{Resuspended Air Concentrations}

Resuspended air concentrations are calculated with a time-dependent resuspension factor, which, for deposits of age $t \mathbf{y r}$, is

$$
R_{p}(t)=\left\{\begin{array}{l}
F I \exp \left(-\lambda_{r} t\right), \text { for } t \leq T_{a} y r \\
F E, \text { for } t>T_{a} y r
\end{array}\right.
$$

where:

$$
\begin{aligned}
R_{p}(t)= & \text { ratio of resuspended air concentration to ground concentration for } \\
& \text { a ground concentration at time } t \mathrm{yr}(1 / \mathrm{m}), \\
\mathrm{FI}= & \text { initial value of the resuspension factor (for fresh deposits) (default: } \\
& \left.1.0 \times 10^{-5} \mathrm{1} / \mathrm{m}\right), \\
\lambda_{\mathrm{r}}= & \text { assumed decay constant of the resuspension factor (default: } \\
& 5.061 / \mathrm{yr}), \\
\mathrm{FE}= & \text { terminal value of the resuspension factor (default: } \left.1.0 \times 10^{-9}\right) \text {, and } \\
\mathrm{T}_{\mathrm{a}}= & \text { time required for resuspension factor to decrease from its initial to } \\
& \text { terminal value (yr) (default: } 1.82 \mathrm{yr}) .
\end{aligned}
$$


The basic formulation of the $a b$ :ve expression for the resuspension factor, the initial and terminal values, and the assigned default decay constant were first derived from experimental results of plutonium resuspension measurements (Anspaugh 1973; Anspaugh et al. 1974; NRC 1974; Volchok 1986). The resuspended air concentration may be derived by the following equation:

$$
C_{r}(i, t)=C_{g}(i, t) R_{p}(t)
$$

where $C_{r}(i, t)$ is the rr iuspended air concentration of radionuclide $i$ at time $t$ following an accidental release. This approach has been shown to predict results consistent with the recent data collected from Europe after the Chernobyl accident (International Atomic Energy Agency [IAEA] 1992).

\subsection{Concentrations in Vegetation}

Concentrations in vegetation may be the result of direct deposition from the initial passing plume (short-term) or of root uptake from soil and deposition through resuspension (long-term). Radionuclide concentrations in vegetation are derived from ground concentrations and resuspended air-concentration deposition rates. Ground concentrations are used to determine concentrations in vegetation that are the result of root uptake of soil radioactivity; depositions are used to determine concentrations in vegetation that are the result of foliar retention of deposited radioactivity. Two categories of vegetation are treated in RISKIND: vegetables consumed by humans and pasture grass (or hay) that is fed to animals that provide food for human consumption. The concentration on vegetation by direct deposition can be expressed by (NRC 1977a)

$$
C_{v}(i)=\frac{\bar{C}_{a}(i) V_{d} F_{r} E_{v}\left[\exp \left(-\lambda_{w} T_{v}\right)\right]}{Y_{v}}
$$

where:

$$
\begin{aligned}
\mathrm{C}_{\mathrm{v}}(\mathrm{i}) & =\text { vegetation concentration of radionuclide } \mathrm{i}(\mathrm{Ci} / \mathrm{kg}), \\
\overline{\mathrm{C}}_{\mathrm{a}}(\mathrm{i}) & =\text { integrated air concentration of radionuclide } \mathrm{i}\left(\mathrm{Ci}-\mathrm{s} / \mathrm{m}^{3}\right), \\
\mathrm{V}_{\mathrm{d}} & =\text { deposition velocity }(\mathrm{m} / \mathrm{s}), \\
\mathrm{F}_{\mathrm{r}} & =\text { fraction of deposition retained on the plant, }
\end{aligned}
$$




$$
\begin{aligned}
E_{v}= & \text { fraction of foliar deposition reaching edible portions of veg- } \\
& \text { etation } v \text { (for pasture grass } E_{v} \text { is assumed to be } 1 \text { ), } \\
\lambda_{w}= & \text { decay constant for weathering losses }(1 / \mathrm{s}), \\
T_{v}= & \text { duration from accidental release to first harvest (s), and } \\
Y_{v}= & \text { yield density of vegetation } v\left(\mathrm{~kg} / \mathrm{m}^{2}\right)
\end{aligned}
$$

Equation 2.49 is used to calculate radionuclide concentrations in vegetation of the first harvest following a release. If the initially contaminated vegetation is in terdicted, the concentration would be zero.

The vegetation concentration over the long term resulting from ground contamination can be expressed by

$$
C_{v}(i, t)=C_{g}(i, t) S_{v}(i)+C_{r}(i, t) A_{v}(i)
$$

where:

$$
\begin{aligned}
C_{v}(i, t)= & \text { concentration of radionuclide } i \text { in vegetation } v \text { at time } t \text { following } \\
& \text { an accidental release }(p C i / k g) ; \\
S_{v}(i)= & B_{v}(i) / \rho ; \\
B_{v}(i)= & \text { soil-to-plant transfer factor for radionuclide } i \text {, vegetation } v \text { (see } \\
& \text { Table } 2.8) ; \\
p= & \text { effective surface density of soil (default } 240 \mathrm{~kg} / \mathrm{m}^{2} \text { assumes a } \\
& \text { 15-cm plow layer); and } \\
A_{v}(i)= & V_{d} F_{r} E_{v}\left\{\left[1-\exp \left(-\lambda_{w} t_{v}\right)\right] /\left(Y_{v} \lambda_{w}\right)\right\} .
\end{aligned}
$$

The first term of Equation 2.50 represents the plant root uptake mechanism; the second term represents the resuspension and the redeposition. In Equations 2.49 and 2.50, the value of $V_{d}$ is assumed to be $0.01 \mathrm{~m} / \mathrm{s}$, and the value of $F_{r}$ is assumed to be 0.2 for all vegetation. The value of $t_{v}$ is assumed to be 60 days, except for pasture grass, for which a value of 30 days is used. The yield density $Y_{v}$ is assumed to be $2 \mathrm{~kg} / \mathrm{m}^{2}$, except for pasture grass; for pasture grass a value of $0.75 \mathrm{~kg} / \mathrm{m}^{2}$ is used. The areal soil density $\rho$ is assumed to be $2.4 \times 10^{2} \mathrm{~kg} / \mathrm{m}^{2}$. The soil-to-plant transfer factors, $B_{v}(i)$, are listed in Table 2.8 for various radionuclides. 
TABLE 2.8 Transfer Coefficients Applicable to Food Chain Pathways for Various Radionuclides

\begin{tabular}{|c|c|c|c|c|}
\hline \multirow[b]{2}{*}{$\begin{array}{c}\text { Index } \\
\text { (i) }\end{array}$} & \multirow[b]{2}{*}{ Element } & \multicolumn{3}{|c|}{ Transfer Coefficients } \\
\hline & & $\begin{array}{c}\text { Soil-to-Plant } \\
\mathbf{B}_{\mathbf{v}}(\mathrm{i}) \\
\text { (dimensionless) }\end{array}$ & $\begin{array}{c}\text { Grass-to-Meat } \\
\mathbf{F}_{\mathrm{b}}(\mathrm{i}) \\
(\mathrm{d} / \mathbf{k g}) \\
\end{array}$ & $\begin{array}{c}\text { Grass-to-Milk } \\
\text { F }_{\mathbf{m}}(\mathrm{i}) \\
(\mathrm{d} / \mathrm{L})\end{array}$ \\
\hline 1 & Hydrogen & 4.8 & $1.2 \times 10^{-2}$ & $1.0 \times 10^{-2}$ \\
\hline 2 & Helium & 0.0 & 0.0 & 0.0 \\
\hline 3 & Lithium & $8.3 \times 10^{-4}$ & $1.0 \times 10^{-2}$ & $5.0 \times 10^{-2}$ \\
\hline 4 & Beryllium & $4.2 \times 10^{-4}$ & $1.0 \times 10^{-3}$ & $1.0 \times 10^{-4}$ \\
\hline 5 & Boron & $1.2 \times 10^{-1}$ & $8.0 \times 10^{-4}$ & $2.7 \times 10^{-3}$ \\
\hline 6 & Carbon & 5.5 & $3.1 \times 10^{-2}$ & $1.2 \times 10^{-2}$ \\
\hline 7 & Nitrogen & 7.5 & $7.7 \times 10^{-2}$ & $2.2 \times 10^{-2}$ \\
\hline 8 & Oxygen & 1.6 & $1.6 \times 10^{-2}$ & $2.0 \times 10^{-2}$ \\
\hline 9 & Fluorine & $6.5 \times 10^{-4}$ & $1.5 \times 10^{-1}$ & $1.4 \times 10^{-2}$ \\
\hline 10 & Neon & $1.4 \times 10^{-1}$ & $2.0 \times 10^{-2}$ & $2.0 \times 10^{-2}$ \\
\hline 11 & Sodium & $5.2 \times 10^{-2}$ & $3.0 \times 10^{-2}$ & $4.0 \times 10^{-2}$ \\
\hline 12 & Magnesium & $1.3 \times 10^{-1}$ & $5.0 \times 10^{-3}$ & $1.0 \times 10^{-2}$ \\
\hline 13 & Aluminum & $1.8 \times 10^{-4}$ & $1.5 \times 10^{-3}$ & $5.0 \times 10^{-4}$ \\
\hline 14 & Silicon & $1.5 \times 10^{-4}$ & $4.0 \times 10^{-5}$ & $1.0 \times 10^{-4}$ \\
\hline 15 & Phosphorous & 1.1 & $4.6 \times 10^{-2}$ & $2.5 \times 10^{-2}$ \\
\hline 16 & Sulfur & $5.9 \times 10^{-1}$ & $1.0 \times 10^{-1}$ & $1.8 \times 10^{-2}$ \\
\hline 17 & Chlorine & 5.0 & $8.0 \times 1 C^{2}$ & $5.0 \times 10^{-2}$ \\
\hline 18 & Argon & 0.0 & 0.0 & 0.0 \\
\hline 19 & Potassium & $3.7 \times 10^{-1}$ & $1.2 \times 10^{-2}$ & $1.0 \times 10^{-2}$ \\
\hline 20 & Calcium & $3.6 \times 10^{-2}$ & $4.0: 10^{-3}$ & $8.0 \times 10^{-3}$ \\
\hline 21 & Scandium & $1.1 \times 10^{-3}$ & $1.6 \times 10^{-2}$ & $5.0 \times 10^{-6}$ \\
\hline 22 & Titanium & $5.4 \times 10^{-5}$ & $3.1 \times 10^{-2}$ & $5.0 \times 10^{-6}$ \\
\hline 23 & Vanadium & $1.3 \times 10^{-3}$ & $2.3 \times 10^{-3}$ & $1.0 \times 10^{-3}$ \\
\hline 24 & Chromium & $2.5 \times 10^{-4}$ & $2.4 \times 10^{-3}$ & $2.2 \times 10^{-3}$ \\
\hline 25 & Manganese & $2.9 \times 10^{-2}$ & $8.0 \times 10^{-4}$ & $2.5 \times 10^{-4}$ \\
\hline 26 & Iron & $6.6 \times 10^{-4}$ & $4.0 \times 10^{-2}$ & $1.2 \times 10^{-3}$ \\
\hline 27 & Cobalt & $9.4 \times 10^{-3}$ & $1.3 \times 10^{-2}$ & $1.0 \times 10^{-3}$ \\
\hline 28 & Nickel & $1.9 \times 10^{-2}$ & $5.3 \times 10^{-3}$ & $6.7 \times 10^{-3}$ \\
\hline 29 & Copper & $1.2 \times 10^{-1}$ & $8.0 \times 10^{-3}$ & $1.4 \times 10^{-2}$ \\
\hline 30 & Zinc & $4.0 \times 10^{-1}$ & $3.0 \times 10^{-2}$ & $3.9 \times 10^{-2}$ \\
\hline 31 & Gallium & $2.5 \times 10^{-4}$ & 1.3 & $5.0 \times 10^{-5}$ \\
\hline 32 & Germanium & $1.0 \times 10^{-1}$ & $2.0 \times 10^{1}$ & $5.0 \times 10^{-4}$ \\
\hline 33 & Arsenic & $1.0 \times 10^{-2}$ & $2.0 \times 10^{-3}$ & $6.0 \times 10^{-3}$ \\
\hline 34 & Selenium & 1.3 & $1.5 \times 10^{-2}$ & $4.5 \times 10^{-3}$ \\
\hline 35 & Bromine & $7.6 \times 10^{-1}$ & $2.6 \times 10^{-2}$ & $5.0 \times 10^{-2}$ \\
\hline 36 & Krypton & 0.0 & 0.0 & 0.0 \\
\hline 37 & Rubidium & $1.3 \times 10^{-1}$ & $3.1 \times 10^{-2}$ & $3.0 \times 10^{-2}$ \\
\hline 38 & Strontium & $1.7 \times 10^{-2}$ & $6.0 \times 10^{-4}$ & $8.0 \times 10^{-4}$ \\
\hline 39 & Yttrium & $2.6 \times 10^{-3}$ & $4.6 \times 10^{-3}$ & $1.0 \times 10^{-5}$ \\
\hline 40 & Zirconium & $1.7 \times 10^{-4}$ & $3.4 \times 10^{-2}$ & $5.0 \times 10^{-6}$ \\
\hline 41 & Niobium & $9.4 \times 10^{-3}$ & $2.8 \times 10^{-1}$ & $2.5 \times 10^{-3}$ \\
\hline 42 & Molybdenum & $1.2 \times 10^{-1}$ & $8.0 \times 10^{-3}$ & $7.5 \times 10^{-3}$ \\
\hline
\end{tabular}


TABLE 2.8 (Cont.)

\begin{tabular}{|c|c|c|c|c|}
\hline \multirow[b]{2}{*}{$\begin{array}{l}\text { Index } \\
\text { (i) }\end{array}$} & \multirow[b]{2}{*}{ Element } & \multicolumn{3}{|c|}{ Transfer Coefficients } \\
\hline & & $\begin{array}{c}\text { Soil-to-Plant } \\
\mathrm{B}_{\mathbf{v}}(\mathrm{i}) \\
\text { (dimensionless) }\end{array}$ & $\begin{array}{c}\text { Grass-to-Meat } \\
\text { F }_{\mathrm{b}}(\mathrm{i}) \\
(\mathrm{d} / \mathrm{kg}) \\
\end{array}$ & 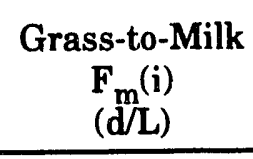 \\
\hline 43 & Technetium & $2.5 \times 10^{-1}$ & $4.0 \times 10^{-1}$ & $2.5 \times 10^{-2}$ \\
\hline 44 & Ruthenium & $5.0 \times 10^{-2}$ & $4.0 \times 10^{-1}$ & $1.0 \times 10^{-6}$ \\
\hline 45 & Rhodium & $1.3 \times 10^{1}$ & $1.5 \times 10^{-3}$ & $1.0 \times 10^{-2}$ \\
\hline 46 & Palladium & 5.0 & $4.0 \times 10^{-3}$ & $1.0 \times 10^{-2}$ \\
\hline 47 & Silver & $1.5 \times 10^{-1}$ & $1.7 \times 10^{-2}$ & $5.0 \times 10^{-2}$ \\
\hline 48 & Cadmium & $3.0 \times 10^{-1}$ & $5.3 \times 10^{-4}$ & $1.2 \times 10^{-4}$ \\
\hline 49 & Indium & $2.5 \times 10^{-1}$ & $8.0 \times 10^{-3}$ & $1.0 \times 10^{-4}$ \\
\hline 50 & Tin & $2.5 \times 10^{-3}$ & $8.0 \times 10^{-2}$ & $2.5 \times 10^{-3}$ \\
\hline 51 & Antimony & $1.1 \times 10^{-2}$ & $4.0 \times 10^{-3}$ & $1.5 \times 10^{-3}$ \\
\hline 52 & Tellurium & 1.3 & $7.7 \times 10^{-2}$ & $1.0 \times 10^{-3}$ \\
\hline 53 & Iodine & $2.0 \times 10^{-2}$ & $2.9 \times 10^{-3}$ & $6.0 \times 10^{-3}$ \\
\hline 54 & Xenon & 0.0 & 0.0 & 0.0 \\
\hline 55 & Cesium & $1.0 \times 10^{-2}$ & $4.0 \times 10^{-3}$ & $1.2 \times 10^{-2}$ \\
\hline 56 & Barium & $5.0 \times 10^{-3}$ & $3.2 \times 10^{-3}$ & $4.0 \times 10^{-4}$ \\
\hline 57 & Lanthanum & $2.5 \times 10^{-3}$ & $2.0 \times 10^{-4}$ & $5.0 \times 10^{-6}$ \\
\hline 58 & Cerium & $2.5 \times 10^{-3}$ & $1.2 \times 10^{-3}$ & $6.0 \times 10^{-4}$ \\
\hline 59 & Praseodymium & $2.5 \times 10^{-3}$ & $4.7 \times 10^{-3}$ & $5.0 \times 10^{-6}$ \\
\hline 60 & Neodymium & $2.4 \times 10^{-3}$ & $3.3 \times 10^{-3}$ & $5.0 \times 10^{-6}$ \\
\hline 61 & Promethium & $2.5 \times 10^{-3}$ & $4.8 \times 10^{-3}$ & $5.0 \times 10^{-6}$ \\
\hline 62 & Samarium & $2.5 \times 10^{-3}$ & $5.0 \times 10^{-3}$ & $5.0 \times 10^{-6}$ \\
\hline 63 & Europium & $2.5 \times 10^{-3}$ & $4.8 \times 10^{-3}$ & $5.0 \times 10^{-6}$ \\
\hline 64 & Gadolinium & $2.6 \times 10^{-3}$ & $3.6 \times 10^{-3}$ & $5.0 \times 10^{-6}$ \\
\hline 65 & Terbium & $2.6 \times 10^{-3}$ & $4.4 \times 10^{-3}$ & $5.0 \times 10^{-6}$ \\
\hline 66 & Dysprosium & $2.5 \times 10^{-3}$ & $5.3 \times 10^{-3}$ & $5.0 \times 10^{-6}$ \\
\hline 67 & Holmium & $2.6 \times 10^{-3}$ & $4.4 \times 10^{-3}$ & $5.0 \times 10^{-6}$ \\
\hline 68 & Erbium & $2.5 \times 10^{-3}$ & $4.0 \times 10^{-3}$ & $5.0 \times 10^{-6}$ \\
\hline 69 & Thulium & $2.6 \times 10^{.3}$ & $4.4 \times 10^{-3}$ & $5.0 \times 10^{-6}$ \\
\hline 70 & Ytterbium & $2.5 \times 10^{-3}$ & $4.0 \times 10^{-3}$ & $5.0 \times 10^{-6}$ \\
\hline 71 & Lutetium & $2.6 \times 10^{-3}$ & $4.4 \times 10^{-3}$ & $5.0 \times 10^{-6}$ \\
\hline 72 & Hafnium & $1.7 \times 10^{-4}$ & $4.0 \times 10^{-1}$ & $5.0 \times 10^{-6}$ \\
\hline 73 & Tantalum & $6.3 \times 10^{-3}$ & 1.6 & $2.5 \times 10^{-2}$ \\
\hline 74 & Tungsten & $1.8 \times 10^{-2}$ & $1.3 \times 10^{-3}$ & $5.0 \times 10^{-4}$ \\
\hline 75 & Rhenium & $2.5 \times 10^{-1}$ & $8.0 \times 10^{-3}$ & $2.5 \times 10^{-2}$ \\
\hline 76 & Osmium & $5.0 \times 10^{-2}$ & $4.0 \times 10^{-1}$ & $5.0 \times 10^{-3}$ \\
\hline 77 & Iridium & $1.3 \times 10^{1}$ & $1.5 \times 10^{-3}$ & $5.0 \times 10^{-3}$ \\
\hline 78 & Platinum & $5.0 \times 10^{-1}$ & $4.0 \times 10^{-3}$ & $5.0 \times 10^{-3}$ \\
\hline 79 & Gold & $2.5 \times 10^{-3}$ & $8.0 \times 10^{-3}$ & $5.0 \times 10^{-3}$ \\
\hline 80 & Mercury & $3.8 \times 10^{-1}$ & $2.6 \times 10^{-1}$ & $3.8 \times 10^{-2}$ \\
\hline 81 & Thallium & $2.5 \times 10^{-1}$ & $4.0 \times 10^{-2}$ & $2.2 \times 10^{-2}$ \\
\hline 82 & Lead & $6.8 \times 10^{-2}$ & $2.9 \times 10^{-4}$ & $6.2 \times 10^{-4}$ \\
\hline 83 & Bismuth & $1.5 \times 10^{-1}$ & $1.3 \times 10^{-2}$ & $5.0 \times 10^{-4}$ \\
\hline 84 & Polonium & $1.5 \times 10^{-1}$ & $1.2 \times 10^{-2}$ & $3.0 \times 10^{-4}$ \\
\hline 85 & Astatine & $2.5 \times 10^{-1}$ & 8.0 & $5.0 \times 10^{-2}$ \\
\hline 86 & Radon & 0.0 & 0.0 & 0.0 \\
\hline
\end{tabular}


TABLE 2.8 (Cont.)

\begin{tabular}{|c|c|c|c|c|}
\hline \multirow[b]{2}{*}{$\begin{array}{l}\text { Index } \\
\text { (i) }\end{array}$} & \multirow[b]{2}{*}{ Element } & \multicolumn{3}{|c|}{ Transfer Coefficients } \\
\hline & & $\begin{array}{c}\text { Soil-to-Plant } \\
\mathrm{B}_{\mathbf{v}}(\mathrm{i}) \\
\text { (dimensionless) }\end{array}$ & $\begin{array}{c}\text { Grass-to-Meat } \\
\mathbf{F}_{\mathrm{b}}(\mathbf{i}) \\
(\mathbf{d} / \mathbf{k g})\end{array}$ & $\begin{array}{c}\text { Grass-to-Milk } \\
F_{m}(i) \\
(d / L)\end{array}$ \\
\hline 87 & Francium & $1.0 \times 10^{-2}$ & $2.0 \times 10^{-2}$ & $5.0 \times 10^{-2}$ \\
\hline 88 & Radium & $3.1 \times 10^{-4}$ & $3.4 \times 10^{-2}$ & $8.0 \times 10^{-3}$ \\
\hline 89 & Actinium & $2.5 \times 10^{-3}$ & $6.0 \times 10^{-2}$ & $5.0 \times 10^{-6}$ \\
\hline 90 & Thorium & $4.2 \times 10^{-3}$ & $2.0 \times 10^{-4}$ & $5.0 \times 10^{-6}$ \\
\hline 91 & Protactinium & $2.5 \times 10^{-3}$ & $8.0 \times 10^{2}$ & $5.0 \times 10^{-6}$ \\
\hline 92 & Uranium & $2.5 \times 10^{-3}$ & $3.4 \times 10^{-4}$ & $5.0 \times 10^{-4}$ \\
\hline 93 & Neptunium & $2.5 \times 10^{-3}$ & $2.0 \times 10^{-4}$ & $5.0 \times 10^{-6}$ \\
\hline 94 & Plutonium & $2.5 \times 10^{-4}$ & $1.4 \times 10^{-5}$ & $2.0 \times 10^{-6}$ \\
\hline 95 & Americium & $2.5 \times 10^{-4}$ & $2.0 \times 10^{-4}$ & $5.0 \times 10^{-6}$ \\
\hline 96 & Curium & $2.5 \times 10^{-3}$ & $2.0 \times 10^{-4}$ & $5.0 \times 10^{-6}$ \\
\hline 97 & Berkelium & $2.5 \times 10^{-3}$ & $2.0 \times 10^{-4}$ & $5.0 \times 10^{-6}$ \\
\hline 98 & Californium & $2.5 \times 10^{-3}$ & $2.0 \times 10^{-4}$ & $5.0 \times 10^{-6}$ \\
\hline 99 & Einsteinium & $2.5 \times 10^{-3}$ & $2.0 \times 10^{-4}$ & $5.0 \times 10^{-6}$ \\
\hline 100 & Fermium & $2.5 \times 10^{-3}$ & $2.0 \times 10^{-4}$ & $5.0 \times 10^{-6}$ \\
\hline
\end{tabular}

Source: NRC (1977a).

\subsection{Concentrations in Meat and Milk}

Radionuclides deposited on or absorbed by hay or pasture grass can be ingested by animals whose meat is consumed by man. The equation used to estimate radionuclide concentrations in meat is

$$
C_{b}(i, t)=Q_{a} F_{b}(i) C_{v}(i, t)
$$

where:

$$
\begin{aligned}
\mathrm{C}_{\mathrm{b}}(\mathrm{i}, \mathrm{t})= & \text { average concentration of radionuclide } \mathrm{i} \text { in meat }(\mathrm{Ci} / \mathrm{kg}), \\
\mathrm{Q}_{\mathrm{a}}= & \text { feed ingestion rate }(\mathrm{kg} / \mathrm{d}), \\
\mathrm{F}_{\mathrm{b}}(\mathrm{i})= & \text { feed-to-meat transfer factor for radionuclide } \mathrm{i}(\mathrm{Ci} / \mathrm{kg} \text { per } \mathrm{Ci} / \mathrm{d} \\
& \text { ingested), and } \\
\mathrm{C}_{\mathrm{v}}(\mathrm{i}, \mathrm{t})= & \text { concentration of radionuclide in pasture grass or hay (see } \\
& \text { Equation } 2.44)(\mathrm{Ci} / \mathrm{kg}) .
\end{aligned}
$$


The equation for concentrations in milk is

$$
C_{m}(i, t)=Q_{a} F_{m}(i) C_{v}(i, t)
$$

where $C_{m}(i, t)$ equals the concentration of radionuclide $i$ in milk $(\mathrm{Ci} / \mathrm{L})$ and $F_{m}(i)$ equals the feed-to-milk radioactivity transfer factor for radionuclide $i([\mathrm{Ci} / \mathrm{L}]$ per $[\mathrm{Ci} / \mathrm{d}]$ ingested).

\subsection{Concentrations in Drinking Water}

Surface water contamination can result from the deposition of radionuclides onto the water bodies that serve as potential sources of drinking water. Contamination may also occur by rain washoff and runoff from contaminated land areas. In RISKIND, the drinking water pathway considered is via fresh surface water, which could occur within a short period (e.g., a week) following the accidental release. Other water pathways requiring a longer period - such as irrigation of farmland, water ingestion by animals that serve as food sources (milk or meat), and ingestion of aquatic food - are not included in the current version of RISKIND.

The calculation of doses from drinking water is based on a model that requires the deposition of radionuclides onto the water body, individual water consumption rates, duration of water consumption from the contaminated water body, and water treatment efficiency. In the current version of RISKIND, all materials deposited onto the water body are assumed to be thoroughly mixed with portions of or all of the water body. The removal of radionuclides by sedimentation is not considered, thus yielding a conservative estimate of the radionuclide concentrations in water.

The time-integrated radionuclide concentration in water is estimated by the following equation:

$$
\bar{C}_{w}(i, T)=G_{w}(i) F_{a} T_{w}\left[1-E_{w}(i)\right] W_{d}
$$

where:

$$
\begin{aligned}
\overline{\mathrm{C}}_{\mathrm{w}}(\mathrm{i}, \mathrm{T})= & \text { time-integrated water concentration of radionuclide } \mathrm{i} \text { at time } \mathrm{T} \\
& \left(\mathrm{Ci-yr} / \mathrm{m}^{3}\right), \\
\mathrm{G}_{\mathrm{w}}(\mathrm{i})= & \text { areal concentration of radionuclide } \mathrm{i} \text { deposited onto the water } \\
& \text { body }\left(\mathrm{Ci} / \mathrm{m}^{2}\right),
\end{aligned}
$$


$F_{a}=$ fraction of coverage of the water body by the radioactive plume,

$\left.\mathrm{T}_{\mathrm{w}}=\llbracket 1-\exp \left\{-\left[\lambda(\mathrm{i})+\lambda_{\mathrm{w}}\right] \mathrm{T}\right\}\right] /\left[\lambda(\mathrm{i})+\lambda_{\mathrm{w}}\right]$,

$\lambda_{\mathrm{w}}=$ water exchange rate $(1 / \mathrm{yr})$,

$\mathrm{E}_{\mathrm{w}}(\mathrm{i})=$ fraction of removal by the water treatment systems for radionuclide $\mathrm{i}$ (dimensionless), and

$\mathrm{W}_{\mathrm{d}}$ = effective mixing depth (m), or distance between the surface of the water body and the point of intake of the water treatment system.

In the above, the fraction of coverage $F_{a}$ is estimated by

$$
F_{a}=\left\{\begin{array}{l}
1, \text { if } F_{w} \geq 1 \\
F_{w}, \text { if } F_{w}<1
\end{array}\right.
$$

where:

$$
\begin{aligned}
& F_{w}=(2 \pi)^{1 / 2} \sigma_{y}(x) / W_{c} \\
& W_{c}=\text { crosswind width of the water body, and } \\
& \sigma_{y}(x)=\text { the dispersion parameter in the crosswind direction (at downwind } \\
& \text { distance } x \text { of the water body). }
\end{aligned}
$$

The calculated values of $F_{a}$ and $F_{w}$ are dependent on the downwind distance $(x)$ from the deposition onto the water body from the release point. The deposition concentration $G_{w}(i)$ follows Equation 2.31 for dry deposition, with a default value of $0.02 \mathrm{~m} / \mathrm{s}$ for $V_{d}$, and Equation 2.37 for wet deposition. The removal efficiency of the water treatment system $\left(\mathrm{E}_{\mathrm{w}}\right)$ depends on the effectiveness of removing the radionuclides in the water treatment plant; $\mathrm{E}_{\mathrm{w}}$ is 0 if no water treatment is considered.

\subsection{Time-Integrated Concentrations}

To estimate total doses over the exposure time of interest, equations ( 2.46 to 2.52 ) that were derived for environmental media concentrations are integrated over the total exposure time for an individual. The results are the time-integrated environmental media 
concentrations. These time-integrated concentrations are used to assess the doses to an individual over the total exposure time of interest. The time-integrated environmental media concentrations from the time of release $(t=0)$ to a particular time of interest $(t=T)$ can be expressed as follows:

$$
\begin{aligned}
& \bar{C}_{g}(i, T)=C_{g}(i, 0) T_{g}(i, T) \\
& \overline{\mathrm{C}}_{\mathrm{r}}(\mathrm{i}, \mathrm{T})= \begin{cases}\text { FI C }(\mathrm{i}, 0) \mathrm{T}_{\mathrm{r}}(\mathrm{i}, \mathrm{T}), & \mathrm{T} \leq \mathrm{T}_{\mathrm{a}} \\
\mathrm{FI} \mathrm{C}_{\mathrm{g}}(\mathrm{i}, 0) \mathrm{T}_{\mathrm{r}}(\mathrm{i}, \mathrm{T})+\mathrm{FE}\left[\overline{\mathrm{C}}_{\mathrm{g}}(\mathrm{i}, \mathrm{T})-\overline{\mathrm{C}}_{\mathrm{g}}(\mathrm{i}, \mathrm{T} \mathrm{a})\right], & \mathrm{T}>\mathrm{T}_{\mathrm{a}}\end{cases} \\
& \overline{\mathrm{C}}_{\mathrm{v}}(\mathrm{i}, \mathrm{T})=\overline{\mathrm{C}}_{\mathrm{g}}(\mathrm{i}, \mathrm{T}) \mathrm{S}_{\mathrm{v}}(\mathrm{i})+\overline{\mathrm{C}}_{\mathrm{r}}(\mathrm{i}, \mathrm{T}) \mathrm{A}_{\mathrm{v}}(\mathrm{i}) \\
& \overline{\mathrm{C}}_{\mathrm{b}}(\mathrm{i}, \mathrm{T})=\overline{\mathrm{C}}_{\mathrm{v}}(\mathrm{i}, \mathrm{T}) \mathbf{Q}_{\mathrm{a}} \mathrm{F}_{\mathrm{b}}(\mathrm{i}) \\
& \overline{\mathrm{C}}_{\mathrm{m}}(\mathrm{i}, \mathrm{T})=\overline{\mathrm{C}}_{\mathrm{v}}(\mathrm{i}, \mathrm{T}) \mathbf{Q}_{\mathrm{a}} \mathrm{F}_{\mathrm{m}}(\mathrm{i})
\end{aligned}
$$

where:

$$
\begin{aligned}
& \overline{\mathrm{C}}_{\mathrm{g}}(\mathrm{i}, \mathrm{T})=\text { time-integrated ground }(\mathrm{g}) \text { concentration for radionuclide } \mathrm{i} \text { at } \\
& \text { time } \mathrm{T} \text { following a release }\left(\mathrm{Ci}-\mathrm{s} / \mathrm{m}^{2}\right) \text {, } \\
& \mathrm{T}_{\mathrm{g}}(\mathrm{i}, \mathrm{T})=\llbracket 1-\exp \left\{-\left[\lambda(\mathrm{i})+\lambda_{\mathrm{g}}\right] \mathrm{T}\right\} \mathbb{y}\left[\lambda(\mathrm{i})+\lambda_{\mathrm{g}}\right], \\
& \overline{\mathrm{C}}_{r}(\mathrm{i}, \mathrm{T})=\text { time-integrated air concentration for resuspension ( } \mathrm{r} \text { ) for } \\
& \text { radionuclide } i \text { at time } \mathrm{T}\left(\mathrm{Ci}-\mathrm{s} / \mathrm{m}^{3}\right) \text {, } \\
& \mathrm{T}_{\mathrm{r}}(\mathrm{i}, \mathrm{T})=\llbracket 1-\exp \left[-\left[\lambda(\mathrm{i})+\lambda_{\mathrm{g}}+\lambda_{\mathrm{r}}\right] \mathrm{T}\right] \mathbb{V}\left[\lambda(\mathrm{i})+\lambda_{\mathrm{g}}+\lambda_{\mathrm{r}}\right] \\
& \overline{\mathrm{C}}_{\mathrm{v}}(\mathrm{i}, \mathrm{T})=\text { time-integrated concentration in vegetation (v) for } \\
& \text { radionuclide } \mathrm{i} \text { at time } \mathrm{T}(\mathrm{Ci}-\mathrm{s} / \mathrm{kg}) \text {, } \\
& \overline{\mathrm{C}}_{\mathrm{b}}(\mathrm{i}, \mathrm{T})=\text { time-integrated concentration in meat }(\mathrm{b}) \text { for radionuclide } \mathrm{i} \text { at } \\
& \text { time } \mathrm{T}(\mathrm{Ci}-\mathrm{s} / \mathrm{kg}) \text {, and } \\
& \overline{\mathrm{C}}_{\mathrm{m}}(\mathrm{i}, \mathrm{T})=\text { time-integrated concentration in milk }(\mathrm{m}) \text { for radionuclide } \mathrm{i} \text { at } \\
& \text { time T (Ci-s/L). }
\end{aligned}
$$


Parameter $\mathrm{C}_{\mathrm{g}}(\mathrm{i}, 0)$ can be calculated by Equation 2.31 and/or $2.37 ; \mathrm{S}_{\mathrm{v}}(\mathrm{i})$ and $\mathrm{A}_{\mathrm{v}}(\mathrm{i})$ are as defined in Equation 2.50; $Q_{a}$ and $F_{b}$ are as defined in Equation 2.51; and $F_{m}$ is defined in Equation 2.52.

\subsubsection{Long-Term Dose Models}

The long-term dose from a given release is calculated by integrating the dose over a period of $\mathrm{T}$ equals $50 \mathrm{yr}$ (default) following the release. Doses to individuals are calculated for all known significant exposure pathways. These exposure pathways include inhalation; external exposure to air and ground contamination; and ingestion of vegetables, meat, and milk. Internal doses from inhalation or ingestion pathways are calculated with dose conversion factors. Because radionuclides taken into the body by ingestion or inhalation will continue to irradiate the body as long as they exist and are retained by the body, these internal dose conversion factors represent the committed dose (ICRP 1977), which is the dose integrated over an interval of 50 years.

\subsection{Inhalation Doses from Resuspended Air Concentrations}

Inhalation doses to individuals are calculated with time-integrated air concentrations

from resuspension, $\overline{\mathrm{C}}_{\mathrm{r}}$, which are determined from Equation 2.57 and the 50-year committed inhalation dose conversion factors (EPA 1988).

Inhalation doses are calculated by the following equation:

$$
D_{r_{I n h}}=\sum_{i} \bar{C}_{r}(i, T) \cdot D F_{I n h}(i) \cdot B_{r}
$$

where:

$$
\begin{aligned}
& D_{r_{\text {Inh }}}=\text { inhalation dose due to resuspended air contamination (mrem), } \\
& \overline{\mathbf{C}}_{\mathrm{r}}(\mathrm{i}, \mathrm{T})=\text { time-integrated resuspended air concentration of radionuclide } \mathrm{i} \\
& \left(\mathrm{Ci}-\mathrm{s} / \mathrm{m}^{3}\right) \text {, } \\
& \mathrm{DF}_{\mathrm{Inh}}(\mathrm{i})=\text { inhalation dose conversion factor for radionuclide } \mathrm{i}(\mathrm{mrem} / \mathrm{Ci}) \text {, } \\
& \text { and } \\
& B_{r}=\text { breathing rate (default: } 2.3 \times 10^{-4} \mathrm{~m}^{3} / \mathrm{s} \text { ). }
\end{aligned}
$$




\subsection{External Doses from Resuspended Air Concentrations}

External radiation doses received from resuspended air concentrations are calculated as the product of the time-integrated air concentration from resuspension and the cloud gamma dose conversion factor:

$$
\mathrm{D}_{\mathrm{r}_{\mathrm{Exa}}}=\mathrm{K}_{1} \sum_{\mathrm{i}} \overline{\mathrm{C}}_{\mathrm{r}}(\mathrm{i}, \mathrm{T}) \cdot \mathrm{DF} \mathrm{Exa}_{\mathrm{Ex}}(\mathrm{i})
$$

where:

$$
\begin{aligned}
\mathrm{D}_{\mathrm{r}_{\mathrm{Ex}}}= & \text { dose received from exposure to the resuspended air } \\
& \text { concentration }(\mathrm{mrem}), \\
\mathrm{K}_{1}= & \text { conversion constant }\left(2.78 \times 10^{-4} \mathrm{~h} / \mathrm{s}\right) \text {, and } \\
\mathrm{DF}_{\mathrm{Exa}}(\mathrm{i})= & \text { cloud dose factor }\left(\mathrm{mrem} / \mathrm{h} \text { per } \mathrm{Ci} / \mathrm{m}^{3}\right) \text { for radionuclide } \mathrm{i} .
\end{aligned}
$$

The cloud dose conversion factors are those given in the DOE report on conversion factors for calculation of doses to the public (DOE 1988).

\subsection{External Exposure from Ground-Deposited Radionuclides}

Radioactively contaminated ground provides a long-term source of gamma radiation for individuals residing near the contamination. For long-term exposure, the time-integrated external doses from radioactive material deposited on the ground are calculated as the

product of $\overline{\mathrm{C}}_{\mathrm{g}}$, the time-integrated ground concentration from Equation 2.56, and the ground dose conversion factor:

$$
D_{g_{E x g}}=K_{1} \sum_{i} \bar{C}_{g}(i, T) D F_{E x g}(i)
$$

where:

$$
\begin{aligned}
D_{\mathbf{E}_{\mathrm{Exg}}}= & \text { dose received from exposure to the ground (mrem), } \\
\mathrm{K}_{1}= & \text { unit conversion constant }\left(2.78 \times 10^{-4} \mathrm{~h} / \mathrm{s}\right), \\
\overline{\mathrm{C}}_{\mathrm{g}}(\mathrm{i}, \mathrm{T})= & \text { integrated ground concentration }\left(\mathrm{Ci}-\mathrm{s} / \mathrm{m}^{2}\right) \text {, and } \\
\mathrm{DF}_{\mathrm{Exg}}(\mathrm{i})= & \text { dose conversion factor from ground exposure for radionuclide } \mathrm{i} \\
& \left(\mathrm{mrem} / \mathrm{h} \text { per } \mathrm{Ci} / \mathrm{m}^{2}\right) .
\end{aligned}
$$


The dose conversion factors used for this mode of exposure are also taken from the DOE report on conversion factors for calculation of doses to the public (DOE 1988). These factors were derived for a point $1 \mathrm{~m}$ above an infinite plane surface. Shielding from structures can be accounted for by use of a shielding factor.

\subsection{Ingestion Doses from Agricultural Products}

Ingestion doses are calculated for vegetables, meat, and milk and are based on the time-integrated concentrations calculated from Equations 2.56 through 2.60, ingestion dose conversion factors (EPA 1988), and ingestion rates (NRC 1977a).

Vegetable ingestion doses are calculated by

$$
D_{\text {veg }}=K_{2} 0.5 U_{v} \sum_{i} \bar{C}_{v}(i, T) D F_{\text {Ing }}(i)
$$

where:

$$
\begin{aligned}
\mathrm{D}_{\mathrm{veg}}= & \text { fresh vegetable ingestion dose (mrem), } \\
\mathrm{K}_{2}= & \text { unit conversion factor }\left(3.17 \times 10^{-8} \mathrm{yr} / \mathrm{s}\right), \\
0.5= & \text { fraction of initial radioactivity in a vegetable after preparation } \\
& \text { for consumption (NRC } 1977 \mathrm{a}), \\
\mathrm{U}_{\mathrm{v}}= & \text { ingestion rate of vegetables }(281 \mathrm{~kg} / \mathrm{yr}), \\
\overline{\mathrm{C}}_{\mathrm{v}}(\mathrm{i}, \mathrm{T})= & \text { time-integrated concentration of radionuclide } \mathrm{i} \text { in vegetable } \\
& (\text { Ci-s/kg), and } \\
\mathrm{DF}_{\text {Ing }}(\mathrm{i})= & \text { ingestion dose conversion factor for radionuclide } \mathrm{i}(\mathrm{mrem} / \mathrm{Ci}) .
\end{aligned}
$$

Doses from meat ingestion are calculated by

$$
D_{\text {meat }}=K_{2} U_{b} \sum_{i} \bar{C}_{b}(i, T) D F_{\text {Ing }}(i)
$$

where:

$$
\begin{aligned}
\mathrm{D}_{\text {meat }} & =\text { meat ingestion dose }(\mathrm{mrem}) \\
\mathrm{K}_{2} & =\text { unit conversion factor }\left(3.17 \times 10^{-8} \mathrm{yr} / \mathrm{s}\right), \\
\mathrm{U}_{\mathrm{b}} & =\text { meat ingestion rate }(110 \mathrm{~kg} / \mathrm{yr}), \text { and } \\
\overline{\mathrm{C}}_{\mathrm{b}}(\mathrm{i}, \mathrm{T}) & =\text { time-integrated concentration of radionuclide i in meat }(\mathrm{Ci}-\mathrm{s} / \mathrm{kg}) .
\end{aligned}
$$


The dose to an individual from milk ingestion is given by

$$
\mathrm{D}_{\text {milk }}=\mathrm{K}_{2} \mathrm{U}_{\mathrm{m}} \sum_{\mathrm{i}} \overline{\mathrm{C}}_{\mathrm{m}}(\mathrm{i}, \mathrm{T}) \mathrm{DF}_{\text {Ing }}(\mathrm{i})
$$

where:

$$
\begin{aligned}
\mathrm{D}_{\text {milk }} & =\text { milk ingestion dose }(\mathrm{mrem}), \\
\mathrm{K}_{2} & =\text { unit conversion factor }\left(3.17 \times 10^{-8} \mathrm{yr} / \mathrm{s}\right), \\
\mathrm{U}_{\mathrm{m}} & =\text { milk ingestion rate }(310 \mathrm{~L} / \mathrm{yr}) \text {, and } \\
\overline{\mathrm{C}}_{\mathrm{m}}(\mathrm{i}, \mathrm{T}) & =\text { time-integrated concentration of radionuclide } \mathrm{i} \text { in milk }(\mathrm{Ci}-\mathrm{s} / \mathrm{L}) .
\end{aligned}
$$

\subsection{Ingestion Doses from Drinking Water}

The dose to an individual from drinking contaminated surface water is calculated by

$$
D_{\text {water }}=U_{w} \sum_{i} \bar{C}_{w}(i, T) D F_{\text {Ing }}(i)
$$

where:

$$
\begin{aligned}
\mathrm{D}_{\text {water }}= & \text { drinking water ingestion dose (mrem), } \\
\mathrm{U}_{\mathrm{w}}= & \text { water intake rate by an individual }(\mathrm{L} / \mathrm{yr}), \\
\overline{\mathrm{C}}_{\mathrm{w}}(\mathrm{i}, \mathrm{T})= & \text { time-integrated concentration of radionuclide } \mathrm{i} \text { in surface } \\
& \text { water }(\mathrm{Ci} / \mathrm{L})(\text { see Equation } 2.53), \text { and } \\
\mathrm{DF}_{\text {Ing }}(\mathrm{i})= & \text { ingestion dose conversion factor for radionuclide } \mathrm{i}(\mathrm{mrem} / \mathrm{Ci}) .
\end{aligned}
$$

Total long-term ingestion doses are obtained by summing the vegetable, meat, and milk ingestion doses per the following equation:

$$
D_{\text {Ing }}=D_{\text {veg }}+D_{\text {meat }}+D_{\text {milk }}+D_{\text {water }}
$$

where $D_{\text {Ing }}$ equals the total time-integrated ingestion dose (mrem) up to a total time period of concern, $\mathrm{T}$. Currently the default value of $\mathrm{T}$ in RISKIND is 50 years for individual dose calculations. 


\subsection{Analysis of Weather Uncertainty on Individual Doses}

Weather conditions and their frequency of occurrence at a site can be characierized by site-specific wind-rose data. The uncertainty of the effect of weather conditions during an accident on the calculated individual dose consequences is estimated by constructing a cumulative probability distribution of dose values by using seasonal or annual wind jointfrequency data for a given region. This probabilistic dose distribution is then used to determine the "median" (50\% weather probability) and reasonable "maximum" (95\% weather probability) dose values for each receptor of interest.

\subsubsection{Population Dose Model}

A population dose model was developed for RISKIND to assess the potential collective doses to the exposed population as the result of a release associated with a spent nuclear fuel transportation accident. The population dose model implemented in RISKIND calculates not only the total collective dose but also the average individual dose and the distribution of doses in the exposed population within the specific area of interest.

To calculate the distribution of radiation doses in the exposed population from a release, the areas and magnitudes of air concentration in the downwind direction are needed. The atmospheric dispersion model described in Section 2.2.2 for calculating individual receptor radionuclide concentrations was expanded to calculate these parameters. The approach implemented in RISKIND for estimating the area and concentration parameters is given in Sections 2.2.3.1 and 2.2.3.2.

\subsubsection{Concentration Isopleth and Contaminated Areas}

The time-integrated ground-level air concentration $\overline{\mathbf{C}}_{\mathrm{a}}$ at a downwind location $(\mathbf{x}, \mathbf{y})$ is calculated on the basis of the equations in Section 2.2.2.1. For a given air concentration, $\overline{\mathrm{C}}_{\mathrm{a}}$, the isopleth contour $\mathrm{y}(\mathrm{x})$ can be derived from either Equation 2.13 or 2.14. At downwind

distances not affected by the presence of a mixing layer, $\overline{\mathrm{C}}_{\mathrm{a}}$ can be derived from Equation 2.13 as

$$
y(x)= \pm \sigma_{y}\left[2 \ln \left(\frac{Q_{x}}{\pi \sigma_{y} \sigma_{z} u \bar{C}_{a}}\right)-\left(\frac{H}{\sigma_{z}}\right)^{2}\right]^{1 / 2}
$$


At downwind distences where total mixing by the presence of a mixing layer can be assumed, $\overline{\mathrm{C}}_{\mathrm{a}}$ can be derived from Equation 2.14 as

$$
y(x)= \pm \sigma_{y}\left[2 \ln \left(\frac{Q_{x}}{\sqrt{2 \pi} \sigma_{y} u L \bar{C}_{a}}\right)\right]^{1 / 2}
$$

At downwind distances between the nonmixing (Equation 2.69) and the total mixing (Equation 2.70) conditions, $y(x)$ is determined by a linear interpolation between Equations 2.69 and 2.70 .

The area of contamination, $\mathrm{A}$, for a given time-integrated air concentration level, $\overline{\mathrm{C}}_{\mathrm{a}}$, can then be calculated by

$$
A=2 \int_{x_{1}}^{x_{2}} y(x) d x
$$

where $\mathrm{X}_{1}$ and $\mathrm{X}_{2}$ are the minimum and maximum downwind distances bounding the population or agricultural region of interest. The parameters $X_{L}$ and $X_{R}$ (Figure 2.5), which are obtained by setting $y=0$ in Equation 2.69 or 2.70, are the shortest and longest downwind centerline distances for each concentration contour. Equation 2.71 is integrated numerically in RISKIND by using a Simpson's rule integration routine.

The area corresponding to a preselected air concentration value for a given release condition can be calculated by Equation 2.71. A set of 20 preselected relative ground-level air concentration values, $\overline{\mathrm{C}}_{\mathrm{a}}$, is used in RISKIND to calculate the concentration contours for the areas of contamination. These relaiive air concentrations are provided in Table 2.9. For a specific weather zondition defined by a stability class, s, and a wind speed, u, Equation 2.71 is used to calculate the area, $A_{j}(s, u)$, that contains a time-integrated relative air concentration equal to or smaller than a specific value, $\overline{\mathbf{C}}_{j}$. For successively descending time-integrated relative air concentration levels $\left(\overline{\mathrm{C}}_{1}, \overline{\mathrm{C}}_{2}, \ldots, \overline{\mathrm{C}}_{20}\right)$, a series of nested areas $\left(\bar{A}_{1}=A_{1}-A_{2}, \bar{A}_{2}=A_{2}-A_{3} \ldots\right)$ as shuwn in Figure 2.5 are calculated. Up to 20 areas, each ar a corresponding to a concentration contour, can be calculated for the release conditions described by an appropriate accident response region (as described in Section 2.2.1). 


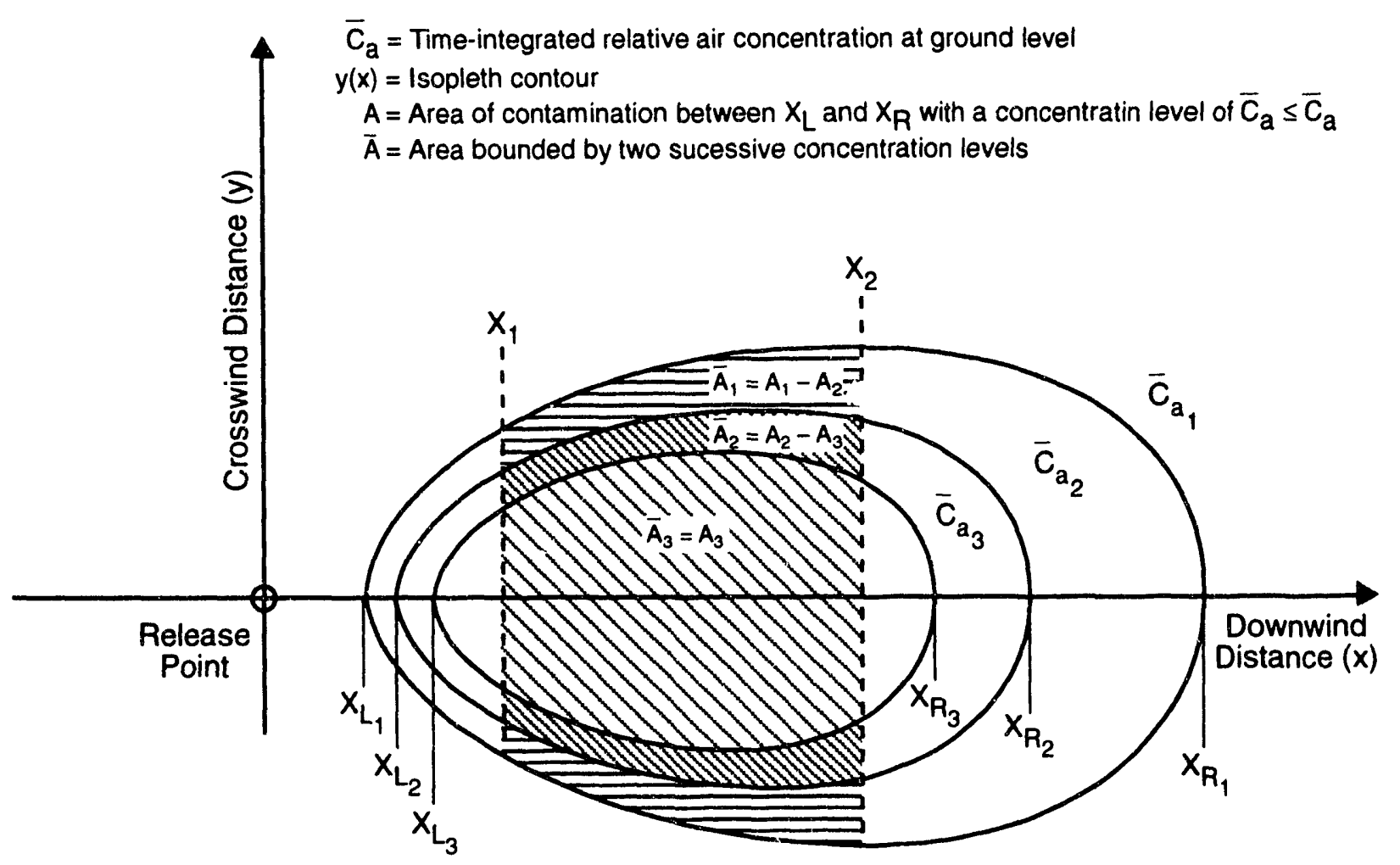

FIGURE 2.5 Areas of Air Concentration Contours for Population Dose Calculation

\subsubsection{Dose Models}

Once the sizes of the 20 nested areas are determined, collective population doses can be calculated. Collective doses are calculated only for the specific population or agricultural region of interest. The region of interest is the area confined by the two input distances $\mathrm{X}_{1}$ and $\mathrm{X}_{2}$, which represent the minimum and maximum downwind distances of interest from the release point (Section 2.2.3.1). Inhalation and external doses to the population within these two bounding distances are calculated by the following procedures.

For each nested interval $\left(\bar{A}_{j}\right)$ confined by two time-integrated relative concentration contours $(j$ and $j+1)$, doses to the average individual are calculated by using the geometric mean relative air concentration values within the area as

$$
\begin{aligned}
& \hat{C}_{g j}=\sqrt{\bar{C}_{g j} \bar{C}_{g j+1}} \\
& \hat{C}_{a j}=\sqrt{\bar{C}_{a j} \bar{C}_{a j+1}}
\end{aligned}
$$


TABLE 2.9 Default Time-Integrated Relative Ground-Level Air Concentration Limits Used to Calculate Contaminated Areas

\begin{tabular}{cc}
\hline $\begin{array}{c}\text { Contamination } \\
\text { Level } \\
(\mathrm{j})\end{array}$ & $\begin{array}{c}\text { Time-Integrated } \\
\text { Relative Air } \\
\text { Concentration } \\
(\overline{\mathrm{C}})\end{array}$ \\
\hline 1 & 1.00 \\
2 & $3.00 \times 10^{-1}$ \\
3 & $1.00 \times 10^{-2}$ \\
4 & $3.30 \times 10^{-2}$ \\
5 & $1.00 \times 10^{-3}$ \\
6 & $3.33 \times 10^{-3}$ \\
7 & $1.00 \times 10^{-3}$ \\
8 & $3.33 \times 10^{-4}$ \\
9 & $1.00 \times 10^{-4}$ \\
10 & $3.33 \times 10^{-5}$ \\
11 & $1.00 \times 10^{-5}$ \\
12 & $3.33 \times 10^{-6}$ \\
13 & $1.00 \times 10^{-6}$ \\
14 & $3.33 \times 10^{-7}$ \\
15 & $1.00 \times 10^{-7}$ \\
16 & $3.33 \times 10^{-8}$ \\
17 & $1.00 \times 10^{-8}$ \\
18 & $3.33 \times 10^{-9}$ \\
19 & $1.00 \times 10^{-9}$ \\
20 & $3.33 \times 10^{-10}$ \\
\hline
\end{tabular}

where:

$\hat{C}_{\mathrm{aj}}=$ mean relative time-integrated air concentration inside $\overline{\mathrm{A}}_{\mathrm{j}}$,

$\overline{\mathrm{C}}_{\mathrm{aj}}=$ time-integrated relative air concentration at concentration contour $j$,

$\hat{C}_{\mathrm{gj}}=$ mean relative ground surface concentration inside $\overline{\mathrm{A}}_{\mathrm{j}}$, and

$\overline{\mathrm{C}}_{\mathrm{gj}}=$ relative ground surface concentration at concentration contour $\mathrm{j}$. 
The mean time-integrated air concentration for radionuclide $i$ inside $\bar{A}_{j}$ is then calculated by multiplying the mean relative time-integrated air concentration $\overline{\mathrm{C}}_{\mathrm{aj}}$ by the source term of radionuclide $i$, or $Q(i)$, as

$$
\hat{C}_{a j}(i)=Q(i) \hat{C}_{a j}
$$

Similarly, the mean ground surface concentration for radionuclide $i$ inside $\bar{A}_{j}$ is calculated by

$$
\hat{C}_{g(i)}(\mathbf{i}) \mathrm{Q}(\mathrm{i}) \hat{C}_{\mathrm{gj}}
$$

Once the radionuclide concentrations are determined, the average individual doses (Dj) for both the short-term and long-term exposure periods are calculated by using the same approach as that described in Sections 2.2.2.3 and 2.2.2.4. These average doses are then multiplied by the population $(\mathrm{Pj})$ calculated within the nested interval $(\mathrm{j})$ by

$$
\mathrm{Pj}=\operatorname{PD} \overline{\mathbf{A}}_{\mathbf{j}}
$$

where:

$$
\begin{aligned}
\mathrm{Pj} & =\text { population residing in nested area } \overline{\mathrm{A}}_{\mathrm{j}} \text { (persons), } \\
\mathrm{PD} & =\text { population density within the region of interest }\left(\text { persons } / \mathrm{m}^{2}\right), \text { and } \\
\bar{A}_{j} & =\text { area of nested area } j\left(\mathrm{~m}^{2}\right) .
\end{aligned}
$$

The total collective dose is then calculated as the sum over all nested intervals:

$$
\operatorname{PDOSE}=\sum_{j}\left(D_{j} \mathrm{Pj}\right)
$$

where:

PDOSE $=$ collective dose in the region $\left(\mathrm{X}_{1}\right.$ to $\left.\mathrm{X}_{2}\right)$ of interest (person-rem), and

$\mathrm{Dj}=$ average individual dose for nested area $\bar{A}_{j}$ (rem). 
The population dose from inhalation and external exposure within $\bar{A}_{j}$ is calculated by

$$
\left.\operatorname{PDOSE}_{(I n h}+E x t\right)=\sum_{j} P j\left(D j_{I n h}+D j_{E x t}\right)
$$

where:

$$
\begin{aligned}
\left.\operatorname{PDOSE}_{(I n h}+E x t\right)= & \text { collective dose from inhalation and external pathways } \\
& \text { (person-rem), } \\
D_{j_{\text {Inh }}=} & \text { average individual dose from inhalation pathway in } \\
& \text { nested interval } \bar{A}_{j}(\text { rem), and } \\
D_{j_{E x t}=} & \text { average individual dose from external radiation in the } \\
& \text { air and on the ground (rem). }
\end{aligned}
$$

\subsection{Ingestion Dose Models}

The total collective dose from ingestion pathways is calculated on the basis of regional agricultural productivity rather than population because the total radioactive contamination in the food determines the potential collective doses rather than the number of persons exposed. Ingestion population doses are calculated by using the following procedures.

The annual productivity ( $\mathrm{kg} / \mathrm{km}^{2}-\mathrm{yr}$ or $\mathrm{L} / \mathrm{km}^{2}$-yr) of each food category (vegetables, meat, and milk) is assigned by the user; these productivity values can be either site-specific data or the default state average values. For each nested interval, the mean radionuclide concentrations in each food type are calculated by using the same approach as that of Section 2.2.3. These concentration values are then multiplied by the farm production rate and the farm area nested to find the total radioactive contamination in each food for each area $\left(\overline{\mathrm{A}}_{\mathrm{j}}\right)$. Collective doses are then determined by assuming that either all or a fraction of the food produced in the contaminated region of interest is eventually consumed.

The collective doses from ingestion are calculated with the following equations. First, the gross radioactive contamination in each food type is calculated by

$$
Q_{f}(i)=\frac{\sum_{j} G_{f} \bar{A}_{j} F_{a} \bar{C}_{f}(i, j)}{F D_{j}}
$$


where:

$$
\begin{aligned}
Q_{f}(i)= & \text { gross radioactive content of radionuclide } i \text { in food } f(C i) ; \\
\bar{A}_{j}= & \text { area of nested interval } j\left(\mathrm{~km}^{2}\right) ; \\
F_{a}= & \text { fraction of land that is farmland; } \\
\bar{C}_{f}(i, j)= & \text { concentration of radionuclide } i \text { in nested area } j \text { in food type } f \\
& \text { where } f \text { represents } m \text { for milk, b for meat, and } v \text { for vegetables } \\
& (\text { Ci/kg or } \mathrm{Ci} / \mathrm{L}) ; \\
G_{f}= & \text { farm production rate of food type f inside } \mathrm{X}_{1} \text { and } \mathrm{X}_{2}\left(\mathrm{~kg} / \mathrm{yr}-\mathrm{km}^{2}\right. \\
& \text { or } \left.\mathrm{L} / \mathrm{yr}-\mathrm{km}^{2}\right) ; \text { and } \\
\mathrm{FD}_{\mathrm{j}}= & \text { decontamination factor calculated for nested interval } \mathrm{j} .
\end{aligned}
$$

$\mathrm{FD}_{\mathrm{j}}$ is estimated from the following equation:

$$
\mathrm{FD}_{\mathrm{j}}=\frac{\mathrm{DI}_{(\mathrm{Inh}+\text { Ext }+ \text { Ing) }}(\mathrm{j})}{\text { PAG }}
$$

where:

$$
\begin{aligned}
\mathrm{DI}_{(\mathrm{Inh}+\text { Ext+Ing) }}(\mathrm{j})= & \text { average individual dose from all three pathways } \\
& \text { (inhalation, external, and ingestion) in nested area } \overline{\mathrm{A}}_{\mathbf{j}}, \\
& \text { and } \\
\text { PAG }= & \text { EPA protective action guide dose value (EPA 1991) } \\
& (\text { e.g., 5-rem, 50-yr time-integrated dose). }
\end{aligned}
$$

$F D_{j}$ has a value of greater than or equal to 1 . If the calculated $F D_{j}$ is less than 1.0 , no decontamination is necessary for nested interval $\bar{A}_{j}$, and $F D_{j}$ is made equal to 1 .

The collective ingestion dose from all food categories is calculated by

$$
\operatorname{PDOSE}_{\text {Ing }}=\sum_{\mathrm{f}} \sum_{\mathrm{i}} \mathrm{U}_{\mathrm{f}} \mathrm{Q}_{\mathrm{f}}(\mathrm{i}) \mathrm{DF}_{\mathrm{Ihg}}(\mathrm{i})
$$


where:

$\mathrm{PDOSE}_{\mathrm{Ing}}=$ collective dose from ingestion of contaminated foodstuff, and

$\mathrm{DF}_{\text {Ing }}(\mathrm{i})=$ ingestion dose conversion factor $(\mathrm{rem} / \mathrm{Ci})$.

\subsection{Population Drinking Water Dose}

Radionuclide concentrations in drinking water for the individual drinking water pathway are calculated by using Equation 2.67. However, the locations of water bodies that can serve as potential sources of drinking water for the population need to be identified. The collective dose is calculated as the sum over all water bodies as

$$
\operatorname{PDOSE}_{\text {water }}=\sum_{k} D_{\text {water }}(k) P_{\text {water }}(k)
$$

where:

$$
\begin{aligned}
\mathrm{PDOSE}_{\text {water }}= & \text { collective dose from drinking water (person-rem), } \\
\mathrm{D}_{\text {water }}(\mathrm{k})= & \text { average individual dose calculated for water body }(\mathbf{k}) \\
& \text { (Equation } 2.67), \text { and } \\
\mathrm{P}_{\text {water }}(\mathrm{k})= & \text { number of people consuming drinking water from water } \\
& \text { body } \mathrm{k} .
\end{aligned}
$$

\subsection{Analysis of Weather Uncertainty on Population Dose}

The uncertainty of the effect of weather conditions during an accident on the calculated collective dose consequences should be assessed. This uncertainty is estimated by constructing a cumulative probability distribution of dose values from the wind-rose data for a given site. This probabilistic dose distribution is then used to determine the "median" ( $50 \%$ weather probability) and reasonable "maximum" (95\% weather probability) dose values for the region of interest. 


\section{HEALTH EFFECTS MODELS}

\subsection{EARLY EFFECTS}

A health effects model was developed for early (acute) effects of exposure to radiation that could be associated with spent nuclear fuel transportation accidents. The model applies to potential accident conditions in which individuals would be exposed to relatively large doses in a short period. The early effects considered in the model include acute effects that normally occur within the first year after radiation exposure. The model is based on the NRC health effects study (NRC 1989; Abrahamson et al. 1989, 1991). Only early fatalities due to acute irradiation are considered in RISKIND. Three possible modes of fatality are modeled: fatality associated with injury to (1) bone marrow, (2) gastrointestinal tract, and (3) lungs. Two types of dose responses are used for modeling the levels of medical treatment - minimal and supportive. Options are provided for bounding model parameters at three estimation levels - lower, central, and upper - to compensate for uncertainty associated with the model.

Two basic categories of exposure are considered: (1) sudden exposure primarily due to external gamma rays from a passing radioactive cloud, the radionuclide-contaminated ground surface, or loss of cask shielding; and (2) protracted internal exposure from inhaled radionuclides. For radiation exposure resulting from spent nuclear fuel transportation accidents, the first exposure category is usually not as significant as the second because spent nuclear fuels generally contain a significant portion of radionuclides that can potentially deliver internal doses over a longer period of time after intake.

The early effects of exposure are generally associated only with relatively high radiation doses; the severity of these effects diminishes with smaller radiation doses. This dose-response relationship implies a dose threshold below which no early effects are apparent. For the health risk calculation, radiation dose refers to the average absorbed dose to the specific organ of interest. For external radiation, whole-body exposure is assumed. Dose rate refers to the average absorbed dose rate to the target of interest over a specified time period.

A hazard-function approach was used to derive risk estimates for effects in three organs of the body and to determine the total risk resulting from the exposure of these three 
organs. The risk is calculated from the cumulative hazard H (NRC 1989). (In this section, the term risk represents the chance of fatality or health effect resulting from an incurred radiation dose.) The general expression used for the lethal hazard $\left(\mathrm{H}_{\mathrm{A}}\right)$ is a two-parameter Weibull function as follows:

$$
H_{A}=\ln (2) X^{v}
$$

where:

$$
\begin{aligned}
X= & D / D_{50} ; \\
D= & \text { radiation (average absorbed) dose; } \\
D_{50}= & \text { median lethal dose, that is, the dose that produces the effect of } \\
& \text { interest in } 50 \% \text { of the population at risk; and } \\
\mathbf{v}= & \text { parameter for shape that determines the shape of the dose-effect } \\
& \text { curve. }
\end{aligned}
$$

The risk of lethality is related to $\mathrm{H}_{\mathrm{A}}$ by the expression (NRC 1989)

$$
\text { Risk }=1-\exp \left(-H_{A}\right)
$$

Because $D_{50}$ is a function of dose rate $\dot{D}$ and, therefore, a function of time, the total $X$ is obtained by integration over the total exposure time $t_{0}$ :

$$
X=\int_{0}^{t_{0}} \dot{D}(t) / \dot{D}_{50}(D) d t
$$

where $\dot{D}$ is the absorbed dose rate to the organ of interest as evaluated at exposure time $t$. Suitable models and model parameters are currently not available for all lethal effects using the exact form of Equation 3.1. A simplified fixed-parameter approach is used in the NRC health effects study (Abrahamson et al. 1989, 1991). In this approach, the model parameter $\mathrm{D}_{50}$ is assumed to change only when the dose rate enters specific dose-rate ranges. Two values of $\mathrm{D}_{50}$ are defined: one for brief high-dose rates, the other for protracted low-dose rates. The cutoff between the brief high-dose rate and the protracted low-dose rate is $0.06 \mathrm{~Gy} / \mathrm{h}$, or $0.1 \mathrm{rad} / \mathrm{min}$. This value is based on an exploratory analysis of limited data regarding the influence of dose on $D_{50}$. 
To calculate the risk of early fatality from radiation exposure of the lungs, bone marrow, and intestines, a relative biological effectiveness (RBE) value is applied. For calculating the effects of alpha radiation on early fatality involving lung tissue, an RBE value of 10 is applied to the $D_{50}$ values derived for gamma and beta radiation. Neither experimental animal nor human data obtained following exposure to plutonium or transuranic elements have indicated a significant case of radiation leukemogenesis, and ingestion of alpha-emitting radionuclides is not considered a hazard to the intestinal tract because the range of the alpha particles is insufficient to penetrate the mucus and intestinal contents and reach the crypt cells. Therefore, for early fatalities involving bone marrow and the gastrointestinal tract, an RBE value of 1 is assumed.

The total lethal risk from all acute effects considered is calculated by summing the cumulative hazards for each lethal mode of injury - that is, the hematopoietic syndrome (bone marrow), the gastrointestinal syndrome (intestines), and the pulmonary syndrome (lungs). The estimated lethality risk from these three competing injuries can be calculated as follows:

$$
\text { Risk }=1-\exp \left\{-\left[\mathrm{H}_{\mathrm{A}} \text { (bone) }+\mathrm{H}_{\mathrm{A}} \text { (lung) }+\mathrm{H}_{\mathrm{A}}(\mathrm{GI})\right]\right\}
$$

The following input options are used for the early effects model in RISKIND: minimal or supportive for level of medical treatment; and lower, central, or upper bound estimate for level of assessment associated with model uncertainties. The parameters used in the early effects model are all taken from the NRC report Health Effects Model for Nuclear Power Plant Accident Consequence Analysis (Abrahamson et al. 1989).

\subsection{LATENT EFFECTS}

Latent effects may result from cumulative exposures, including the short-term and long-term exposures discussed in Sections 2.2.2.3 and 2.2.2.4. The latent health effects considered in RISKIND include the probability of death from cancer and the genetic effects manifested in the exposed individual's offspring.

In addressing the latent effects of human exposure to low-dose radiation, the National Research Council's Committee on the Biological Effects of Ionizing Radiation (BEIR) has prepared a series of reports. The two most recent of the series, BEIR IV and BEIR V. 
were published in 1988 and 1990, respectively (National Research Council 1988, 1990). The $B E I R I V$ report addresses potential health effects of exposure to internally deposited alphaemitting radionuclides. Studies on latent health effects from exposure to low-level, low linear energy transfer (LET) radiation are included in BEIR $V$. These effects include the induction of cancer, genetically determined ill health, developmental abnormalities, and some degenerative diseases.

The BEIR $V$ report estimates an average of about 800 excess cancer mortalities for a 10-rem exposure for 100,000 exposed persons and about 100 to 200 genetic effects per generation for every million person-rem of the total population dose. These findings translate to a total risk coefficient of $8 \times 10^{-4}$ fatal cancers per rem and less than $2 \times 10^{-4}$ genetic effects per rem of exposure per generation. The BEIR $I V$ report includes some cancer risk estimates from internal exposure to several alpha-emitting radionuclides that occur naturally, such as radium and uranium, and some that are artificially produced, such as plutonium isotopes. The estimated cancer risks are generally lower than those of BEIR $V$ if a quality factor of 20 (i.e., currently used in the RISKIND code) is applied to convert rad to rem for alpha radiation.

In developing the cancer fatality estimate, the BEIR V committee did not apply a dose-rate effectiveness factor (DREF) to the solid tumor fraction of the total cancer risk to account for a decreased effectiveness in low-dose exposure situations, such as biological repair that can occur at low dose rates and mitigate radiation damage. However, a DREF of approximately 2 was implicit in the BEIR $V$ model used to predict leukemia risks. Modification of the solid tumor risk fraction by a DRFF of 2 reduces the $8 \times 10^{-4}$ fatal cancers per rem risk coefficient to a value ranging from $4 \times 10^{-4}$ to $5 \times 10^{-4}$ fatal cancers per rem.

The genetic effect risk estimates presented in BEIR $V$ are about $1 \times 10^{-4}$ to $2 \times 10^{-4}$ genetic effects per rem of exposure per generation. The most recent ICRP (1991) estimates of the probability of fatal cancer risk to the public at all ages is about $5 \times 10^{-4}$ cancer fatalities per rem. The probability of genetic effects is $1.3 \times 10^{-4}$ genetic effects per rem. These values are consistent with those of BEIR $V$ and represent the most recent analysis of radiation risk data. In RISKIND, risk coefficients of $8 \times 10^{-4}$ fatal cancers per rem and $2 \times 10^{-4}$ genetic effects per rem are used for a dose greater than or equal to $20 \mathrm{rem}$ 
(Abrahamson et al. 1991). For a dose less than 20 rem, risk coefficients of $5 \times 10^{-4}$ fatal cancers per rem and $1.3 \times 10^{-4}$ genetic effects per rem are used.

A comparison of BEIR $V$ estimates with those of other studies is shown in Table 3.1. These estimates have been recommended by the ICRP (1991), the United Nations Scientific Committee on the Effects of Atomic Radiation (UNSCEAR 1986), and the EPA (1989).

TABLE 3.1 Estimated Lifetime Cancer Mortalities and Genetic Effects

\begin{tabular}{lcc}
\hline \multicolumn{1}{c}{ Source of Estimate } & $\begin{array}{c}\text { Lifetime Cancer } \\
\text { Fatalities per } \\
10^{6} \text { person-rem }\end{array}$ & $\begin{array}{c}\text { Genetic Effects per } \\
\text { Generation per } \\
10^{6} \text { person-rem }\end{array}$ \\
\hline National Research Council (1990) & 790 & $110-200$ \\
UNSCEAR (1986) & $700-1100$ & 119 \\
ICRP (1991) & 500 & 130 \\
EPA (1989) & 390 & 260 \\
\hline
\end{tabular}




\section{REFERENCES}

Abrahamson, S., et al., 1989, Health Effects Model for Nuclear Power Accident Consequence Analysis, Rev. 1, U.S. Nuclear Regulatory Commission Report NUREG/CR-4214.

Abrahamson, S., et al., 1991, Health Effects Model for Nuclear Power Plant Accident Consequence Analysis, Modifications of Models Resulting from Recent Reports on Health Effects of Ionizing Radiation, Rev. 1, Part II, Addendum 1, U.S. Nuclear Regulatory Commission Report NUREG/CR-4214.

Anspaugh, L.R., 1973, Relationship between Resuspended Plutonium in Air and Soil, NVO-140, U.S. Department of Energy, Nevada Operations Office.

Anspaugh, L.R., et al., 1974, Resuspension Element Status Report, The Dynamics of Plutonium in Desert Environments, NVO-142, U.S. Department of Energy, Nevada Operations Office.

Babcock and Wilcox, 1990, BR-100 100-Ton Rail/Barge Spent Fuel Shipping Casks: Preliminary Design Report, February 1990, B\&W Document 51-1177082-02, Lynchburg, Va.

Briggs, G.A., 1969, Plume Rise, U.S. Atomic Energy Commission Critical Review Series, prepared for Nuclear Safety Information Center, Oak Ridge National Laboratory, reprinted by the National Technical Information Service, Springfield, Va.

Briggs, G.A., 1974, Diffusion Estimation for Small Emissions, Environmental Research Laboratories Atmospheric Turbulence and Diffusion Laboratory 1973 Annual Report, Report No. ATDL-106, National Oceanic and Atmospheric Administration.

Chen, S.Y., and Y.C. Yuan, 1988, Calculation of Radiation Dose Rates from a Spent Nuclear Fuel Shipping Cask, Transactions of American Nuclear Society, 56:110-112.

Chen S.Y., et al., 1992, Argonne National Laboratory, unpublished information, Dec.

Eimutis, E.C., and M.G. Konicek, 1972, Derivation of Continuous Functions for the Lateral and Vertical Dispersion Coefficients, Atmospheric Environment, 6:859-863.

General Atomics, 1990, GA-4/GA.9 Legal Weight Truck from Reactor Shipping Casks: Preliminary Design Report, April 1990, GA-A19862, San Diego, Calif.

Holzworth, G., 1972, Mixing Heights, Wind Speeds, and Potential for Urban and Air Pollution throughout the Contiguous United States, AP-101, U.S. Environmental Protection Agency.

International Atomic Energy Agency and Commission of the European Communities, 1992, VAMP, Co-ordinated Research Program on Validation of Environmental Model Prediction: Multiple Pathways Assessment, Vienna, Austria, May. 
International Commission on Radiological Protection, 1966, Deposition and Retention Models for Internal Dosimetry of the Human Respiratory Tract, Health Physics, 12:173.

International Commission on Radiological Protection, 1977, Recommendations of the ICRP, ICRP Publication 26, Pergamon Press, Oxford, United Kingdom.

International Commission on Radiological Protection, 1991, 1990 Recommendations of the International Commission on Radiological Protection, ICRP Publication 60, Pergamon Press, Oxford, United Kingdom.

Lahs, W.R., 1987, Transporting Spent Fuel - Protection Provided Against Severe Highway and Railroad Accident, U.S. Nuclear Regulatory Commission Report NUREG/BR-0111.

Lawrence Livermore National Laboratory, 1987, Shipping Container Response to Severe Highway and Railway Accident Conditions, NUREG/CR-4829, UCID-20733, prepared for U.S. Nuclear Regulatory Commission, Feb.

McMahon, T.A., and P.J. Dennison, 1979, Empirical Atmospheric Deposition Parameters A Survey, Atmospheric Environment, 13:571-585.

National Research Council, 1988, Health Risks of Radon and Other Internally Deposited Alpha-Emitters, BEIR IV, Committee on the Biological Effects of Ionizing Radiation, National Academy Press, Washington, D.C.

National Research Council, 1990, Health Effects of Exposure to Low Levels of Ionizing Radiation, BEIR V Report, Committee on the Biological Effects of Ionizing Radiation, National Academy Press, Washington, D.C.

Neuhauser, K.S., and F.L. Kanipe, 1992, RADTRAN 4: Volume 3, User Guide, Sandia National Laboratories Report SAND89-2370.

Pasquill, F., 1974, Atmospheric Diffusion, 2nd ed., John Wiley \& Sons, New York.

Petersen, W.B., and L.G. Laudas, 1986, INPUFF 2.0A - Multiple Source Gaussian Puff Dispersion Algorithm User's Guide, U.S. Environmental Protection Agency Report EPA/600/8-86/024.

Powell, D.C., et al., 1979, MESODIF-II: A Variable Trajectory Plume Segment Model to Assess Ground-Level Air Concentrations and Deposition of Effluent Releases from Nuclear Power Facilities, U.S. Nuclear Regulatory Commission Report NUREG/CR-0523.

Ritchie, L.T., et al., 1978, Effects of Rainstorms and Runoff on Consequences of Atmospheric Releases from Nuclear Reactor Accidents, Nuclear Safety, 19:220-238.

Ross, D.G., et al., 1985, CITPUFF: A Gaussian Puff Model for Estimating Pollutant Concentration in Complex Terrain, U.S. Department of Agriculture, Rocky Mountain Forest and Range Experimentation Station, RM-261, July. 
Sandoval, R.P., et al., 1991, Estimate of CRUD Contribution to Shipping Cask Containment Requirements, Sandia National Laboratories Report SAND-88-1358, Jan.

Sandquist, G.M., et a)., 1985, Exposures and Health Effects from Spent Fuel Transportation, Rogers and Associates Engineering Corporation, Salt Lake City, Utah.

Sehmel, G.A., 1980, Particles and Gas Dry Deposition: A Review, Atmospheric Environment, 14:983-1011.

Slade, D.H., ed., 1968, Meteorology and Atomic Energy 1968, U.S. Atomic Energy Commission, Washington, D.C.

Stammer, R.E., et al., 1990, Model Study Transportation Accident Characterization, Vanderbilt University, Nashville, Tenn.

United Nation's Scientific Committee on the Effects of Ionizing Radiation, 1986, Ionizing Radiation: Sources and Biological Effects, Report A/41/16, Forty First Session, Supplement No. 16, United Nations, New York.

U.S. Department of Energy, 1986a, Environmental Assessment, Deaf Smith Site, Texas, DOE/RW-0069, Vols. 1-3, Office of Civilian Radioactive Waste Management, May.

U.S. Department of Energy, 1986b, Environmental Assessment, Reference Repository Location, Hanford Site, Washington, DOE/RW-0070, Vols. 1-3, Office of Civilian Radioactive Waste Management, May.

U.S. Department of Energy, 1986c, Environmental Assessment, Yucca Mountain Site, Nevada Research and Development Area, Nevada, DOE/RW-0071, Vols. 1-3, Office of Civilian Radioactive Waste Management, May.

U.S. Department of Energy, 1987a, Analysis of Radiation Doses from Operation of Postulated Commercial Spent Fuel Transportation Systems, DOE-CH/TPO-001.

U.S. Department of Energy, 1987b, Characteristics of Spent Fuel, High-Level Waste, and Other Radioactive Wastes Which May Require Long-Term Isolation, DOE/RW-0184, ORNL/TM-10213, prepared by Oak Ridse National Laboratory, Oak Ridge, Tenn., for U.S. Department of Energy Office of Civilian Radioactive Waste Management.

U.S. Department of Energy, 1988, External Dose-Rate Conversion Factors for Calcuiation of Dose to the Public, DOE/EH-0070, prepared by Oak Ridge National Laboratory, Oak Ridge, Tenn.

U.S. Depurtment of Energy, 1992, Characteristics of Potential Repository Wastes, DOE/RW184-R1, prepared by Oak Ridge National Laboratory, Oak Ridge, Tænn., for U.S. Department of Energy, Office of Civilian Riadioactive Waste Management. 
U.S. Environmental Protection Agency, 1988, Limiting Values of Radionuclide Intake and Air Concentration and Dose Conversion Factors for Inhalation, Submersion, and Ingestion, EPA-520/1-88-020.

U.S. Environmental Protection Agency, 1989, Risk Assessment Methodology, Environmental Impact Statement for Proposed NESHAPS for Radionuclides, Vol. 1, EPA/520/1-89-005.

U.S. Environmental Protection Agency, 1991, Manual of Protective Action Guides and Protective Actions for Nuclear Incidents, EPA 520/1-75-001-A.

U.S. Nuclear Regulatory Commission, 1974, Liquid Metal Fast Breeder Reactor Program, Vol. II, Wash-1535.

U.S. Nuclear Regulatory Commission, 1977a, Calculation of Annual Dose to Man from Routine Releases of Reactor Effluents for the Purpose of Evaluating Compliance with 10 CFR Part 50, Appendix I, Rev. 1, Regulatory Guide 1.109.

U.S. Nuclear Regulatory Commission, 1977b, Final Environmental Statement on the Transportation of Radioactive Material by Air and Other Modes, NUREG-0170.

U.S. Nuclear Regulatory Commission, 1989, Health Effects Model for Nuclear Power Plant Accident Consequence Analysis, NUREG/CR-4214, prepared by Harvard School of Public Health.

Volchok, H.L., 1986, Resuspension of Plutonium-239 in the Vicinity of Rocky Flats, Proc. of Environmental Plutonium Symposium, Los Alamos Scientific Laboratory Report LA-4756, pp. 99-103.

Yuan, Y.C., and D. W/acFarlane, 1992, Al-RISK: A Computer Program for Calculating Doses and Health Risks from Accidental Release of Radioactive Materials, Los Alamos National Laboratory Report LA-UR-92-2636, N-6-92-R123. 
APPENDIX A:

DESCRIPTION OF RADIONUCLIDE INVENTORY DATABASE FOR SPENT NUCLEAR FUELS 


\section{APPENDIX A: \\ DESCRIPTION OF RADIONUCLIDE INVENTORY DATABASE FOR SPENT NUCLEAR FUELS}

A radionuclide inventory database specific to spent nuclear fuels was derived from the computerized databases developed by Oak Ridge National Laboratory (ORNL) (Notz et al. 1987)." These databases were developed for the U.S. Department of Energy (DOE), Office of Civilian Radioactive Waste Management (OCRWM), to establish reference characteristics of radioactive waste materials that may be accepted by DOE for emplacement in the mined geologic disposal system developed under the Nuclear Waste Policy Act of 1982.

The inventory data applicable to spent fuels have been generated by the ORIGEN2 computer code (Croff 1980) and are contained in the Light-Water Reactor (LWR) Quantities Database of ORNL (Notz et al. 1987). Specifically, the radioactivity, given in curies per metric ton of initial heavy metal (Ci/MTIHM), is provided for a detailed list of radionuclides for significant activation- and fission-product nuclides as well as actinides. The inventory data are compiled according to reactor type, fuel burnup, and fuel conling period. Two reference LWRs were used, a pressurized-water reactor (PWR) (Westinghouse) and a boilingwater reactor (BWR) (General Electric). The data are listed for several burnups in megawattdays per MTIHM (MWd/MTIHM): 5,000-MWd/MTIHM increments to 60,000 MWd/MTIHM for the PWR and 40,000 MWd/MTIHM for the BWR. The cooling periods range from 1 to 1 million years.

For application to the RISKIND code described in the main body of this report, a somewhat condensed inventory database was compiled from the ORNL database. This condensed database contains inventory information for all isotcpes contributing more than $0.01 \%$ to the total inventory data. The burnup levels were condensed at 20,000, 25,000, 30,000, 33,000, 35,000, 40,000, and 60,000 MWd/MTIHM for the PWRs, and at 5,000, 20,000, 25,000, 27,500, 30,000, 35,000, and 40,000 MWdMTIHM for the BWRs. The cooling periods selected were $1,5,10,20,30,50,100,1,000$, and 10,000 years. A sample of such inventory data is given in Table A.1.

* The database was recently revised (DOE 1992). This revised database will be incorporated into RISKIND in the next revision. 


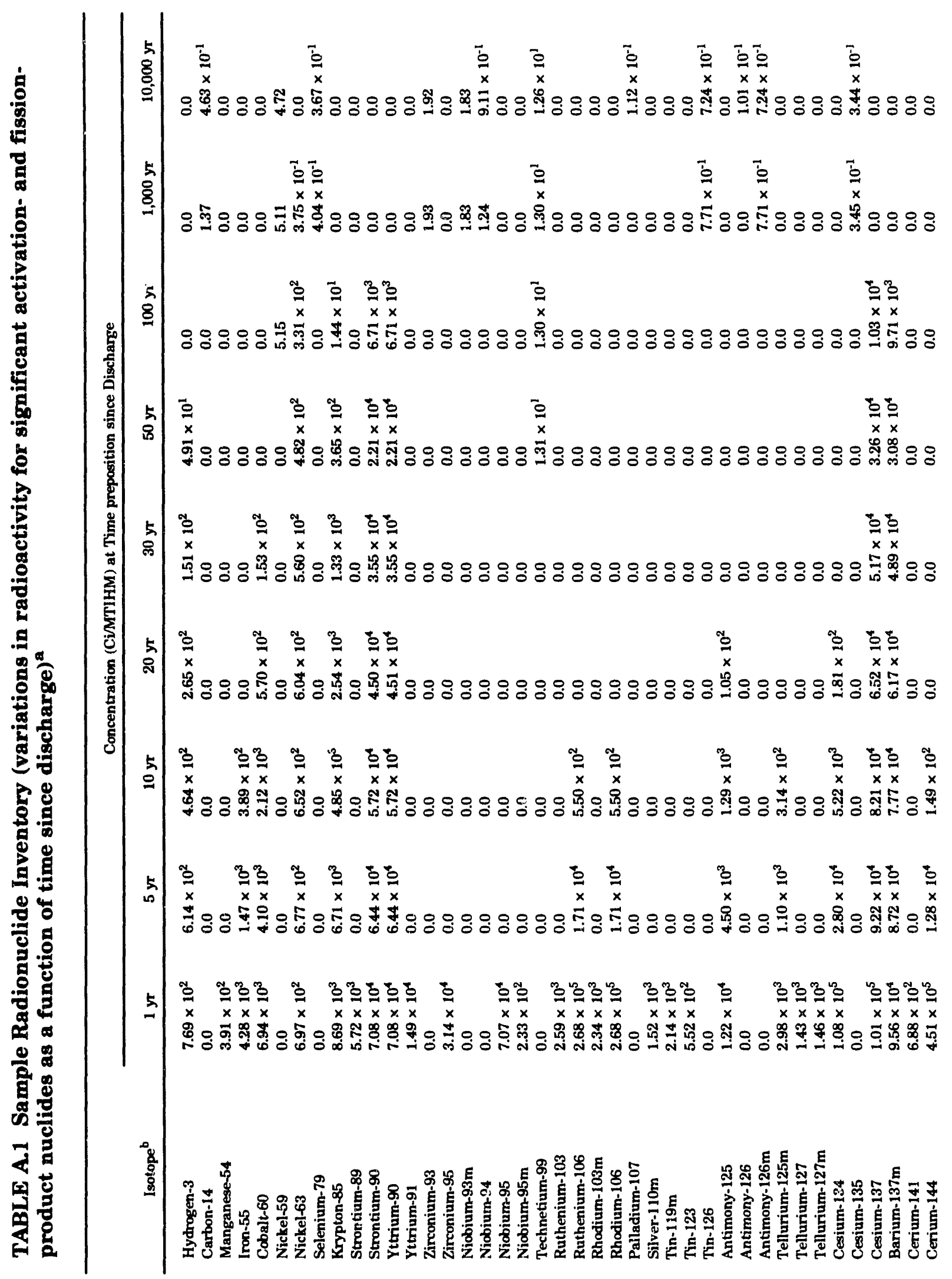




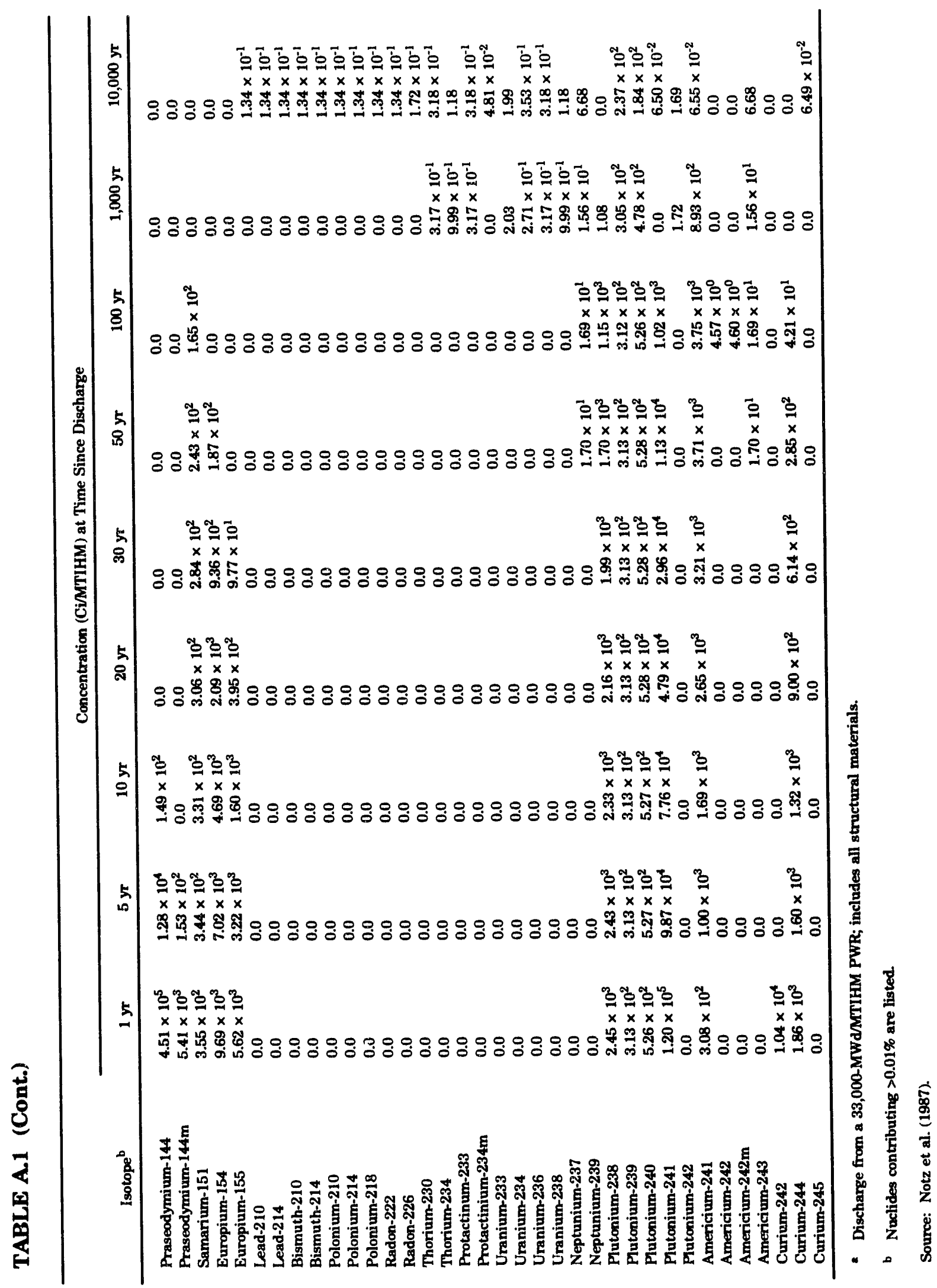




\section{APPENDIX A REFERENCES}

Croff, A.G., 1980, ORIGEN2 - Isotope Generation and Depletion Code - Matrix Exponential Method, User's Manual, ORNL/TM-7175, Oak Ridge National Laboratory, Oak Ridge, Tenn.

Notz, K.J., et al., 1987, Characteristics of Potential Repository Wastes, Vols. 1-6, DOE/RW-0184, prepared by Oak Ridge National Laboratory, Oak Ridge, Tenn., for U.S. Department of Energy, Office of Civilian Radioactive Waste Management.

U.S. Department of Energy, 1992, Characteristics of Potential Repository Wastes, DOE/RW-184-R1, prepared by Oak Ridge National Laboratory, Oak Ridge, Tenn., for the Office of Civilian Radioactive Waste Management. 


\section{APPENDIX B:}

METHOD FOR ADJUSTING CASK EXTERNAL DOSE RATES RELATIVE TO CASK DIMENSIONS 


\section{APPENDIX B:}

\section{METHOD FOR ADJUSTING CASK EXTERNAL DOSE RATES RELATIVE TO CASK DIMENSIONS}

This appendix describes a method developed for adjusting the cask external dose rates when different cask dimensions are used in place of a reference cask.

\section{B.1 FORMULATION}

In this method, the radiation source from the cask is approximated by a uniform surface-source cylinder characterized by a radius $R$ and length $L$ and a surface source strength $S_{a}$, as shown in Figure B.1. For a receptor $P$ located at a distance $r$ from the centerline of the cask (Figure B.1), the radiation (neutron or gamma) flux $\phi$ at the receptor can be calculated by (Jaeger 1968)

$$
\phi(r)=\frac{S_{a} R}{(R+r)} F(\psi, k)
$$

where:

$$
\begin{aligned}
& \psi=\tan ^{-1}\left(\frac{\mathrm{L} / 2}{\mathrm{r}-\mathrm{R}}\right), \\
& \mathbf{k}=\frac{2(\mathrm{rR})^{1 / 2}}{(\mathrm{r}+\mathrm{R})} \text {, and } \\
& \mathrm{F}(\psi, \mathrm{k})=\int_{0}^{\psi} \exp (-\mathrm{k} \sec \theta) \mathrm{d} \theta .
\end{aligned}
$$

where $\psi$ is the angle subtended by the centerline and the edge of the cask, as viewed by the receptor (Figure B.1); L equals the length of the cask; $R$ equals the radius of the cask; and $r$ equals the distance of the receptor measured from the center of the cask. 


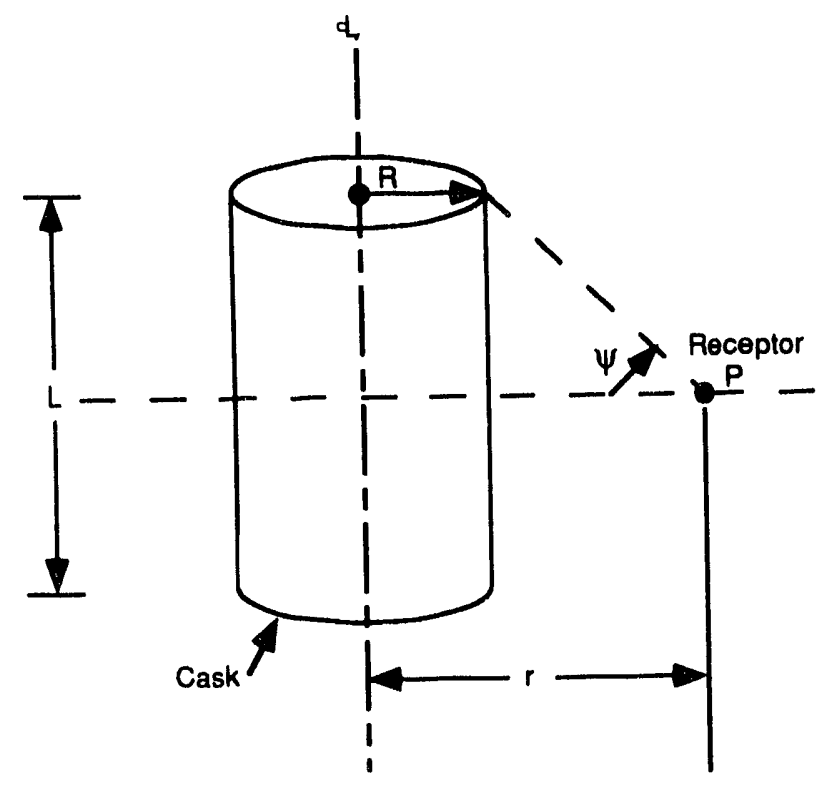

$$
\begin{aligned}
& P=\text { receptor } \\
& \mathrm{R}=\text { cask radius } \\
& L=\text { cask length } \\
& r=\text { distance from } \\
& \text { receptor to the } \\
& \text { cask centerline } \\
& \psi=\tan ^{-1}\left(\frac{L / 2}{r-R}\right)
\end{aligned}
$$

FIGURE B.1 Schematic Diagram Correlating Doses to Cask Dimensions

\section{B.2 DOSE RATE CONVERSION}

In the above calculations, it is assumed that the dose rate is directly proportional to the flux at the receptor. If $K_{0}$ is the flux-to-dose-rate conversion factor, then th dose rate at receptor $P$ is approximated by

$$
\grave{D}(\mathbf{r})=\mathbf{K}_{0} \phi(\mathbf{r})
$$

If $\dot{\mathrm{D}}_{0}(r)$ represents the dose rate at $r$ for the reference cask with dimensions $R_{0}$ and $L_{0}$, and $\dot{D}_{1}(r)$ represents the dose rate at $r$ for a new cask with dimensions $R_{1}$ and $L_{1}$, the adjusted dose rate will be $\dot{\mathrm{D}}_{1}$ because of the dimension changes. Both casks must meet the regulatory dose rate limit for Type $B$ containers (i.e., $10 \mathrm{mrem} / \mathrm{h}$ at $2 \mathrm{~m}$ from the surface); 
therefore, the dose rates at such distances for both casks are assumed to be equal to this limit. From Equation B.1, the following equations can be derived:

$$
\begin{aligned}
& \dot{\mathrm{D}}_{0}\left(\mathrm{R}_{0}+2\right)=\frac{\mathrm{S}_{\mathrm{a} 0} \mathrm{R}_{0} \mathrm{~K}_{0}}{\left(2 \mathrm{R}_{0}+2\right)} \mathrm{F}\left(\psi_{02}, \mathrm{k}_{02}\right) \\
& \dot{\mathrm{D}}_{1}\left(\mathrm{R}_{1}+2\right)=\frac{\mathrm{S}_{\mathrm{a} 1} \mathrm{R}_{1} \mathrm{~K}_{0}}{\left(2 \mathrm{R}_{1}+2\right)} \mathrm{F}\left(\psi_{12}, \mathrm{k}_{12}\right)
\end{aligned}
$$

where:

$$
\begin{aligned}
& \Psi_{02}=\tan ^{-1} \mathrm{~L}_{0} / 4, \\
& \Psi_{12}=\tan ^{-1} \mathrm{~L}_{0} / 4, \\
& \mathrm{k}_{02}=\frac{2\left[\left(\mathrm{R}_{0}+2\right) \mathrm{R}_{0}\right]^{1 / 2}}{\left(2 \mathrm{R}_{0}+2\right)}, \text { and } \\
& \mathbf{k}_{12}=\frac{2\left[\left(\mathrm{R}_{1}+2\right) \mathrm{R}_{1}\right]^{1 / 2}}{\left(2 \mathrm{R}_{1}+2\right)} .
\end{aligned}
$$

where $\psi$ and $k$ are evaluated at $2 \mathrm{~m}$ from the surfaces of the two casks. Both $\dot{\mathrm{D}}_{0}\left(\mathrm{R}_{0}+2\right)$ and $\dot{\mathrm{D}}_{1}\left(\mathrm{R}_{1}+2\right)$ are assumed to be equal at $10 \mathrm{mrem} / \mathrm{h}$.

Thus, the dose rate at a distance $d$ from the surfaces of the two casks is

$$
\begin{aligned}
& \dot{\mathrm{D}}_{0}\left(\mathrm{~d}+\mathrm{R}_{0}\right)=\frac{S_{\mathrm{a} 0} R_{0} \mathrm{~K}_{0}}{\mathrm{~d}+2 R_{0}} F\left(\psi_{0}, \mathrm{k}_{0}\right) \\
& \dot{\mathrm{D}}_{1}\left(\mathrm{~d}+\mathrm{R}_{1}\right)=\frac{S_{\mathrm{a} 1} R_{1} \mathrm{~K}_{0}}{\mathrm{~d}+2 R_{1}} F\left(\psi_{1}, \mathrm{k}_{1}\right)
\end{aligned}
$$

where:

$$
\begin{aligned}
& \psi_{0}=\tan ^{-1}\left(\frac{L_{0} / 2}{d}\right), \\
& \psi_{1}=\tan ^{-1}\left(\frac{L_{1} / 2}{d}\right),
\end{aligned}
$$




$$
\begin{aligned}
& k_{0}=\frac{2\left[\left(R_{0}+d\right) R_{0}\right]^{1 / 2}}{\left(2 R_{0}+d\right)}, \text { and } \\
& k_{1}=\frac{2\left[\left(R_{1}+d\right) R_{1}\right]^{1 / 2}}{\left(2 R_{1}+d\right)}
\end{aligned}
$$

\section{B.3 DOSE RATE ADJUSTMENT}

The surface sources $S_{a 0}$ and $S_{a 1}$ in Equations B.6 and B.7 are determined from the total source, $S_{0}=2 \pi S_{a} R L$. By using the relationship of $S_{a 0}$ and $S_{a 1}$ and Equations $B .12$ and B.13, the ratio $Q(d)$ of the dose rates at a distance $d$ meters from the surfaces of the two casks becomes

$$
\begin{aligned}
Q(d) & =\frac{\dot{D}_{1}\left(d+R_{0}\right)}{\dot{D}_{0}\left(d+R_{1}\right)} \\
& =\frac{\left(2 R_{0}+d\right)}{\left(2 R_{1}+d\right)} \cdot \frac{F\left(\psi_{1}, k_{1}\right)}{F\left(\psi_{0}, k_{0}\right)} \cdot \frac{\left(2 R_{1}+2\right)}{\left(2 R_{0}+2\right)} \cdot \frac{F\left(\psi_{02}, k_{02}\right)}{F\left(\psi_{12}, k_{12}\right)}
\end{aligned}
$$

The ratio $Q(d)$ depends on the reference cask dimensions, $R_{0}$ and $L_{0}$, and the new cask dimensions, $R_{1}$ and $L_{1}$. The ratio $Q(d)$ can be used to adjust the dose rates obtained from Equation 2.1 due to changes in cask dimensions. That is, the adjusted dose rate $\dot{\mathrm{D}}_{1}(\mathrm{~d})$ for a receptor at a distance $d$ meters from the cask surface can be obtained by

$$
\dot{\mathrm{D}}_{1}(\mathrm{~d})=\dot{\mathrm{D}}_{0}(\mathrm{~d}) \mathrm{Q}(\mathrm{d})
$$

where $\dot{D}_{0}(d)$ is the known dose rate for the reference cask, and $Q(d)$ is the dose-rate ratio obtained from Equation B.19.

\section{APPENDIX B REFERENCE}

Jaeger, R.G., ed., 1968, Engineering Compendium on Radiation Shielding, Vol. I, SpringerVerlag, Berlin, West Germany. 
APPENDIX C:

METHOD FOR SCREENING RADIONUCLIDES 


\section{APPENDIX C:}

\section{METHOD FOR SCREENING RADIONUCLIDES}

Spent nuclear fuels are usually irradiated in nuclear reactors for many hundreds of hours before they are removed for refueling. Thus, even after years of cooling, the spent fuels may still contain several hundred different radionuclides. Because it is necessary to limit the number of nuclides for each assessment when using RISKIND (up to 40 nuclides), and because not all of these radionuclides are radiologically significant in the environment, selecting radionuclides of potential importance becomes an essential task. With careful screening, the number of nuclides selected can be reduced to a manageable size without sacrificing accuracy in dose calculations. The process used to select radionuclides for dose calculations is described in this appendix.

\section{C.1 KEY PARAMETERS}

The relative importance of the various radionuclides contained in spent nuclear fuels is evaluated by considering (1) the quantity of each radionuslide present, (2) the fraction of each radionuclide that would be released to the atmosphere during an accident, and (3) the various exposure pathway-dependent factors. The latter includes soil-to-vegetation transfer factors, vegetation-to-meat and -milk transfer factors, and human and animal food ingestion rates; the dose conversion factors for each exposure pathway; and the radionuclide decay constant and weathering removal parameter that determines how long deposited radioactive material remains on the ground. Because this screening process is designed for detailed dose analysis, only key parameters that are important in determining radiological impacts to humans are considered.

The quantity of each radionuclide present in the spent fuel is dependent on characteristics such as fuel burnup, type of reactor (pressurized-water reactor [PWR] or boiling-water reactor [BWR]), and age of fuel (cooling time). Oak Ridge National Laboratory (ORNL) has compiled a spent fuel radionuclide database (Notz et al. 1987) with the ORIGEN2 code (Croff 1980). The results of the ORNL data compilation are given in the U.S. Department of Energy (DOE) report Characteristics of Spent Fuel, High-Level Waste, and 
Other Radioactive Wastes Which May Require Long-Term Isolation (DOE 1987)." In RISKIND, the radionuclide source term in the spent fuel, $Q(i)$, is calculated on the basis of the user's input values for 'uel burnup, type of reactor, and age of fuel.

The amount of a radionuclide that can be released to the atmosphere during an accident is usually represented by the release fraction of the total source inventory in the cask. The release fraction as defined for RISKIND is the fraction of the radioactivity inventory in the cask that could become airborne during an accident. Because the amount of radioactivity that could be released is highly dependent on the severity of the accident, accurate calculation of doses requires that this value be determined for each accident scenario. In the RISKIND code, the screening process is calculated for each of the 20 cask response regions defined in the U.S. Nuclear Regulatory Commission (NRC) modal study (Lawrence Livermore National Laboratory [LLNL] 1987). For convenience, radionuclides are grouped by physical and chemical behavior: particulates; ruthenium, cesium, and iodine isotopes; and noble or inert gases. The release parameters for these five types of radionuclides have been discussed in Section 2.2.1 of this document.

\section{C.2 PATHWAY CONSIDERATIONS}

In RISKIND, three pathways that would lead to human exposure following atmospheric release of radionuclides are used to determine the relative health hazards of one radionuclide versus others in the shipping cask. The first pathway (I) is the short-term exposure from air immersion and inhalation during plume passage; it used to determine the relative importance of nuclides in causing individual doses from the passing plume. The second pathway (II) is the long-term external radiation exposure from contaminated ground; it is used to screen each nuclide's relative importance with respect to the long-term hazard of residing on the contaminated land. The third pathway (III) is the long-term internal radiation exposure from ingestion of contaminated foods; it is used to screen each nuclide relative to the hazard from eating or drinking contaminated food products and water.

* The database was recently revised (DOE 1992). This revised database will be incorporated intc the next revision of RISKIND. 


\section{C.3 SCREENING PARAMETERS}

The dose received from pathway $I$ at a particular location from radionuclide i can be writtein as

$$
\operatorname{DI}(\mathrm{i})=\sum_{\mathrm{j}=1,2} \operatorname{DFI}(\mathrm{i}, \mathrm{j}) \mathrm{Q}(\mathrm{i}) \operatorname{RS}(\mathrm{i}) \overline{\mathrm{C}}_{\mathrm{a}}(\mathrm{i})
$$

where:

$$
\begin{aligned}
& \mathrm{DI}(\mathrm{i}) \text { = dose from pathway } \mathrm{I} \text { (short-term) exposure for radionuclide } \mathrm{i} \text {; } \\
& \operatorname{DFI}(i, j)=\text { appropriate dose conversion factor for radionuclide } i \text {, exposure } \\
& \text { pathway j; } \\
& \mathrm{j}=1 \text {, for inhalation; } \mathrm{j}=2 \text {, for air immersion; } \\
& \mathrm{Q}(\mathrm{i})=\text { source inventory of radionuclide } \mathrm{i} \text {; } \\
& \mathrm{RS}(\mathrm{i})=\text { expected release fraction for a unit for radionuclide } \mathrm{i} \text {; and } \\
& \overline{\mathbf{C}}_{\mathrm{a}}(\mathrm{i})=\text { time-integrated relative air concentration factor at a reference } \\
& \text { location for radionuclide } i ; \bar{C}_{a}(i) \text { is assumed to be independent } \\
& \text { of radionuclide i, i.e., } \overline{\mathrm{C}}_{\mathrm{a}}(\mathrm{i})=\overline{\mathrm{C}}_{\mathrm{a}} \text {. }
\end{aligned}
$$

The relative importance of a radionuclide for pathway I exposure is calculated as

$$
F I(i)=D I(i) \frac{D I(i)}{\sum_{i} \overline{D I}(i)}
$$

Equation C.2 can be written as

$$
F I(i)=\frac{\sum_{j=1,2} Q(i) \operatorname{RS}(i) \operatorname{DFI}(i, j)}{\sum_{i} \sum_{j=1,2} Q(i) \operatorname{RS}(i) \operatorname{DFI}(i, j)}
$$

The dose received from pathway II (long-term external exposure from ground contamination) can be written as

$$
\begin{aligned}
& \operatorname{DII}(i)=\operatorname{DFII}(i) \overline{\mathrm{C}}_{\mathrm{g}}(\mathrm{i}) \\
& \overline{\mathrm{C}}_{\mathrm{g}}(\mathrm{i})=\mathrm{Q}(\mathrm{i}) \operatorname{RS}(\mathrm{i}) \overline{\mathrm{C}}_{\mathrm{a}}(\mathrm{i}) \mathrm{V}_{\mathrm{d}}(\mathrm{i}) \mathrm{TG}(\mathrm{i}) \\
& \mathrm{TG}(\mathrm{i})=\left\{1-\exp \left[-\lambda_{\mathrm{g}}(\mathrm{i}) \mathrm{T}\right]\right\} / \lambda_{\mathrm{g}}(\mathrm{i})
\end{aligned}
$$


where:

$$
\begin{aligned}
\text { DII }(\mathrm{i})= & \text { dose from external exposure to ground contamination for } \\
& \text { radionuclide } \mathrm{i} \\
\mathrm{DFII}(\mathrm{i})= & \text { dose conversion factor for ground external exposure; } \\
\overline{\mathrm{C}}_{\mathrm{g}}(\mathrm{i})= & \text { time-integrated ground concentration for radionuclide } \mathrm{i} ; \\
\mathrm{V}_{\mathrm{d}}(\mathrm{i})= & \text { deposition velocity for radionuclide } \mathrm{i} ; \\
\lambda_{\mathrm{g}}(\mathrm{i})= & \text { effective removal constant, including radioactive decay and } \\
& \text { weathering, for radionuclide } \mathrm{i} \text {; and } \\
\mathrm{T}= & \text { total time period for ground external exposure (default: } 50 \mathrm{yr}) .
\end{aligned}
$$

The relative radiation hazard of a radionuclide from pathway II exposure is calculated as

$$
F I I(i)=\frac{D I i(i)}{\sum_{i} \operatorname{DII}(i)}
$$

Explicitly,

$$
F I I(i)=\frac{Q(i) R S(i) V_{d}(i) \operatorname{DFII}(i) T G(i)}{\sum_{i} Q(i) R S(i) V_{d}(i) \operatorname{DFII}(i) T G(i)}
$$

Pathway III accounts for long-term food ingestion. The amount of radioactivity ingested over time through the food pathway is difficult to assess. A simplified approach is used for screening purposes. The dose received from ingestion of food is approximated by estimating radionuclides in foodstuff via root uptake mechanisms from soil. The dose received from pathway III is approximated by

$$
\begin{aligned}
& \text { DIII(i) }=\text { DFIII(i) } S_{v}(i)[F 1(i)+F 2(i)+F 3(i)] \bar{C}_{g}(i) \\
& F 1(i)=F_{b}(i) Q_{a} U_{b} / \rho \\
& F 2(i)=F_{m}(i) Q_{a} U_{m} / \rho \\
& F 3(i)=0.5 U_{v} / \rho
\end{aligned}
$$


where:

$$
\begin{aligned}
\operatorname{DIII}(i)= & \text { ingestion dose factor for pathway III exposure; } \\
\operatorname{DFIII}(i)= & \text { ingestion dose conversion factor for radionuclide } i ; \\
S_{v}(i)= & \text { soil-to-vegetation transfer factor for radionuclide } i ; \\
F_{b}(i)= & \text { meat transfer factor for radionuclide } i ; \\
F_{m}(i)= & \text { milk transfer factor for radionuclide } i ; \\
U_{b}, U_{m}, U_{v}= & \text { human food ingestion rate for meat, milk, and vegetables, } \\
& \text { respectively; } \\
Q_{a}= & \text { animal pasture ingestion rate for meat cattle and milk cows; } \\
& \text { and } \\
\rho= & \text { vegetation yield density of pastureland or a vegetable garden. }
\end{aligned}
$$

The relative importance of radionuclide i for pathway III exposure can be expressed by

$$
\operatorname{FIII}(i)=\frac{\operatorname{DIII}(\mathrm{i})}{\sum_{\mathrm{i}} \overline{\mathrm{DIII}(\mathrm{i})}}
$$

Explicitly,

$$
F I I(i)=\frac{\text { DFIII(i) Q(i) RS(i) } V_{d}(i) S_{v}(i)[F 1(i)+F 2(i)+F 3(i)] T G(i)}{\sum_{i} \operatorname{DFIII}(i) Q(i) \overline{F S}(i) V_{d}(i) S_{v}(i)[F 1(i)+F 2(i)+F 3(i)] T G(i)}
$$

The radionuclide selection criterion in RISKIND is based on the calculated relative importance of the values of FI(i), FII(i), and FIII(i). The screening procedure is such that radionuclides are selected as

FI(i) $>$ S, or FII(i) $>$ S, or FIII(i) $>$ S

where $\mathrm{S}$ is the radionuclide selection criterion (default: 0.01 , or 99\%). In using RISKIND, the radionuclide selection process follows the procedures described above until the total number of selected nuclides exceeds the prescribed limit of 40 . If the number of nuclides selected exceeds this limit, it is recommended that the user change the input value of $S$ to 
a larger value so that the dose calculation will cover the whole range of nuclides in the spent fuels.

In RISKIND, up to 40 radionuclides can be selected for each accident scenario. By selecting an appropriate $S$ value, the number of radionuclides considered can be reduced from about 100 to a much smaller number while maintaining a high degree of accuracy in the calculated results.

\section{APPENDIX C REFERENCES}

Croff, A.G., 1980, ORIGEN2 - Isotope Generation and Depletion Code - Matrix Exponential Method, User's Manual, ORNL/TM-7175, Oak Ridge National Laboratory, Oak Ridge, Tenn.

Lawrence Livermore National Laboratory, 1987, Shipping Container Response to Severe Highway and Railway Accident Conditions, NUREG/CR-4829, UCID-20733, prepared for U.S. Nuclear Regulatory Commission, Feb.

Notz, K.J., et al., 1987, Characteristics of Potential Repository Wastes, Vols. 1-6, DOE/RW-0184, prepared by Oak Ridge National Laboratory, Oak Ridge, Tenn., for U.S. Department of Energy, Office of Civilian Radioactive Waste Management.

U.S. Department of Energy, 1987, Characteristics of Spent Fuel, High-Level Waste, and Other Radioactive Wastes Which May Require Long-Term Isolation, DOE/RW-0184, ORNL TM-10213, prepared by Oak Ridge National Laboratory, Oak Ridge, Tenn., for U.S. Department of Energy, Office of Civilian Radioactive Waste Management.

U.S. Department of Energy, 1992, Characteristics of Potential Repository Wastes, DOE/RW-184-R1, prepared by Oak Ridge National Laboratory, Oak Ridge, Tenn., for U.S. Department of Energy, Office of Civilian Radioactive Waste Management. 
APPENDDX D:

METHOD FOR ESTIMATING THE SPALLATION OF CRUD MATERIAL 


\section{APPENDIX D:}

\section{METHOD FOR ESTIMATING THE SPALLATION OF CRUD MATERIAL}

\section{D.1 SOURCES OF CRUD}

A loaded spent fuel shipping cask has three sources of radioactivity: (1) the radionuclides contained within the individual fuel rods that make up the fuel assemblies, (2) the residual activity on the cask cavity surfaces as a result of loading operations and previous shipments, and (3) fission- and activation-product activity associated with deposited material (i.e., crud) on the fuel assembly surfaces. This appendix describes the method used to estimate the amount of crad material that could be spalled from a shipping cask during a transportation accident. The method follows the information and methodology described in a recent Sandia National Laboratories report by Sandoval et al. (1991). Because of the sparsity of experimental data in the area of spallation fractions for mechanical loads and the lack of information on particle size distributions of spalled crud deposits on spent fuel, the results presented in Sandoval et al. (1991) are of limited use and are upper bound estimates. Further experimental and analytical analyses would be necessary if a more accurate prediction of crud release were required.

\section{D.2 CHARACTERISTICS OF CRUD}

Crud is a mixture of reactor primary cooling system corrosion products that have deposited on fuel rod surfaces. These deposits contain neutron-activated nuclides and may also contain fissile particles and fission products. During shipment, crud may spall from the rods, become airborme in the cask cavity, and be released to the environment should a leak path develop in the cask containment system. The release rate is dependent on the properties of the crud in terms of its specific activity, radioactive species, amount of crud available for release, spallation properties, and particle size distribution.

The crud activity inventory, as discussed in Sandoval et al. (1991), is a function of fuel type, fuel age, isotope composition, and reactor system chemistry. The crud spallation rate and initial particle size distribution of dispersed crud are functions of transport and accident conditions, fuel type, and fuel history. The leakage rate is dependent on cask design 
in terms of cask cavity dimensions and configuration, number and type ur fuel assemblies in the cask, surface area of the cask cavity, basket, fuel rods, and so forth.

The maximum amount of crud-borne activity that could be released to the environment because of a breach in the integrity of the shipping cask is the total crud inventory in the cask. A number of attenuation mechanisms can significantly mitigate this source term. These include the processes that render the crud particles airborne, deposition and gravitational settling of the particulates during transport from their point of origin to the breach point in the shipping package, the mode and duration of the driving force that affects such transport, and the possibility that spalled crud particles could plug the leak path. In RISKIND, all of the spalled crud material is conservatively assumed to be released to the environment for all U.S. Nuclear Regulatory Commission (NRC) modal study response regions (Lawrence Livermore National Laboratory [LLNL] 1987) except region $R(1,1)$, for which no release is assumed because no leak pat'l has been identified (see Section 2.2.1).

\section{D.3 CRUD INVENTORY}

Sufficient data are not available to completely specify the crud characteristics for each type of fuel and other variables. Therefore, the conservatively estimated average and maximum surface activity densities measured on the fuel rods and tabulated in Sandoval et al. (1991) are used by RISKIND for estimating the total crud inventory in a cask. The densities used by RISKIND for crud release analysis are given in Table D.1 for both pressurized-water reactor (PWR) and boiling-water reactor (BWR) fuel assemblies. In

TABLE D.1 Crud Surface Activity Density at Time of Fuel Discharge

\begin{tabular}{|c|c|c|c|}
\hline \multirow{2}{*}{$\begin{array}{l}\text { Fuel } \\
\text { Type }\end{array}$} & \multicolumn{3}{|c|}{ Density $\left(\mu \mathrm{Ci} / \mathrm{cm}^{2}\right)$} \\
\hline & Average & Maximum & Range \\
\hline $\begin{array}{l}\text { PWR } \\
\text { BWR }\end{array}$ & $\begin{array}{r}4 \\
350\end{array}$ & $\begin{array}{r}140 \\
1,250\end{array}$ & $\begin{array}{c}0.1-140 \\
97-1,250\end{array}$ \\
\hline
\end{tabular}

Source: Sandoval et al. (1991). 
calculating the actual crud surface density at the time of accident, these tabulated values are adjusted by the decay of cobalt-60, according to the age of the fuel ir the cask. This adjustment is made because cobalt-60 accounts for $99 \%$ of the activity at 8 years from fuel discharge for PWR fuel and 98\% of the activity at 5 years from fuel discharge for BWR fuel. The other crud isotopes - such as cobalt-58, manganese-54., chromium-51, iron-59, zirconium-95, antimony-125, and zinc-65 - can be ignored.

The total crud inventory inside a cask is the product of the crud surface density and the total surface area of the fuel rod. The total surface area of the fuel rod inside a cask is a function of the sask design, the number of fuel assemblies, and the type of fuel. The surface areas of a cask cavity, including the number of fuel rods for currently used shipping casks, have been estimated and are presented in Sandoval et al. (1991). Table D.2 presents the geometric parameters and fuel assembly information for currently used cask types. The geometric parameters of the new types of casks should be reevaluated when new cask data become available.

\section{D.4 CRUD SPALLATION}

Crud spallation depends on the condition of the crud at the time of fuel discharge, the effects of pool storage, and subsequent hardling. The ability of crud to become airborne depends on the particle size distribution of the spalled crud. Some crud (i.e., flocculent crud, usually on BWR fuel rods) can be easily removed from the fuel rod with a soft brush, whereas tenacious crud, such as that usually found on PWR fuel rods, is not easily removed. Because of insufficient data on crud particle spallation due to impact or shock-related force on the cask during transport, spallation fractions of 1.0 were conservatively assumed by Sandoval et al. (1991) for all impact-related releases. In RISKIND, a spallation fraction of 1.0 is assumed for all levels of mechanical loads above $0.2 \%$ strain. A spallation fraction of 0.15 was estimated as the upper bound for crud particle spallation fractions for the regulatory fire accident condition ( 30 -minute exposure to a fire of approximately $1,500^{\circ} \mathrm{F}$ ). This value is assumed for all levels of thermal loads above a $500^{\circ} \mathrm{F}$ lead midlayer thickness temperature. The values of the spallation fraction assumed for the 20 cask accicint response regions are given in Table D.2. 
TABLE D.2 Current Cask and Fuel Assembly Design Parameters ${ }^{\text {a }}$

\begin{tabular}{llccc}
\hline \multicolumn{1}{c}{ Cask Type } & $\begin{array}{l}\text { Fuel } \\
\text { Type }\end{array}$ & $\begin{array}{c}\mathrm{V} \\
\left(\mathrm{m}^{3}\right)\end{array}$ & $\begin{array}{l}\mathrm{A}_{\mathrm{t}} \\
\left(\mathrm{m}^{2}\right)\end{array}$ & $\mathrm{N}_{\mathrm{a}}$ \\
\hline NLI-1/2 & PWR & 0.155 & 39.0 & 1 \\
NLI-1/2 & BWR & 0.129 & 26.7 & 2 \\
TN-8 & PWR & 0.151 & 37.0 & 3 \\
TN-9 & BWR & 0.070 & 13.6 & 7 \\
NAC-1/NFS-4 & PWR & 0.257 & 39.5 & 1 \\
NAC-1/NFS-4 & BWR & 0.268 & 27.2 & 2 \\
IF-300 & PWR & 2.32 & 251.6 & 7 \\
IF-300 & BWR & 2.34 & 209.5 & 18 \\
NLI-10/24 & PWR & 3.27 & 357.4 & 10 \\
NLI-10/24 & BWR & 3.27 & 227.6 & 24 \\
\hline
\end{tabular}

a $V=$ void volume of loaded cask; $A_{t}=$ total surface area of cask cavity, including fuel rods; and $\mathrm{N}_{\mathrm{a}}=$ number of assemilies that can be shipped in cask.

b TN-8 has three compartments; TN-9 has seven compartments; values given are per compartment.

Source: Sandoval et al. (1991).

TABLE D.3 Spallation Values for NRC Modal Study Cask Response Regions

\begin{tabular}{cccc}
\hline $\begin{array}{c}\text { Response } \\
\text { Region }\end{array}$ & $\begin{array}{c}\text { Spallation } \\
\text { Fraction }\end{array}$ & $\begin{array}{c}\text { Response } \\
\text { Region }\end{array}$ & $\begin{array}{c}\text { Spallation } \\
\text { Fraction }\end{array}$ \\
\hline 1 & 0.15 & 11 & 1 \\
2 & 1 & 12 & 1 \\
3 & 1 & 13 & 0.15 \\
4 & 1 & 14 & 1 \\
5 & 0.15 & 15 & 1 \\
6 & 1 & 16 & 1 \\
7 & 1 & 17 & 0.15 \\
8 & 1 & 18 & 1 \\
9 & 0.15 & 19 & 1 \\
10 & 1 & 20 & 1 \\
\hline
\end{tabular}




\section{APPENDIX D REFERENCES}

Lawrence Livermore National Laboratory, 1987, Shipping Container Response to Severe Highway and Railway Accident Conditions, NUREG/CR-4829, UCID-20733, prepared for U.S. Nuclear Regulatory Commission, Feb.

Sandoval, R.P., et al., 1991, Estimate of CRUD Contribution to Shipping Cask Containment Requirements, Sandia National Laboratories Report SAND88-1358, Jan. 
APPENDIX E:

METHOD FOR ESTIMATING CASK RESPONSE FROM USER-SPECIFIED ACCIDENT SCENARIOS 


\section{APPENDIX E: \\ METHOD FOR ESTIMATING CASK RESPONSE FROM USER-SPECIFIED ACCIDENT SCENARIOS}

In a shipping accident involving spent nuclear fuel, mechanical or thermal cask response or both can be generated and damage to the cask can occur. The response depends on many factors, which are descrihed in the modal study of the U.S. Nuclear Regulatory Commission (Lawrence Livermore National Laboratory [LLNL] 1987). Such factors include the mechanical loadings generated by the accident impact velocity and the object that is struck and, in the event of a fire, the thermal loadings generated by flame temperature and duration of the fire. This appendix describes the subroutine implemented in RISKIND to determine the magnitude of the cask response on the basis of user-specified accident scenarios. The subroutine incorporates the parameters developed for the reference casks in the modal study. Because the response can be different for various cask designs subjected to the same accident conditions, reevaluation of the cask response may be necessary for a more accurate assessment of the potential radiation hazards when cask designs significantly different from those of the reference casks are involved. In the modal study, an analytical method based on various computer codes was used to estimate cask responses. These computer codes have been benchmarked or validated against experimental data.

Two representative cask designs were developed in the modal study (LLNL 1987): one for truck shipments and the other for rail shipments of spent fuel. The configurations of these representative casks are shown in Figure E.1 for a truck cask and Figure E.2 for a rail cask. The truck cask is designed to allow for transport of a single pressurized-water reactor (PWR) fuel assembly; the rail cask capacity is 21 PWR fuel assemblies. A detailed description of the designs is provided in the modal study (LLNL 1987).

The cask response state during an accident is categorized in terms of the magnitude of the mechanical and thermal loads that could be received by a spent fuel cask. Both loads generate response states for a cask that could result in damage to the cask and the release of radioactive material. Because specific mechanical and thermal loading conditions can affect the cask under a variety of accident conditions, identifying the loading parameters is an essential task. 

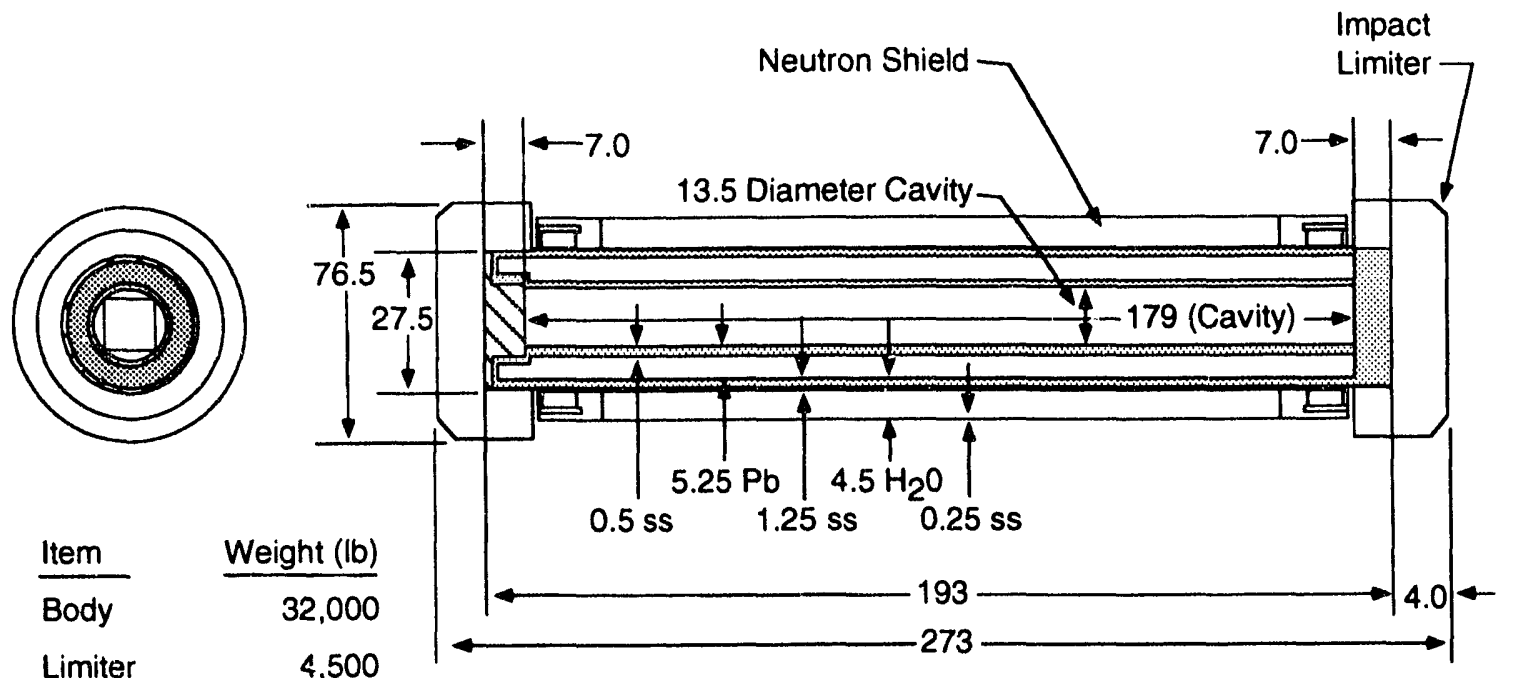

\begin{tabular}{lr} 
Limiter & 4,500 \\
Contents & 2,500 \\
\cline { 2 - 2 } & 39,000
\end{tabular}

All dimensions are in inches.

$$
\begin{aligned}
\mathrm{Pb} & =\text { Lead } \\
\mathrm{H}_{2} \mathrm{O} & =\text { Water } \\
\mathrm{ss} & =\text { Stainless Steel }
\end{aligned}
$$

FIGURE E.1 Representative Truck Cask Design Used for Dynamic Structural and Thermal Response Studies (Source: Modified from LLNL 1987)

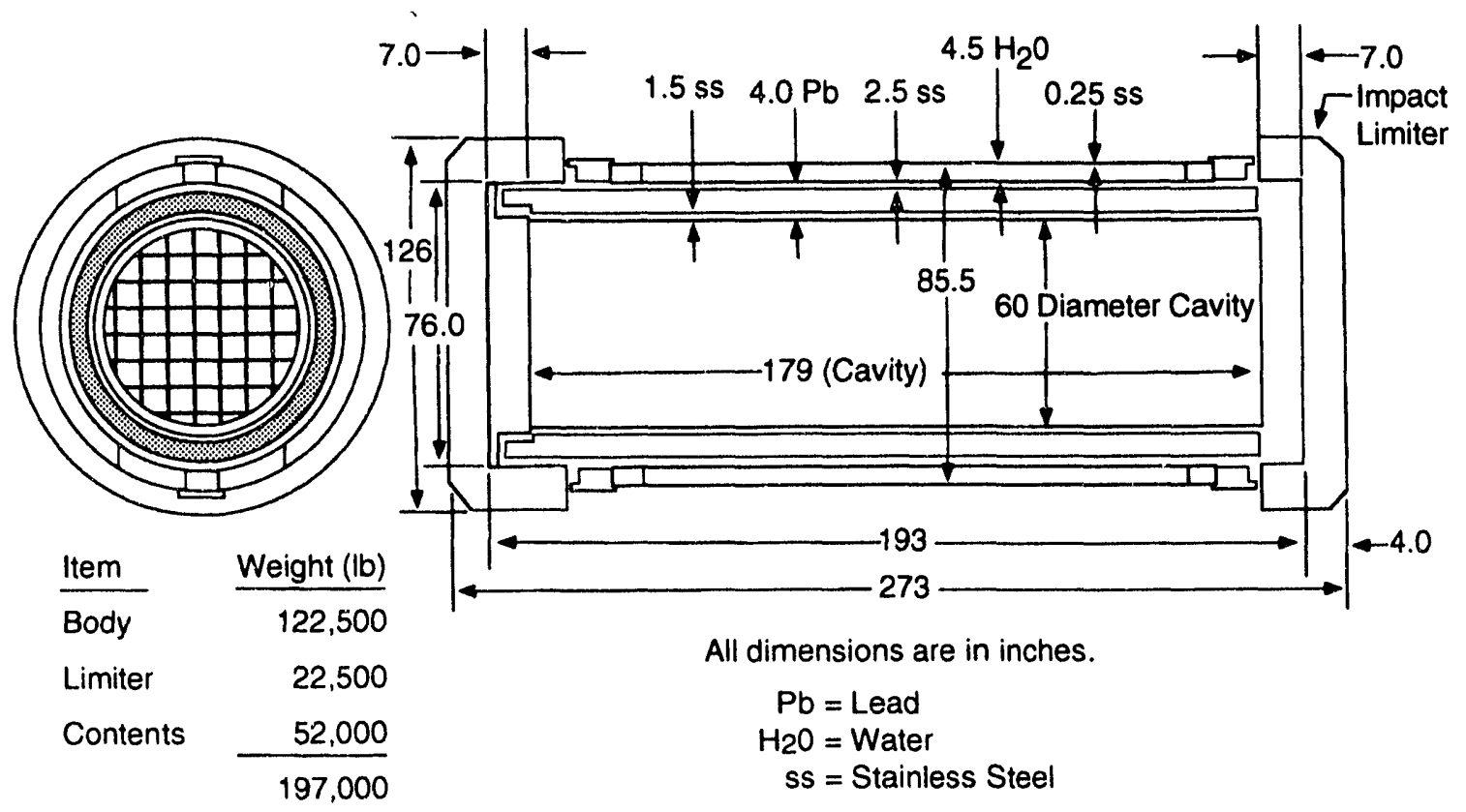

FIGURE E.2 Representative Rail Cask Design Used for Dynamic Structural and Thermal Response Studies (Source: Modified from LLNL 1987) 


\section{E.1 MECHANICAL LOADS}

The dominant mechanical loads have been identified as the forces on the cask caused by impact with a surface or hard object. Three major accident parameters have been identified that affect the cask mechanical response and may cause damage: (1) impact velocity, (2) orientation of the cask, and (3) hardness of the object impacted. The impact velocity depends on the relative velocity of the cask and the angle of impact with respect to the object impacted. The relative velocity is the relative velocity of the cask and the impact object at the time of impact. The impact angle is the angle between the cask velocity and the plane of the surface struck. The impact velocity can be calculated as

Impact Velocity $=$ Cask Velocity $\times \sin \alpha$

The cask orientation angle is the angle between the accident velocity and impact velocity; Figure E.3 shows the interrelationship of these accident parameters. The impact on a surface with a $0^{\circ}$ cask orientation constitutes a sidewise impact, whereas a $90^{\circ}$ cask orientation constitutes an endwise impact. The object hardness is the hardness of the object impacted during the accident. Four increasing levels of object hardness are categorized in the modal study (LLNL 1987): very soft (water), soft (tillable soil), medium (hard soil/soft rock), and unyielding (hard rock).

To characterize mechanical load response states, the strain on the inner shell of the shipping cask was selected as the single parameter in the modal study (LLNL 1987). The relationships between the strain and various accident parameters such as cask velocity, impact angle, cask orientation, and object hardness were investigated extensively. Three discrete levels of maximum strain on the inner shell were used to relate ranges of response states and mechanical loads to potential radiological hazards: $0.2 \%$ (elastic), $2 \%$ (plastic), and $30 \%$ (plastic) strain at the inner shell. The relationship between strain and impact velocity has been developed for various object hardnesses and cask orientations. The impact velocities required to reach the three discrete levels of maximum strain on the inner shell for the representative truck and rail casks are given in Table E.1. By using the bounding impact velocities for various cask orientations and impact surfaces, the response regions for the representative truck and rail casks can be determined by interpolation for any combination of impact velocity, cask orientation, and impact hardness. 

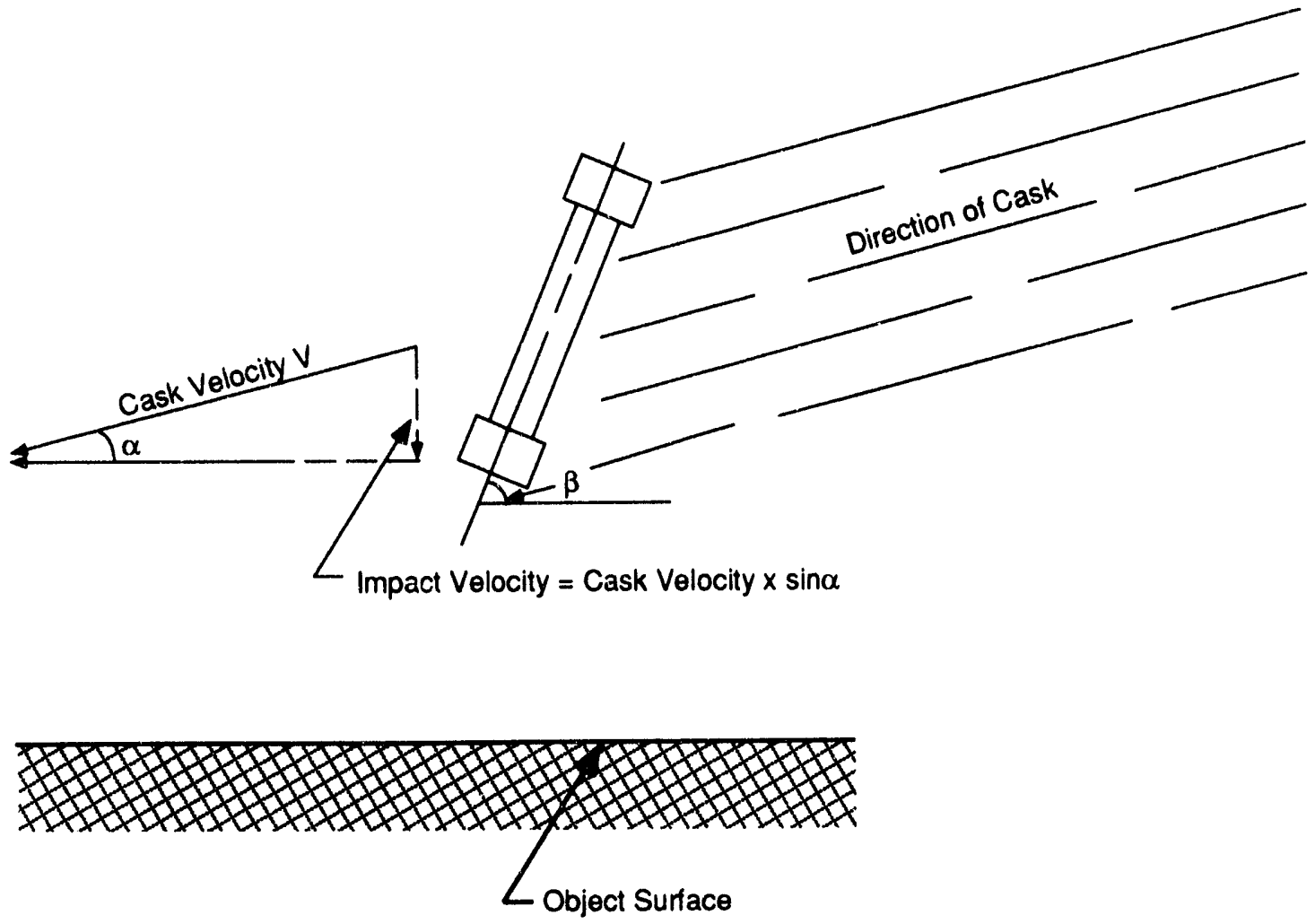

FIGURE E.3 Three Impact Loading Parameters Considered in the Response Analysis for Impacts on Surfaces (Modified from LLNL 1987, Figure 2.1)

TABLE E.1 Impact Velocities Required to Attain 0.2\%, 2\%, and 30\% Strain Levels for Objects Impacted in Highway and Railway Accidents ${ }^{\mathbf{a}}$

\begin{tabular}{|c|c|c|c|c|c|c|c|c|c|}
\hline \multirow{3}{*}{$\begin{array}{l}\text { Accident Type/ } \\
\text { Object Hardness }\end{array}$} & \multicolumn{9}{|c|}{ Impact Velocity (mph) at Various Strain Levels and Impact Angles } \\
\hline & \multicolumn{3}{|c|}{$\begin{array}{c}0.2 \% \text { Strain at } \\
\text { Three Angles }\end{array}$} & \multicolumn{3}{|c|}{$\begin{array}{l}2 \% \text { Strain at } \\
\text { Three Angles }\end{array}$} & \multicolumn{3}{|c|}{$\begin{array}{l}30 \% \text { Strain at } \\
\text { Three Angles }\end{array}$} \\
\hline & $0^{\circ}$ & $45^{\circ}$ & $90^{\circ}$ & $0^{\circ}$ & $45^{\circ}$ & $90^{\circ}$ & $0^{\circ}$ & $45^{\circ}$ & $90^{\circ}$ \\
\hline \multicolumn{10}{|l|}{ Highway } \\
\hline Unyielding & 32 & 35 & 38 & 51 & 49 & 46 & $>150$ & 113 & 76 \\
\hline Median & 32 & 35 & 38 & 51 & 49 & 46 & $>150$ & $>150$ & $>150$ \\
\hline Soft & 32 & 58 & 84 & 51 & 101 & $>150$ & $>150$ & $>150$ & $>150$ \\
\hline Very soft & 42 & $>150$ & 38 & 59 & $>150$ & 64 & $>150$ & $>150$ & $>150$ \\
\hline \multicolumn{10}{|l|}{ Railway } \\
\hline Unyielding & 55 & 47 & 38 & 72 & 60 & 48 & $>150$ & 128 & 105 \\
\hline Median & 55 & 47 & 38 & 72 & 60 & 48 & $>150$ & 128 & 105 \\
\hline Soft & 55 & 47 & 40 & 72 & 691 & 65 & $>150$ & $>150$ & $>150$ \\
\hline Very soft & 55 & $>150$ & 38 & 72 & $>150$ & 60 & $>150$ & $>150$ & $>150$ \\
\hline
\end{tabular}

a In the modal study (LLNL 1987), $150 \mathrm{mph}$ is defined as the maximum credible velocity.

Source: LLNL (1987). 


\section{E.2 THERMAL LOADS}

The temperature at the midlayer thickness of the lead shield (lead is the material assumed for the reference cask) was selected in the modal study as the appropriate parameter for characterizing thermal load response states. This temperature can be related to three accident parameters: fire duration, fire location, and flame temperature. Fire duration is the duration of the fire during the accident. Flame temperature, which usually ranges from 1,400 to $2,400^{\circ} \mathrm{F}$, is dependent on the burning materials and the amount of oxygen present in the flame. Fire location is determined by the relative distance from the fire to the cask. Fire location has been found to be an important factor in determining the thermal load. The heat load received by the cask can decrease by a factor of 4 for a fire $20 \mathrm{ft}$ from the cask compared with the heat load for an engulfing fire.

For casks with lead shielding, four discrete temperature response levels $-500,600$, 650 , and $1,050^{\circ} \mathrm{F}$ - are used to characterize the ranges of thermal response states and, therefore, the release potentials. The fire durations required to reach these four response states for a $1,700^{\circ} \mathrm{F}$ engulfing fire were estimated in the modal study (LLNL 1987). Table E.2 shows the results of the required fire durations for the $1,700^{\circ} \mathrm{F}$ engulfing fire to reach the four lead midlayer thickness temperatures. The response states for fires that deviate from the $1,700^{\circ} \mathrm{F}$ engulfing fire were examined in the modal study; the approach developed in that study to extrapolate the fire duration results estimated for the $1,700^{\circ} \mathrm{F}$ engulfing fire is presented in the following paragraphs.

TABLE E.2 Fire Duration Required to Reach the Four Levels of Lead Midlayer Thickness Temperatures for a $1,700^{\circ} \mathrm{F}$ Engulfing Fire

\begin{tabular}{|c|c|c|}
\hline \multirow{2}{*}{$\begin{array}{c}\text { Temperature } \\
\left({ }^{\circ} \mathbf{F}\right)\end{array}$} & \multicolumn{2}{|c|}{ Duration (h) } \\
\hline & Truck Cask & Rail Cask \\
\hline 500 & 1.1 & 1.2 \\
\hline 600 & 1.4 & 1.8 \\
\hline 650 & 2.1 & 2.7 \\
\hline 1,050 & 3.3 & 5.1 \\
\hline
\end{tabular}

Source: LLNL (1987). 
For a given fire scenario, the thermal response represented by the lead midlayer thickness temperature can be related to the fire duration, flame temperature, and fire location. The general equation developed in the modal study to extrapolate the thermal response of the $1,700^{\circ} \mathrm{F}$ engulfing fire to any other fire scenario is expressed as

$$
d_{F}(t, l)=\delta(t) d_{F}(1,700 f t)
$$

where $d_{F}(t, l)$ is the fire duration corresponding to a lead midlayer thickness temperature ${ }^{\circ} \mathrm{F}$ for flame temperat're $t$ and fire location 1 . The temperature multipiication factor, $\delta(t)$, is used to estimate the relative fire duration required for a flame temperature $t$ to fire a $1,700^{\circ} \mathrm{F}$ fire on the basis of the same thermal response in terms of lead midlayer thickness temperature. Values of $\delta(t)$ provided in the modal study are given in Table E.3. The distance multiplication factor, $\delta(1)$, is used to extrapolate the results of thermal response computed for the engulfing fire (distance $1=0$ ) to the away-from-the-cask fire (distance $=1$ ). For the representative truck cask, $\delta(l)$ is expressed as

$$
\delta(l)=0.78 \exp (0.7732+0.06287 \mathrm{l}) \text { for } \mathrm{l}>1.5 \mathrm{ft} .
$$

For the representative rail cask, $\delta(1)$ is expressed as

$$
\delta(l)=0.78 \exp (0.62874+0.08471 \mathrm{l}) \text { for } \mathrm{l}>4 \mathrm{ft} .
$$

\section{E.3 DETERMINATION OF RESPONSE REGIONS}

Cask responses during a transportation accident depend on the containment vessel strain and the lead midlayer thickness temperature. The potential responses have been partitioned into 20 response regions $R(i, j)(i=1,2,3,4 ; j=1,2,3,4,5)$ consisting of the combination of four structural response regions and five thermal response regions, as shown in Table E.4.

To determine an appropriate response region $[R(k, j)]$, the user must provide the following input parameters:

- Mechanical load accident parameters

- Cask velocity,

- Impact angle, 
TABLE E.3 Heat Flux

Factors for Flame

Temperatures

(engulfing fire)

\begin{tabular}{cl}
\hline $\begin{array}{c}\text { Flame } \\
\text { Temperature, } \mathrm{t} \\
\left({ }^{\circ} \mathrm{F}\right)\end{array}$ & $\delta(\mathrm{t})$ \\
\hline & \\
1,400 & 1.72 \\
1,500 & 1.43 \\
1,600 & 1.21 \\
1,700 & 1.0 \\
1,800 & 0.86 \\
1,900 & 0.73 \\
2,000 & 0.64 \\
2,100 & 0.56 \\
2,200 & 0.49 \\
2,300 & 0.44 \\
2,400 & 0.39 \\
\hline
\end{tabular}

Source: LLNL (1987).

TABLE E.4 Response Regions Categorized by Vessel Strain and Lead Midlayer Thickness Temperature

\begin{tabular}{|c|c|c|c|}
\hline \multicolumn{2}{|c|}{ Structural Response } & \multicolumn{2}{|c|}{ Thermal Response } \\
\hline Region (i) & Condition & Region (j) & Condition \\
\hline 1 & $<0.2 \%$ strain & 1 & $\begin{array}{l}<500^{\circ} \mathrm{F} \text { lead midlayer } \\
\text { thickness temperature }\end{array}$ \\
\hline 2 & $\begin{array}{l}0.2 \% \text { to } 2 \% \\
\text { strain }\end{array}$ & 2 & $\begin{array}{l}500 \text { to } 600^{\circ} \mathrm{F} \text { lead } \\
\text { midlayer thickness } \\
\text { temperature }\end{array}$ \\
\hline 3 & $\begin{array}{l}2 \% \text { to } 30 \% \\
\text { strain }\end{array}$ & 3 & $\begin{array}{l}600 \text { to } 650^{\circ} \mathrm{F} \text { lead } \\
\text { midlayer thickness } \\
\text { temperature }\end{array}$ \\
\hline \multirow[t]{2}{*}{4} & $>30 \%$ strain & 4 & $\begin{array}{l}650 \text { to } 1,050^{\circ} \mathrm{F} \text { lead } \\
\text { midlayer thickness } \\
\text { temperature }\end{array}$ \\
\hline & & 5 & $\begin{array}{l}>1,050^{\circ} \mathrm{F} \text { lead } \\
\text { midlayer thickness } \\
\text { temperature }\end{array}$ \\
\hline
\end{tabular}


- Cask orientation, and

- Hardness of the impacted object.

- Thermal load accident parameters

- Fire duration,

- Flame temperature, and

- Fire location with respect to the cask.

The flow diagram to relate the accident parameters to the appropriate response region is given in Figure E.4. All of the threshold or bounding accident parameters used in this algorithm follow those provided in the modal study (LLNL 1987). For accident parameters that are not equal to the threshold values, linear interpolation between the two bounding values is assumed to be appropriate. 


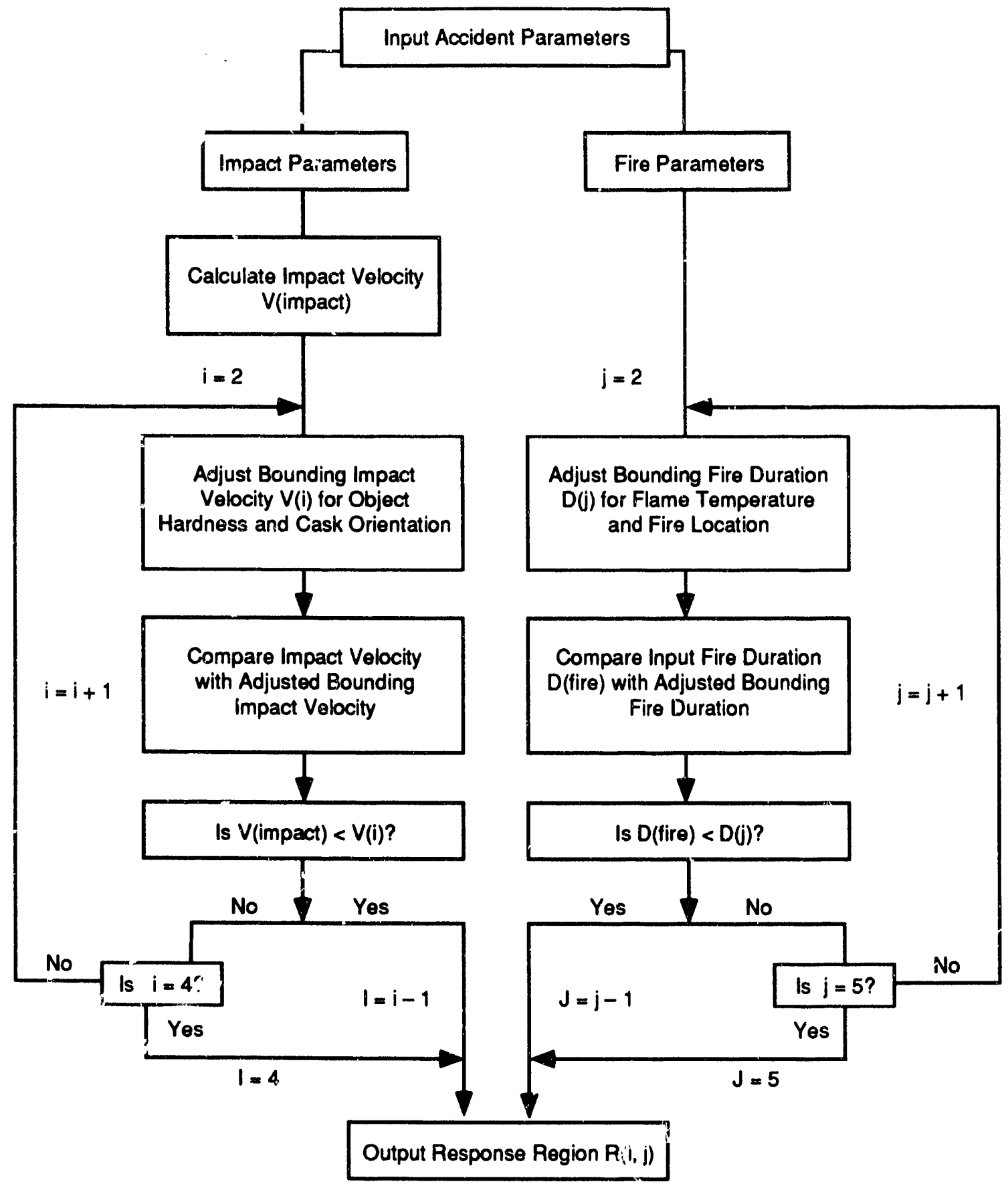

FIGURE E.4 Flow Diagram Used in RISKIND to Determine Cask Response Regions 


\section{APPENDIX E REFERENCE}

Lawrence Livermore National Laboratory, Shipping Container Response to Severe Highway and Railway Accident Conditions, NUREG/CR-4829, prepared for U.S. Nuclear Regulatory Commission, Feb. 
APPENDIX F:

\section{PROGRAM STRUCTURE}




\section{APPENDIX F: \\ PROGRAM STRUCTURE}

Information related to the program structure and data transfer used in RISKIND is provided in this appendix. RISKIND is composed of the main program, subroutines, and utility function modules. Data transfer is performed primarily through labeled common blocks. The default values of the data used by RISKIND are defined in two block-data subroutines, INIT1 and INIT2.

\section{F.1 HIERARCHY}

The hierarchy of the modules in RISKIND is given in Figures F.1 through F.7. These diagrams represent calling sequences and give a brief description of the purpose of each module. In addition to the modules shown in the hierarchy diagrams, RISKIND also uses three output routines. These routines are used by other modules to write program outputs.

\section{F.2 COMMON BLOCKS}

Most of the data transfers among modules are handled through labeled common blocks. RISKIND uses numerous labeled common blocks; some of the major blocks are listed in Table F.1. 


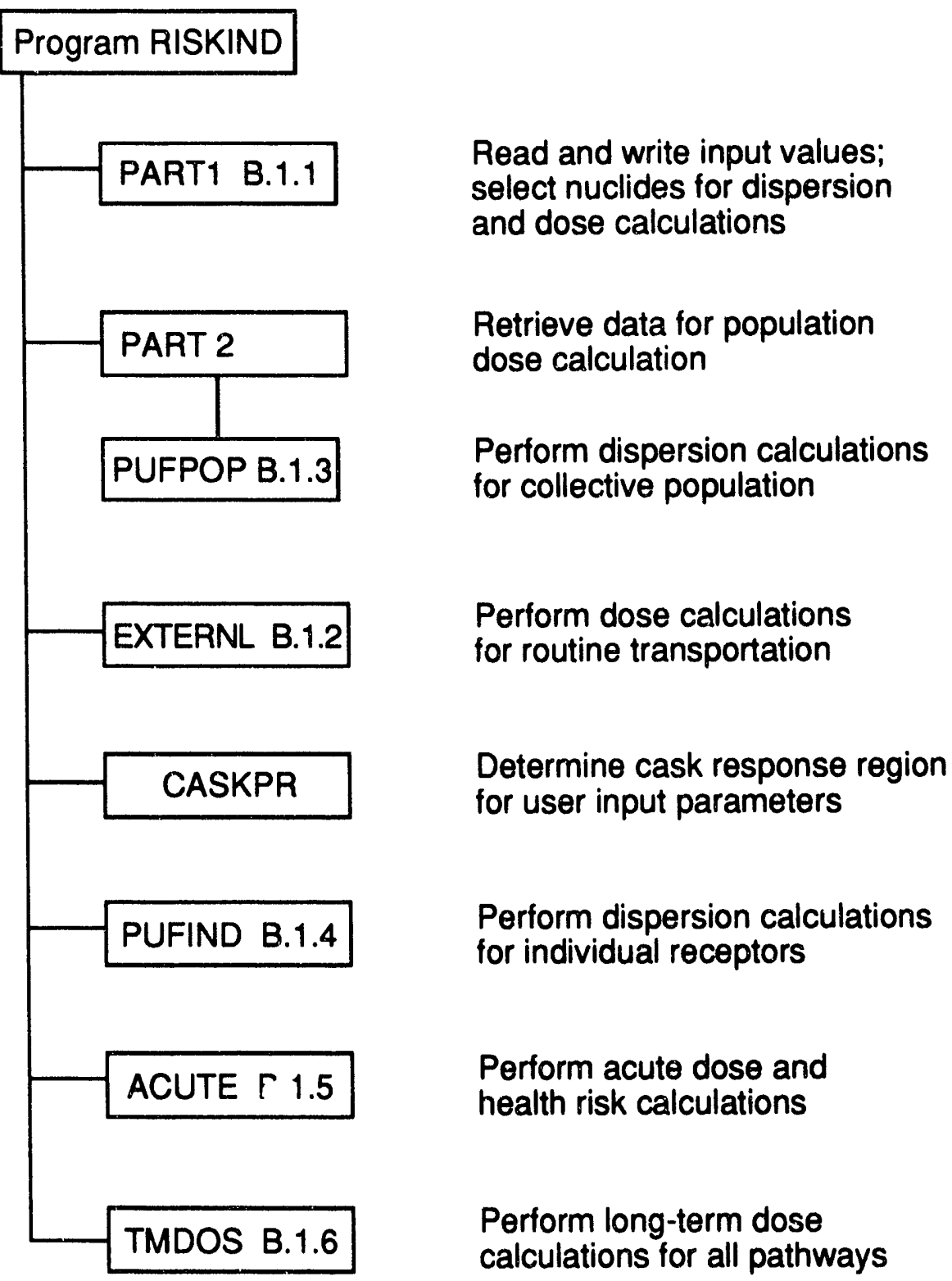

FIGURE F.1 Hierarchy Diagram for Main RISKIND Program 


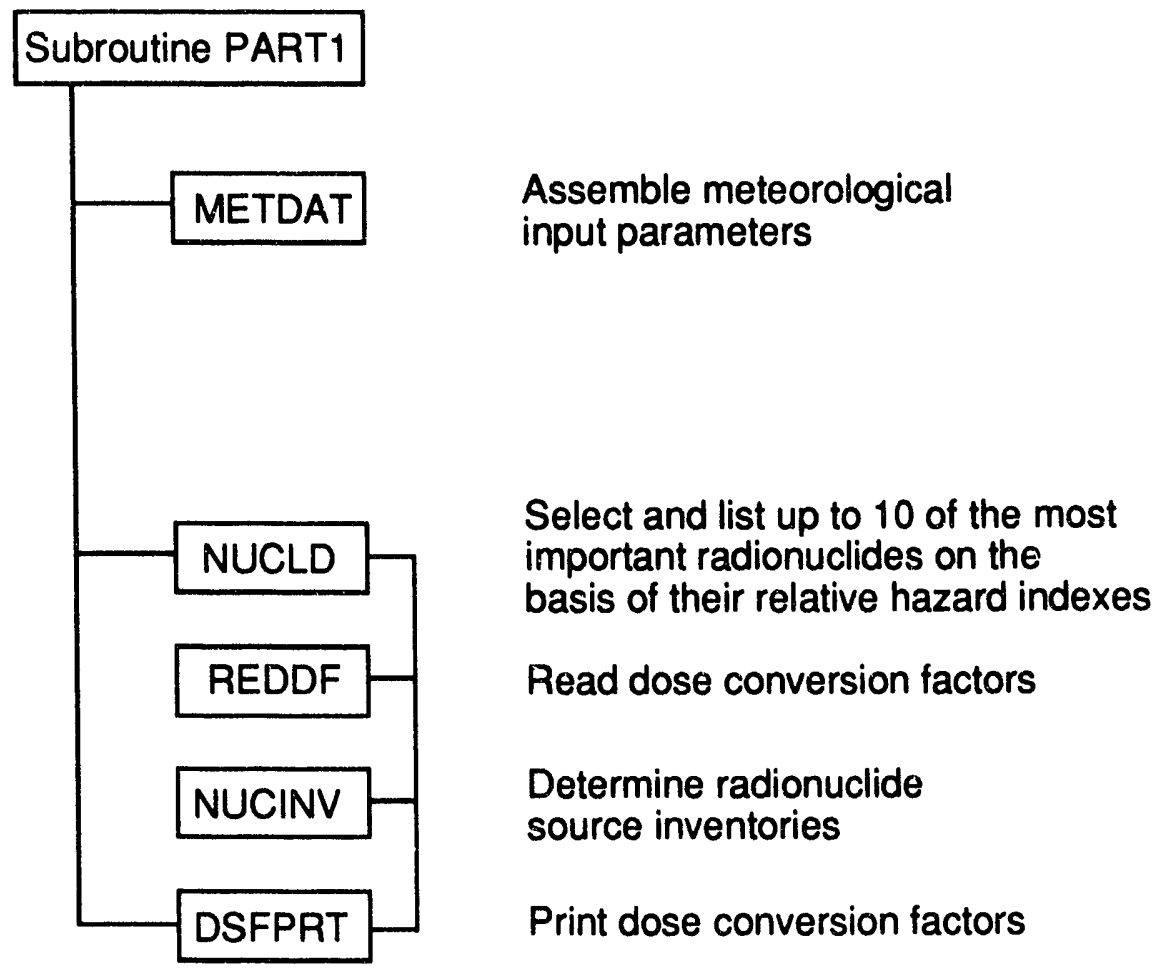

FIGURE F.2 Hierarchy Diagram for Subroutine PART1 


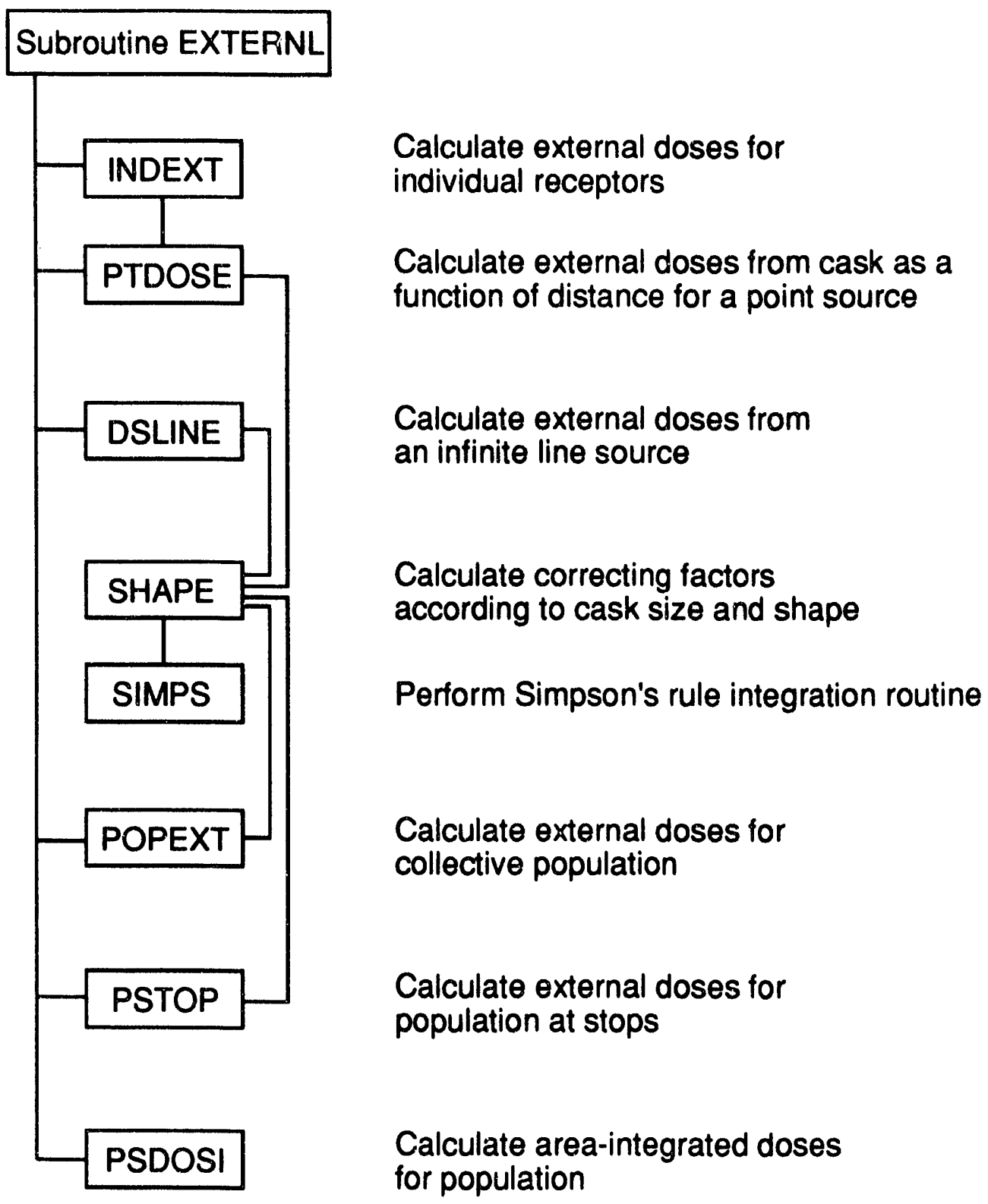

FIGURE F.3 Hierarchy Diagram for Subroutine EXTERNL 


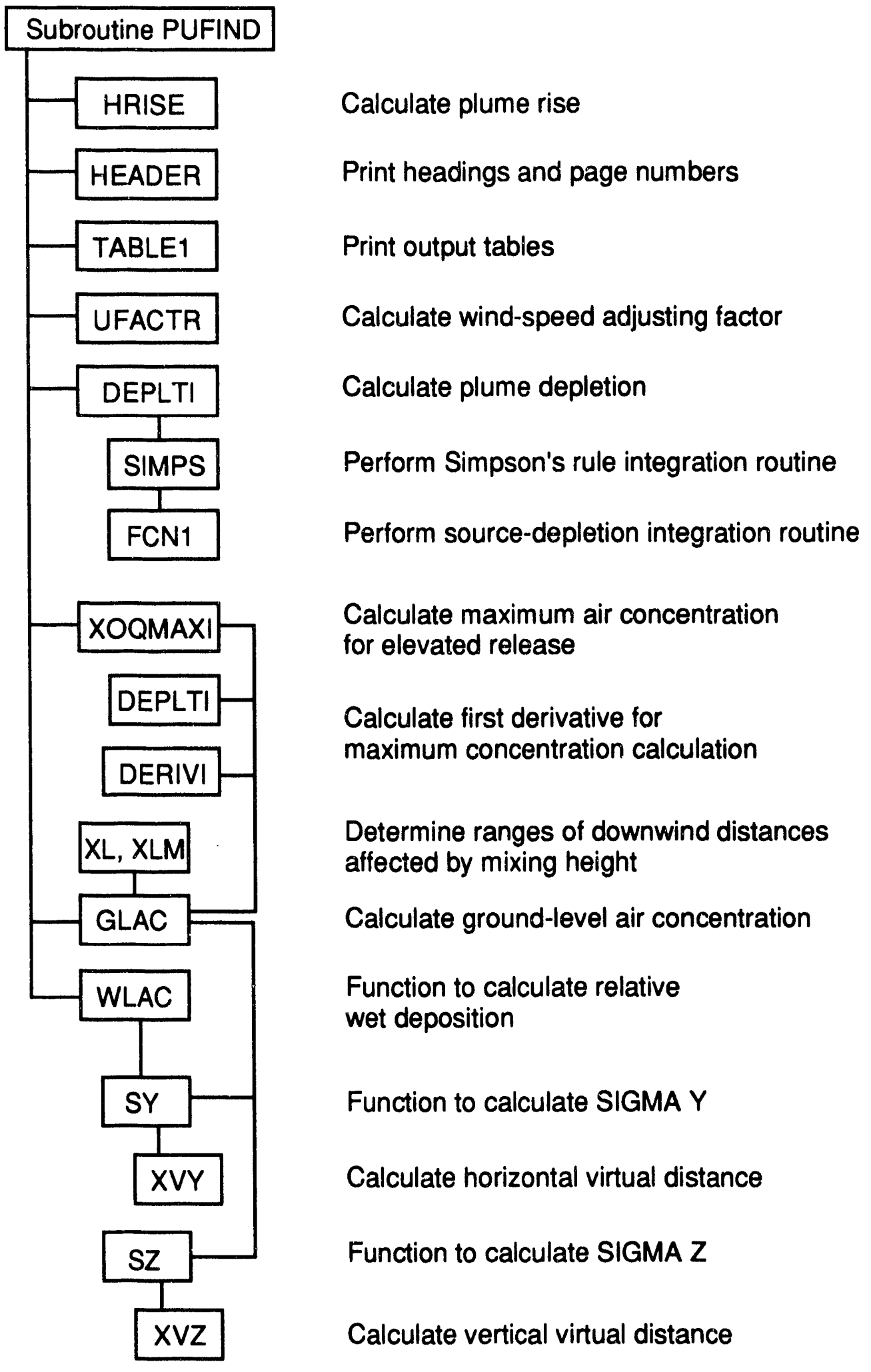

FIGURE F.4 Hierarchy Diagram for Subroutine PUFIND 
Subroutine ACUTE

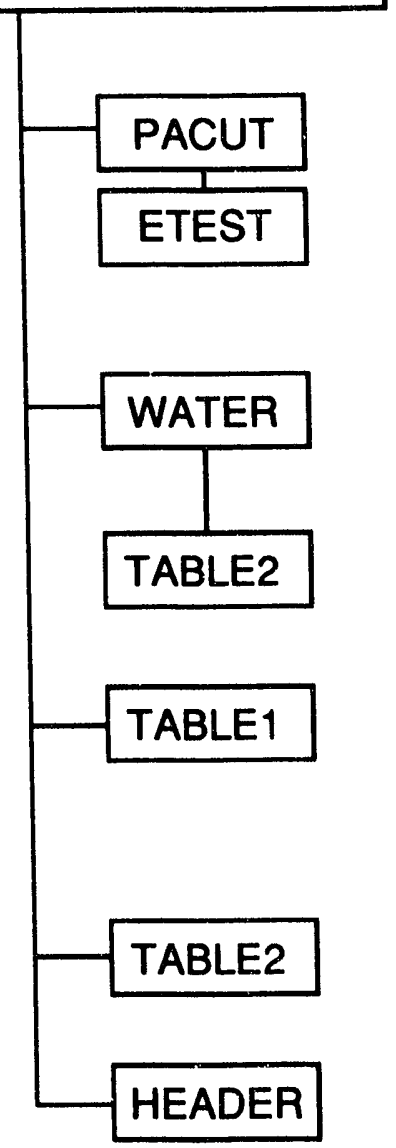

Calculate early health effects

Function to test for exponential overflow

Calculate concentrations in water and doses from drinking

Print receptor-dependent output parameters

FIGURE F.5 Hierarchy Diagram for Subroutine ACUTE 


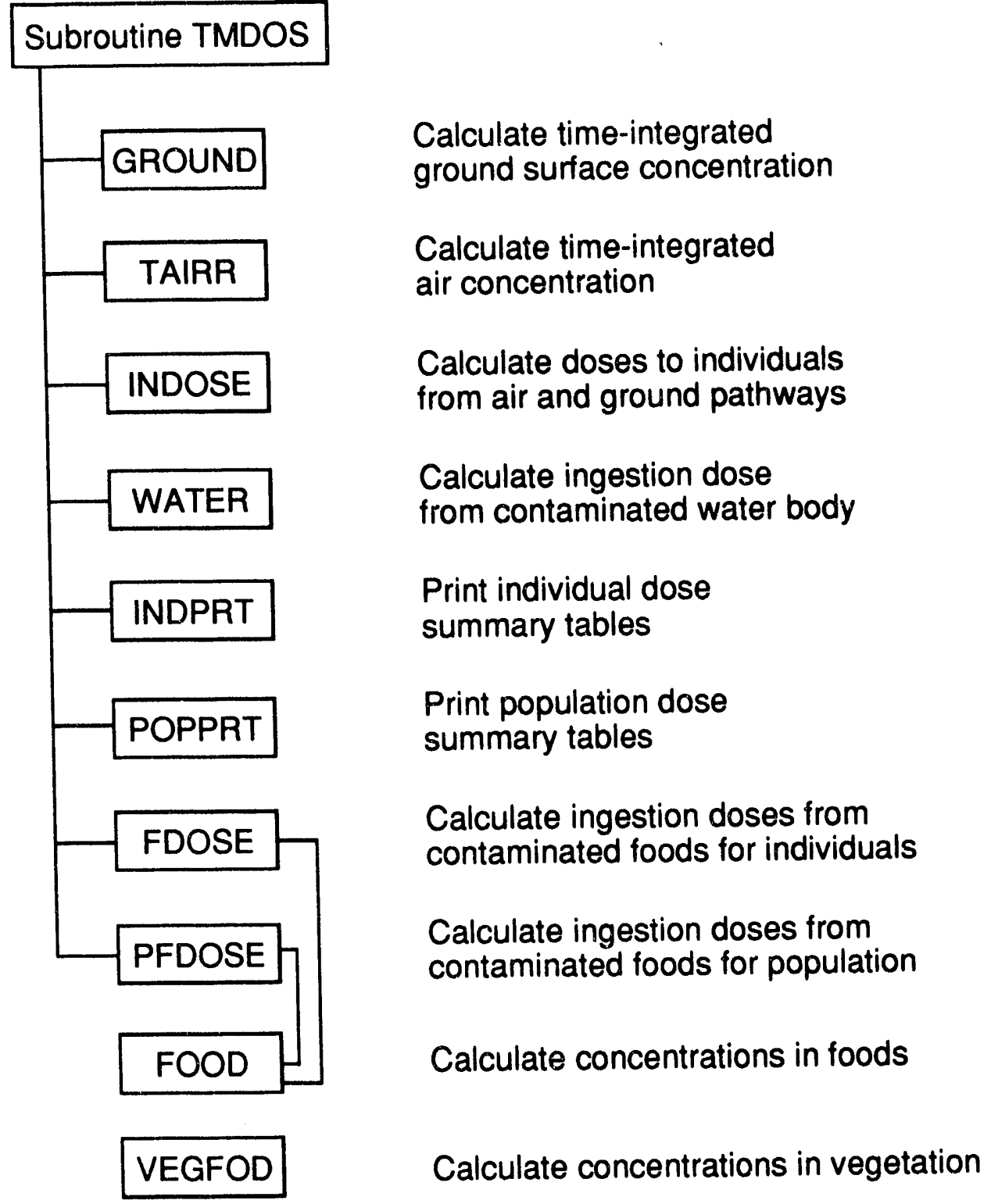

FIGURE F.6 Hierarchy Diagram for Subroutine TMDOS 


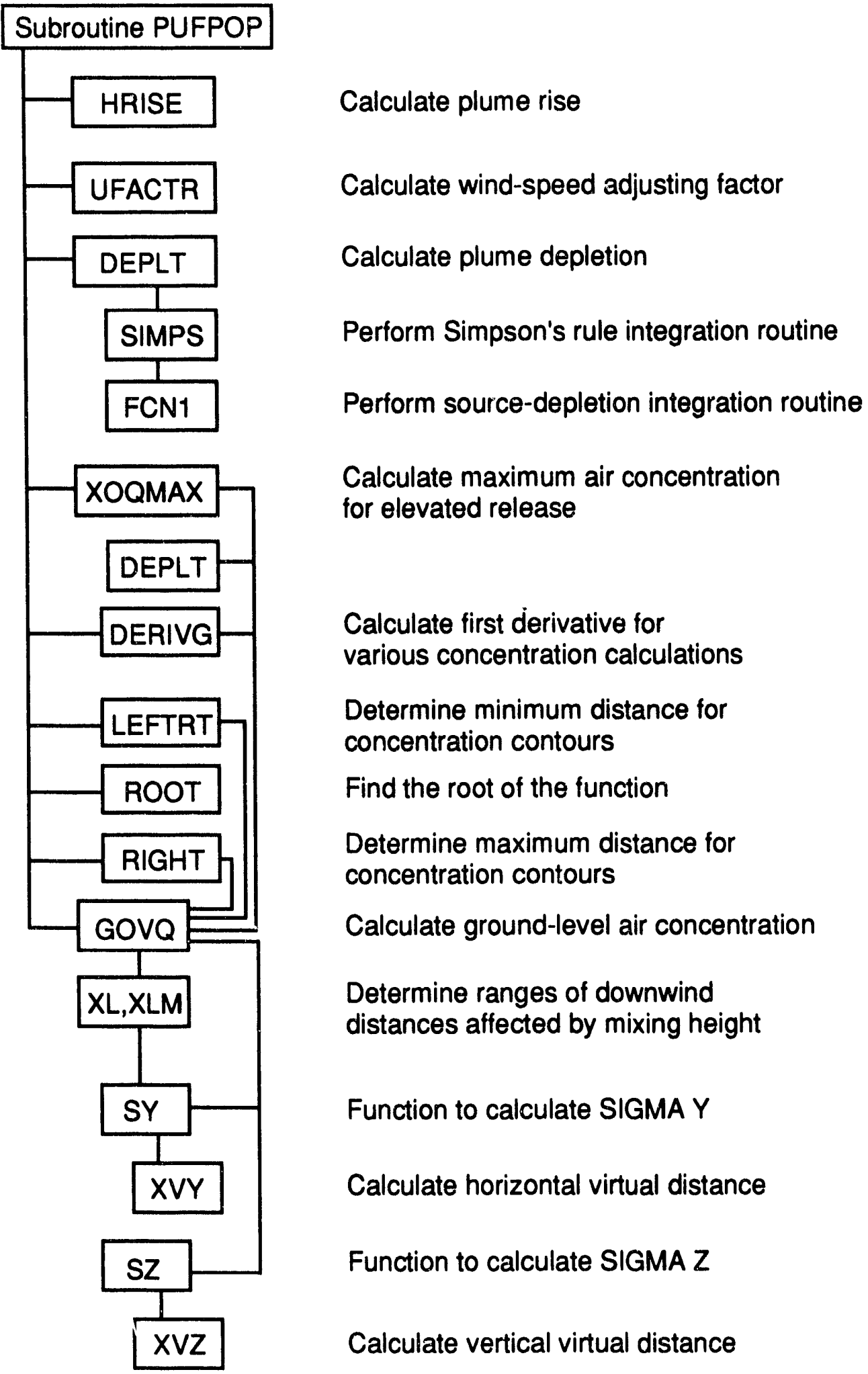

FIGURE F.7 Hierarchy Diagram for Subroutine PUFPOP 
TABLE F.1 Major Common Blocks Used in RISKIND

\begin{tabular}{ll}
\multicolumn{1}{c}{ Block } & \multicolumn{1}{c}{ Type of Parameter } \\
\hline BLOCK DATA INIT1 & \\
ADT & Accident-related parameters \\
CFOD & Food pathway parameters \\
DCASK & General cask information, including external dose \\
& coefficients \\
DFLIB & Radionuclide database \\
DKAY & Source, radiological, and weathering decay coefficients \\
DSPR & Meteorological data \\
EXT2 & Input and output files \\
EVD & Dose calculation results \\
PARAM & Meteorological and dispersion parameters \\
RLINE & Cask shielding parameters, including external dose \\
RDADC1 & rates \\
RDADC2 & Exposure pathway parameters \\
RDADC3 & Shipment data and accident probability \\
RDADC4 & Dose factors \\
SOURCE & Radionuclide concentrations and acute effects \\
STATED & Source, accident parameters \\
WATPTH & State accident statistics \\
XDOQ & Water pathway parameters \\
& Receptor information and dispersion calculation \\
BLOCK DATA INIT2 & results \\
ELEMEN & \\
TRANFR & Elementary data \\
NUCLID & Elementary transfer coefficients \\
QSDATA & Nuclide data \\
\hline & Isotope data \\
\hline
\end{tabular}


APPENDIX G:

DATA INPUT PREPARATION 


\section{APPENDIX G:}

\section{DATA INPUT PREPARATION}

The system module (RISKIND) will run on any IBM (or compatible) microcomputer with a 3.1 or equivalent disk operating system (DOS), a hard disk drive, approximately 550 kilobytes (K) of available memory, and a math coprocessor. The RISKIND module consists of two major components:

1. RISKINP.EXE - A compiled BASIC (Microsoft 7.1*) program that handles all user interaction with RISKIND. The user may input selected run-specific data files, review and/or modify the parameters, save the data in a selected file, view and/or print selected results from the latest run, and execute RISKIND.EXE (see below).

2. RISKIND.EXE - A Fortran (Lahey F77L $4.1^{\dagger}$ ) program that receives an input file from RISKIND, performs all subsequent radiological calculations, and generates output files.

\section{G.1 INSTALLATION AND OPERATION OF RISKIND}

The RISKIND code is available on a single 1.44-megabyte (MB) 3.5-in. diskette. This diskette should be inserted into the disk drive. The user should set up a subdirectory on the hard disk to contain the files necessary for the RISKIND system (e.g., \RISKIND); to do this $C D C: \backslash$ must be typed, follow by MKDIR RISKIND. The default to this directory can be set with the command $C D C: \backslash R I S K I N D$. To install the RISKIND system, $A:$ RISKIND (assuming that the RISKIND disk is in drive A:) must be typed. The files will be created in this directory on the hard disk.

The RISKIND program can be operated by going to the directory and typing RISKIND. The RISKIND Main Menu (Figure G.1) will appear. The problem is defined through the input parameters entered with the help of these input screens.

\footnotetext{
* Micrnsoft Corporation, 1990, Microsoft BASIC 7.1, Redmond, Wash.

$\dagger$ Lahey Computer Systems Inc., 1990, Lahey F77L 4.1, Incline Village, Nev.
} 


\section{G.2 INPUT REQUIREMENTS}

The RISKIND system is a menu-driven program that consists of a main menu with 10 major input data categories and two major function categories (Figure G.1). The input data categories are described below. Some data categories require input on multiple screens. These screens will appear at the appropriate time, if necessary, for problem definition. The input from the screens is collected and stored in a file in FORTRAN NAMELIST format. This file is then used for input to the FORTRAN program RISKIND, which performs the numerical calculations. Descriptions of the NAMELIST input parameters are provided in Table G.1.

Category 1 input parameters describe the type of problem to be solved and the files used for default and final storage (Figure G.2).

Category 2 input parameters describe the spent fuel shipping cask in terms of its capacity, size, annual shipment, transport index, and crud parameters (Figure G.3).

Category 3 input parameters specify the transport methods, such as mode, road type, population zone, and speed (Figure G.4).

Category 4 input parameters specify accident probability and release data (Figure G.5). An additional screen is available for loss of shielding during an accident (Figure G.6). If the user specifies a specific scenario (IYOURS = -1), then another screen will appear to define that scenario (Figure G.7).

Category 5 input parameters specify meteorological data and dispersion parameters (Figure G.8). The next screen depends on whether the problem is to use a specific wind speed and stability (IYOURW=1; Figure G.9) or an average over historical weather conditions (IYOURW = 0; Figure G.10). A further screen will appear if IMET = 1, that is, the user inputs the wind frequencies directly (Figure G.11); otherwise, the meteorological data will be read from a previously prepared file.

Category 6 input parameters specify receptor location-related parameters. If the problem concerns individuals, a screen will prompt for the individual parameters (Figure G.12); otherwise, a screen will appear defining water bodies for the population exposure problem (Figure G.13). 
RISKIND: Computer Code for Transportation Risk Assessment

RISKIND Main Menu

Major Data and Function Categories

1. Files, Title, and state Identification

2. Spent Fuel Source Term and Cask Information

3. Traffic Mode Information

4. Accident Probablity and Release Data

5. Meteorological Data and Dispersion Parameters

6. Receptor Location Related Parameters

7. Population Parameters

8. Population Parameters- Ingestion

9. Long Term Exposure Pathway Data

10. Output Options

11. Execute the Code

12. View Output

Enter 1-12 from above 1 ist to select data or function category: : or press "FI" or "F2" for HELP, or "Esc" to EXIT from RISKIND system.

\%:.

\section{G.1 Main Menu of RISKIND System}

Category 7 input parameters specify general population information (Figure G.14). The additional information for population runs for incident-free problems is defined through the screen shown in Figure G.15.

Category 8 input parameters specify population information needed for ingestion considerations (Figure G.16). The long-term exposure parameters are defined with the next category (Figure G.17).

The last screen defines parameters for the output of the results (Figure G.18). 
TABLE G.1 Description of Input Parameters

Input

Parameter

Description

\&INDATA NAMELIST data input string for RISKIND.

ACTA Accident probability: if ACTA $<0$, use code-provided state-averaged value.

Default: 1 (consequence analysis).

PAG Long-term dose value for determining cleanup levels for

individual (mrem/50-yr).

Default: 5,000 .

GROUP(20) Statement of no more than 20 letters for output identifier.

Default: 'TRUCK.'

STATEN(14) State name.

Default: 'Utah.'

TITLE(48) Statement of no more than 48 letters for job title.

Default: 'Modal Study.'

FATA Accident fatality rate: if FATA $<0$, use code-provided value.

Default: -1.0.

HS Physical release height (m).

Default: 1.0 .

HZLM Radionuclide selection criterion: HZLM $<0.1$.

Default: 0.01 (or 1\%).

IACDT Flag for accident calculation:

$>0$, perform accident calculation;

$\leq 0$, no accident calculation.

Default: 1 .

IACFOD Flag for disposal of initially contaminated foodstuffs:

$>0$, no (calculate ingestion dose from initially contaminated foods);

$\leq 0$, yes (do not calculate ingestion dose from initially contaminated foods).

Default: 0 .

IBOUND Flag for level of conservatism in health risk calculations:

$1=$ lower bounds

2 = central estimates

$3=$ upper bounds.

Default: 2.

IMOD Transportation mode:

$1=$ truck

$2=$ rail

$3=$ others.

Default: 1. 
Input Parameter

\begin{tabular}{|c|c|c|c|c|}
\hline IRDTY & \multicolumn{4}{|l|}{$\begin{array}{l}\text { Road type: } \\
1=\text { interstate highway } \\
2=\text { primary road } \\
3=\text { secondary road. } \\
\text { Default: } 1\end{array}$} \\
\hline IRUTIN & \multicolumn{4}{|l|}{$\begin{array}{l}\text { Flag for routine dose calculation: } \\
>0 \text {, perform routine dose calculation; } \\
\leq 0 \text {, no routine calculation. } \\
\text { Default: } 1 \text {. }\end{array}$} \\
\hline ITREAT & \multicolumn{4}{|l|}{$\begin{array}{l}\text { Flag for level of medical treatment: } \\
1=\text { minimal treatment } \\
2=\text { supportive treatment. } \\
\text { Default: } 1\end{array}$} \\
\hline ISTATE & 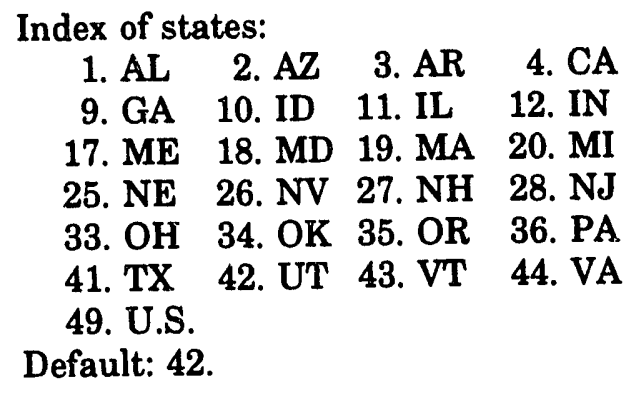 & $\begin{array}{ll}\text { 5. CO } & \text { 6. CT } \\
\text { 13. IA } & \text { 14. KS } \\
\text { 21. MN } & \text { 22. MS } \\
\text { 29. NM } & \text { 30. NY } \\
\text { 37. RI } & \text { 38. SC } \\
\text { 45. WA } & \text { 46. WV }\end{array}$ & $\begin{array}{l}\text { 7. } \mathrm{DE} \\
\text { 15. KY } \\
\text { 23. MO } \\
\text { 31. NC } \\
\text { 39. SD } \\
\text { 47. WI }\end{array}$ & $\begin{array}{l}\text { 8. FL } \\
\text { 16. LA } \\
\text { 24. MT } \\
\text { 32. ND } \\
\text { 40. TN } \\
\text { 48. WY }\end{array}$ \\
\hline IZONE & \multicolumn{4}{|c|}{$\begin{array}{l}\text { Population zone category: } \\
0 \leq \text { population zone determined by population density input (POPD) } \\
1 \text { = rural } \\
2=\text { suburban } \\
3=\text { urban. } \\
\text { Default: } 1\end{array}$} \\
\hline $\begin{array}{c}\mathrm{JC}(2) \\
\mathrm{i}\end{array}$ & \multicolumn{4}{|c|}{$\begin{array}{l}\text { Flags for output print options: } \\
1 \text { for print, } 0 \text { for no print; } \\
i=1 \text {, print summary output for each accident; } \\
i=2 \text {, print detail output for each accident. } \\
\text { Default: } 0,0 \text {. }\end{array}$} \\
\hline NGRF & \multicolumn{4}{|c|}{$\begin{array}{l}\text { Dose risk graphic output file name of no more than } 24 \text { letters. } \\
\text { Default: 'RISK.GRF.' }\end{array}$} \\
\hline HEADING & \multicolumn{4}{|c|}{$\begin{array}{l}\text { Dose risk graphic output heading of no more than } 24 \text { letters. } \\
\text { Default: 'Dose/Risk.' }\end{array}$} \\
\hline
\end{tabular}


TABLE G.1 (Cont.)

Input

Parameter

Description

NHEAD Number of letters in graphic output headings.

Default: 24.

OUTFIL(32) Output file name.

Default: 'sample.out.'

PBUNIT(6) Unit of probability input value for ACTA.

Default: '1/km.'

PHALF Radionuclide removal half-life from soil (yr).

Default: 50.

RSALF Resuspension factor decay half-life (yr);

Default: 0.137 .

$\operatorname{SEXT}(20,2) \quad$ Accidental external dose multiplication factor due to loss $(i, j)$ of shielding, expressed in multiples of $\mathrm{TI}$ :

$\mathrm{i}=$ accident-response region

$\mathrm{j}=1$, gamma

$\mathrm{j}=2$, neutron.

Default: $40^{*} 1$.

SPEED Vehicle travel speed during normal transport $(\mathrm{km} / \mathrm{h})$;

if $<$ or $=0$, use code-provided value.

Default: -1 .

SUFI Initial resuspension factor $(1 / \mathrm{m})$.

Default: $1 \times 10^{-5}$.

SUFF Final resuspension factor $(1 / \mathrm{m})$.

Default: $1 \times 10^{-9}$.

DR2M Dose rate in $\mathrm{mrem} / \mathrm{h}$ at $2 \mathrm{~m}$ from cask surface.

Default: 10.

VDEP Ground deposition velocity of particulates $(\mathrm{m} / \mathrm{s})$.

Default: 0.001 .

VDVEG Average ground deposition velocity of 1-micron particles during plume passage through farmland $(\mathrm{m} / \mathrm{s})$.

Default: 0.01 .

WDEP Water surface deposition velocity $(\mathrm{m} / \mathrm{s})$.

Default: $\mathbf{0 . 0 2}$. 
TABLE G.1 (Cont.)

Input

Parameter

Description

YEVD Number of years for calculating long-term individual dose commitment from released contamination (yr).

Default: 50.0 .

NAMELIST data input string for nuclear shipment-related parameters.

BURNUP Reactor fuel burnup (MWd/MTIHM).

Default: 35,000.

CACTD Crud surface activity density of cask $\left(\mu \mathrm{Ci} / \mathrm{cm}^{2}\right)$ :

if -1 , use code-provided value.

Default: 1.

CAREA Total surface area of cask cavity, including fuel $\left(\mathrm{m}^{2}\right)$ :

if -1 , use code-provided value.

Default: 39.

CVOID Volume of void in cask $\left(\mathrm{m}^{3}\right)$ :

if -1 , use code-provided value.

Default: 0.155 .

FRAD(2) Fraction of dose rate (at $2 \mathrm{~m}$ from the vehicle surface) contributed by neutron and gamma radiations:

$\mathrm{i}=1$, gamma

$i=2$, neutrons.

Default: $0.60,0.40$.

HSIZE Length of cask (m).

Input HSIZE = 0, use code-provided value.

Default: 6.97 .

RSIZE Radius of cask (m).

Input RSIZE = 0, use code-provided value.

Default: 0.97 .

RTYPE Reactor type for spent fuels (BWR or PWR).

Default: 'PWR.'

TFUEL Spent fuel cooling time (yr).

Default: 10.

TYPCSK Label of no more than 20 letters for type of cask.

Default: 'Modal truck.'

UMT Total uranium in cask (MTU).

Default: 0.46 . 
TABLE G.1 (Cont.)

Input

Parameter

Description

NAMELIST data input string start for receptor location-related parameters.

IADD Number of receptor location for which individual doses will be calculated;

IADD also serves as the indicator for either individual dose runs (IADD $>0$ ) or collective dose runs (IADD $=0$ ).

$0<$ IADD $<20$.

Default: 1 .

INDR(20) Flag for either indoor or outdoor exposure for each receptor:

$1=$ indoor exposure

$0=$ outdoor exposure.

Default: $20 * 0$.

IDFOOD(20) Flag for food pathway for each receptor:

if 1 , include food pathway

if 0 , no food pathway.

Default: $20 * 1$.

IRTP(20) Pathway indicator for each receptor:

1: all pathway ( for both acute and long-term exposure)

2: acute exposure only (plume passage).

Default: $20 * 1$.

ISHLT(20) Type of shelter for each receptor:

1: frame house

2: brick house

3: office building

4: cars on road.

Default: $20 * 1$.

IWATER(20) Flags for water pathway indicator for each receptor:

$0=$ no water path way considered

1 = water pathway considered.

Default: $20 * 0$.

$\operatorname{OCUPF}(20, \mathrm{i}) \quad$ Indoor $(i=1)$ and outdoor $(i=2)$ occupancy factor for each receptor for calculating long-term doses.

Default: $20 * 0.5$ (indoors), $20 * 0.25$ (outdoors).

POPW(20) Number of people consuming water from each receptor (only used for population dose calculation).

Default: $20 * 1$.

TEXT(20) Duration of exposure for each receptor after accident has occurred (h).

Default: $20 * 2.0$.

TSTP(20) Duration of stop at each receptor (h).

Default: $20 * 1.0$. 
TABLE G.1 (Cont.)

Input

Parameter

Description

WBDYD(20) Depth of water body at each receptor $(m)$.

Default: $20 * 2.0$.

WBDYW(20) Cross-wind width of water body at each receptor $(\mathrm{m})$.

Default: $20 * 50$.

WEXCG(20) Water body exchange rate per year.

Default: $20 * 1$.

XRECEP $(3,20)$ Individual receptor location coordinates:

$\operatorname{XRECEP}(1, i)$, downwind distance $(\mathrm{km})$

$\operatorname{XRECEP}(2, \mathrm{i})$, crosswind distance $(\mathrm{km})$

$\operatorname{XRECEP}(3, \mathrm{i})$, elevation of receptor $(\mathrm{m})$.

Default: $1.0,0 ., 0$, and $57 * 0$.

XNAME(20) Label for individual receptor location $i$, use up to 20 letters for each receptor. Default: 'DEFAULT RECEPTOR 1.'

NAMELIST data input string start for meteorological parameters.

ANH Anameter height (m).

Default: 10.0 .

TABK Ambient temperature (K).

Default: 288.

IYOURW Meteorological data input option:

1: input user-provided wind speed and stability

0 : use default wind frequency data set.

Default: 0 .

If IYOURW $=1$, Input the following parameters:

DMIX If 0 , mixing height (m), use am and pm mixing heights.

Default: 800 .

ITYPE Pasquill atmospheric stability categories

(1 - 6 corresponding to Pasquill stability categories A - F).

Default: 4.

RAIN Rainfall rate $(\mathrm{mm} / \mathrm{h})$.

Default: 0.0 .

WSM Wind speed measured at anameter height $(\mathrm{m} / \mathrm{s})$.

Default: 4.0 . 
TABLE G.1 (Cont.)

Input

Parameter

Description

If IYOURW $=0$, input the following parameters:

AMIX Annual average morning mixing height (m).

Default: 300.

PMIX Annual afternoon mixing height (m).

Default: 2,400 .

IMET Input option of wind frequency data:

IMET = 1: input wind frequency data in fractions in 6 wind-speed and 6 stability classes, DFREQ $(6,6)$;

IMET $=0$ : input wind frequency data in 6 wind-speed and 6 stability classes and 16 wind directions, FREQ $(6,6,16)$.

IFREQ 1: Input wind frequency data FREQ in fractions

0 : Input wind frequency data FREQ in percent

Default: 1 .

DFREQ $(6,6)$ Fractional frequency of occurrence of wind-speed class $(6)$ and atmospheric stability class(6) (only if IMET $=1$ ).

Default: $36^{*} 0.0278$.

FREQ $(6,6,16)$ Fractional or percent joint frequency of occurrence of wind-speed class $(6)$, atmospheric stability class(6), and wind direction(16) (only if IMET $=0$ ). Default: $576 * 0.001736$.

WS(6) Average wind speeds for the six wind-speed classes of the wind frequency data $(\mathrm{m} / \mathrm{s})$.

Default: $0.67,2.46,4.47,6.93,9.61,12.52$.

NAMELIST data input string for ingestion-pathway-related parameters.

DFACT Decontamination factor for human-consumed vegetation.

Default: 0.5 .

FG Grazing factor.

Default: 0.5 .

PFIN(3) Fractions of each type of food grown on the contaminated ground consumed by individuals:

$\mathrm{i}=1$, meat

$i=2$, milk

$i=3$, vegetation.

Default: $3 * 1.0$. 
TABLE G.1 (Cont.)

Input

Parameter

Description

TREATM Efficiency of treatment used for contaminated water (currently not used).

Default: 0.0 (no treatment).

XIN(3) Individual food consumption rate $(\mathrm{kg} / \mathrm{d})$ for individual dose calculations

(IADD >0).

Defaulis:

$\mathrm{i}=1$, meat

$\mathrm{XIN}(1)=0.30$

$\mathrm{i}=2$, milk

$\mathrm{XIN}(2)=0.85$

$\mathrm{i}=3$, vegetation $\quad \mathrm{XIN}(3)=0.77$.

XINW Individual drinking water intake (L/d).

Default: 1.0 .

NAMELIST data input string for accident-related parameters.

IYOURS Flag for accident scenario input:

-1: input your own accident parameters

0 : use all (1 to 20) NRC modal study response regions

i: use $i$ th (1 to 20) NRC modal study response region.

Default: 0 .

If IYOURS $=1$, input the following parameters:

VCASK Accident cask velocity (mph).

Default: 40.

ALPHA Cask impact angle $\left({ }^{\circ}\right)$.

Default: $90^{\circ}$.

BETA Cask orientation angle $\left({ }^{\circ}\right)$.

Default: $90^{\circ}$.

IHARD Impact object hardness index:

1: unyielding

2: medium

3: soft

4: very soft.

Default: 1.

TFLAME Flame temperature $\left({ }^{\circ} \mathrm{F}\right)$.

Default: 1,700 . 
TABLE G.1 (Cont.)

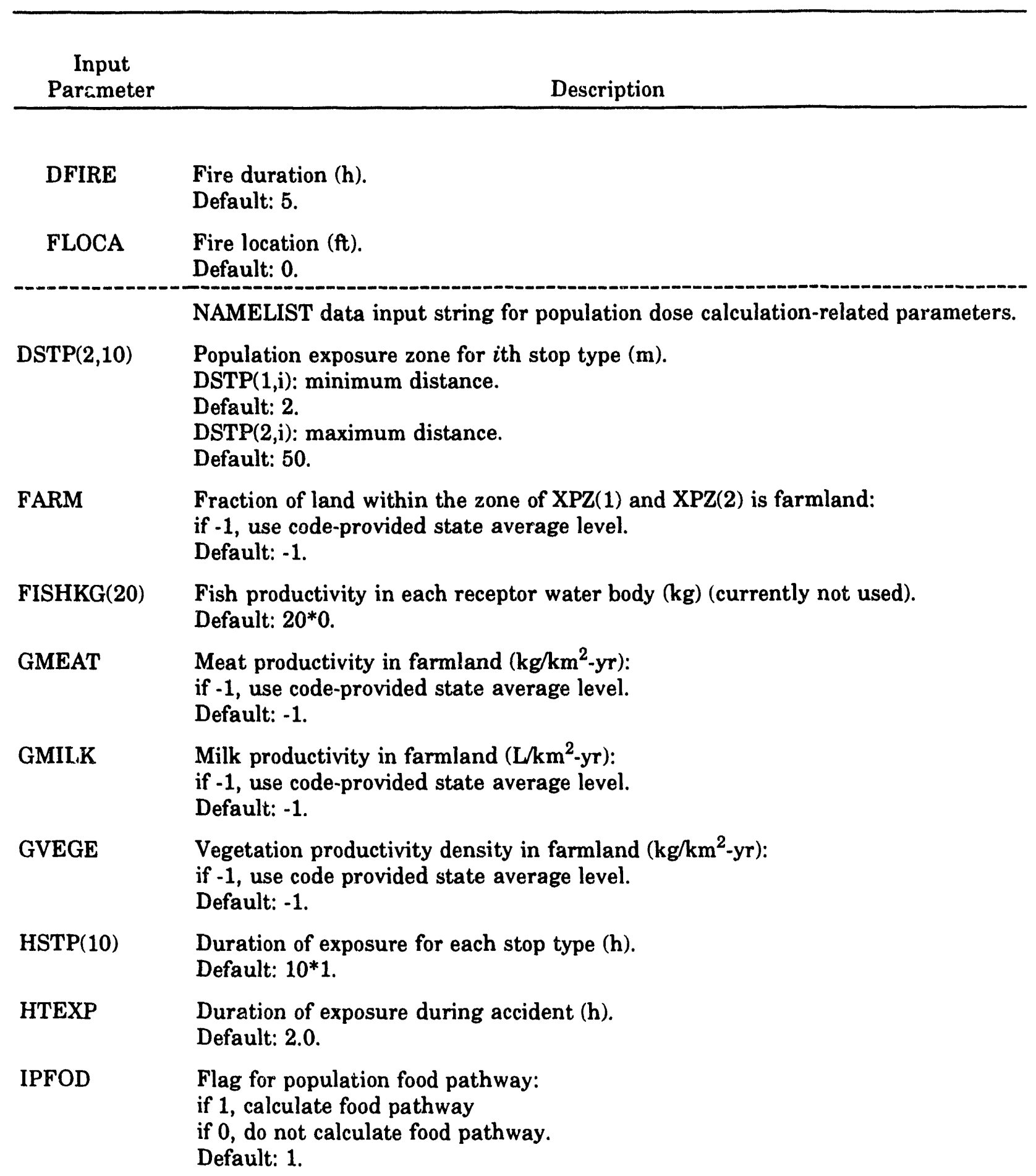


TABLE G.1 (Cont.)
Input
Parameter
Description

IPWATR Number of water body locations for population drinking water dose calculations. The user uses XRECEP and YRECEP to input the coordinates of each location. Default: 0.

NSTP(10) INumber of stops for $i$ th stop type.

i Default: $10 * 1$.

NSTY Number of stop types.

Default: 1.0 .

$\operatorname{OCUPF}(20,2)$ Indoor $(j=1)$ and outdoor $(j=2)$ occupancy factors. For population dose

calculation, (IADD $=0$ ) only need input values for $i=1$.

OCUPF (1,1): Average fraction of population indoor.

Default: 0.5 .

OCUPF(1,2): Average fraction of population outdoor.

Default: 0.25 .

PLNK Population density on-link (persons/km):

If -1 , use code-provided value.

Default: -1 .

POPD Pupulation density between distances, $\mathrm{XPZ}(1)$ and $\mathrm{XPZ(2)}$ (persons/ $\mathrm{km}^{2}$ ).

Default: 2.

PIVH Average number of persons in each vehicle for population on-link.

Default: 2,5,5.

PSTP(10) Number of persons exposed in each stop type.

Default: $10 * 50$.

RDWTH Road width (m):

if -1 , use code-provided value.

Default: -1 .

RFIE Fraction of population indoor during accident.

Default: $\mathbf{0 . 5 8 3 .}$

XING(3) Average individual food consumption rate $(\mathrm{kg} / \mathrm{d})$ for population dose calculation:

Defaults:

$\mathrm{i}=1$, meat $\quad \mathrm{XING}(1)=0.26$.

$\mathrm{i}=2$, milk $\mathrm{XING}(2)=0.33$.

$\mathrm{i}=3$, vegetation $\mathrm{XING}(3)=0.28$. 
TABLE G.1 (Cont.)

Input

Parameter

Description

XPZ(2) Population zone downwind distances $(\mathrm{km})$ of in orest.

$\mathrm{XPZ}(1)$ : minimum distance.

Default: 0.05 .

$\mathrm{XPZ}(2)$ : maximum distance.

Default: 80.

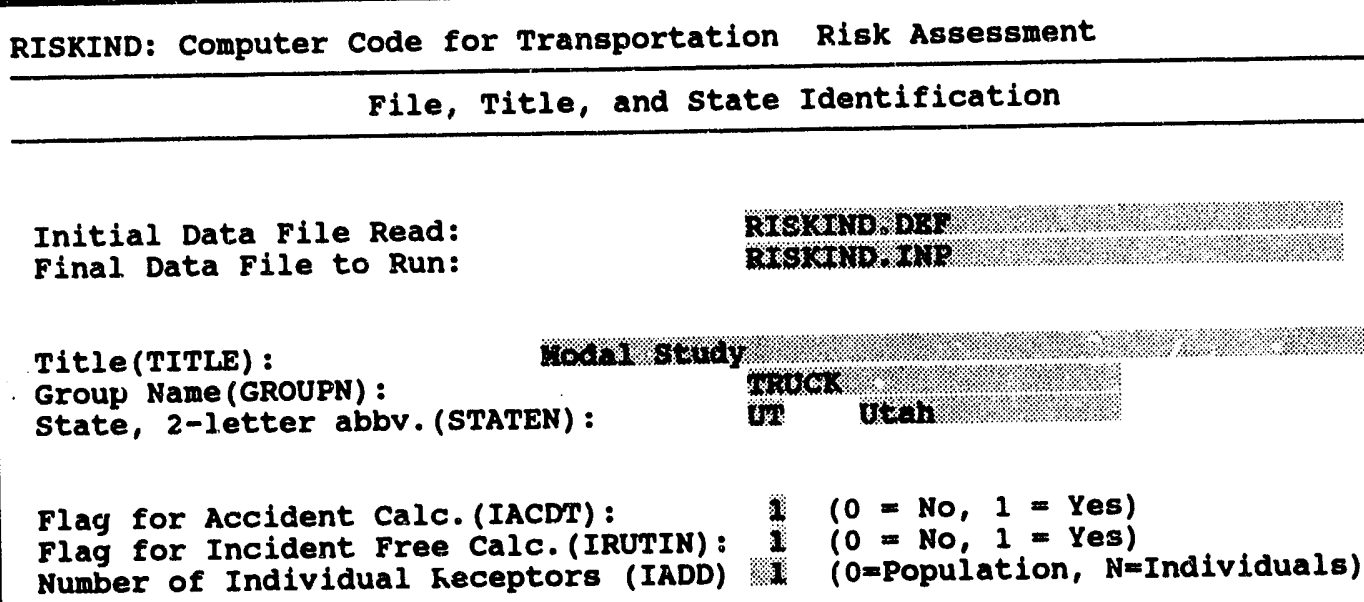

Initial Data File Read:

Final Data File to Run:

Title (TITLE) :

Group Name (GROUPN) :

state, 2-letter abbv. (STATEN):

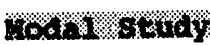

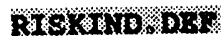

BXsXID ONI?

Flag for Accident Calc. (IACDT):

Flag for Incident Free Calc. (IRUTIN): $1 \quad(0=$ No, $1=$ Yes)

Number of Individual Keceptors (IADD) / ( $0=$ Population, $N=$ Individuals)

Press "F1" or "F2" for HELP, or "Esc" to IGNORE CHANGES and return to main menu. Press "FIO" to SAVE DATA AND CONTINUEe

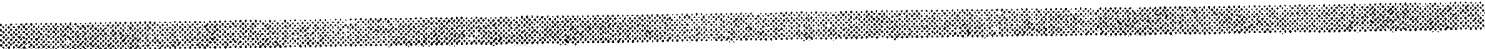

FIGURE G.2 Input Screen of RIE: System, Category 1 
RISKIND: Computer Code for Transportation Risk Assessment

(M012)

Spent Fuel Source Term and Cask Information

Reactor TYpe (RTYPE):

Fuel Burnup (BURNUP):

Spent Fuel cooling Time TFUEL):

Label for type of cask (TYPCSK):

Cask shipping Capacity (UNT):

Radius of spent Fuel Cask (RSIZE) :

Length of Cask (HSIZE):

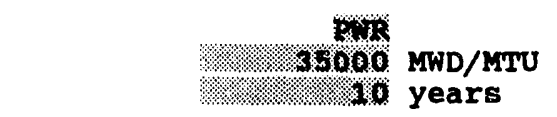

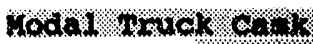

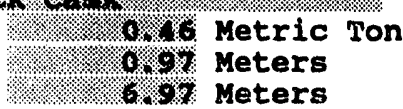

Transport Index (mrem/hr) at 1 meter from cask surface (TIDX):

Transport Index contributed by Gamma Radiation (FRAD(1)):

Transport Index Contributed by Neutron Radiation (FRAD(2)):

CRUD Information (Enter if IACDT $=1$ ): :

Crud Activity Surface Density of Cask (CACTD):

Total Surface Area of Cask Cavity (CAREA):

Volume of void in cask (CVOID):

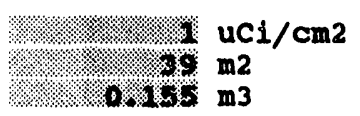

Press "FI" or "F2" for HELF, or "Esc" to IGNORE CHANGES and return to main menu. Press "FIO" to SAVE DATA AND CONTINUE.

\%.

FIGURE G.3 Input Screen of RISKIND System, Category 2

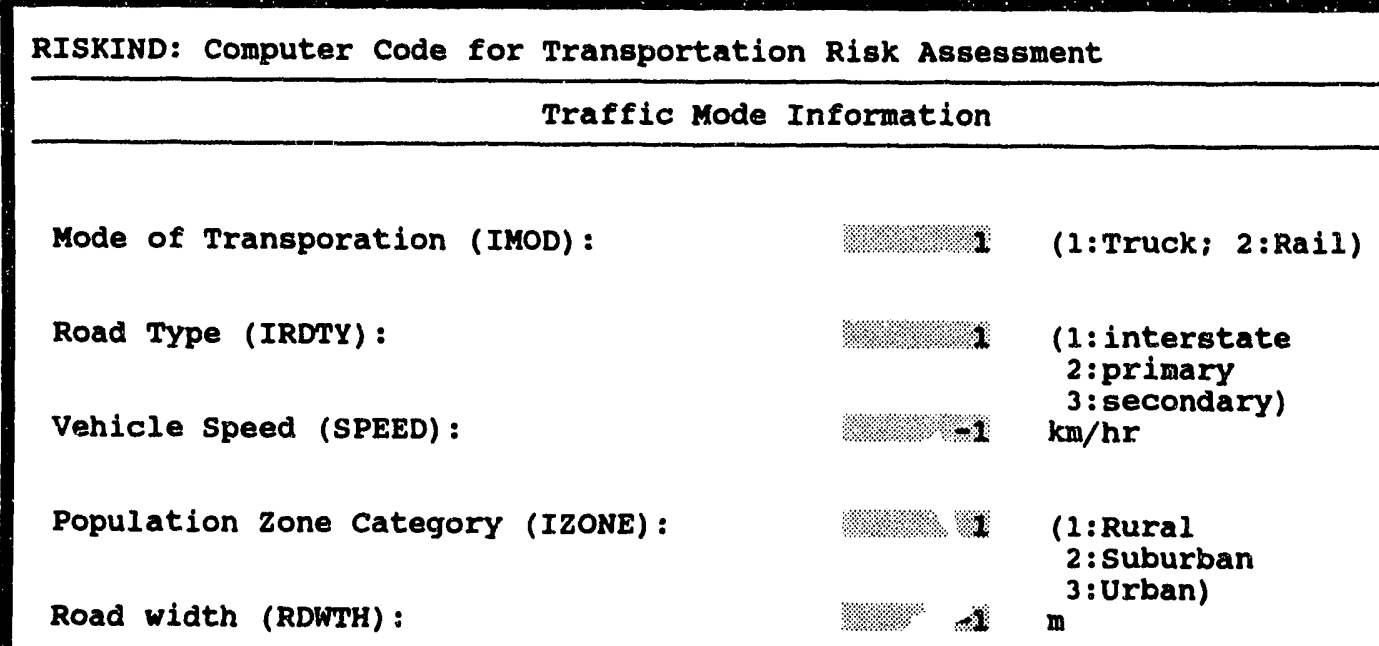

Press "FI" or "F2" for HELP, or "Esc" to IGNORE CHANGES and return to main menu. Press "F10" to SAVE DATA AND CONTINUE.

\%:.

FIGURE G.4 Input Screen of RISKIND System, Category 3 
RISKIND: Computer Code for Transportation Risk Assessment

(M014)

Accident Probability and Release Data (IACDT=1)

Accident Probability (ACTA):

Unit of Probability for ACTA (PBUNIT)

Physical Release Height (HS):

Ground Contamination Cleanup Dose Criterion(PAG) :

Hazard Limit for Selecting Radionuclides (HZLM):

Flag for Level of Conservatism in Health Risk Calc. (IBOUND):

Flag for Level of Medical Treatments (ITREAT):

Initial Resuspension Factor (SUFI):

Final Resuspension Factor, (SUFF):

Number of Years for Calculating Dose commitment (YEVD):

Flag for accident scenario input (IYOURS):

$(-1$ : input your own accident parameters;

0 : use all NRC Model Study response regions;

$i$ : use ith NRC Model study response region)

"FI" for HELP, "Esc" to IGNORE CHANGES, "FIO" to SAVE DATA AND CONTINUE

I.:.

FIGURE G.5 Main Input Screen of RISKIND System, Category 4

RISKIND: Computer Modules for Spent Fuel Transport Risk Assessment

(M014b)

Accidental external dose multiplication factor due to loss

of shielding, expressed in multiples of TI (SEXT):

( IACDT $=1$ )

\begin{tabular}{|c|c|c|c|c|c|c|c|c|c|c|}
\hline $\begin{array}{l}\text { Accident } \\
\text { Response } \\
\text { Region }\end{array}$ & 1 & 2 & 3 & 4 & 5 & 6 & 7 & 8 & 9 & 10 \\
\hline $\begin{array}{l}\text { Gamma } \\
\text { Neutron }\end{array}$ & 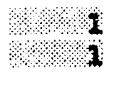 & $\begin{array}{lll}8 & 1 \\
3 & 1 \\
& 1\end{array}$ & ?: & . 1.1 & 9.1 & 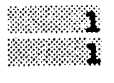 & $\begin{array}{l}7 \\
7.1 \\
8\end{array}$ & 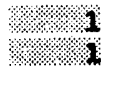 & ?.7. & ;: \\
\hline $\begin{array}{l}\text { Accident } \\
\text { Response } \\
\text { Region }\end{array}$ & 11 & 12 & 13 & 14 & 15 & 16 & 17 & 18 & 19 & 20 \\
\hline $\begin{array}{l}\text { Gamma } \\
\text { Neutron }\end{array}$ & 17.9 & 1.7. & \%: & \% 19 & 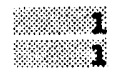 & \% & ?: & \%. & /. & ?: \\
\hline
\end{tabular}

Press "F1" or "F2" for HELP, or "Esc" to IGNORE CHANGES and return to main menu.

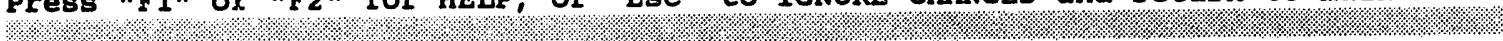

FIGURE G.6 Additional Input Screen of RISKIND System, Category 4 
RISKIND: Computer Code for Transportation Risk Assessment

(M014s)

Accident Scenario Input Parameters (IXOURS $=-1$ )

Cask Velocity $(0-150)$ (VCASK):

Flame Temperature $(1400-24000)$ (TFLAME):

Fire Duration $(0-8)$ (DFIRE):

Fire Location (truck:0 - 30, rail: 0 - 43) (FLOCA):

Impact Angle measured in degrees $(0-90)$ (ALPHA) :
Cask orientation Angle measured in degrees $(0-90)$ (BETA): $: .1 .90$.

object Hardness Index (IHARD) :

1 - unyielding, 2 - medium, 3 - soft, 4 - very soft
40. miles/hr

Woo: degree $\mathbf{F}$

5. hrs

0. $f t$

1

Press "F1" or "F2" for HELP, or "Esc" to IGNORE CHANGES and return to main menu. press "F10" to SAVE DATA AND CONTINUE.

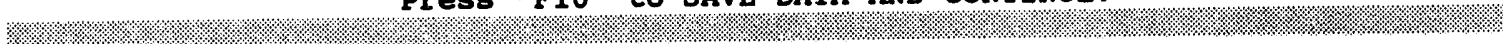

FIGURE G.7 Input Screen of RISKIND System, Category 4 for User-Defined Scenario

RISKIND: Computer Code for Transportation Risk Assessment

(M015)

Meteorological Data and Dispersion Calculational Parameters (IACDT=1)

Anameter Height (ANH):

Ambient Temperature (TABK):

$\% .10 \mathrm{~m}$

Ground depostion velocity of particulates (VDEP):

08:8: $\quad K$

Farmland depostion velocity of particulates (VDVEG):

\%.:001 $\mathrm{m} / \mathrm{s}$

Water surface deposition Velocity (WDEP):

\%.:. $0.0 \mathrm{~m} \mathrm{~m} / \mathbf{s}$

Water surface deposition Velocity (WDEP):

\%:.:02: $\mathbf{m} / \mathbf{s}$

Meteorological Input Data Option (IYOURW) :

1: Input your own wind speed and stability

0 : User wind Frequency data set

"F1" or "F2" for HELP, "ESC" to IGNORE CHANGES, "Fio" to SAVE DATA AND CONTINUE

\%1.

FIGURE G.8 Input Screen of RISKIND System, Category 5 
RISKIND: Computer Code for Transportation Risk Assessment

(M0151)

Meteorological Data and Dispersion Calculational Parameters (IYOURW:1)

This screen is for entering a specific weather profile

Mixing Height (DKIX):

\%: $600 \mathrm{~m}$

Pasquill atmospheric stability category (ITYPE):

\%

Rain fall rate (RAIN):

20.0 $\mathrm{mm} / \mathrm{hr}$

Wind Speed measured at anemometer height (WSM):

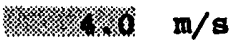

"F1" for HELP, "Esc" to IGNORE CHANGES, "F10" to SAVE DATA AND CONTINUE

\% \%

FIGURE G.9 Additional Input Screen of RISKIND System, Category 5

RISKIND: Computer Code for Transportation Risk Assessment

(M0150)

Meteorological Data and Dispersion Calculational Parameters

(IYOURW $=0)$

Morning Mixing height (AMIX):

\%.1.0. $\mathrm{sm}$

Afternoon Mixing Height (PMIX):

\% $2000 \mathrm{~m}$

Input option of wind frequency data (IMET)

o.

Percent (0)/ Fraction (1) flag (IFREQ):

1

Average wind speed for the 6 wind categories (WS):

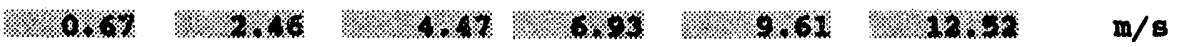

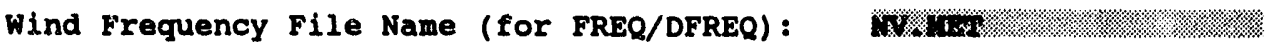

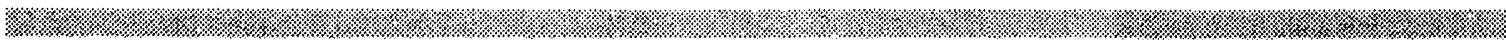

FIGURE G.10 Additional Input Screen of RISKIND System, Category 5 


\begin{tabular}{|c|c|c|c|c|c|c|}
\hline RISKIND: & IND: Computer M & dules for & Spent Fuel & Transport & sk Asses: & (M015B) \\
\hline \multirow[t]{2}{*}{ wind } & \multicolumn{6}{|c|}{$\begin{array}{l}\text { Frequencies (Wind Speed vs. Pasquill-Gifford Stability Class } \\
\text { (IYOURW }=0 \text {, and IMET }=1 \text { ) }\end{array}$} \\
\hline & 1 & 2 & 3 & 4 & 5 & 6 \\
\hline \multirow{3}{*}{$\begin{array}{l}\text { W } \\
\text { I } \\
\text { N } \\
\text { D }\end{array}$} & $\% .0278$ & \%. & $1 \% .10278$ & \% & $\% . / 02 / 28$ & /. \\
\hline & $\% .0200$ & \%: & $1.10 .027 \mathrm{a}$ & \% & $1 \% 1.0828 \mathrm{R}$ & \% / . . \\
\hline & \%. & . & 1.0278 & 1.0278 & $1.1 .0 \mathrm{mo}$ & \% \\
\hline \multirow{4}{*}{$\begin{array}{l}\text { S } \\
\mathbf{P} \\
\mathbf{E} \\
\mathbf{E} \\
\mathbf{D}\end{array}$} & : $: 19.0210$ & $1 \%, 0276$ & $\% .0278$ & \%. .02726 & \%. .0228 & / \\
\hline & & & & & & \\
\hline & /. & (1/. & .1 .10278 & $.1 .002 \pi \mathrm{a}$ & (1) & \% \\
\hline & \% & \% & $1 . .027 \mathrm{a}$ & $1.1002 \pi$ & \% & \% \\
\hline \multicolumn{7}{|c|}{ NOTE: No wind Direction Dependency for DFREQ } \\
\hline \multicolumn{7}{|c|}{ Press "FIo" to SAVE DATA AND CONTINUE } \\
\hline
\end{tabular}

FIGURE G.11 Additional Input Screen of RISKIND System, Category 5

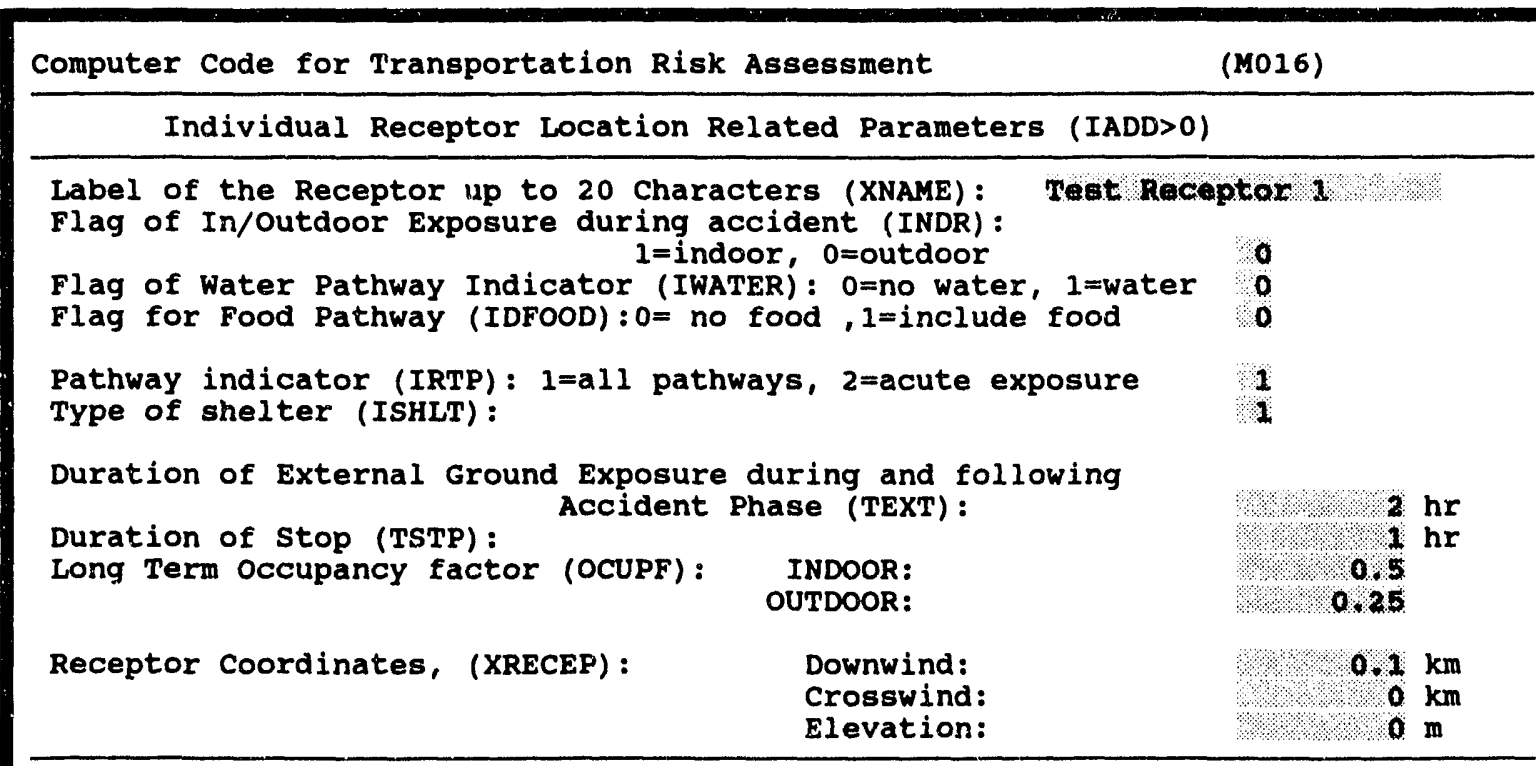

Press "F5" to go to next receptor: "F6" to go to previous receptor

Pr.

FIGURE G.12 Input Screen of RISKIND System, Category 6 
Computer Code for Transportation Risk Assessment

(M016B)

Population Water Body Location Related Parameters (IPWATR>0)

Label of the Receptor up to 20 Characters (XNAME): Defrault Natox Body 1 .

Receptor Coordinates, (XRECEP): Downwind: $\quad$ Crosswd:

Crosswind:

Elevation:

Number of People consuming water (POPW):

:. $.1 .1 \%$

Mixing Depth of Contaminated Water Body (WBDYD):

2. $0 \mathrm{~m}$

Water body exchange rate (WEXCG):

1

Cross wind width of Contaminated Water Body (WBDYW) :

Press "F5" to go to next receptor; "F6" to go to previous receptor

"Fl" for HELP, "Esc" to IGNORE Changes, "Fio" to save DATA AND CONTINUE

"1.

FIGURE G.13 Additional Input Screen of RISKIND System, Category 6

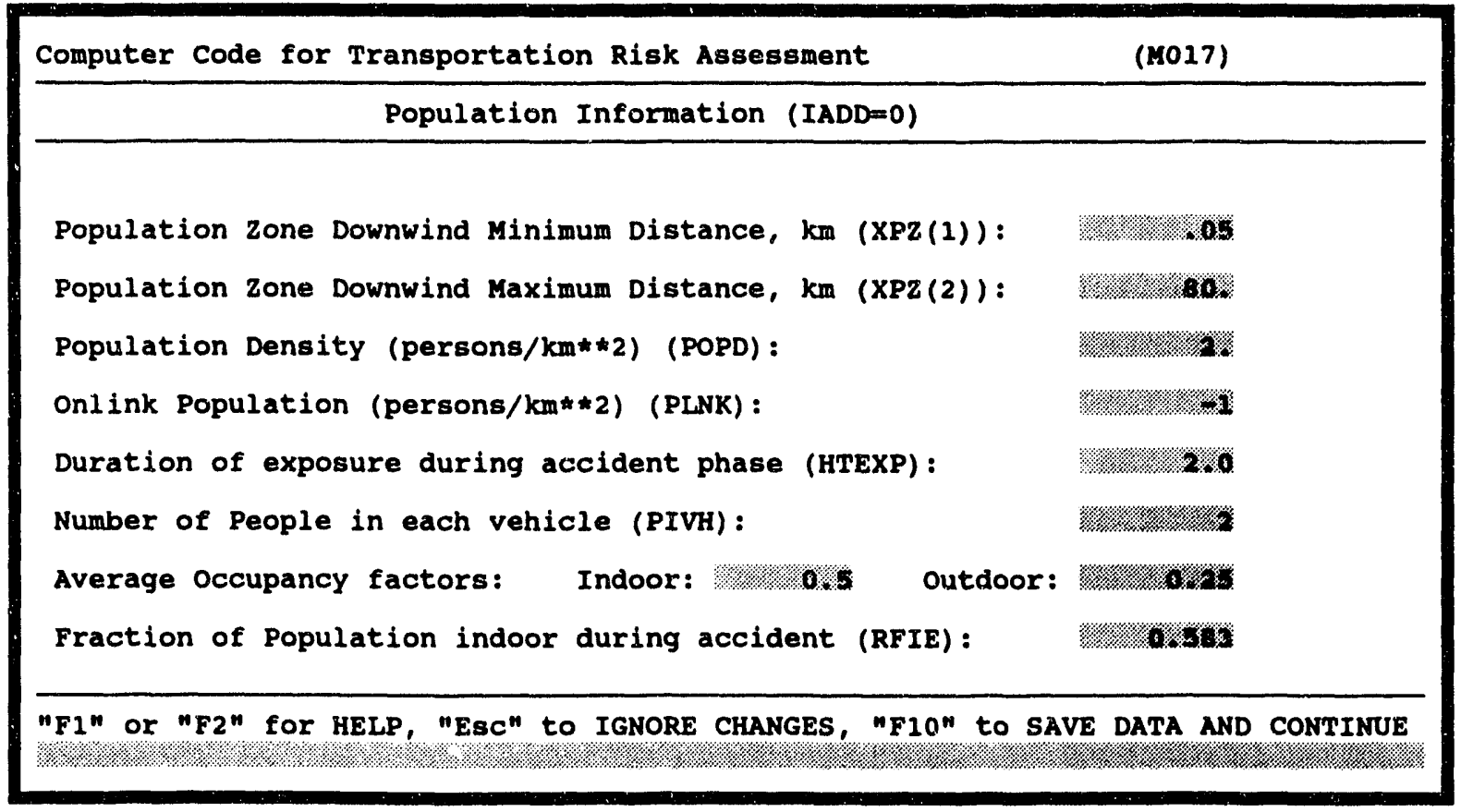

FIGURE G.14 Input Screen of RISKIND System, Category 7 


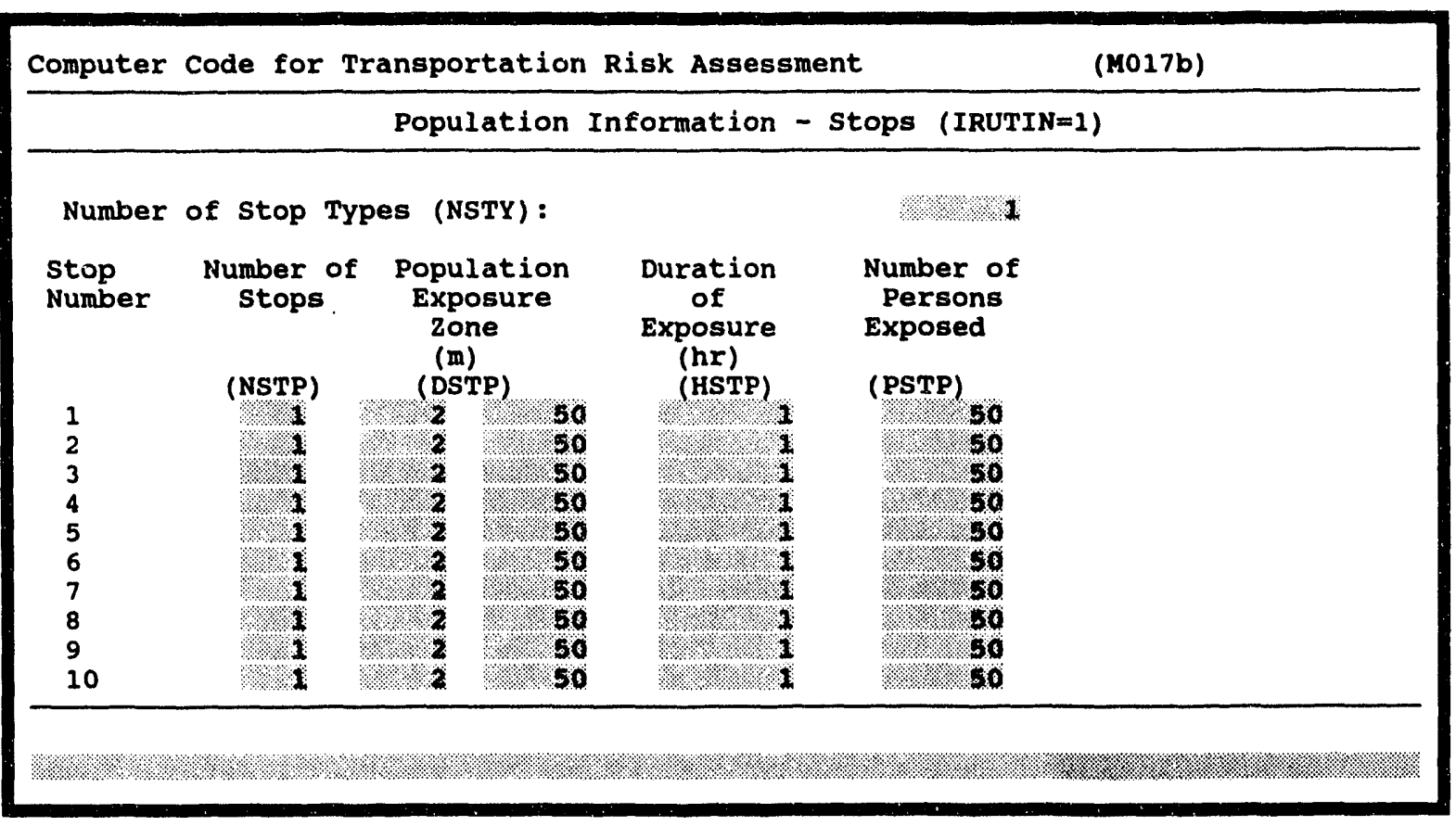

FIGURE G.15 Additional Input Screen of RISKIND System, Category 7

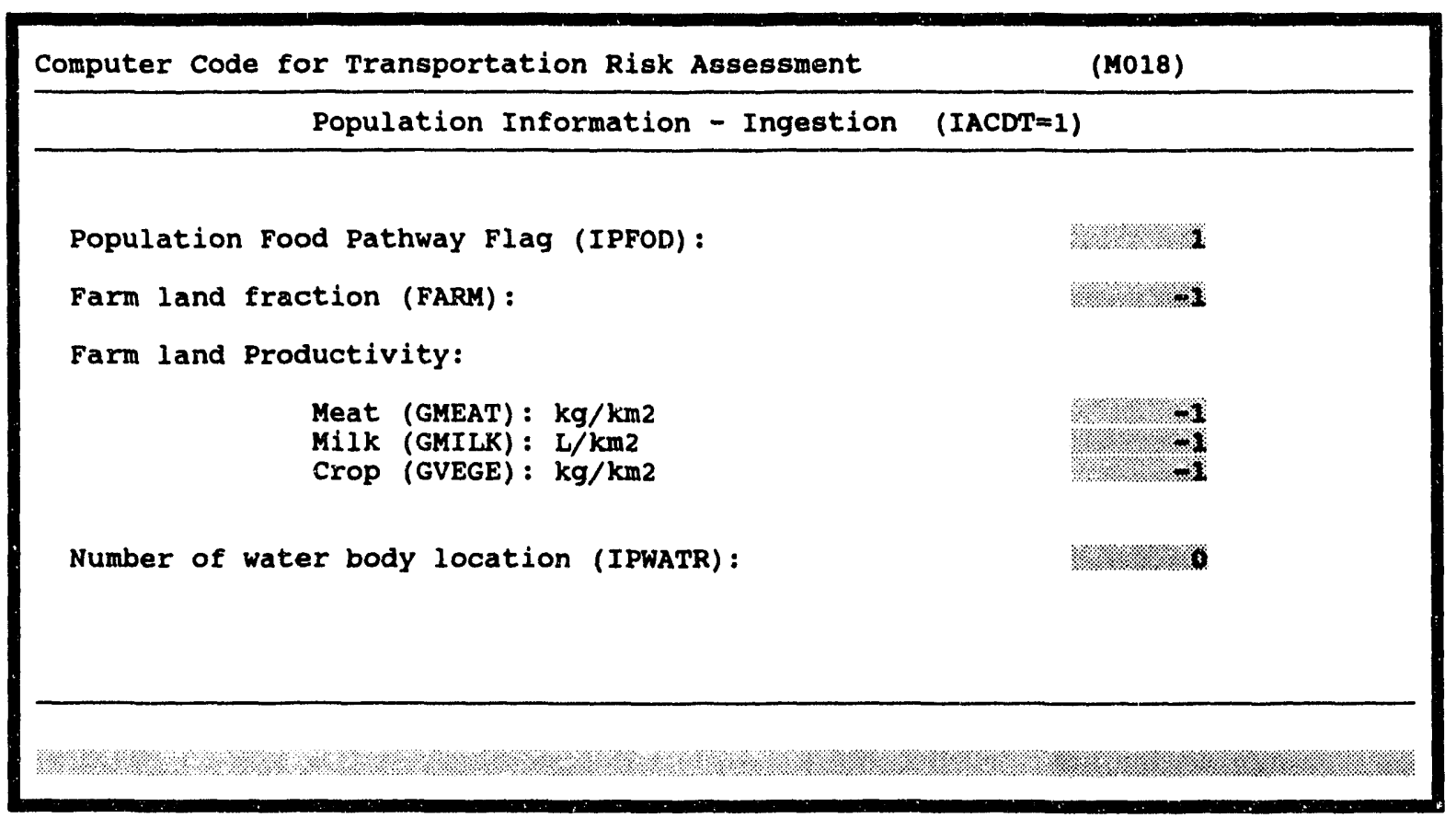

FIGURE G.16 Input Screen of RISKIND System, Category 8 
RISKIND: Computer Code for Transportation Risk Assessment

Long Term Exposure Data (IACDT=1)

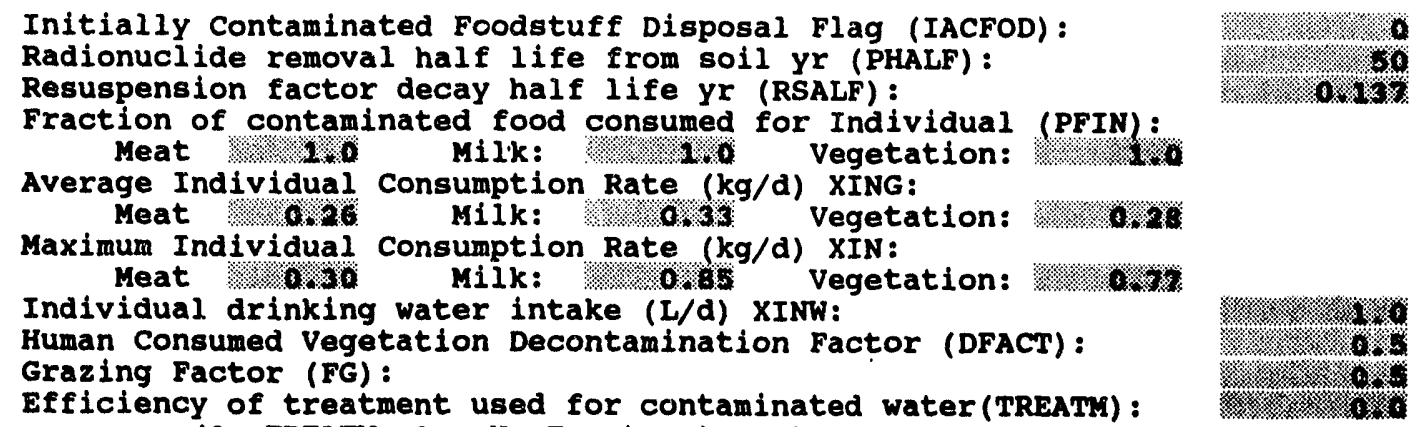

Efficiency of treatment used for contaminated water(TREATM): $(0<=$ TREATM $<=1$; No Treatment $=0)$

Press "F1" or "F2" for HELP, or "Esc" to IGNORE CHANGES and return to main menu. Press "FIO" to SAVE DATA AND CONTINUE.

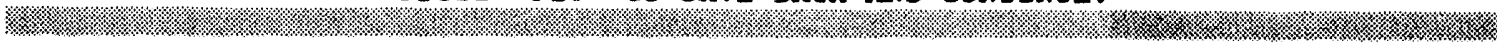

FIGURE G.17 Input Screen of RISKIND System, Category 9

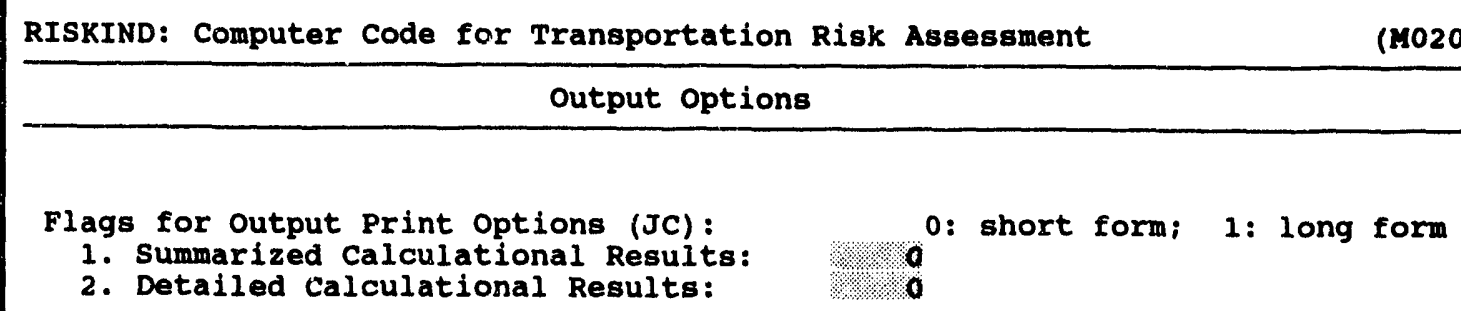

If IACDT=1 Input the Following:

Graphic output File Name (NGRF):

Graphic Output Heading (HEADING):

Output File Name (OUTFIL): 
APPENDIX H:

SAMPLE PROBLEMS 


\section{APPENDIX H: \\ SAMPLE PROBLEMS}

The use of RISKIND is illustrated in this appendix through two sample problems. A sample problem for incident-free dose calculation is presented in Sections H.1 through H.3. A sample problem for dose calculation under accident conditions is presented in Sections H.4 through H.6. In both problems, four receptor descriptions are used to indicate the locations of individuals: nearest resident $(50 \mathrm{~m})$, nearest gas station $(30 \mathrm{~m})$, nearest school $(150 \mathrm{~m})$, and nearest shopping mall $(100 \mathrm{~m})$. Descriptions of the input parameters used in RISKIND are provided in Appendix G.

\section{H.1 SAMPLE PROBLEM ONE: INCIDENT-FREE CONDITIONS}

The first sample problem considers incident-free transportation of spent nuclear fuel along an interstate highway in Maryland. The four receptor locations are those described above. The sample problem input list is given in Section H.2. The shipping cask is assumed to be a GA-4 truck cask, and the spent fuel is assumed to be 10 years old, with a transport index (TI) of 14 . The radiation field is $83 \%$ gamma and $17 \%$ neutron in dose. Two modes of exposure are evaluated: one is for a stop with an exposure time of one hour, and the other is for a passing truck.

The sample problem output list is given in Section H.3. The output reflects the input parameters and represents the calculated doses for the four receptors for the two modes of exposure. 
H.2 INPUT DATA FOR SAMPLE PROBLEM ONE: INCIDENT-FREE CONDITIONS

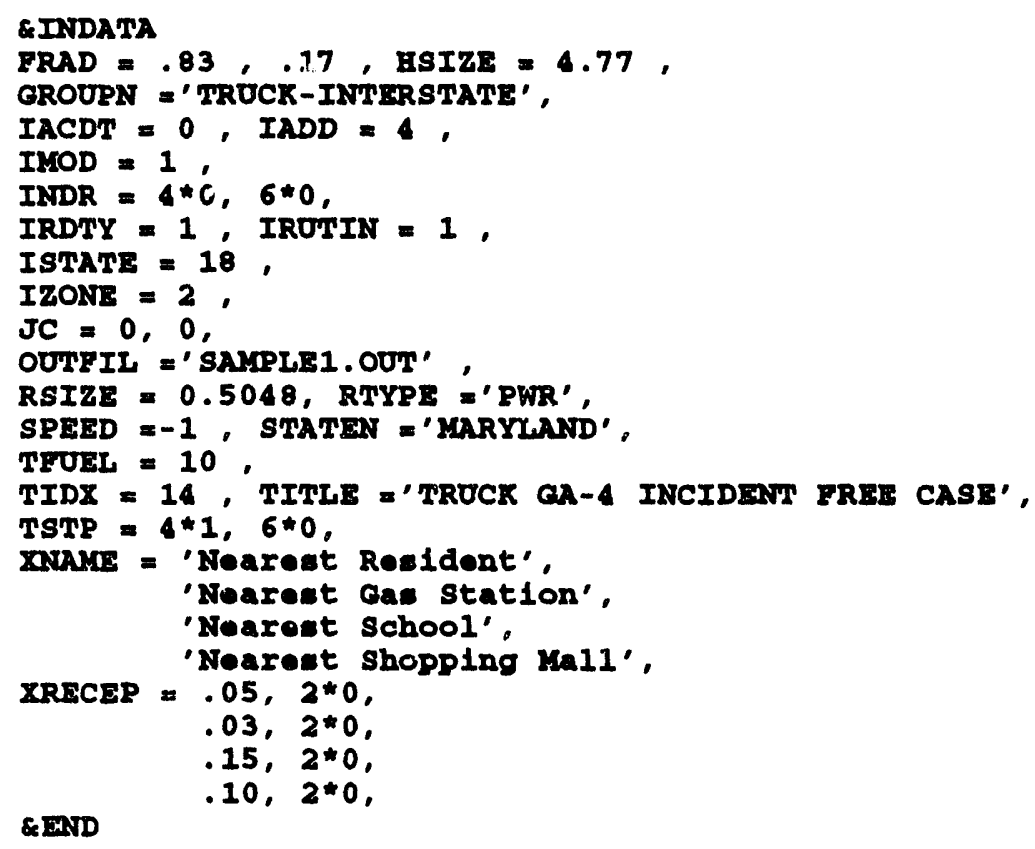




\section{H.3 OUTPUT DATA FOR SAMPLE PROBLEM ONE: INCIDENT-FREE CONDITIONS}

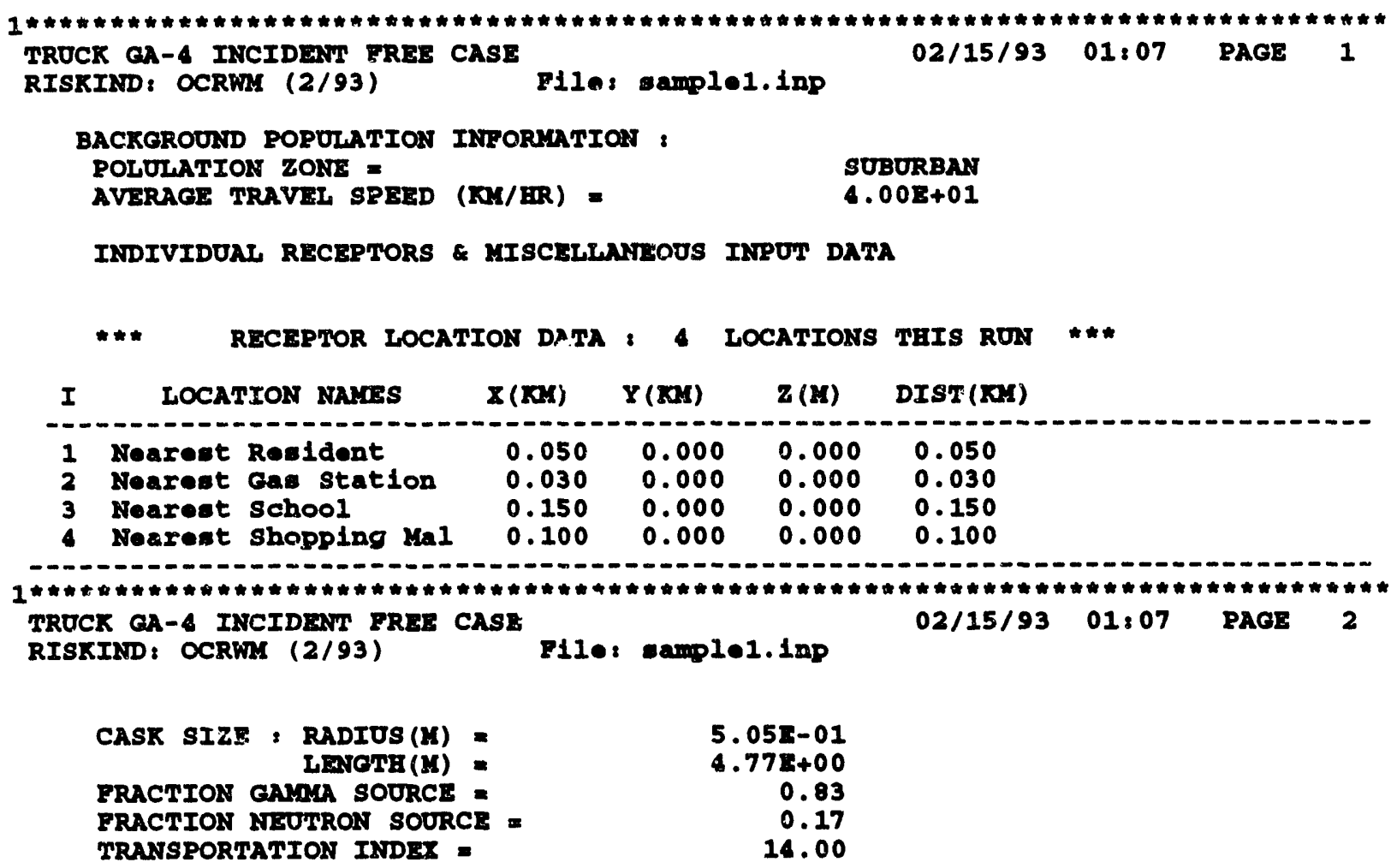

RECEPTOR ROUTINE DOSE EROY EACE SEIPLANT

\begin{tabular}{|c|c|c|c|c|c|}
\hline$T$ & LOCATION NAMES & DISTANCE (K) & BOUR & $\sin _{10}$ & $\begin{array}{l}\text { DURING } \\
\text { TRANSPORT } \\
---- \\
\text { REM }\end{array}$ \\
\hline $\begin{array}{l}1 \\
2 \\
3 \\
4\end{array}$ & $\begin{array}{l}\text { Nearest Resident } \\
\text { Neareet Gas station } \\
\text { Nearest School } \\
\text { Nearest Shopping Mal }\end{array}$ & $\begin{array}{r}50.0 \\
30.0 \\
150.0 \\
100.0\end{array}$ & $\begin{array}{l}1.0 \\
1.0 \\
1.0 \\
1.0\end{array}$ & $\begin{array}{l}2.15=-05 \\
6.55 z-05 \\
1.38 z-06 \\
1.078-06\end{array}$ & $\begin{array}{l}6.27 \mathrm{E}-08 \\
1.28 \mathrm{E}-07 \\
1.02 \mathrm{E}-08 \\
2.15 \mathrm{E}-08\end{array}$ \\
\hline
\end{tabular}




\section{H.4 SAMPLE PROBLEM TWO: ACCIDENT CONDITIONS}

The second sample problem considers accident conditions during transport. The four receptor locations are the same as those in the first sample problem. The sample problem input list is given in Section H.5. In this problem, individual doses (consequences) are to be calculated from accident conditions. The spent fuel is assumed to be pressurized-water reactor (PWR) fuel, with a burnup of 33,000 megawatt-days per metric ton of initial heavy metal (MWd/MTIHM) and a 10-year cooling period. Only short-term exposures from plume passage (ITRP=2) are assumed.

The sample problem output list is given in Section H.6; this output also includes the input parameters and calculated doses for the four receptors. The accident probability is 1.0 because the consequences, not the risk, are calculated. Following the input data is a list of radionuciides that have been screened and selected according to their importance (radiological hazard) and total inventory (in curies) in the cask. This information is followed by the release fractions, as specified in the modal study of the U.S. Nuclear Regulatory Commission (Lawrence Livermore National Laboratory [LLNL] 1987), and the actual release amount in curies, corresponding to the 20 cask response regions.

The consequences are then presented for each of the 20 cask response regions for which the input accident conditions are repeated. A summary of the calculated consequences for the 50-year committed effective dose equivalent and the probability of early fatalities is also presented. This information is repeated for the 20 cask response regions. The last output item is the total summary of the individual risks weighted by the conditional accident probabilities over the 20 cask response regions. Figure H.1 shows the dose versus accident conditional probabilities for the four receptor locations; all dose values in the figures are calculated on the basis of the reasonably worse meteorological conditions or $95 \%$ probability weather conditions. 


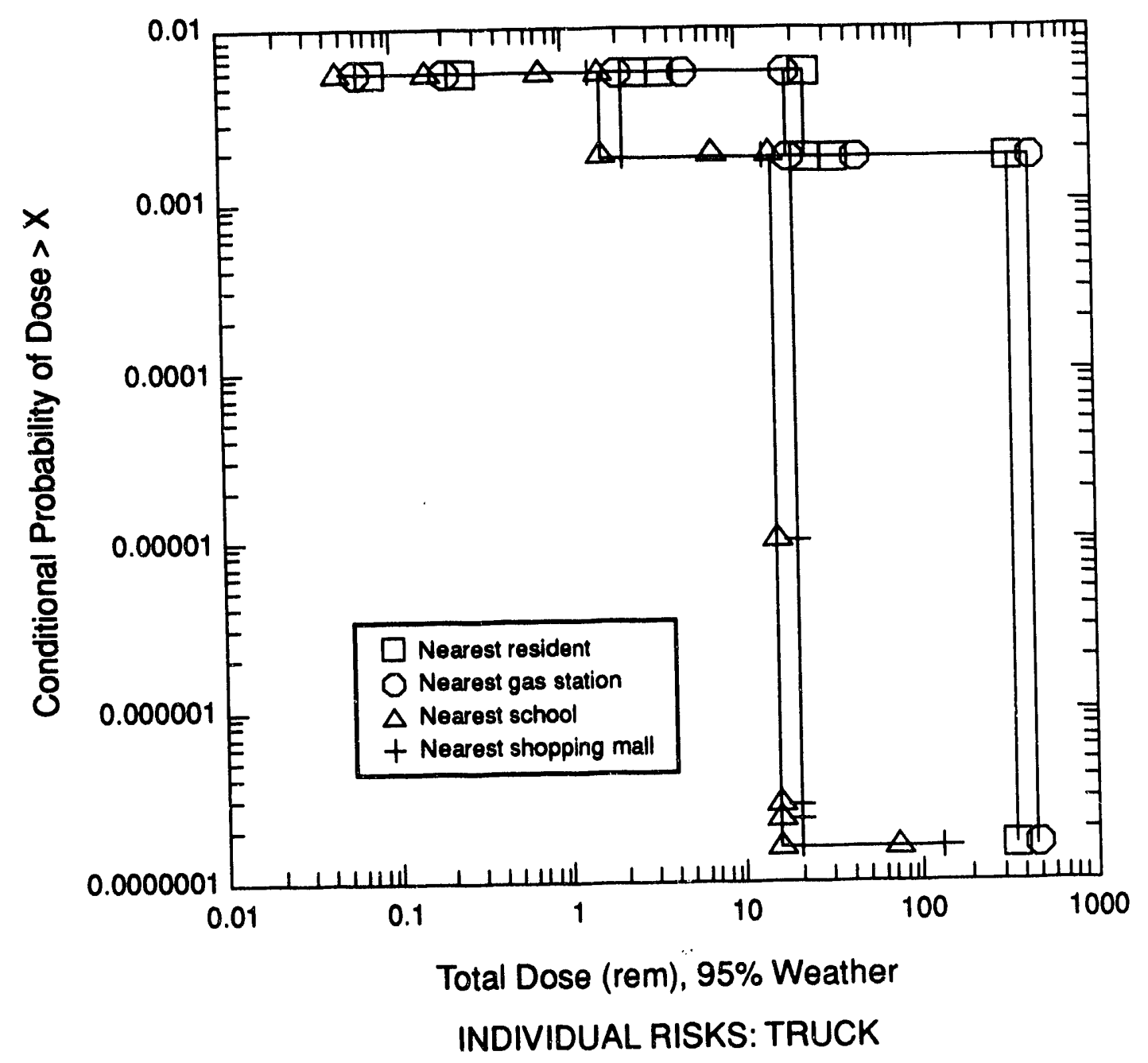

FIGURE H.1 Individual Doses versus Conditional Accident Probabilities 


\section{H.5 INPUT DATA FOR SAMPLE PROBLEM TWO: ACCIDENT CONDITIONS}

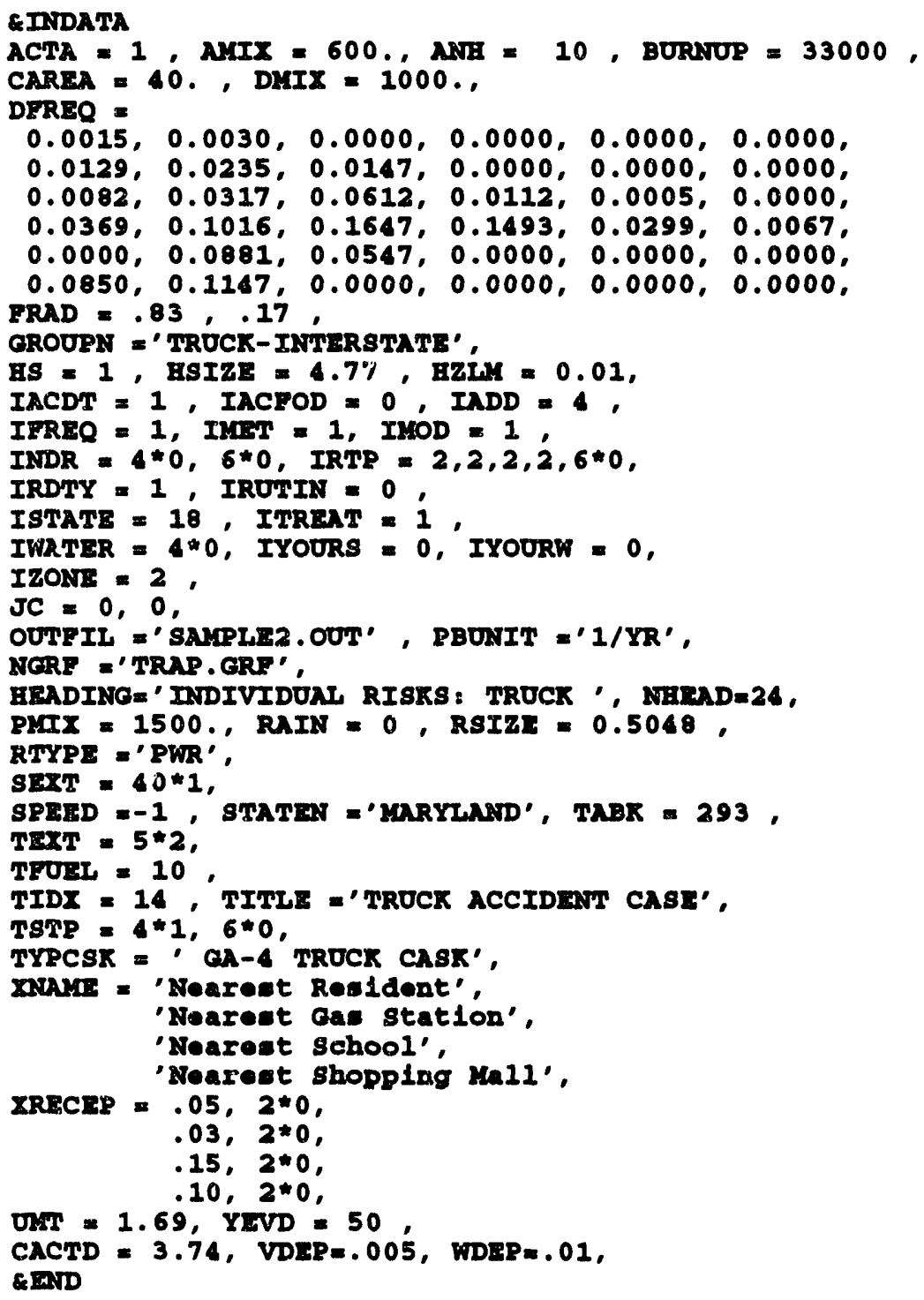




\section{H.6 OUTPUT DATA FOR SAMPLE PROBLEM TWO: ACCIDENT CONDITIONS}

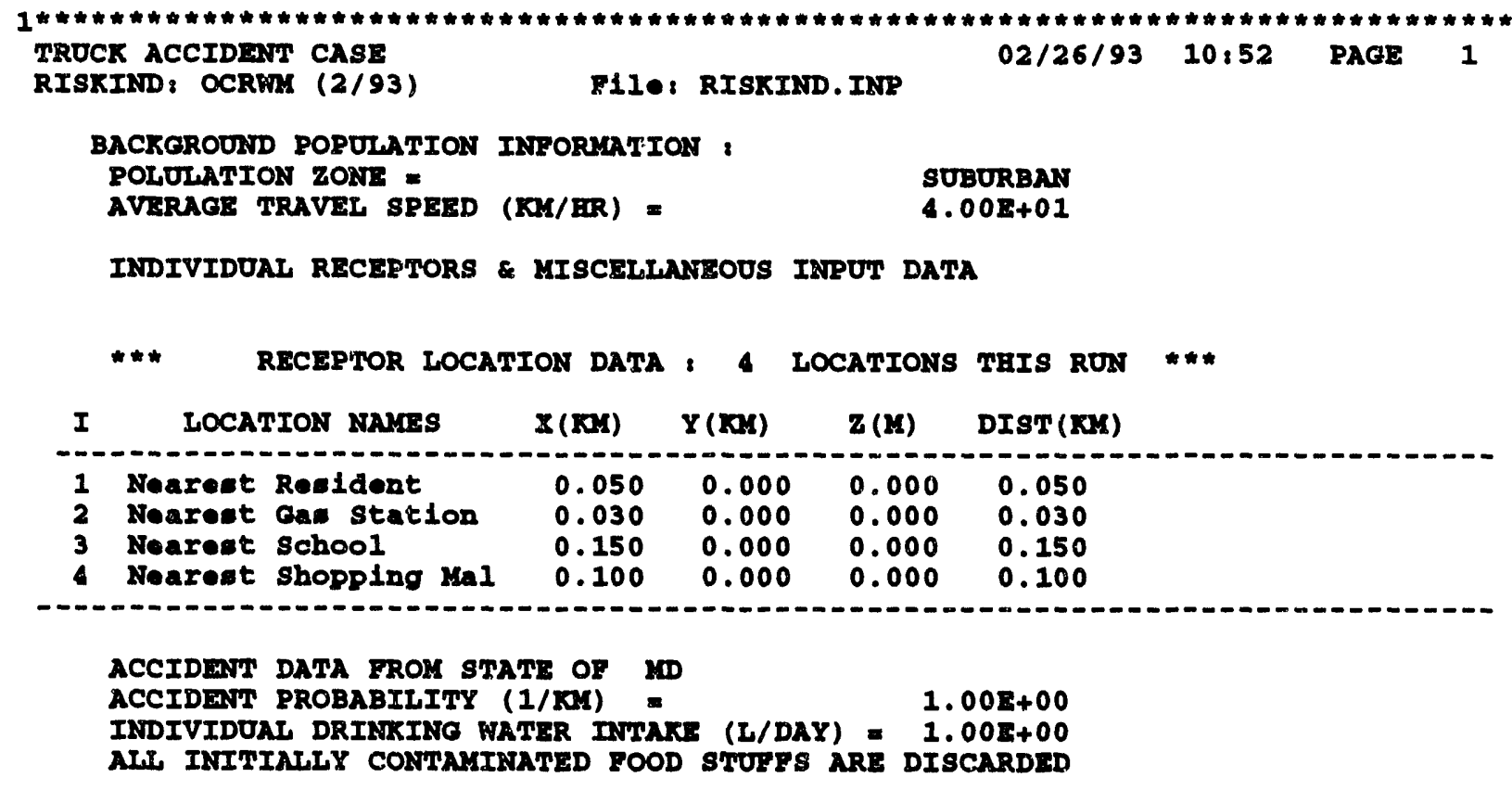

ANNUAL FREQUENCE OF OCCURENCE -- SUR OF ALL WIND DIRECTIONS SREED, $\quad \mathrm{K} / \mathrm{S}$

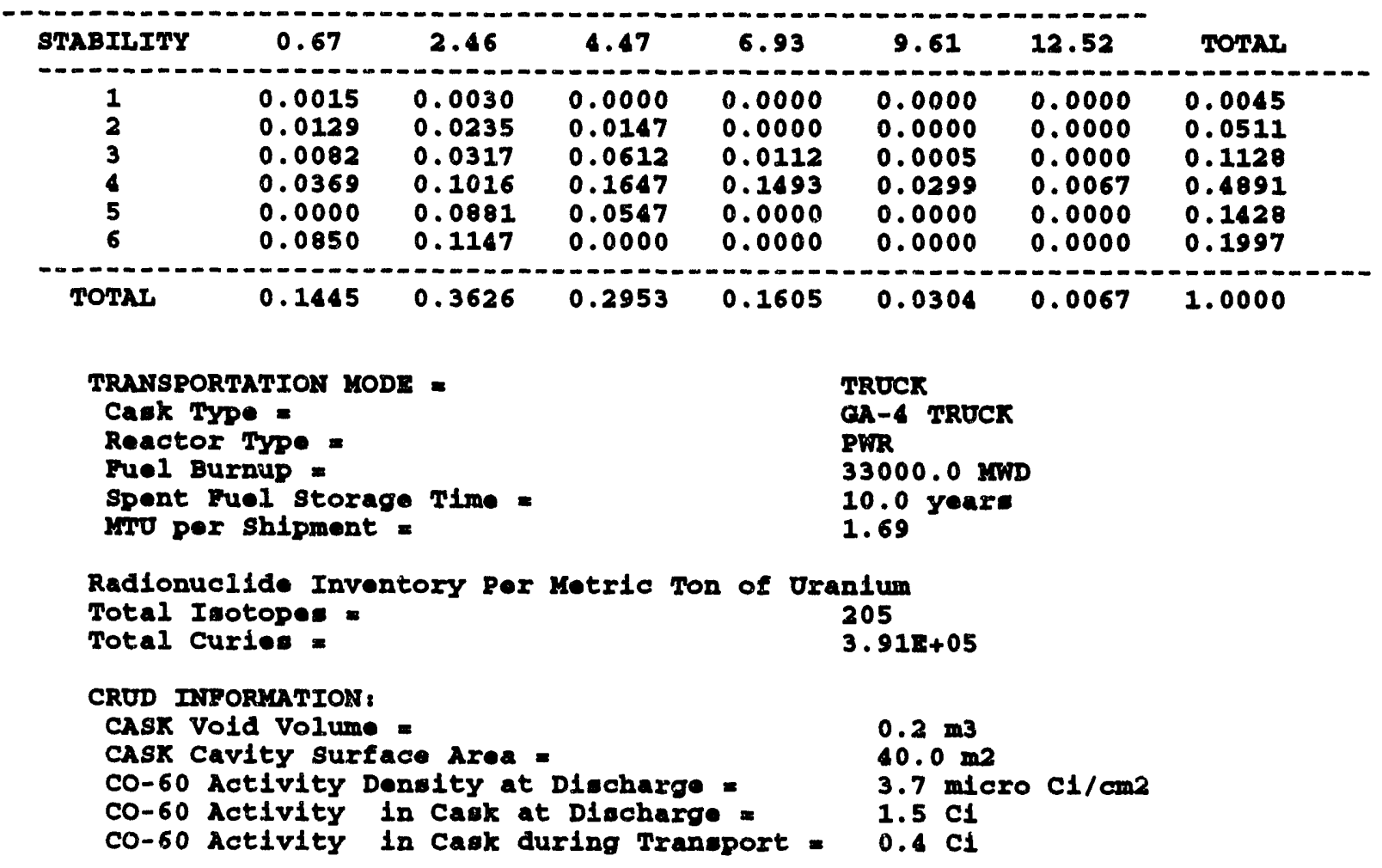




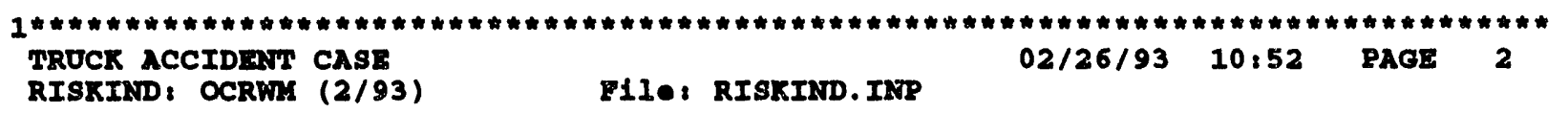

ERACTION RELEASED AND ALSO DISPERSED FOR EACE RESPONSE REGION

\begin{tabular}{|c|c|c|c|c|c|c|c|c|c|c|}
\hline \multirow{2}{*}{$\begin{array}{l}\text { NOCLID } \\
\text { TYPE }\end{array}$} & \multicolumn{10}{|c|}{ RESPONSE RECION } \\
\hline & 1 & 2 & 3 & 4 & 5 & 6 & 7 & 8 & 9 & 10 \\
\hline $\begin{array}{l}\text { PART. } \\
\text { RU } \\
\text { CS } \\
\text { IODINI } \\
\text { CAS } \\
\text { CROD }\end{array}$ & $\begin{array}{l}0 . E+00 \\
0 . E+00 \\
0 . z+00 \\
0 . E+00 \\
0 . E+00 \\
0 . E+00\end{array}$ & $\begin{array}{l}2 . z-07 \\
3 . z-06 \\
2.5-05 \\
3.5-04 \\
3.5-02 \\
1 . E+00\end{array}$ & $\begin{array}{l}2.5-06 \\
3.5-05 \\
2.5-04 \\
2.5-03 \\
3.5-01 \\
1.5+00\end{array}$ & $\begin{array}{r}2 . z-05 \\
3 . E-04 \\
2.8-03 \\
. . E-02 \\
6.5-01 \\
1.8+00\end{array}$ & $\begin{array}{l}6.5-08 \\
8.5-07 \\
6.5-06 \\
7.5-05 \\
1.5-02 \\
2.8-01\end{array}$ & $\begin{array}{l}2.5-07 \\
3 . \mathrm{z}-06 \\
2.5-05 \\
3.5-04 \\
3.5-02 \\
1.5+00\end{array}$ & $\begin{array}{l}2.5-06 \\
3.5-05 \\
2.5-04 \\
2.5-03 \\
3.5-01 \\
1.5+00\end{array}$ & $\begin{array}{l}2 \cdot z-05 \\
3.5-04 \\
2 . z-03 \\
1 . E-02 \\
6 . z-01 \\
1 . z+00\end{array}$ & $\begin{array}{l}6 . \mathrm{E}-08 \\
8 . \mathrm{E}-07 \\
6 . \mathrm{E}-06 \\
7 . \mathrm{E}-05 \\
1 . \mathrm{E}-02 \\
2 . \mathrm{E}-01\end{array}$ & $\begin{array}{l}2 . \mathrm{E}-07 \\
3 . \mathrm{E}-06 \\
2 . \mathrm{E}-05 \\
3 . \mathrm{E}-04 \\
3 . \mathrm{E}-02 \\
1 . \mathrm{E}+00\end{array}$ \\
\hline PROB & $1.8+00$ & $4.5-03$ & $2 \cdot \mathrm{s}-03$ & $2 \cdot 5-07$ & $2.5-05$ & 2. $.5-07$ & 2. $:-07$ & $4.5-14$ & 2. $\mathrm{B}-05$ & $3 \cdot$ E-07 \\
\hline
\end{tabular}

ERACTION RELEASED NW ALSO DISPERSED FOR EACE RESPONSE REGION

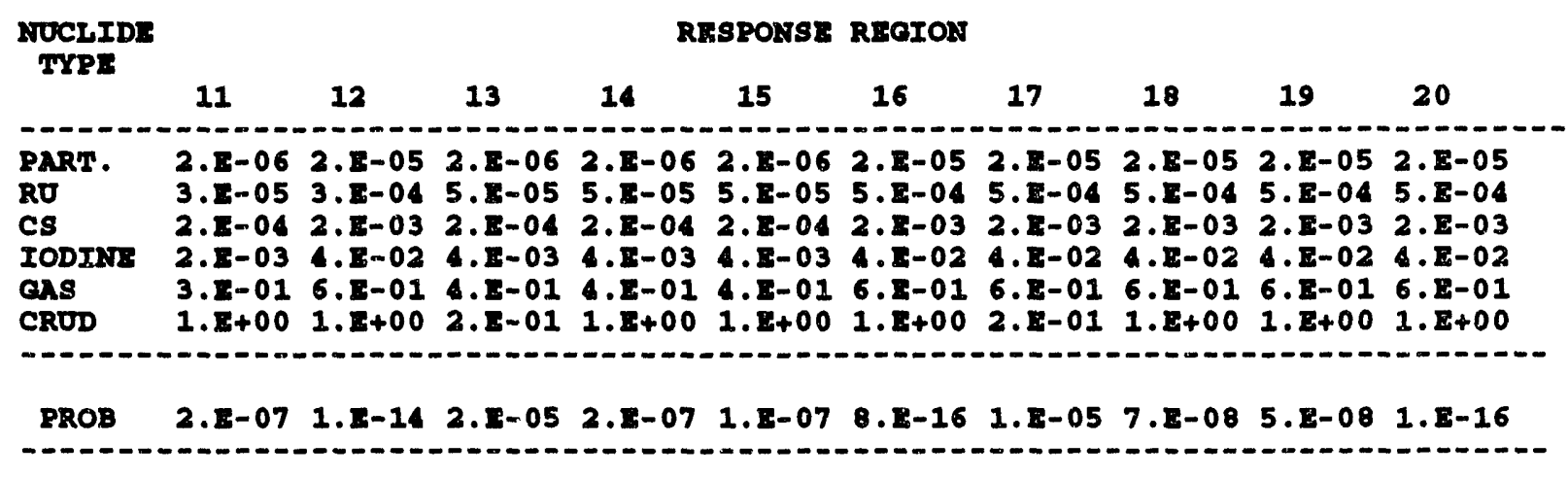




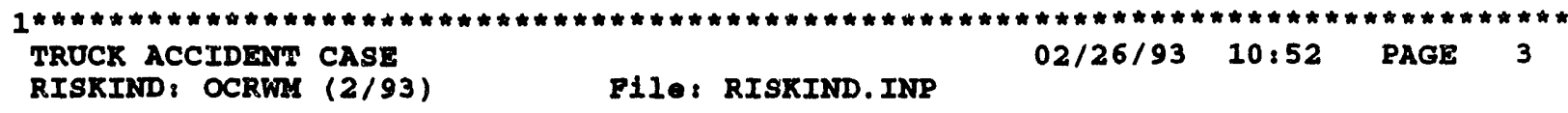

EXTERNAL DOSE RATE KULTIPLIER FOR EACE ACCIDENT RESPONSE REGION

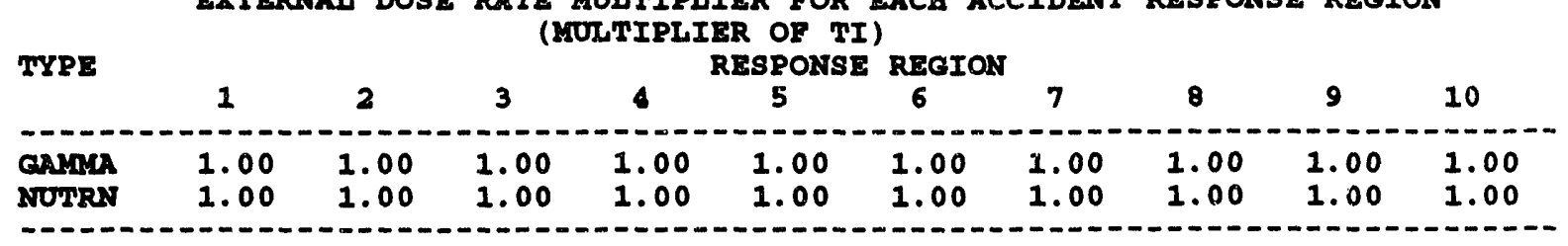

EXTERNAL DOSE RATE KULTIPLIER FOR EACE ACCIDENT RESPONSE REGION (MOLTIPLIER OF TI)

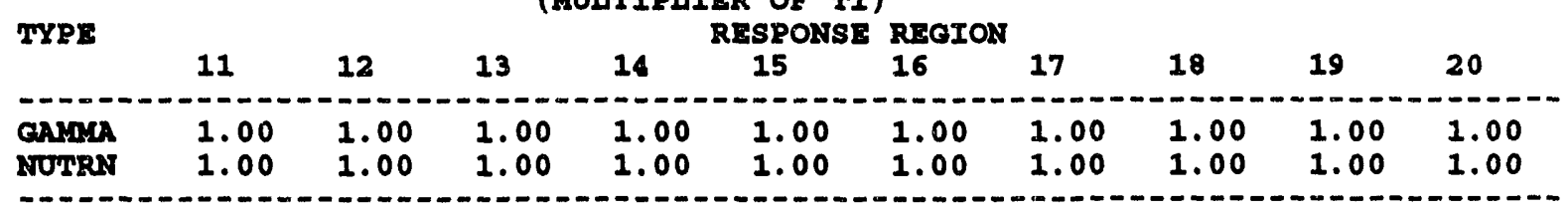




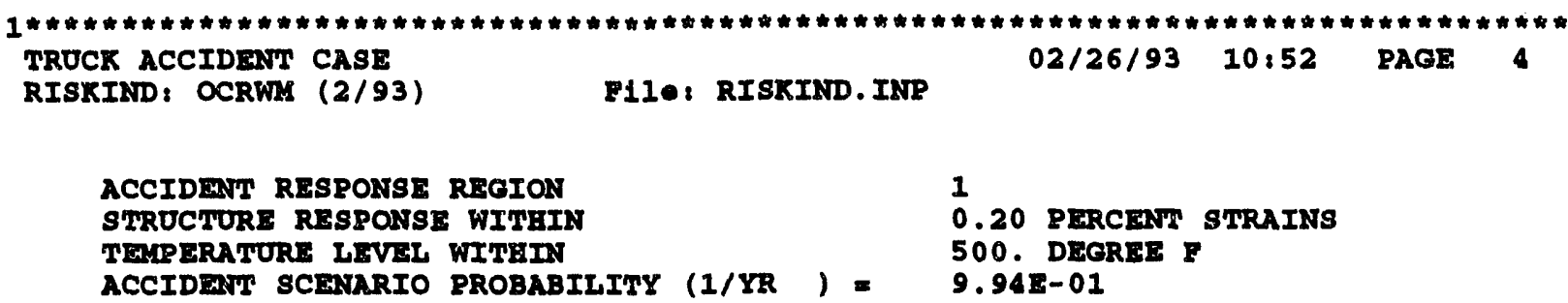

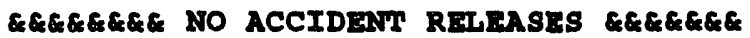




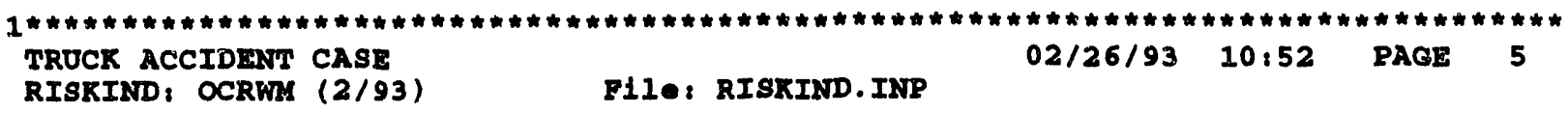

SUMEARY OF RECEPTOR POTENTIAL DOSE CONSEQUHNCES FATALITY AND GENETIC RISKS

I LOCATION NAMES

ACUIS:

EDE CHANCE

LONG TERY

DDE CHANCE

REA

FATALITY GENETIC.E

\begin{tabular}{|c|c|c|c|c|c|c|}
\hline $\begin{array}{ll}1 & \text { Nearest } \\
2 & \text { Nearevt } \\
3 & \text { Neareet } \\
4 & \text { Nearest }\end{array}$ & $\begin{array}{l}\text { Resident } \\
\text { Cas station } \\
\text { school } \\
\text { shopplng Mal }\end{array}$ & $\begin{array}{l}0.00 z+00 \\
0.00 z+00 \\
0.00 z+00 \\
0.00 z+00\end{array}$ & $\begin{array}{l}0.00 \mathrm{E}+00 \\
0.00 \mathrm{E}+00 \\
0.00 z+00 \\
0.00 \mathrm{z}+00\end{array}$ & $\begin{array}{l}0.00 \mathrm{E}+00 \\
0.00 \mathrm{E}+00 \\
0.00 \mathrm{E}+00 \\
0.00 \mathrm{E}+00\end{array}$ & $\begin{array}{l}0.00 \mathrm{E}+00 \\
0.00 \mathrm{E}+00 \\
0.00 \mathrm{E}+00 \\
0.00 \mathrm{E}+00\end{array}$ & $\begin{array}{l}0.00 \mathrm{E}+00 \\
0.00 \mathrm{E}+00 \\
0.00 \mathrm{E}+00 \\
0.00 \mathrm{E}+00\end{array}$ \\
\hline
\end{tabular}




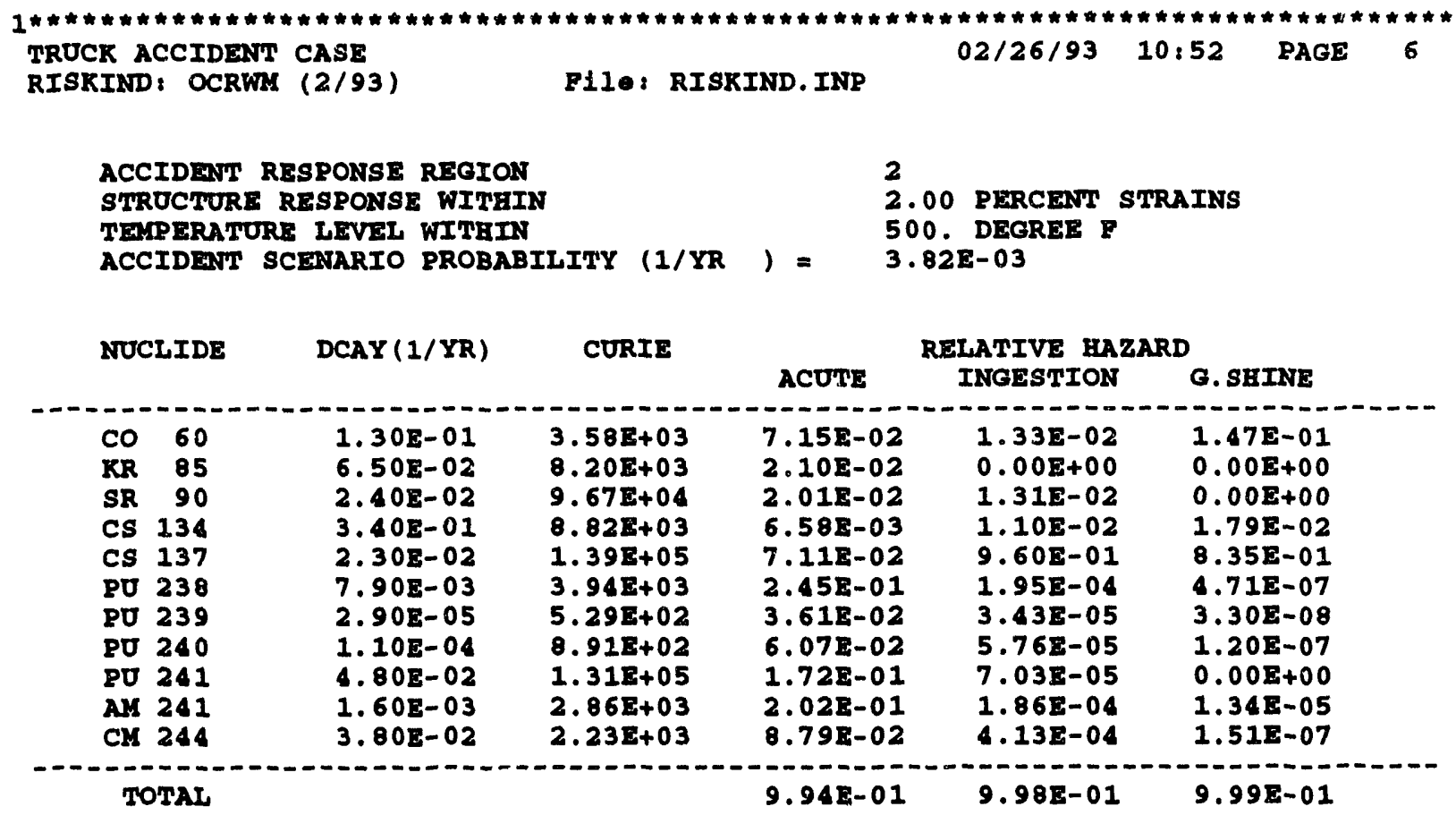




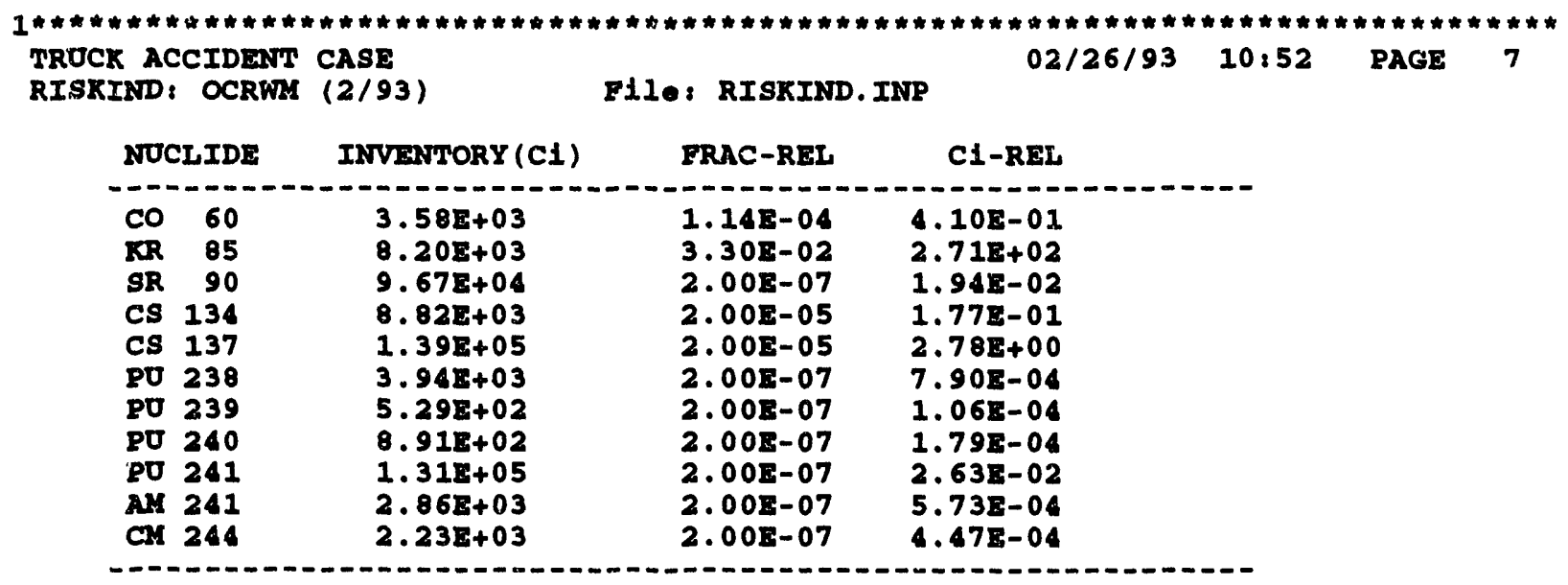

DISPERSION CAICULATION PARAMETERS :

PEYSICAL RELEASE HEIGET = SOURCE EPPECTIVE SIZE =

ANAYTTER BEIGET =

AMBIENT TEAPERATURE =

DRY DEPOSITION VELOCITY = DEPOSITION VHL OVER WATER = DEPOSITION VEL OVER VEGETATION =

$\begin{aligned} 1.00 & (K) \\ 2.19 & (K) \\ 10.00 & (K) \\ 293.00 & (K) \\ 0.005 & (K / S) \\ 0.010 & (K / S) \\ 0.010 & (K / S)\end{aligned}$

SUMDARY OF POTENTIAL DOSE CONSEQUENCES

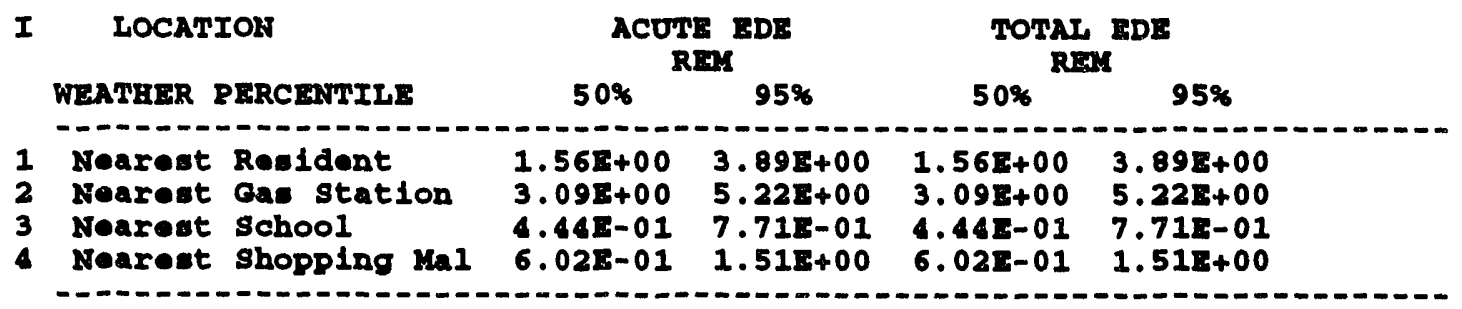

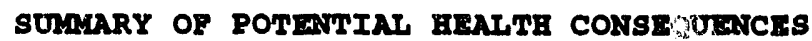

\begin{tabular}{|c|c|c|c|c|c|c|c|}
\hline \multirow[t]{2}{*}{$\mathbf{I}$} & LOCATION & \multicolumn{2}{|c|}{$\begin{array}{l}\text { ACUTE } \\
\text { PATALITY }\end{array}$} & \multicolumn{2}{|c|}{$\begin{array}{l}\text { IATANY } \\
\text { EATAIITY }\end{array}$} & \multicolumn{2}{|c|}{$\begin{array}{l}\text { GEARETC } \\
\text { EEPECT }\end{array}$} \\
\hline & (WEATHER PERCENTILE) & $50 \%$ & $95 \%$ & $50 \%$ & $95 \%$ & $50 \%$ & $95 \%$ \\
\hline & $\begin{array}{l}\text { Neareat Realdent } \\
\text { Nearest Gas station } \\
\text { Nearest school } \\
\text { Nearest shopping Mal }\end{array}$ & $\begin{array}{l}0.00 \mathrm{E}+00 \\
0.00 \mathrm{E}+00 \\
0.00 \mathrm{E}+00 \\
0.00 \mathrm{E}+00\end{array}$ & $\begin{array}{l}0.00 E+00 \\
0.00 E+00 \\
0.00 E+00 \\
0.00 E+00\end{array}$ & $\begin{array}{l}1.25 \mathrm{~g}-03 \\
2.47 \mathrm{E}-03 \\
3.55 \mathrm{z}-04 \\
4.82 \mathrm{z}-04\end{array}$ & $\begin{array}{l}3.11 E-03 \\
4.18 E-03 \\
6.17 E-04 \\
1.21 E-03\end{array}$ & $\begin{array}{l}3.12 \mathrm{E}-04 \\
6.18 \mathrm{E}-04 \\
8.89 \mathrm{E}-05 \\
1.20 \mathrm{z}-04\end{array}$ & $\begin{array}{l}7.78 \mathrm{E}-04 \\
1.04 \mathrm{E}-03 \\
1.54 \mathrm{E}-04 \\
3.01 \mathrm{E}-04\end{array}$ \\
\hline
\end{tabular}




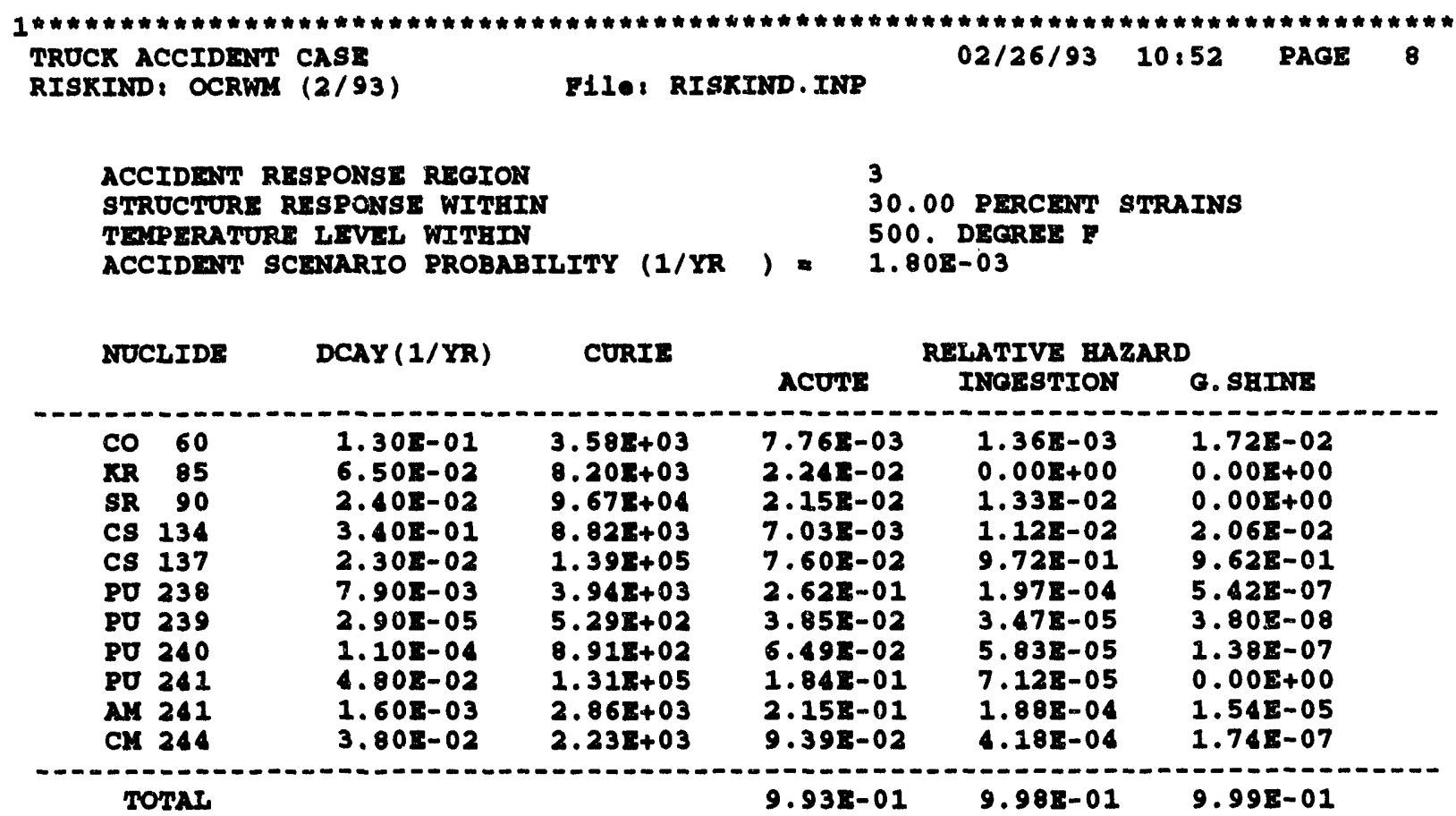




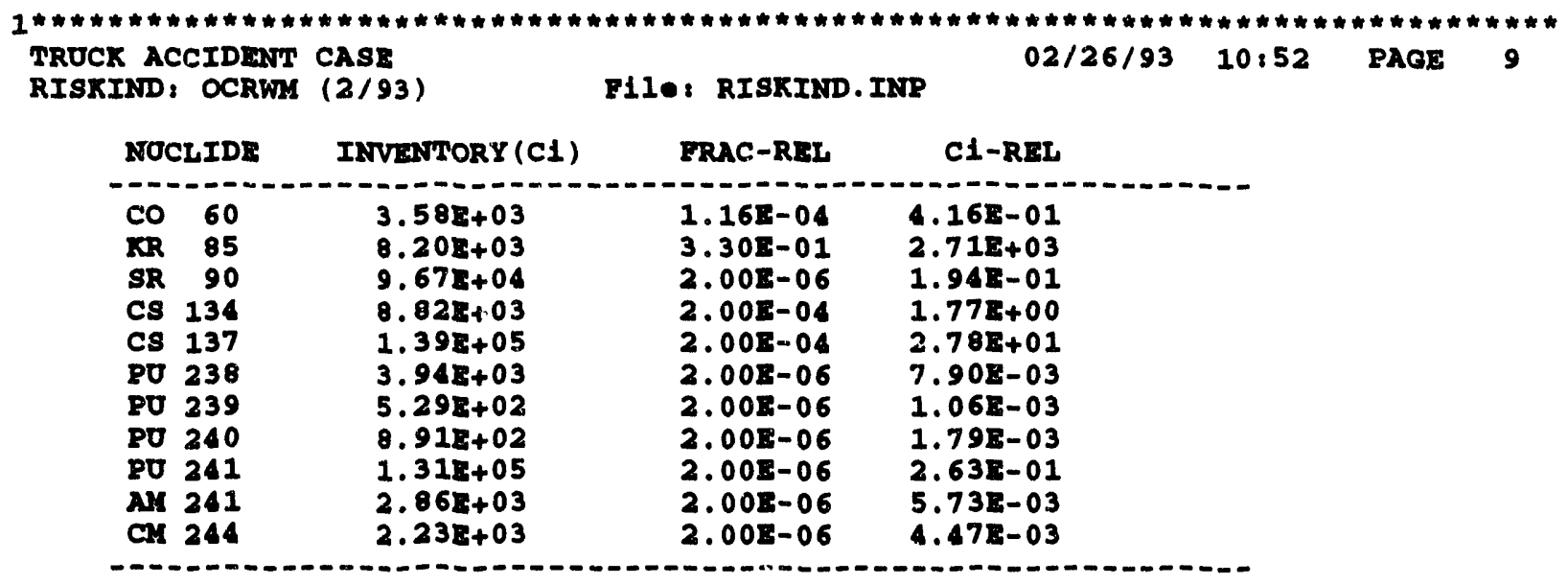

SUMAARY OF POTENTIAL DOSE CONSEQUATCES

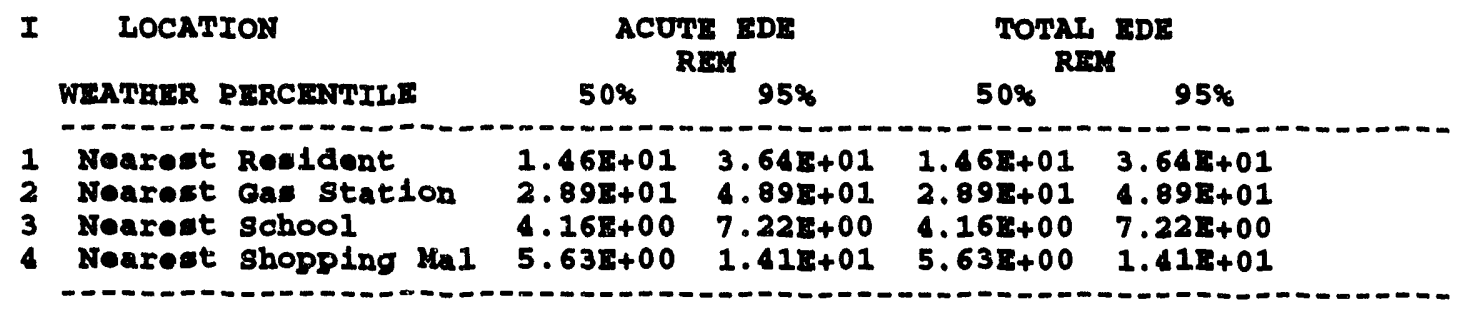

SOLLARY OF POTENTIAI GEALTE CONSEQUEYCES

\begin{tabular}{|c|c|c|c|c|c|c|}
\hline LOCATION & $\begin{array}{r}\text { ACI } \\
\text { EAT }\end{array}$ & $\begin{array}{l}\text { TrE } \\
\text { ILITY }\end{array}$ & $\begin{array}{r}\text { IAT } \\
\text { FAT }\end{array}$ & $\begin{array}{l}\text { DENST } \\
\text { NITY }\end{array}$ & $\begin{array}{l}\text { GENTE } \\
\text { EFER }\end{array}$ & TIC \\
\hline (WEATERR PERCENTILE) & $50 \%$ & $95 \%$ & $50 \%$ & $95 \%$ & $50 \%$ & $95 \%$ \\
\hline $\begin{array}{l}1 \text { Nearest Resident } \\
2 \text { Nearest Gas station } \\
3 \text { Nearest School } \\
4 \text { Nearest Shopping Mal }\end{array}$ & $\begin{array}{l}0.00 \mathrm{E}+00 \\
0.00 \mathrm{E}+00 \\
0.00 \mathrm{E}+00 \\
0.00 \mathrm{E}+00\end{array}$ & $\begin{array}{l}0.00 \mathrm{E}+00 \\
0.00 \mathrm{E}+00 \\
0.00 \mathrm{E}+00 \\
0.00 \mathrm{E}+00\end{array}$ & $\begin{array}{l}1.17 \mathrm{E}-02 \\
2.31 \mathrm{E}-02 \\
3.33 \mathrm{E}-03 \\
4.51 \mathrm{E}-03\end{array}$ & $\begin{array}{l}2.91 \mathrm{E}-02 \\
3.91 \mathrm{~B}-02 \\
5.77 \mathrm{E}-03 \\
1.13 \mathrm{E}-02\end{array}$ & $\begin{array}{l}2.92 z-03 \\
5.78 z-03 \\
8.32 z-04 \\
1.13 E-03\end{array}$ & $\begin{array}{l}7.28 \mathrm{z}-03 \\
9.78 \mathrm{z}-03 \\
1.44 \mathrm{E}-03 \\
2.82 \mathrm{z}-03\end{array}$ \\
\hline
\end{tabular}




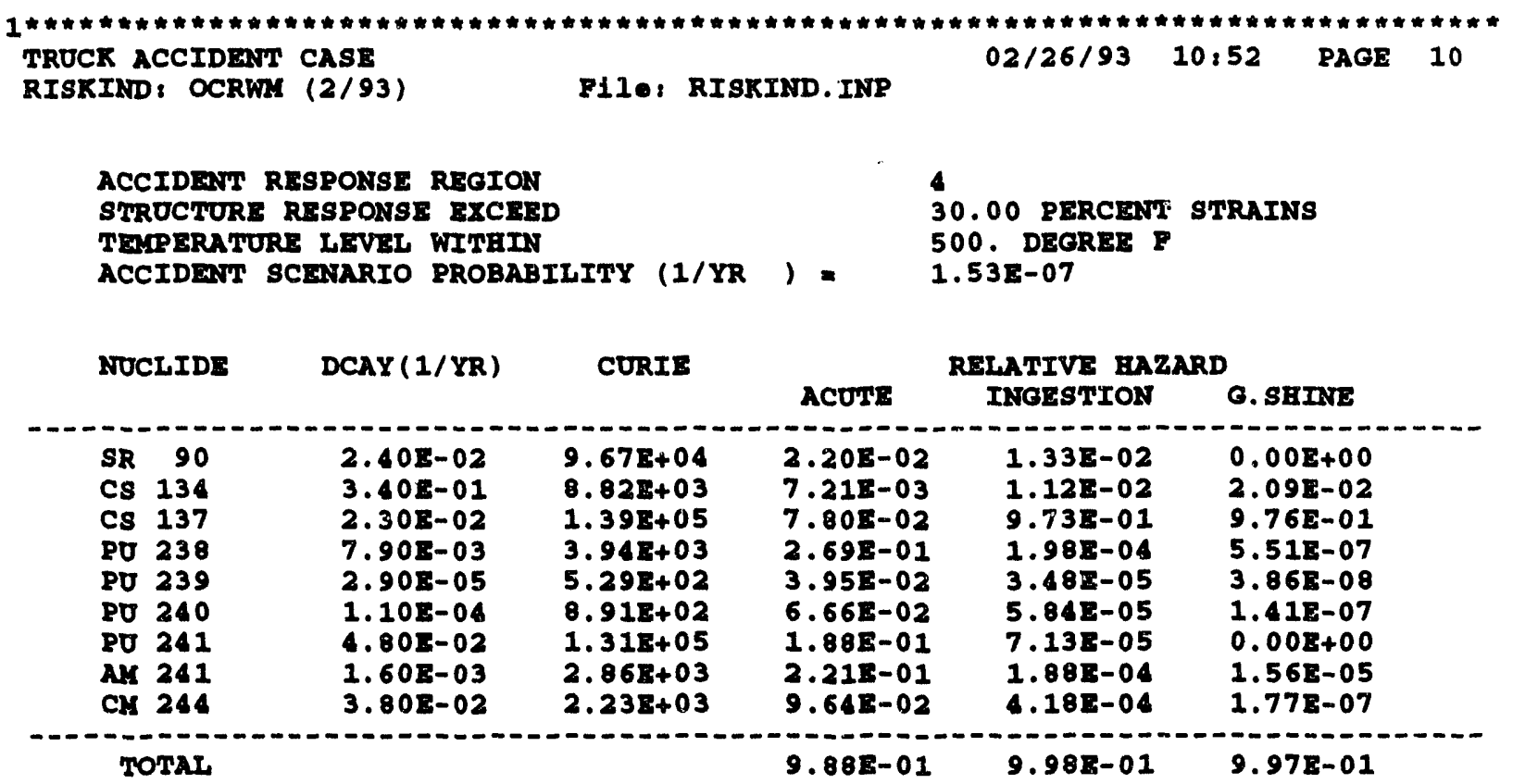




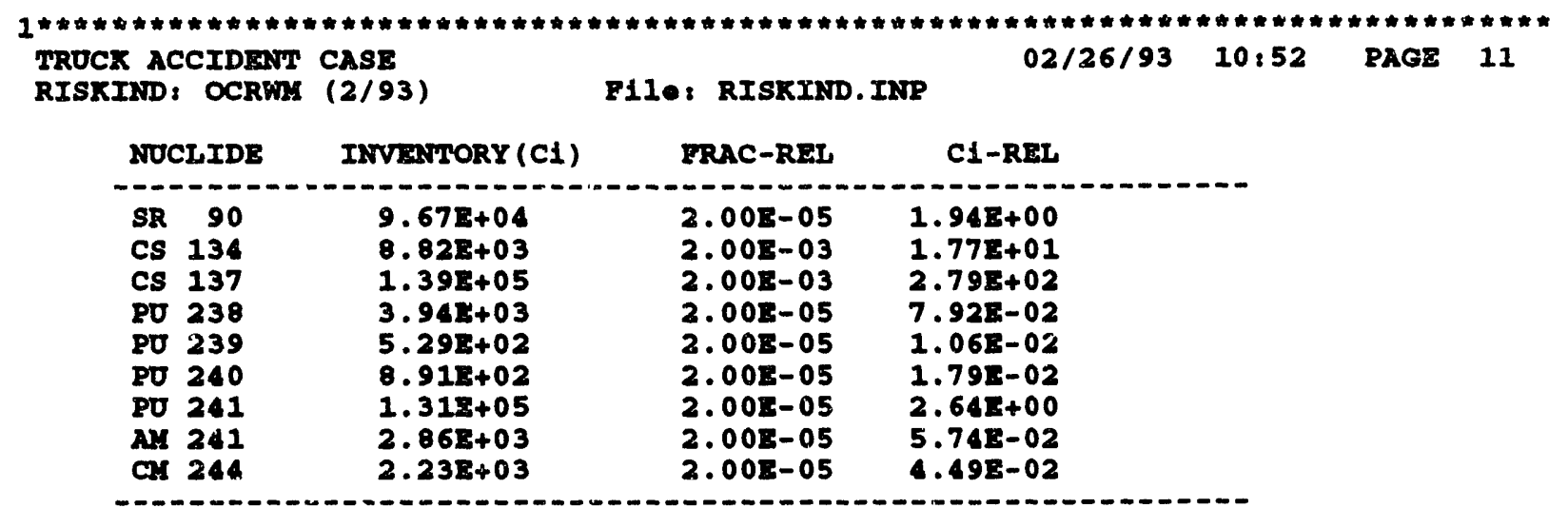

SUDYRY OF POTENTIAI DOSE CONSEQUMACES

\begin{tabular}{|c|c|c|c|c|c|}
\hline$I$ & LOCATION & $x c 0$ & EDE & TOTA & EDE \\
\hline & TEATEER PERCENILE & $50 \%$ & $95 \%$ & $50 \%$ & $95 \%$ \\
\hline & $\begin{array}{l}\text { Nearest Resident } \\
\text { Nearoet Gas station } \\
\text { Nearest School } \\
\text { Neareat shopping Mal }\end{array}$ & $\begin{array}{l}1.42 E+02 \\
2.81 E+02 \\
4.03 E+01 \\
5.472+01\end{array}$ & $\begin{array}{l}3.54 \mathrm{z}+02 \\
4.75 \mathrm{E}+02 \\
7.00 \mathrm{E}+01 \\
1.37 \mathrm{E}+02\end{array}$ & $\begin{array}{l}1.42 \mathrm{E}+02 \\
2.81 \mathrm{E}+02 \\
4.03 \mathrm{E}+01 \\
5.47 \mathrm{E}+01\end{array}$ & $\begin{array}{l}3.545+02 \\
4.75 z+02 \\
7.002+01 \\
1.378+02\end{array}$ \\
\hline
\end{tabular}

SOMLARY OF POTEMIAT HEATE CONSEOUENCES

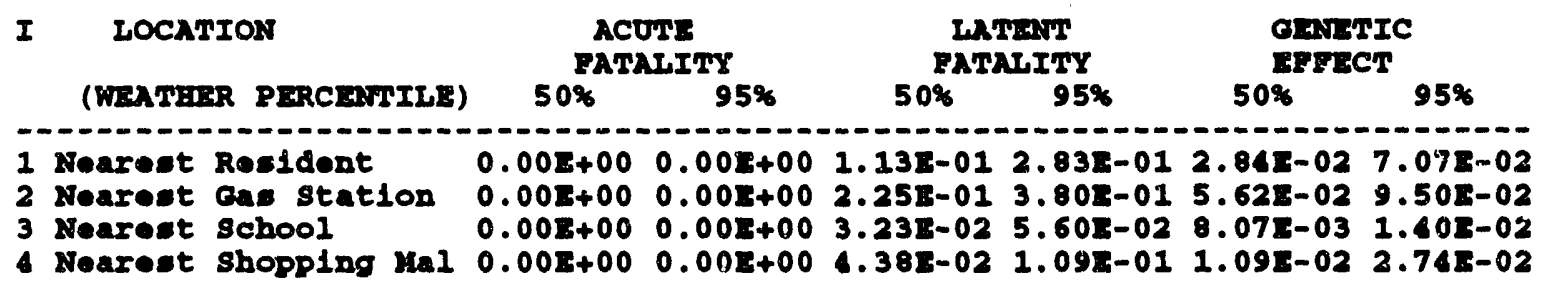




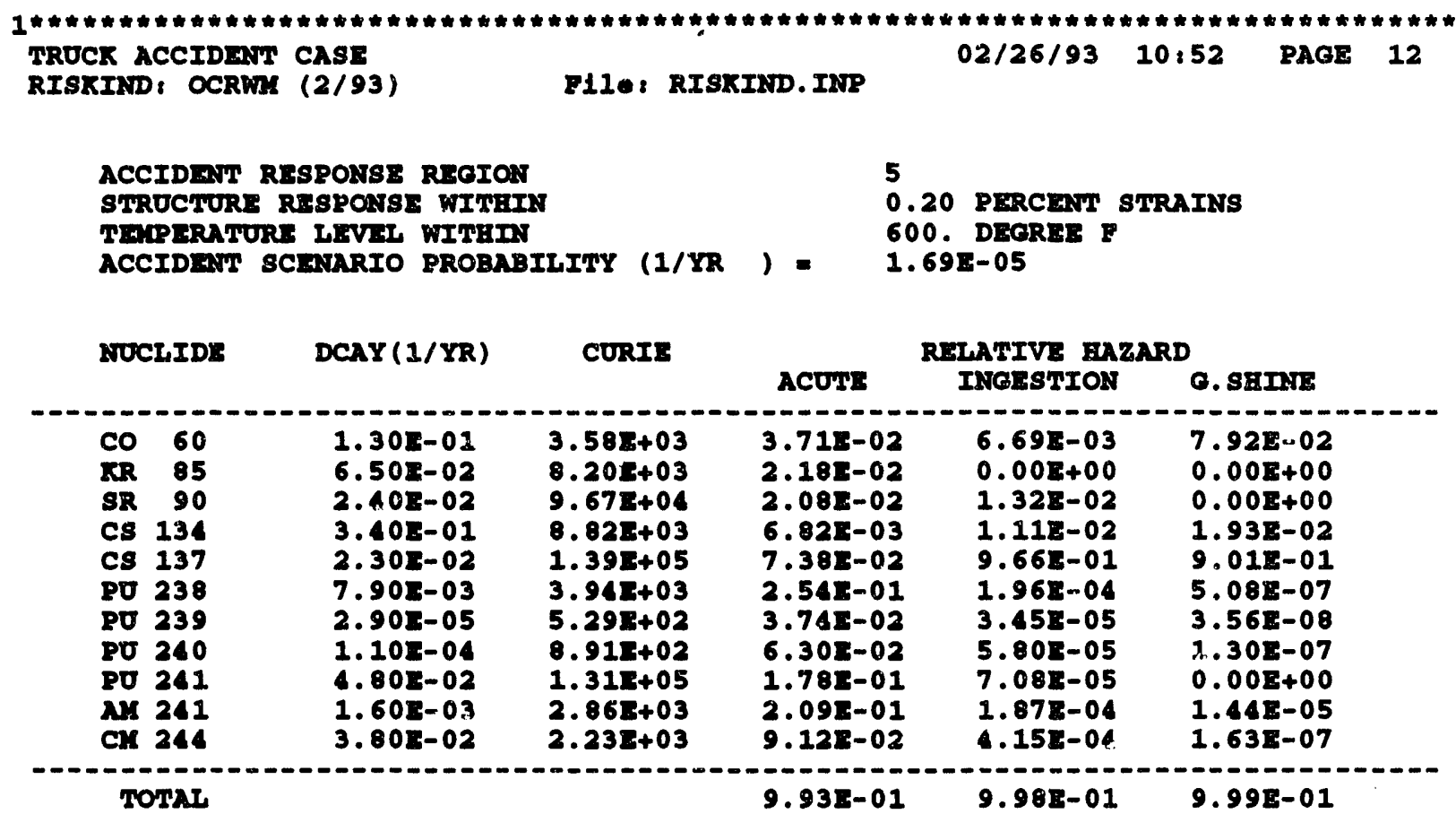




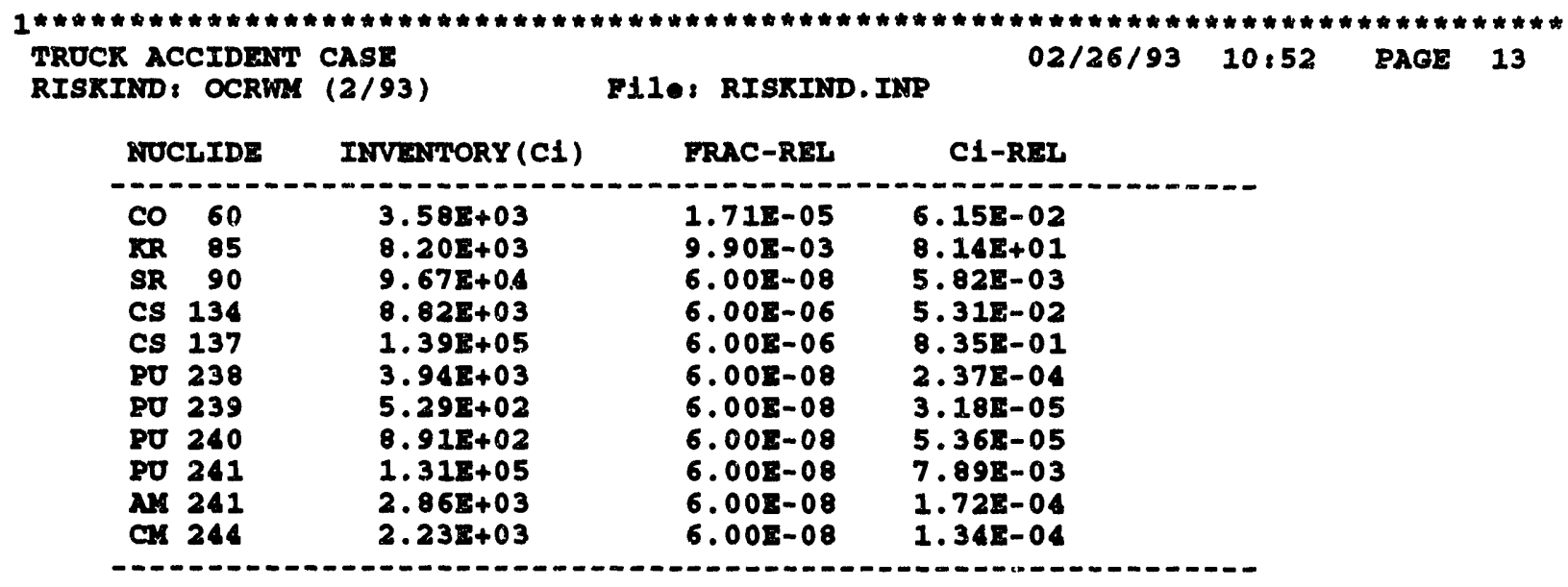

SUMARX OF POTENIIAI DOSE CONSEQUENCES

\begin{tabular}{|c|c|c|c|c|c|c|}
\hline I & LOCAI & ION & $\mathrm{ACO}$ & 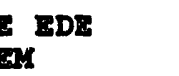 & $\operatorname{Tot} \alpha$ & EDE \\
\hline & WEATEER & PERCENTILE & $50 \%$ & $95 \%$ & $50 \%$ & $95 \%$ \\
\hline & $\begin{array}{l}\text { Nearent } \\
\text { Neareet } \\
\text { Neareet } \\
\text { Nearent }\end{array}$ & $\begin{array}{l}\text { Realdont } \\
\text { Gas station } \\
\text { school } \\
\text { shopplng Mal }\end{array}$ & $\begin{array}{l}1.24 \mathrm{z}-02 \\
4.50 \mathrm{z}-03 \\
3.18 \mathrm{z}-02 \\
2.93 \mathrm{z}-02\end{array}$ & $\begin{array}{l}7.89 z-02 \\
6.32 z-02 \\
4.92 \Sigma-02 \\
6.52 z-02\end{array}$ & $\begin{array}{l}1.24 \mathrm{z}-02 \\
4.50 \mathrm{z}-03 \\
3.18 \mathrm{~s}-02 \\
2.93 \mathrm{z}-02\end{array}$ & $\begin{array}{l}7.89 \mathrm{E}-02 \\
6.32 \mathrm{E}-02 \\
4.92 \mathrm{E}-02 \\
6.52 \mathrm{E}-02\end{array}$ \\
\hline
\end{tabular}

SULARY OF POTEMTIAI BEALTH CONSEOUINCES

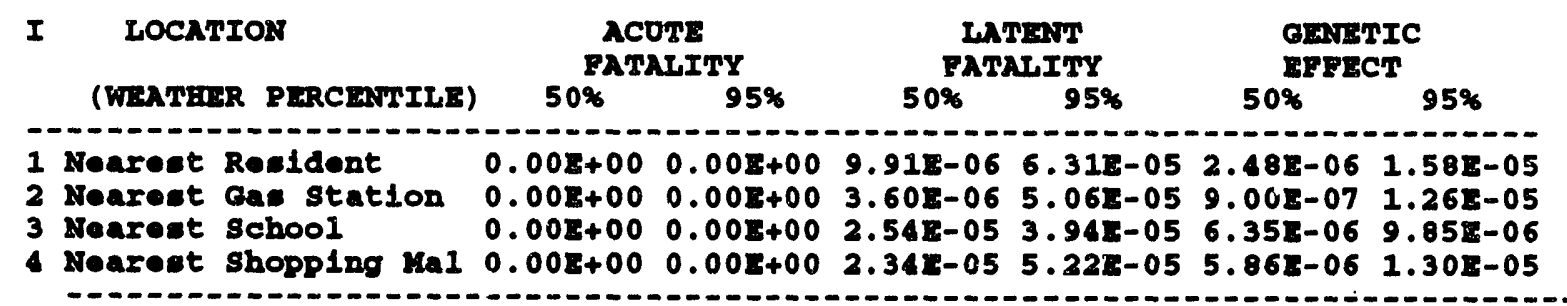




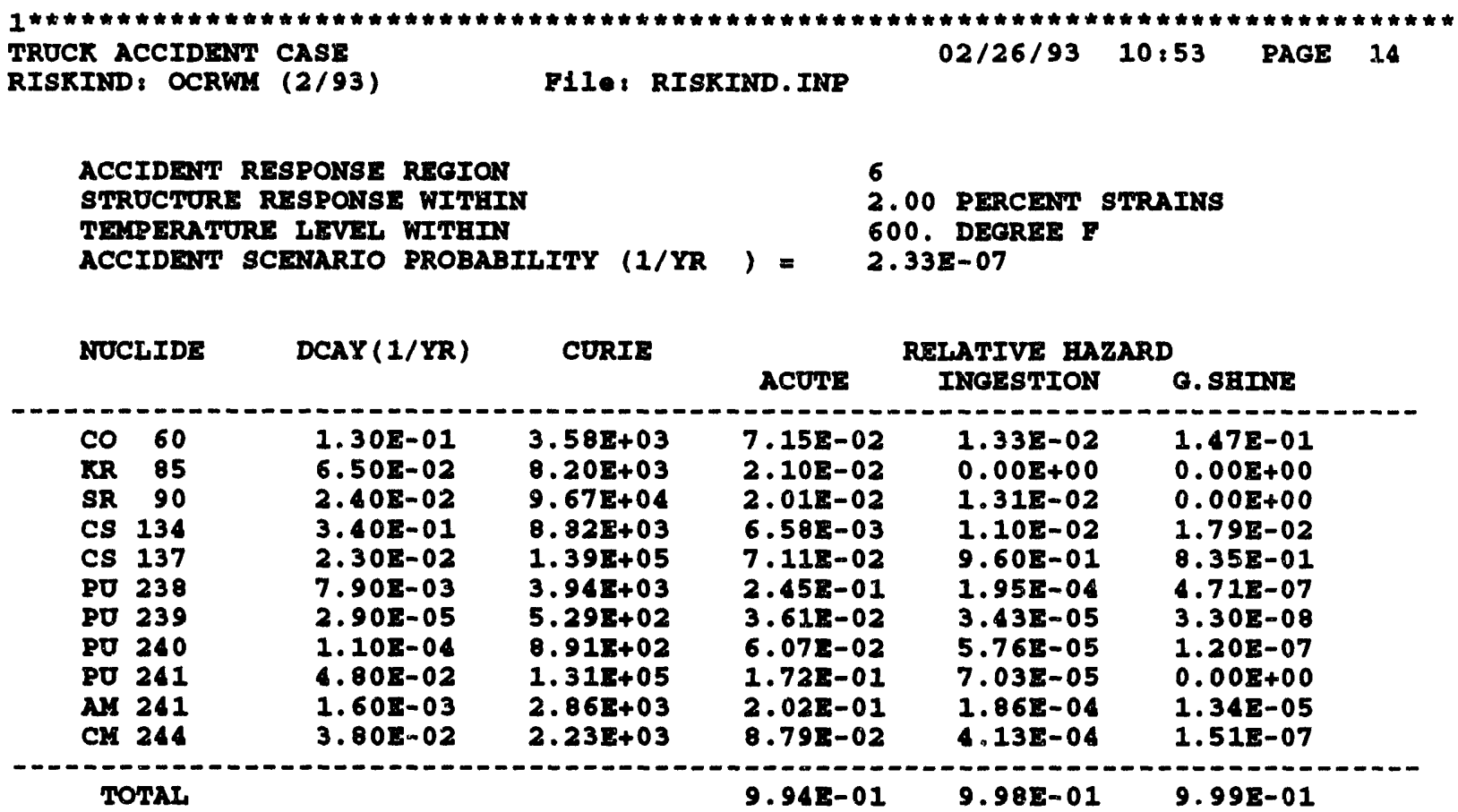




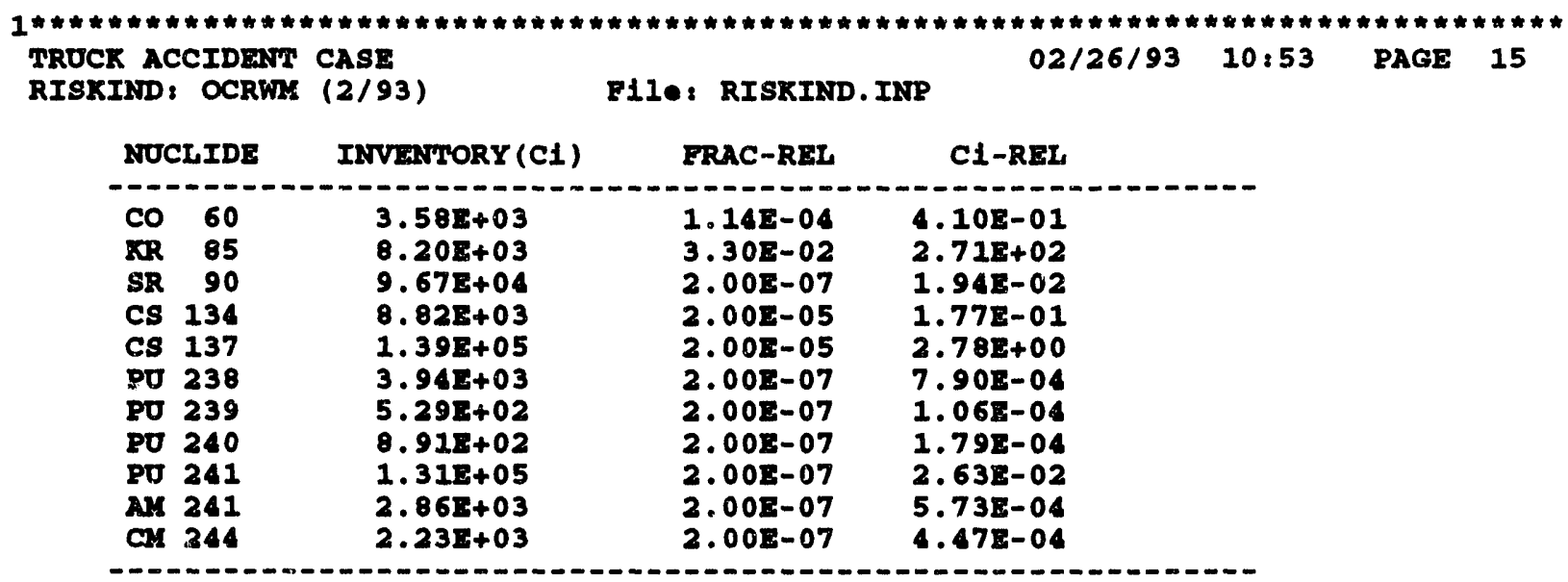

SULMARY OP POTENTIAI DOSE CONGEQUENCES

\begin{tabular}{|c|c|c|c|c|c|}
\hline & LOCATION & $A C O$ & EDE & $\begin{array}{r}\text { TOTA } \\
R\end{array}$ & EDE \\
\hline & VRATEER PERCANTILE & $50 \%$ & $95 \%$ & $50 \%$ & $95 \%$ \\
\hline & $\begin{array}{l}\text { Neareet Resident } \\
\text { Nearent Gas station } \\
\text { Nearest school } \\
\text { Nearent shopplag kal }\end{array}$ & $\begin{array}{l}1.28 z-02 \\
1.56 z-02 \\
1.102-01 \\
1.01 z-01\end{array}$ & $\begin{array}{l}2.73 E-01 \\
2.19 E-01 \\
1.70 z-01 \\
2.25 E-01\end{array}$ & $\begin{array}{l}4.28 \mathrm{z}-02 \\
1.56 \mathrm{z}-02 \\
1.10 \mathrm{z}-01 \\
1.01 \mathrm{z}-01\end{array}$ & $\begin{array}{l}2.73 z-01 \\
2.195-01 \\
1.70 z-01 \\
2.25 z-01\end{array}$ \\
\hline
\end{tabular}

SUMLARY OF POTEATIAL HEALTE CONSEQUANCES

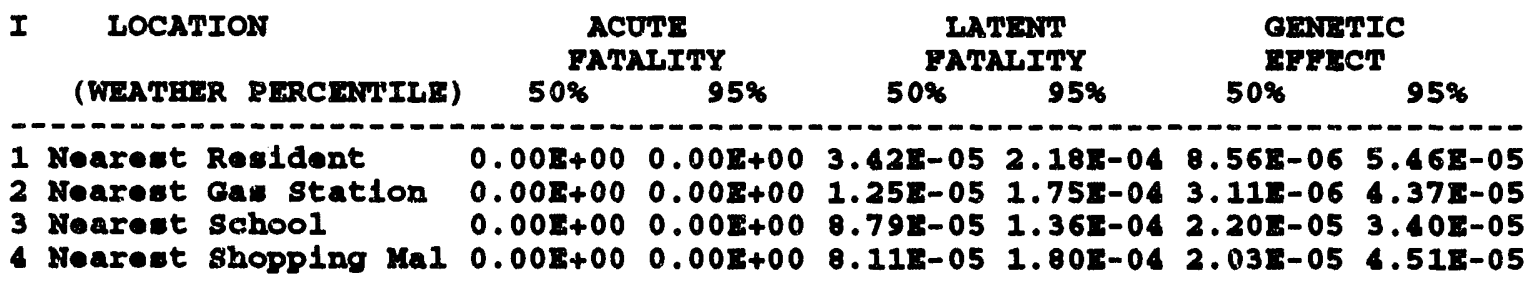




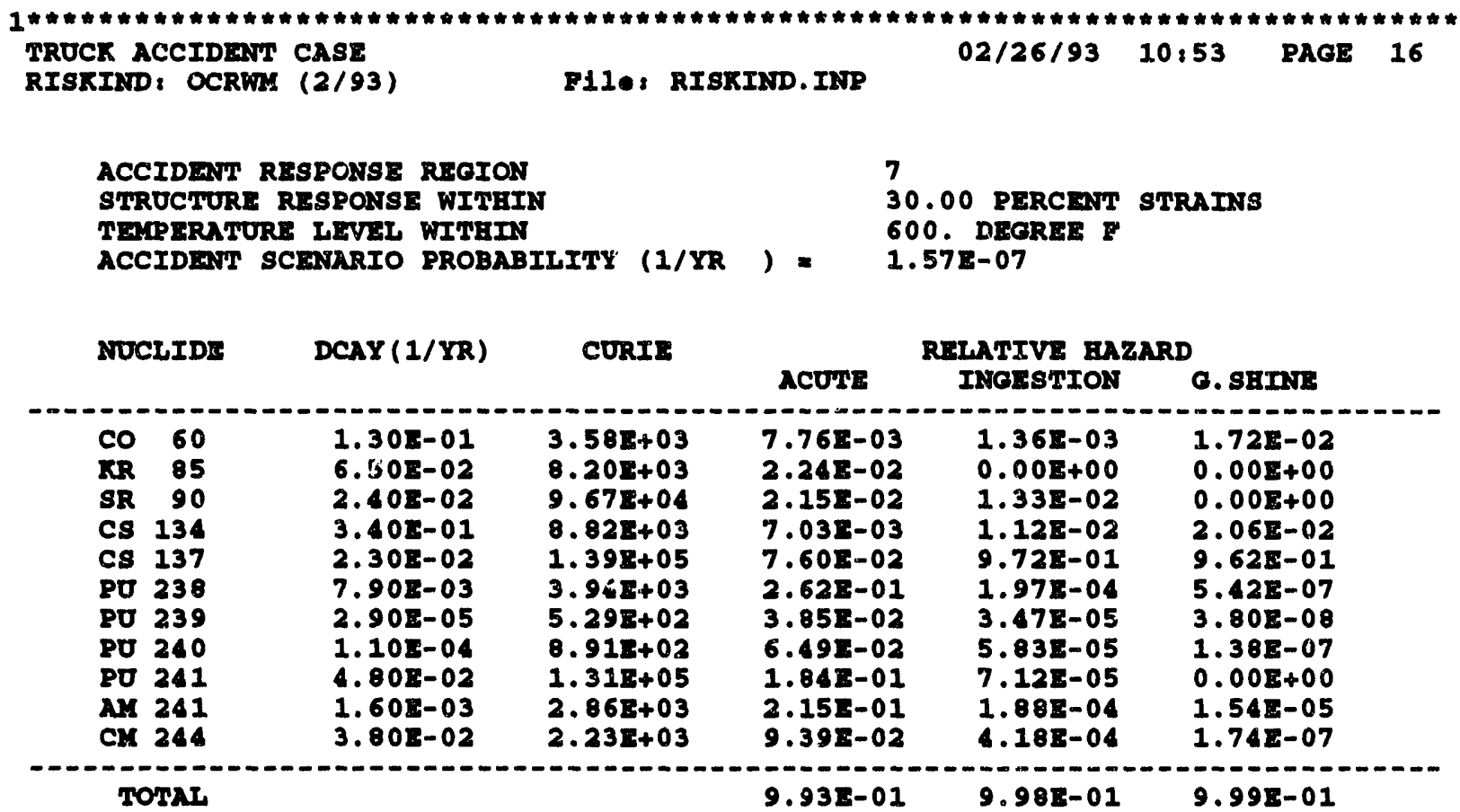




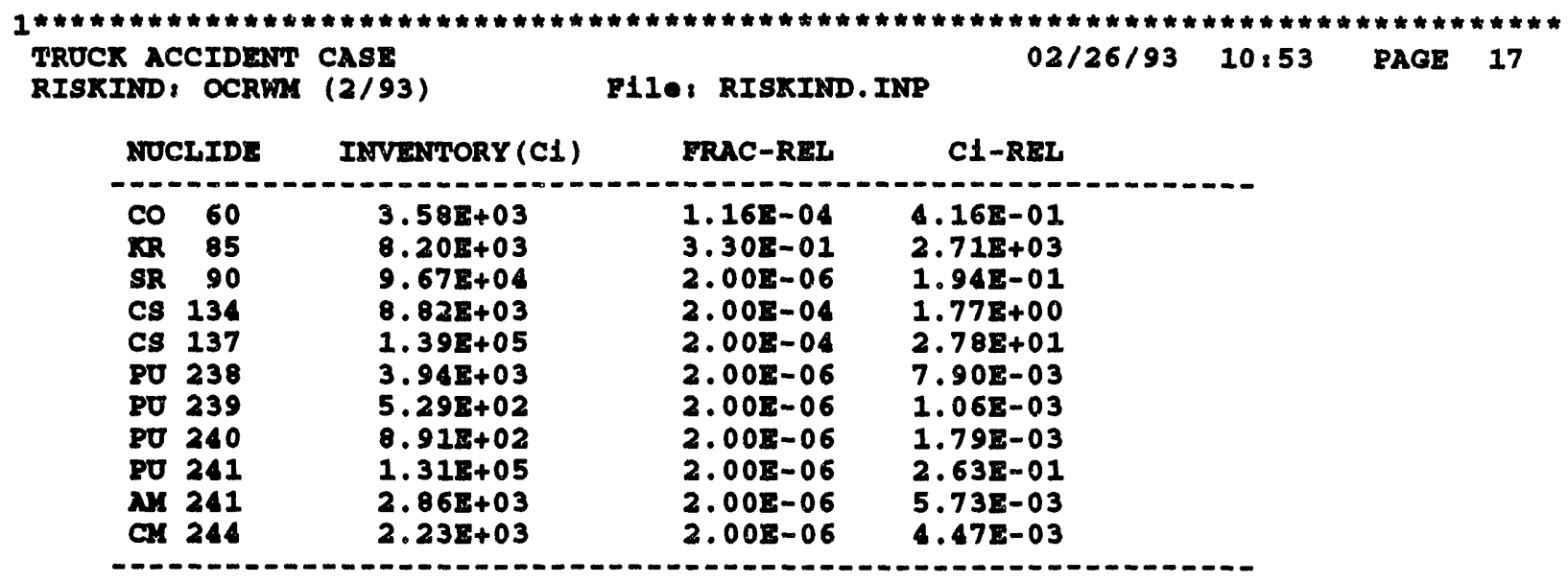

SUAARY OE POTENTIAL DOSE CONSEQUANCES

\begin{tabular}{|c|c|c|c|c|c|}
\hline LOCAT & ION & $\mathrm{ACO}$ & EDE & $\begin{array}{r}\text { TOTA } \\
R\end{array}$ & EDE \\
\hline WEATEER & PERCENTILE & $50 \%$ & $95 \%$ & $50 \%$ & $95 \%$ \\
\hline $\begin{array}{l}\text { Nearest } \\
\text { Neareat } \\
\text { Nearest } \\
\text { Neareat }\end{array}$ & $\begin{array}{l}\text { Rosldont } \\
\text { Gas station } \\
\text { School } \\
\text { shopplng Mal }\end{array}$ & $\begin{array}{l}4.01 E-01 \\
1.46 z-01 \\
1.03 E+00 \\
9.48 z-01\end{array}$ & $\begin{array}{l}2.55 z+00 \\
2.045+00 \\
1.59 z+00 \\
2.11 E+00\end{array}$ & $\begin{array}{l}4.012-01 \\
1.46 z-01 \\
1.032+00 \\
9.485-01\end{array}$ & $\begin{array}{l}2.55 z+00 \\
2.04 E+00 \\
1.59 z+00 \\
2.11 E+00\end{array}$ \\
\hline
\end{tabular}

SUMARY OE POTEMTIA HEATTE CONSEOUMNCES

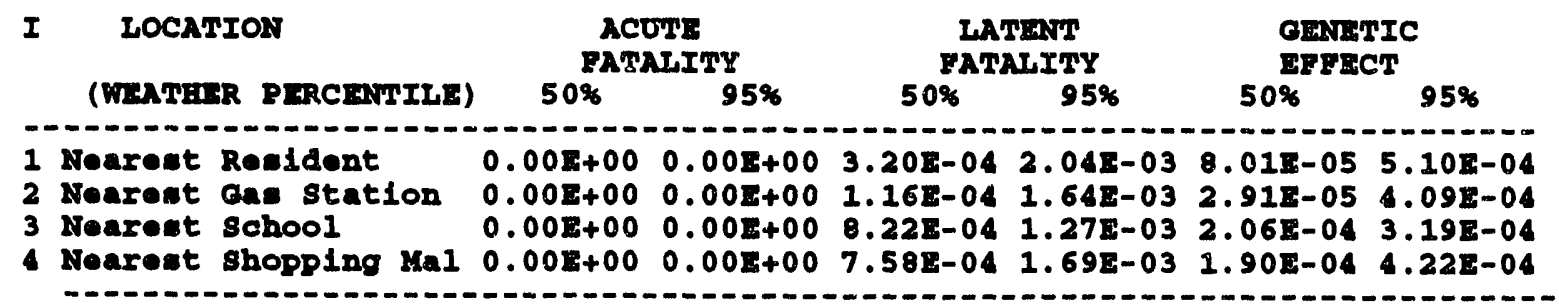




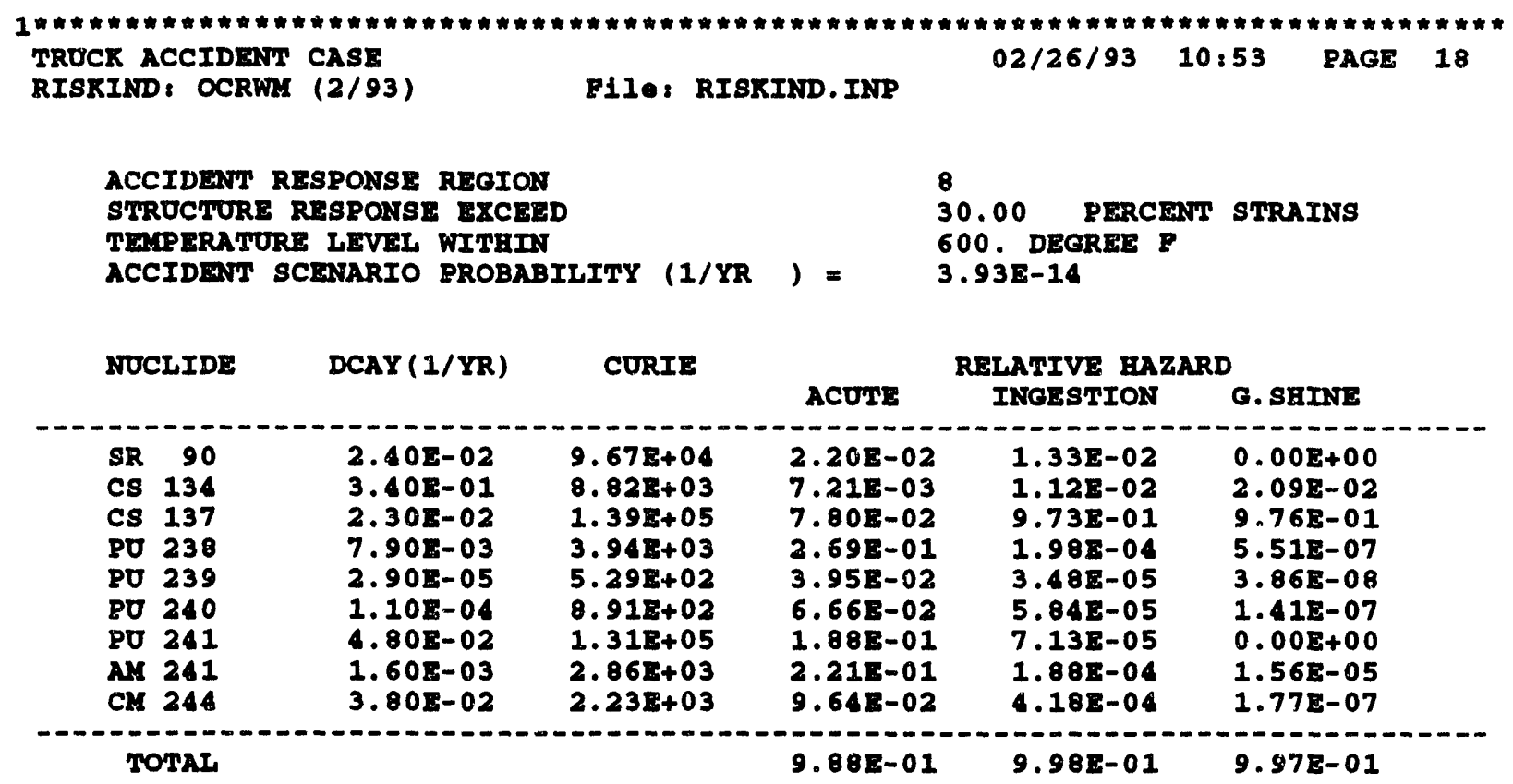




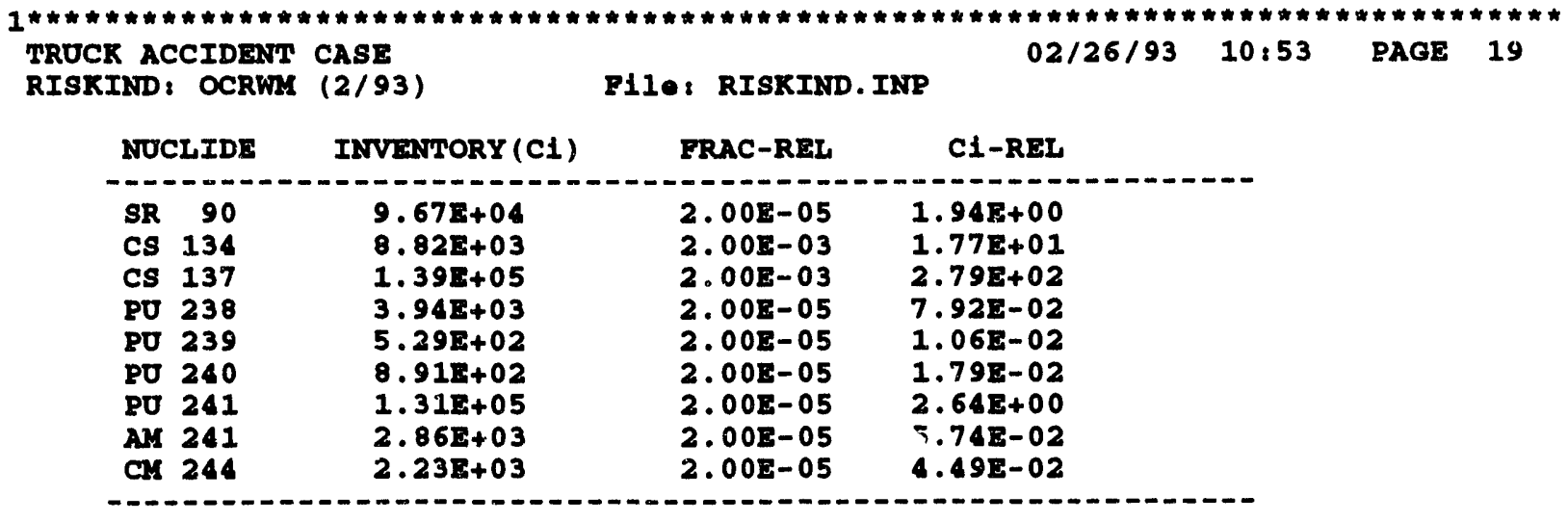

SURMLAY OF POTENMIAL DOSE CONSERUENCES

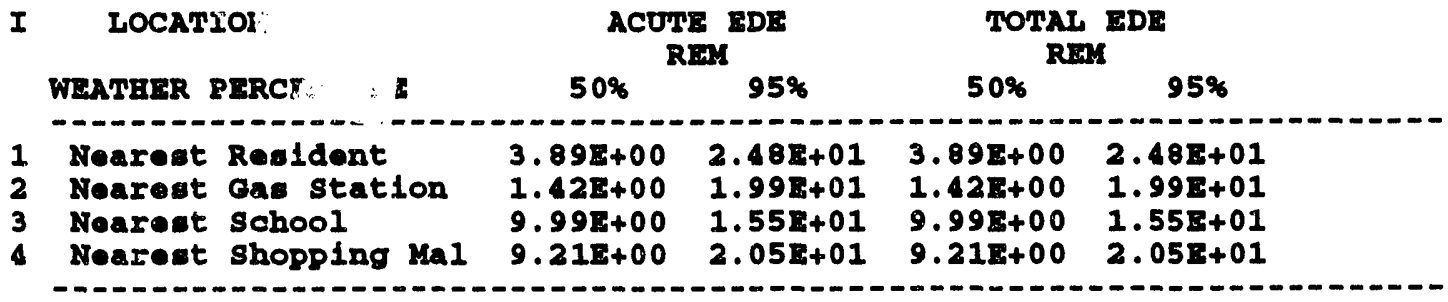

\section{SURMARY OF POTHNTIAL HEALTE CONSEQUENCES}

I LOCATION (WRATKOR RERCANTILE)

ACUTE
EATALITY

$50 \%$

95\%

IATENT
FATALITY
$50 \%$ 95\%

GANETIC EFPECT

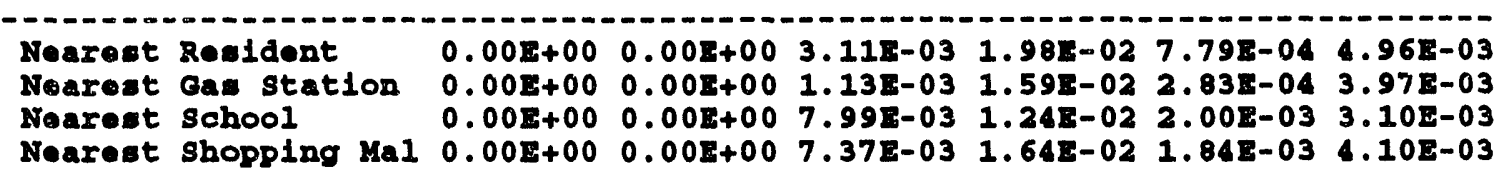




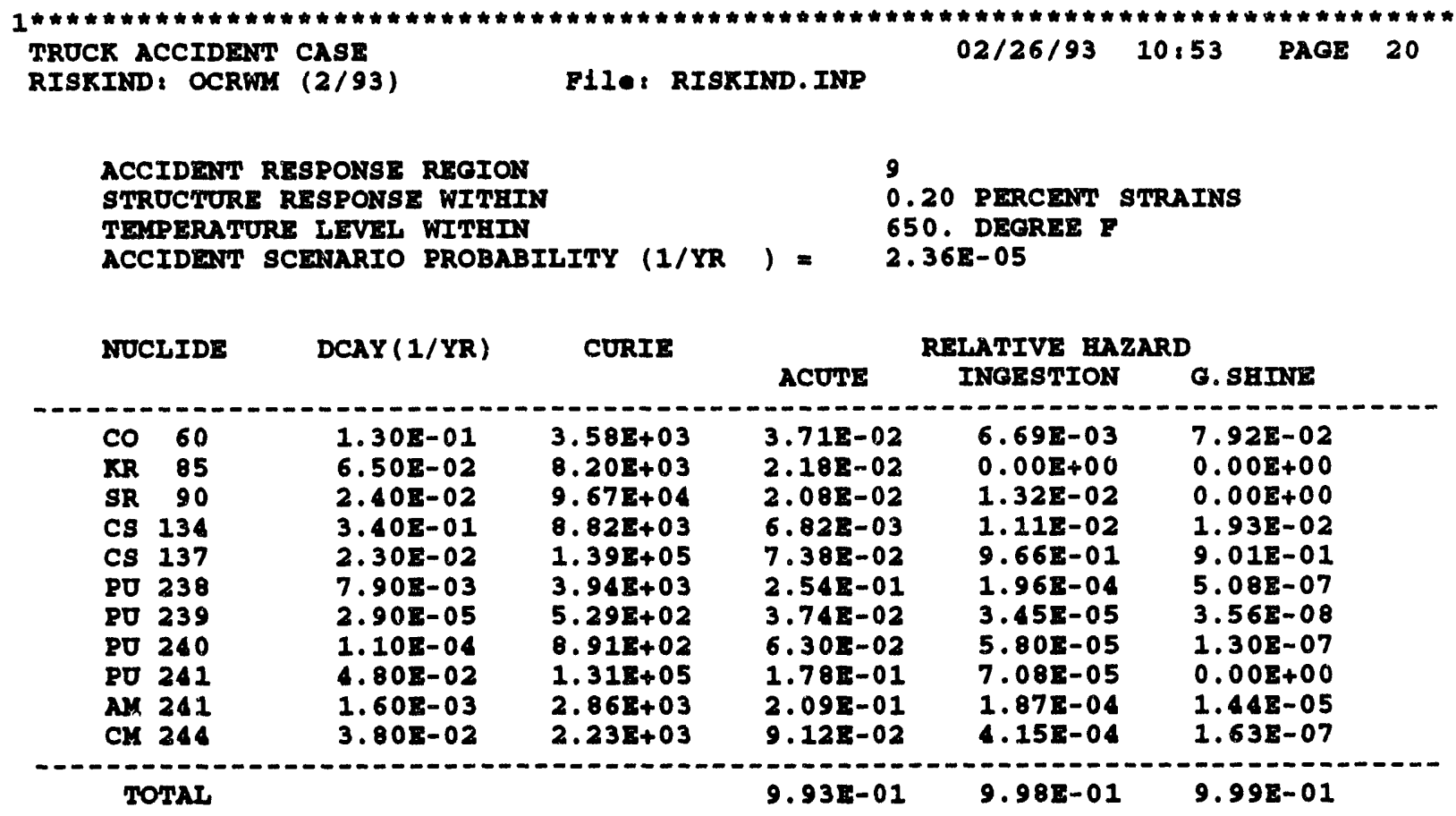




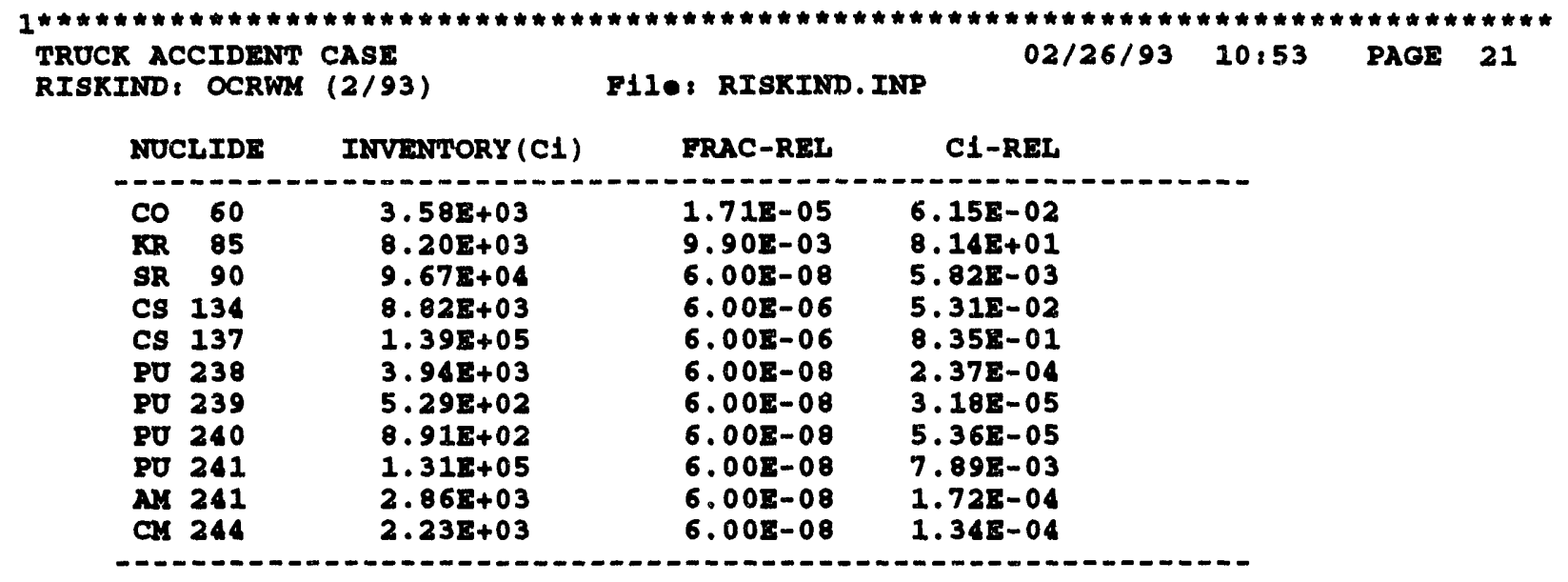

SURAARY OE POTENTIAL DOSE CONSEOUENCES

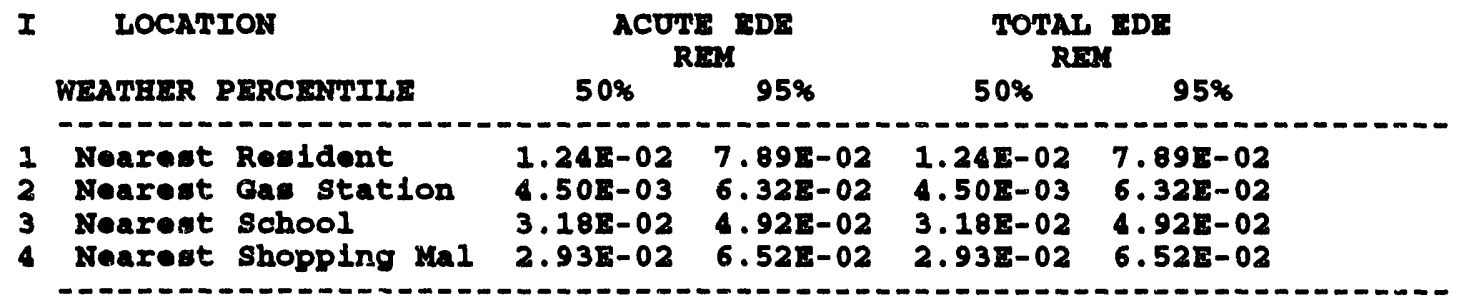

SUXLARY OP POTENTIA工 HEALTE CONSEOUENCES

\begin{tabular}{|c|c|c|c|c|c|c|c|}
\hline \multicolumn{2}{|r|}{ LOCATION } & \multicolumn{2}{|c|}{$\begin{array}{l}\text { ACUTR } \\
\text { FATAIITY }\end{array}$} & \multicolumn{2}{|c|}{$\begin{array}{l}\text { LATENT } \\
\text { EATALITY }\end{array}$} & \multicolumn{2}{|c|}{$\begin{array}{l}\text { GENETIC } \\
\text { EFPECT }\end{array}$} \\
\hline & (WEATERR PERCENTILE) & $50 \%$ & $95 \%$ & $50 \%$ & $95 \%$ & $50 \%$ & $95 \%$ \\
\hline & $\begin{array}{l}\text { Nearest Resident } \\
\text { Nearest Ga station } \\
\text { Nearest School } \\
\text { Nearest shopplng Mal }\end{array}$ & $\begin{array}{l}0.00 \mathrm{z}+00 \\
0.00 \mathrm{z}+00 \\
0.00 \mathrm{z}+00 \\
0.00 \mathrm{z}+00\end{array}$ & $\begin{array}{l}0.00 \mathrm{E}+00 \\
0.00 \mathrm{E}+00 \\
0.00 \mathrm{E}+00 \\
0.00 \mathrm{E}+00\end{array}$ & $\begin{array}{l}9.91 z-06 \\
3.60 z-06 \\
2.545-05 \\
2.345-05\end{array}$ & $\begin{array}{l}6.31 \mathrm{~B}-05 \\
5.06 \mathrm{-}-05 \\
3.94 \mathrm{~s}-05 \\
5.22 \mathrm{E}-05\end{array}$ & $\begin{array}{l}2.48 z-06 \\
9.00 z-07 \\
6.35 z-06 \\
5.86 z-06\end{array}$ & $\begin{array}{l}1.58 z-05 \\
1.26 z-05 \\
9.85 z-06 \\
1.30 z-05\end{array}$ \\
\hline
\end{tabular}




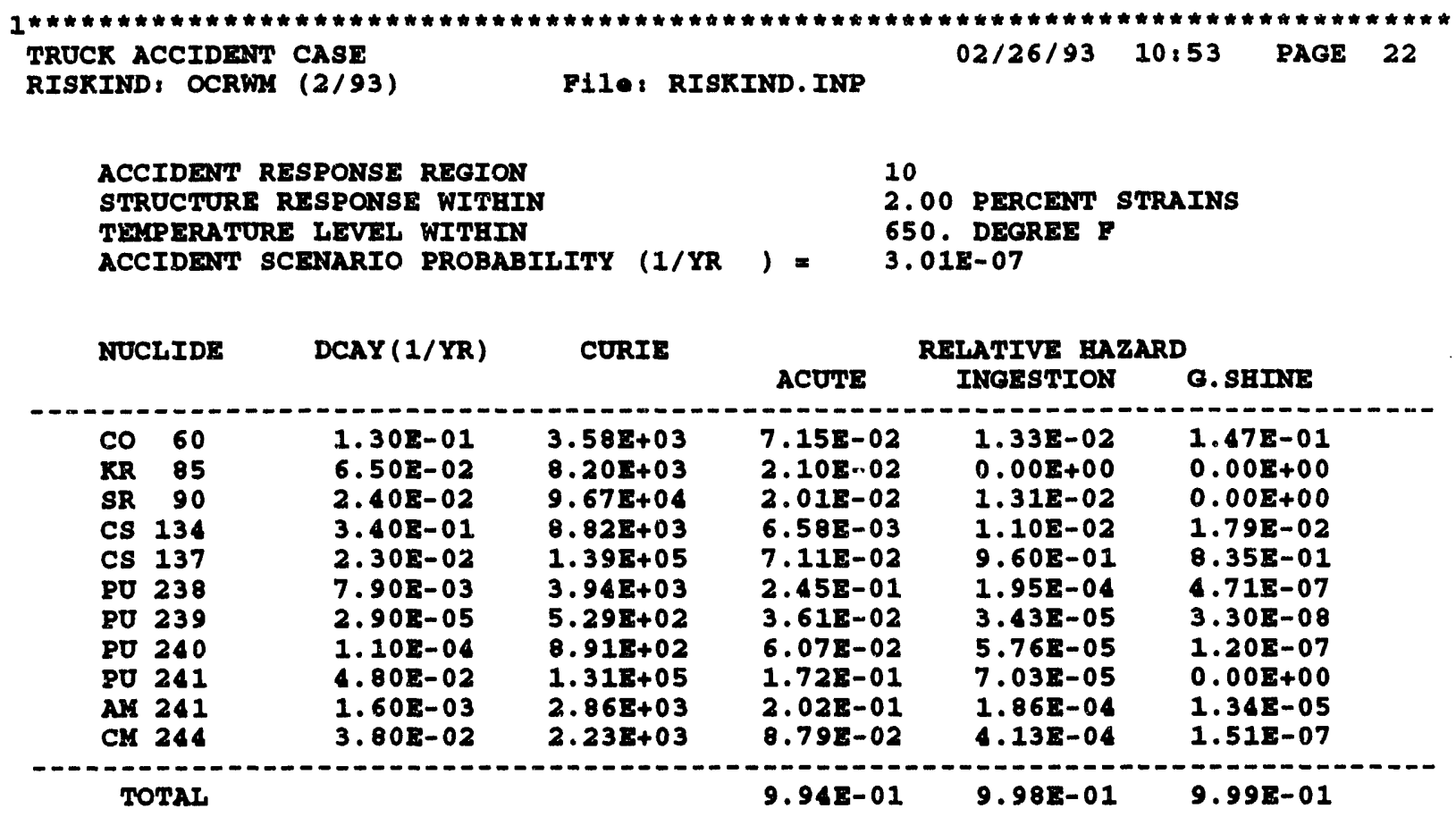




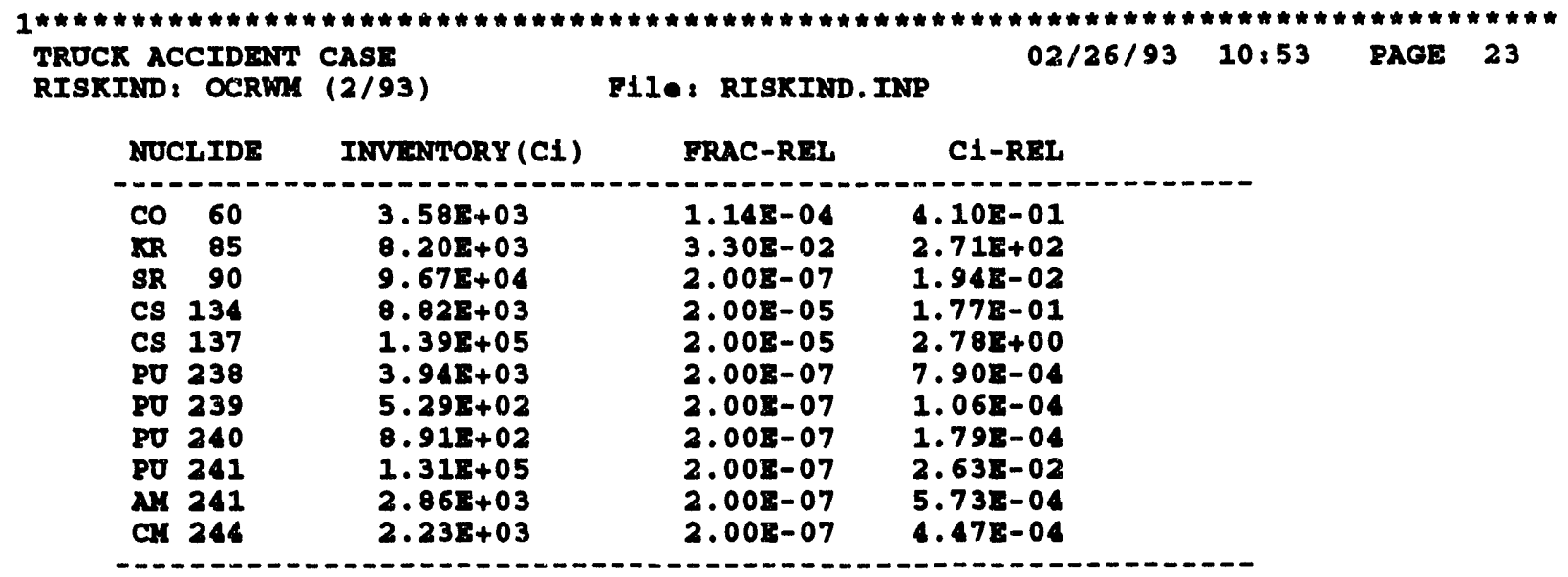

SUREAY OF POTENTIAL DOSE CONSEQUENCES

\begin{tabular}{|c|c|c|c|c|c|}
\hline I & LOCATION & $\mathrm{ACO}$ & ${ }_{A K}^{E D E}$ & TOTAI & EDE \\
\hline & WEATHER PERCENTILE & $50 \%$ & $95 \%$ & $50 \%$ & 95\% \\
\hline $\begin{array}{l}1 \\
2 \\
3 \\
4\end{array}$ & $\begin{array}{l}\text { Nearewt Resident } \\
\text { Nearest Cae station } \\
\text { Nearest School } \\
\text { Nearest Shopping Mal }\end{array}$ & $\begin{array}{l}4.28 z-02 \\
1.561-02 \\
1.10 z-01 \\
1.018-01\end{array}$ & $\begin{array}{l}2.73=-01 \\
2.19=-01 \\
1.70 z-01 \\
2.25 s-01\end{array}$ & $\begin{array}{l}4.28 z-02 \\
1.56 z-02 \\
1.10 z-01 \\
1.01 z-01\end{array}$ & $\begin{array}{l}2.73 z-01 \\
2.192-01 \\
1.702-01 \\
2.25=01\end{array}$ \\
\hline
\end{tabular}

\section{SUMARY OF POTENTIAL BHALTH CONSEOUHICES}

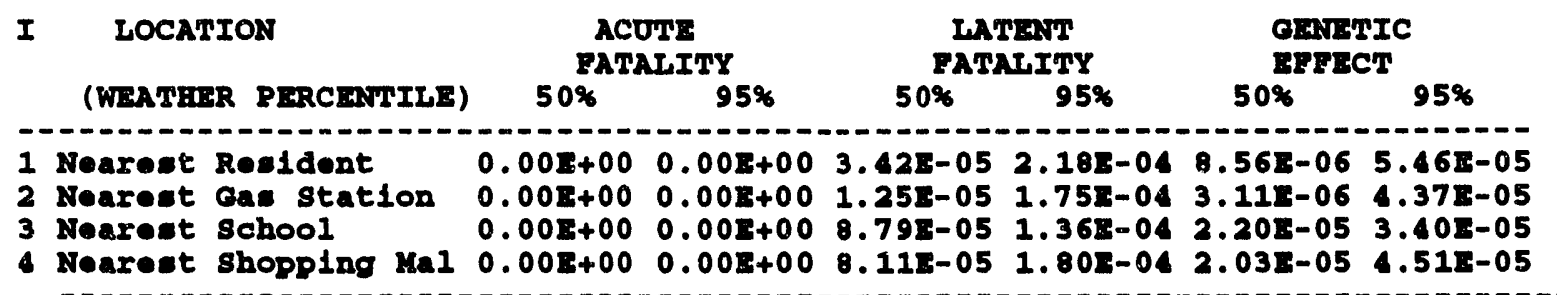




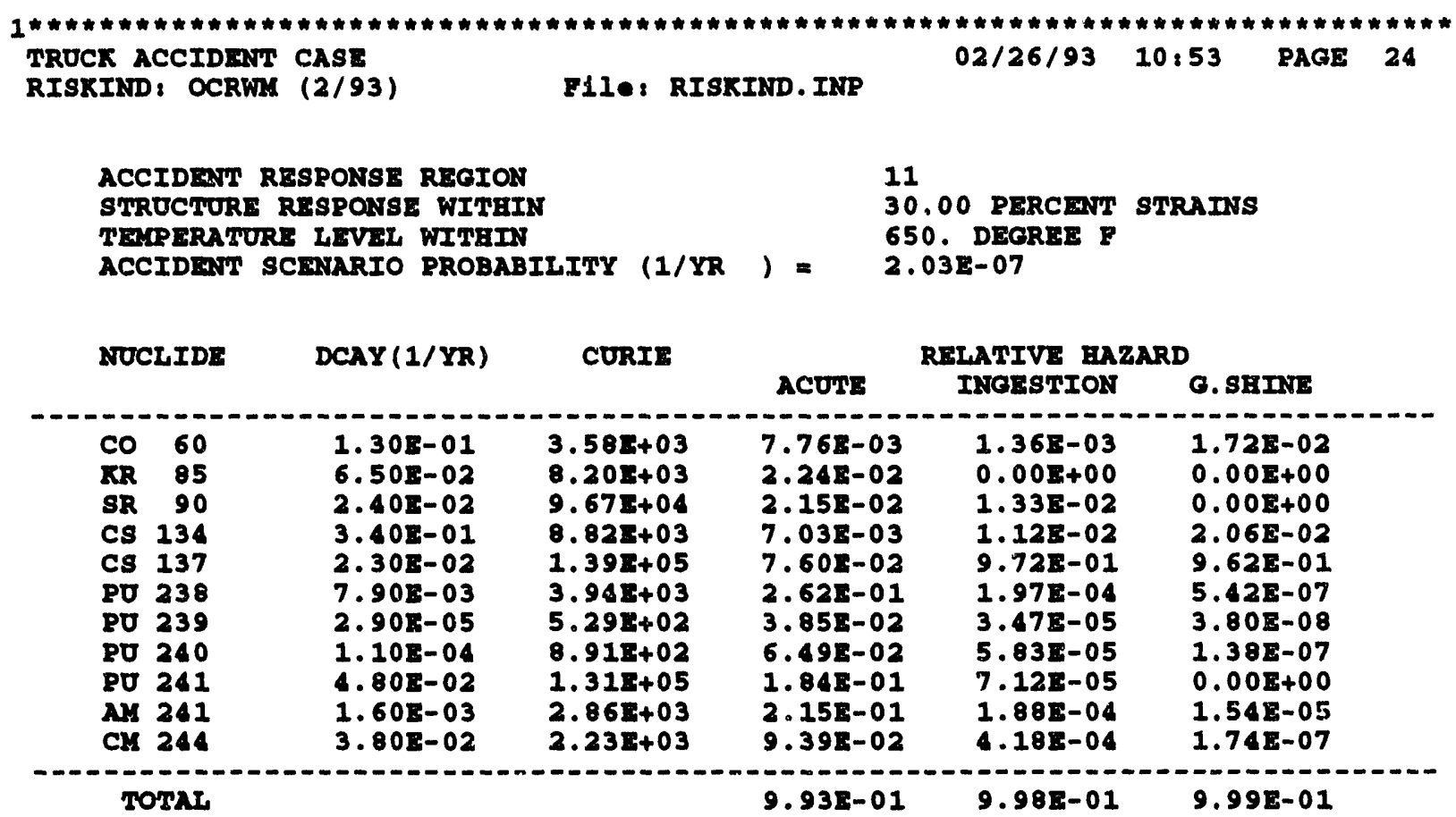




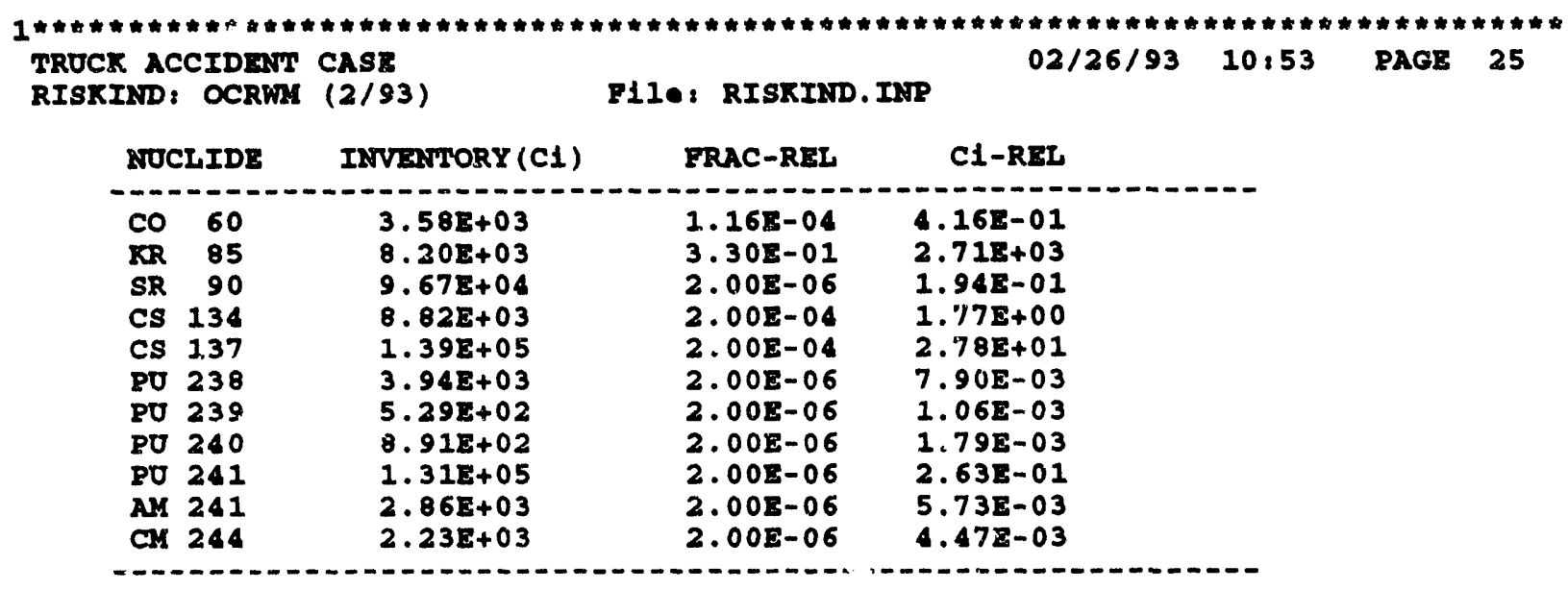

SOMRARY OF POTENTIAI DOSE CONSEOUENCES

\begin{tabular}{|c|c|c|c|c|c|}
\hline LOCAT & PION & $\mathrm{ACO}$ & EDE & TOSAL & RDE \\
\hline WEATHER & PERCENTILE & $50 \%$ & $95 \%$ & $50 \%$ & $95 \%$ \\
\hline $\begin{array}{l}\text { Nearest } \\
\text { Nearest } \\
\text { Noareet } \\
\text { Noareet }\end{array}$ & $\begin{array}{l}\text { Resident } \\
\text { Gas station } \\
\text { School } \\
\text { Shopplng Mal }\end{array}$ & $\begin{array}{l}4.012-01 \\
1.462-01 \\
1.03 E+00 \\
9.48 z-01\end{array}$ & $\begin{array}{l}2.55 z+00 \\
2.04 z+00 \\
1.59 z+00 \\
2.11 z+00\end{array}$ & $\begin{array}{l}4.012-01 \\
1.462-01 \\
1.032+00 \\
9.48 E-01\end{array}$ & $\begin{array}{l}2.55 z+00 \\
2.04 \Sigma+00 \\
1.59 z+00 \\
2.11 \Sigma+00\end{array}$ \\
\hline
\end{tabular}

SULARAY OF POTENTIA HEATTE CONSEQUHCES

I LOCATION

ACUTE FATALITY (WAATER PERCETILE) $50 \%$ $95 \%$

IATAT
EATAIITY
$0 \% \quad 95 \%$
GaterTC EREECT

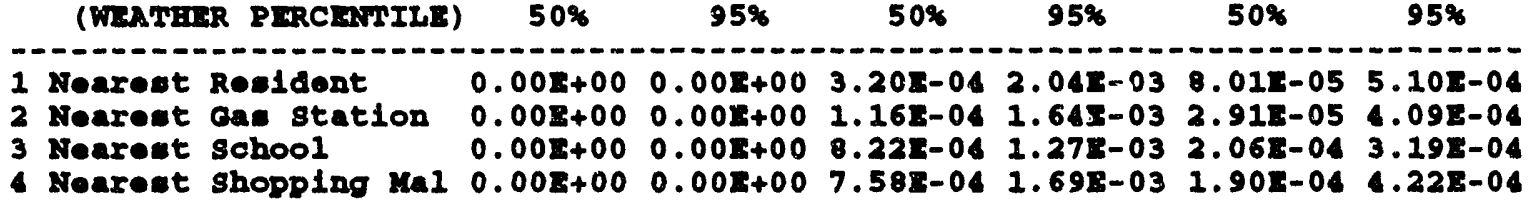
............... 


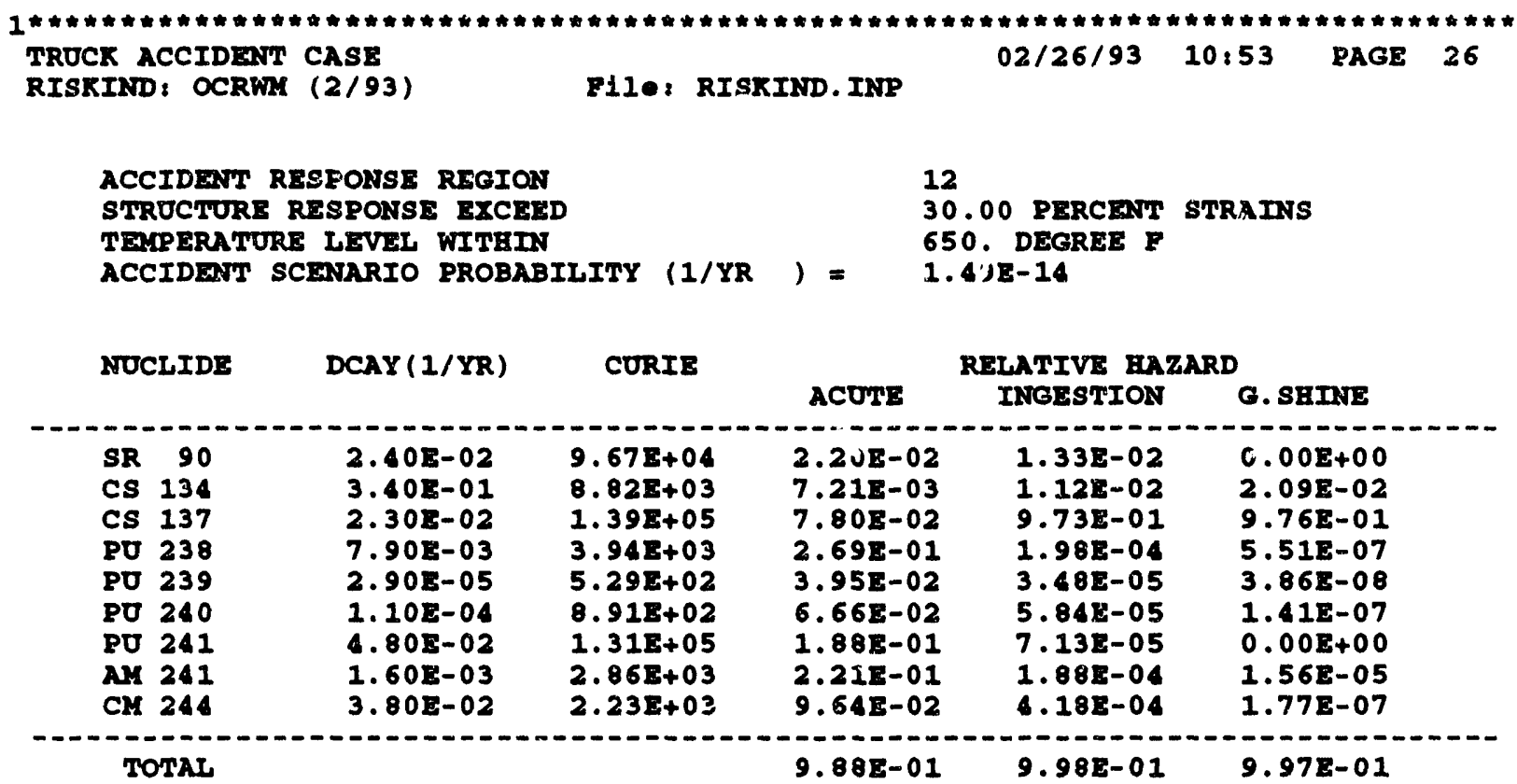




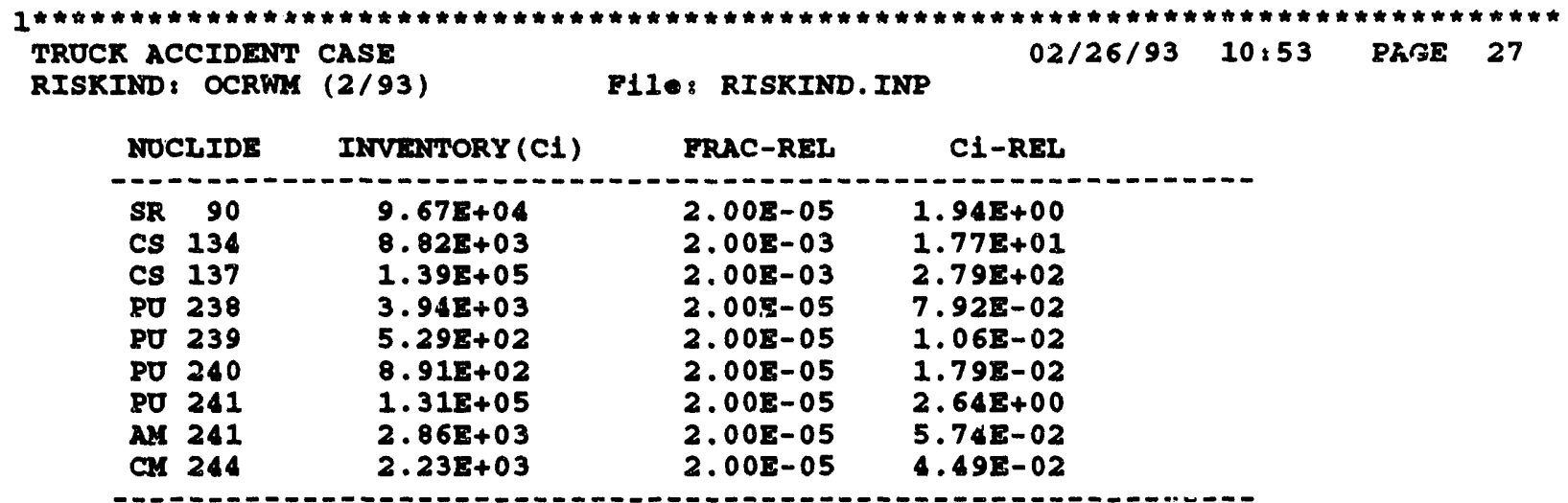

SUMAARY OF POTENTIAI DOSE CONSEQUENCES

\begin{tabular}{|c|c|c|c|c|c|c|}
\hline I & LOCAT & CON & $A C U$ & $\begin{array}{l}\text { EDE } \\
\text { ax }\end{array}$ & TOTA & $\mathbf{X}^{\mathbf{E D E}}$ \\
\hline & WEATEER I & ?ERCENYILE & $50 \%$ & $95 \%$ & $50 \%$ & $95 \%$ \\
\hline $\begin{array}{l}1 \\
2 \\
3 \\
4\end{array}$ & $\begin{array}{l}\text { Nearest } \\
\text { Nearest } \\
\text { Nearest } \\
\text { Nearest }\end{array}$ & $\begin{array}{l}\text { Residont } \\
\text { Gas station } \\
\text { School } \\
\text { Shopping Mal }\end{array}$ & $\begin{array}{l}3.89 \mathrm{E}+00 \\
1.42 \mathrm{E}+00 \\
9.99 \mathrm{E}+00 \\
9.21 \mathrm{E}+00\end{array}$ & $\begin{array}{l}2.48 \mathrm{E}+01 \\
1.99 \mathrm{E}+01 \\
1.55 \mathrm{E}+01 \\
2.05 \mathrm{E}+01\end{array}$ & $\begin{array}{l}3.89 \mathrm{E}+00 \\
1.42 \mathrm{E}+00 \\
9.99 \mathrm{E}+00 \\
9.21 \mathrm{E}+00\end{array}$ & $\begin{array}{l}2.48 E+01 \\
1.99 \mathrm{E}+01 \\
1.55 \mathrm{E}+01 \\
2.05 \mathrm{E}+01\end{array}$ \\
\hline
\end{tabular}

SULLARY OF POTENTIAL MEATTE CONSEQUEYCES

\begin{tabular}{|c|c|c|c|c|c|c|}
\hline LOCATION & $\begin{array}{r}\text { ACl } \\
\text { PAT }\end{array}$ & $\begin{array}{l}\text { TrE } \\
\text { LITY }\end{array}$ & $\begin{array}{r}\text { IAT } \\
\text { FAT }\end{array}$ & $\begin{array}{l}\mathrm{X} A \mathrm{NS} \\
\mathrm{IITY}\end{array}$ & $\begin{array}{l}\text { GENE } \\
\text { EFRE }\end{array}$ & $\begin{array}{l}\text { TIC } \\
\text { CT }\end{array}$ \\
\hline (WEATHER PERCENTILE) & $50 \%$ & $95 \%$ & $50 \%$ & $95 \%$ & $50 \%$ & $95 \%$ \\
\hline $\begin{array}{l}1 \text { Nearest Resident } \\
2 \text { Nearest Gas station } \\
3 \text { Nearest School } \\
4 \text { Nearest Shopping Mal }\end{array}$ & $\begin{array}{l}0.00 \mathrm{z}+00 \\
0.00 \mathrm{E}+00 \\
0.00 \mathrm{z}+00 \\
0.00 \mathrm{E}+00\end{array}$ & $\begin{array}{l}0.00 \mathrm{Z}+00 \\
0.00 \mathrm{Z}+00 \\
0.00 \mathrm{Z}+00 \\
0.00 \mathrm{E}+00\end{array}$ & $\begin{array}{l}3.11 z-03 \\
1.13 z-03 \\
7.99 z-03 \\
7.37 \mathrm{z}-03\end{array}$ & $\begin{array}{l}1.98 z-02 \\
1.59 z-02 \\
1.24 z-02 \\
1.64 z-02\end{array}$ & $\begin{array}{l}7.79 \mathrm{E}-04 \\
2.83 \mathrm{E}-04 \\
2.00 \mathrm{E}-03 \\
1.84 \mathrm{E}-03\end{array}$ & $\begin{array}{l}4.96 z-03 \\
3.97 z-03 \\
3.10 z-03 \\
4.10 z-03\end{array}$ \\
\hline
\end{tabular}

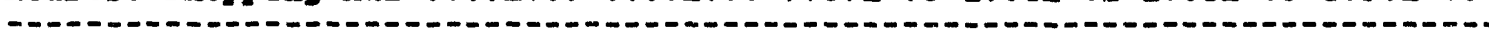




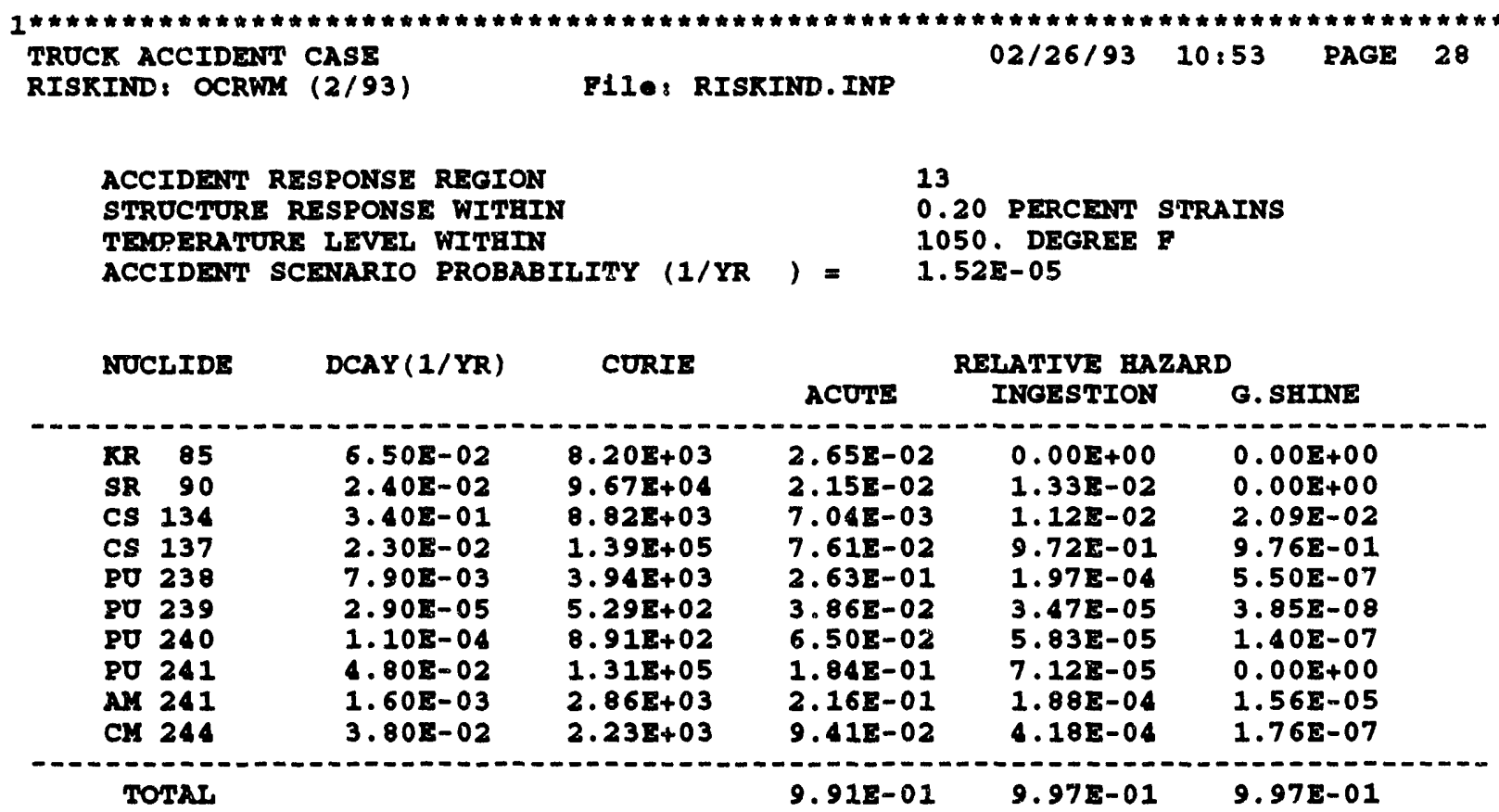




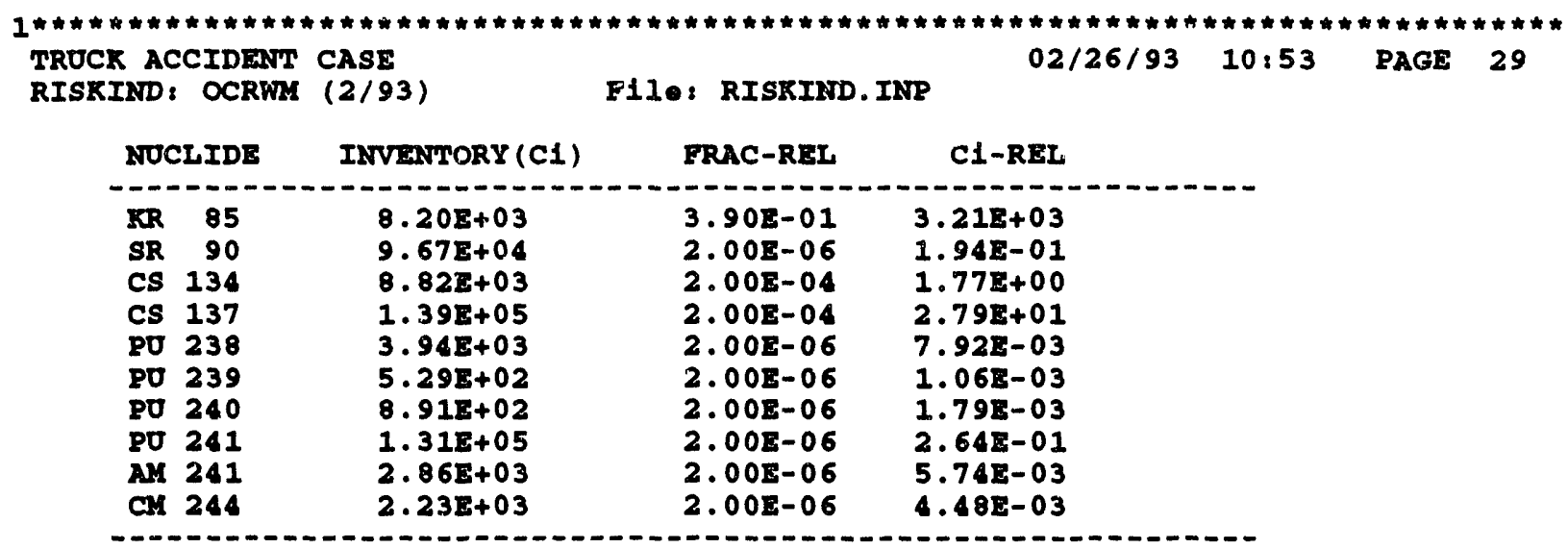

SUMRARY OF POTENTIAL DOSE CONSEQUENCES

\begin{tabular}{|c|c|c|c|c|c|}
\hline & LOCATION & ACO & EDE & TOTAI & EDE \\
\hline & VEATEER PERCEWTILE & $50 \%$ & $95 \%$ & $50 \%$ & $95 \%$ \\
\hline & $\begin{array}{l}\text { Nearest Resident } \\
\text { Neareat Gas station } \\
\text { Nearest school } \\
\text { Nearest shopping Mal }\end{array}$ & $\begin{array}{l}4.00 \mathrm{z}-01 \\
1.45 \mathrm{E}-01 \\
1.03 \mathrm{E}+00 \\
9.46 \mathrm{z}-01\end{array}$ & $\begin{array}{l}2.55 \mathrm{E}+00 \\
2.04 \mathrm{E}+00 \\
1.59 \mathrm{E}+00 \\
2.11 \mathrm{E}+00\end{array}$ & $\begin{array}{l}4.00 E-01 \\
1.45 E-01 \\
1.03 E+00 \\
9.46 E-01\end{array}$ & $\begin{array}{l}2 \cdot 55 \mathrm{E}+00 \\
2 \cdot 04 \mathrm{E}+00 \\
1.59 \mathrm{E}+00 \\
2 \cdot 11 \mathrm{E}+00\end{array}$ \\
\hline
\end{tabular}

SUMARY OF POTENTIAL BEALTE CONSEQUENCES

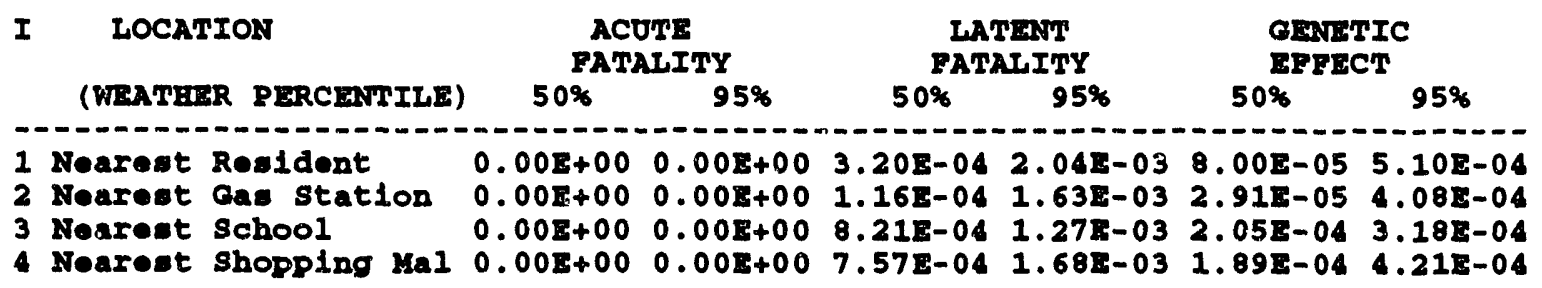




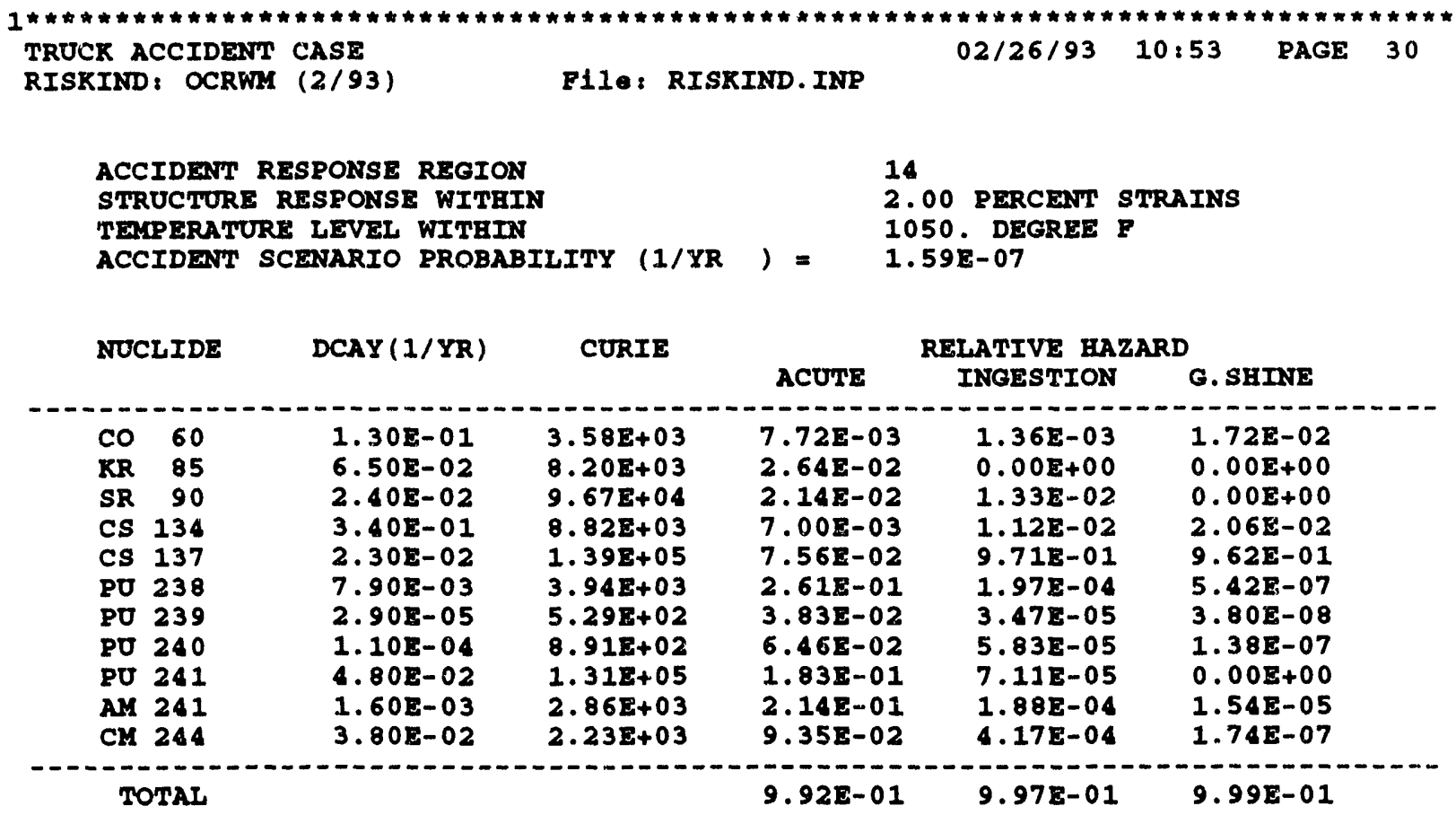




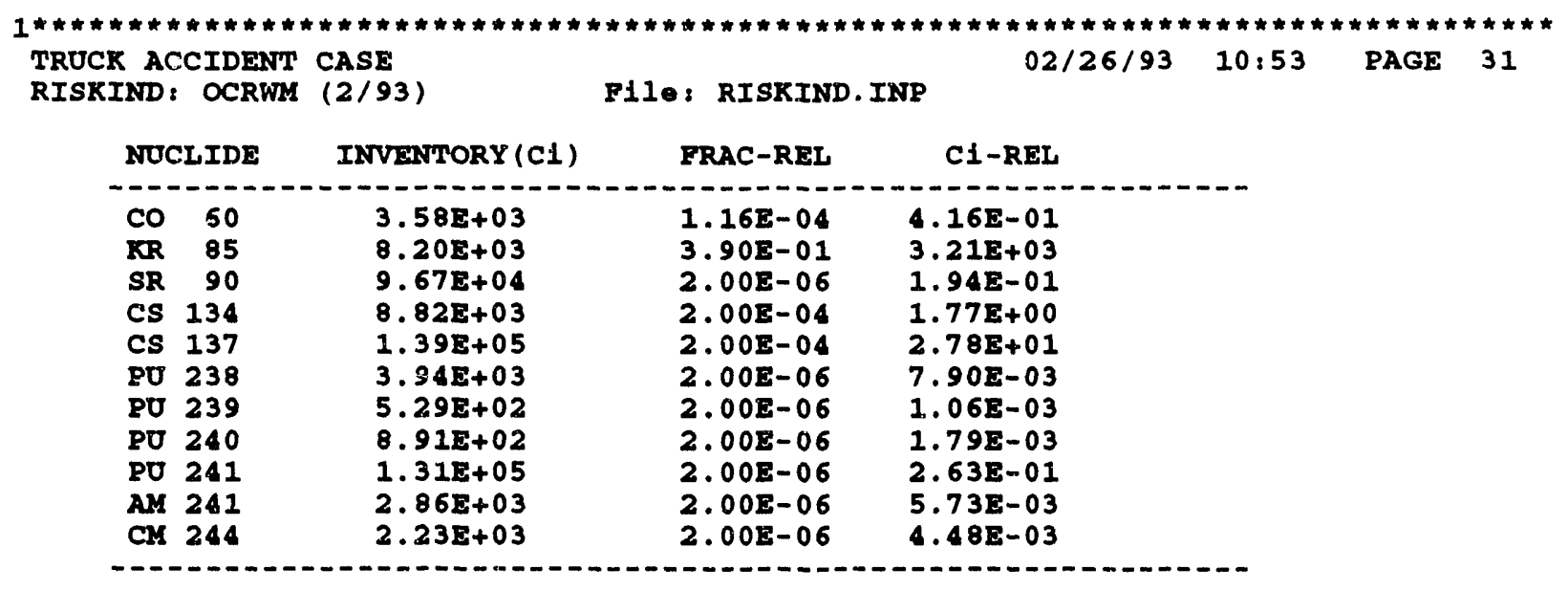

SULLARY OF POTENTIAL DOSE CONSEQUENCES

\begin{tabular}{|c|c|c|c|c|c|}
\hline LOCAT & IION & $A C O$ & $\begin{array}{l}3 \text { EDE } \\
\text { GX }\end{array}$ & TOTAI & EDE \\
\hline WEATHER & PERCENTILE & $50 \%$ & $95 \%$ & $50 \%$ & $95 \%$ \\
\hline $\begin{array}{ll}1 & \text { Nearest } \\
2 & \text { Nearest } \\
3 & \text { Nearest } \\
4 & \text { Nearest }\end{array}$ & $\begin{array}{l}\text { Resident } \\
\text { Gas station } \\
\text { School } \\
\text { Shopping Mal }\end{array}$ & $\begin{array}{l}4.02 \mathrm{E}-01 \\
1.46 \mathrm{E}-01 \\
1.03 \mathrm{E}+00 \\
9.52 \mathrm{E}-01\end{array}$ & $\begin{array}{l}2.56 \mathrm{E}+00 \\
2.05 \mathrm{E}+00 \\
1.60 \mathrm{E}+00 \\
2.12 \mathrm{E}+00\end{array}$ & $\begin{array}{l}4.02 \mathrm{E}-01 \\
1.46 \mathrm{E}-01 \\
1.03 \mathrm{E}+00 \\
9.52 \mathrm{E}-01\end{array}$ & $\begin{array}{l}2.56 \mathrm{E}+00 \\
2.05 \mathrm{E}+00 \\
1.60 \mathrm{E}+00 \\
2.12 \mathrm{E}+00\end{array}$ \\
\hline
\end{tabular}

SULARTY OF POTENTIAL BEATTE CONSEQUENCES

\begin{tabular}{|c|c|c|c|c|c|c|c|}
\hline \multirow[t]{2}{*}{ I } & LOCATION & \multicolumn{2}{|c|}{$\begin{array}{l}\text { ACUTE } \\
\text { FATALITY }\end{array}$} & \multicolumn{2}{|c|}{$\begin{array}{l}\text { IRTENT } \\
\text { EATALITY }\end{array}$} & \multicolumn{2}{|c|}{$\begin{array}{l}\text { GENETIC } \\
\text { EFEECT }\end{array}$} \\
\hline & (WEATHER PERCENTILE) & $50 \%$ & $95 \%$ & $50 \%$ & $95 \%$ & $50 \%$ & $95 \%$ \\
\hline & $\begin{array}{l}\text { Nearest Resident } \\
\text { Nearest Gas station } \\
\text { Nearest School } \\
\text { Nearest Shopplng Mal }\end{array}$ & $\begin{array}{l}0.00 \mathrm{E}+00 \\
0.00 \mathrm{E}+00 \\
0.00 \mathrm{E}+00 \\
0.00 \mathrm{E}+00\end{array}$ & $\begin{array}{l}0.00 \mathrm{E}+00 \\
0.00 \mathrm{E}+00 \\
0.00 \mathrm{E}+00 \\
0.00 \mathrm{E}+00\end{array}$ & $\begin{array}{l}3.22 \mathrm{E}-04 \\
1.17 \mathrm{E}-04 \\
8.26 \mathrm{E}-04 \\
7.62 \mathrm{E}-04\end{array}$ & $\begin{array}{l}2.05 \mathrm{E}-03 \\
1.64 \mathrm{E}-03 \\
1.28 \mathrm{E}-03 \\
1.70 \mathrm{E}-03\end{array}$ & $\begin{array}{l}8.05 z-05 \\
2.93 z-05 \\
2.06 z-04 \\
1.90 z-04\end{array}$ & $\begin{array}{l}5.13 \mathrm{E}-04 \\
4.11 \mathrm{E}-04 \\
3.20 \mathrm{E}-04 \\
4.24 \mathrm{E}-04\end{array}$ \\
\hline
\end{tabular}




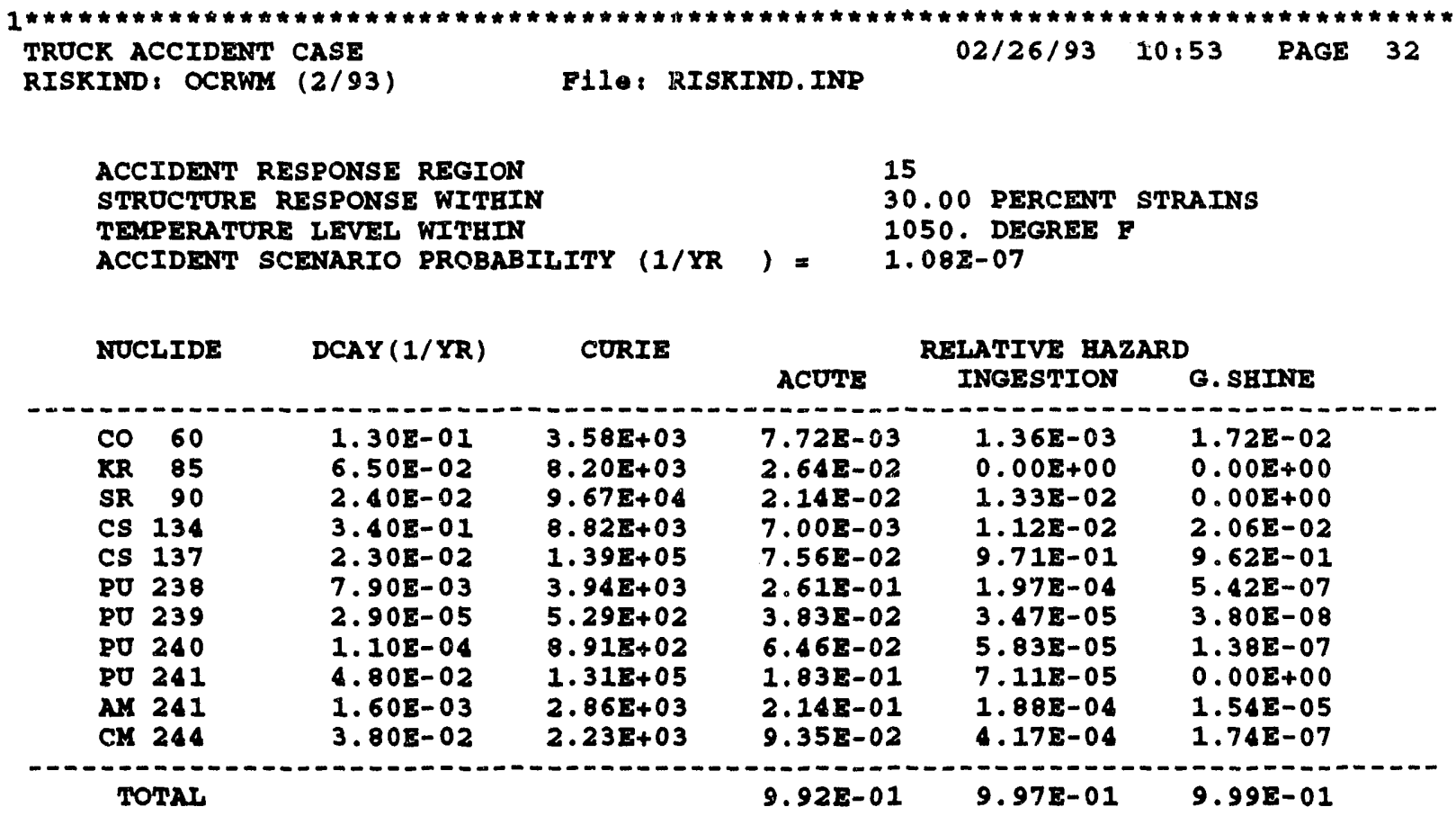




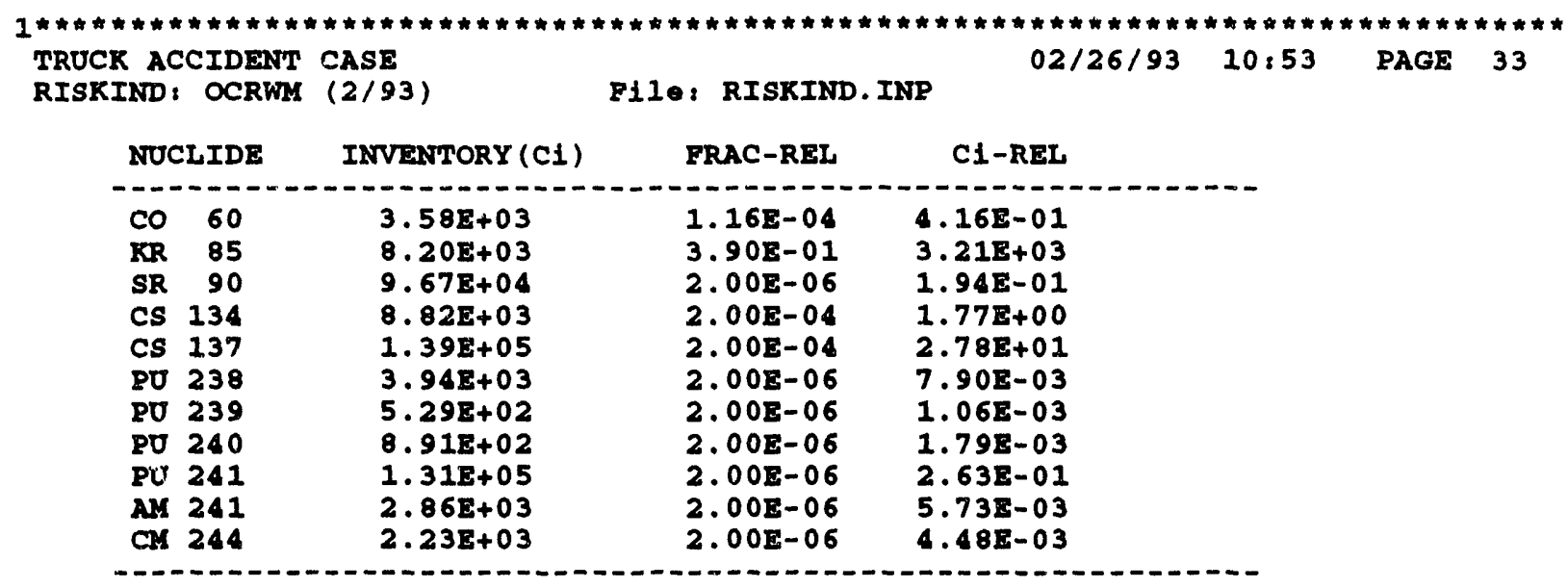

SUMARRY OF POTENTIAL DOSE CONSEOUENCES

\begin{tabular}{|c|c|c|c|c|c|}
\hline I & LOCATION & ACUI & EDE & $\begin{array}{r}\text { TOTAI } \\
R E\end{array}$ & EDE \\
\hline & NEATHER PERCENTILE & $50 \%$ & $95 \%$ & $50 \%$ & $95 \%$ \\
\hline 3 & $\begin{array}{l}\text { Nearect Resident } \\
\text { Nearest Gan station } \\
\text { Nearest school } \\
\text { Nearest shopping Mal }\end{array}$ & $\begin{array}{l}4.02 E-01 \\
1.46 E-01 \\
1.03 E+00 \\
9.52 E-01\end{array}$ & $\begin{array}{l}2.56 \mathrm{E}+00 \\
2.05 \mathrm{E}+00 \\
1.60 \mathrm{E}+00 \\
2.12 \mathrm{E}+00\end{array}$ & $\begin{array}{l}4.02 E-01 \\
1.46 E-01 \\
1.03 E+00 \\
9.52 E-01\end{array}$ & $\begin{array}{l}2.56 \mathrm{E}+00 \\
2.05 \mathrm{E}+00 \\
1.60 \mathrm{E}+00 \\
2.12 \mathrm{E}+00\end{array}$ \\
\hline
\end{tabular}

\section{SUMLARY OF POTENTIAL HEALTH CONSEOUENCES}

\begin{tabular}{|c|c|c|c|c|c|c|c|}
\hline & LOCATION & $\begin{array}{r}\text { ACl } \\
\text { FAT }\end{array}$ & $\begin{array}{l}\text { JTE } \\
\text { UITY }\end{array}$ & $\begin{array}{l}\text { ILA } \\
\text { EAT }\end{array}$ & $\begin{array}{l}\text { RENT } \\
\text { AITY }\end{array}$ & $\begin{array}{l}\text { GENEE } \\
\text { EEFEC }\end{array}$ & $\begin{array}{l}\text { IIC } \\
\text { CT }\end{array}$ \\
\hline & (WEATHERR PERCENTILE) & $50 \%$ & $95 \%$ & $50 \%$ & $95 \%$ & $50 \%$ & $95 \%$ \\
\hline & $\begin{array}{l}\text { Nearest Renident } \\
\text { Nearest Gas station } \\
\text { Nearest School } \\
\text { Neareet Shopping Mal }\end{array}$ & $\begin{array}{l}0.00 \mathrm{E}+00 \\
0.00 \mathrm{E}+00 \\
0.00 \mathrm{E}+00 \\
0.00 \mathrm{E}+00\end{array}$ & $\begin{array}{l}0.00 \mathrm{E}+00 \\
0.00 \mathrm{E}+00 \\
0.00 \mathrm{E}+00 \\
0.00 \mathrm{E}+00\end{array}$ & $\begin{array}{l}3.22 \mathrm{E}-04 \\
1.17 \mathrm{E}-04 \\
8.26 \mathrm{E}-04 \\
7.62 \mathrm{E}-04\end{array}$ & $\begin{array}{l}2.05 \mathrm{E}-03 \\
1.64 \mathrm{E}-03 \\
1.28 \mathrm{E}-03 \\
1.70 \mathrm{E}-03\end{array}$ & $\begin{array}{l}8.05 z-05 \\
2.93 z-05 \\
2.06 z-04 \\
1.90 z-04\end{array}$ & $\begin{array}{l}5.13 \mathrm{E}-04 \\
4.11 \mathrm{E}-04 \\
3.20 \mathrm{E}-04 \\
4.24 \mathrm{E}-04\end{array}$ \\
\hline
\end{tabular}




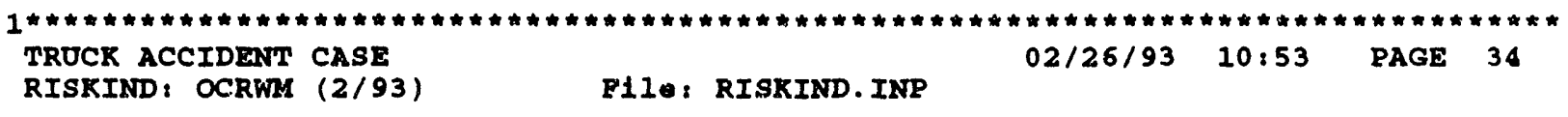

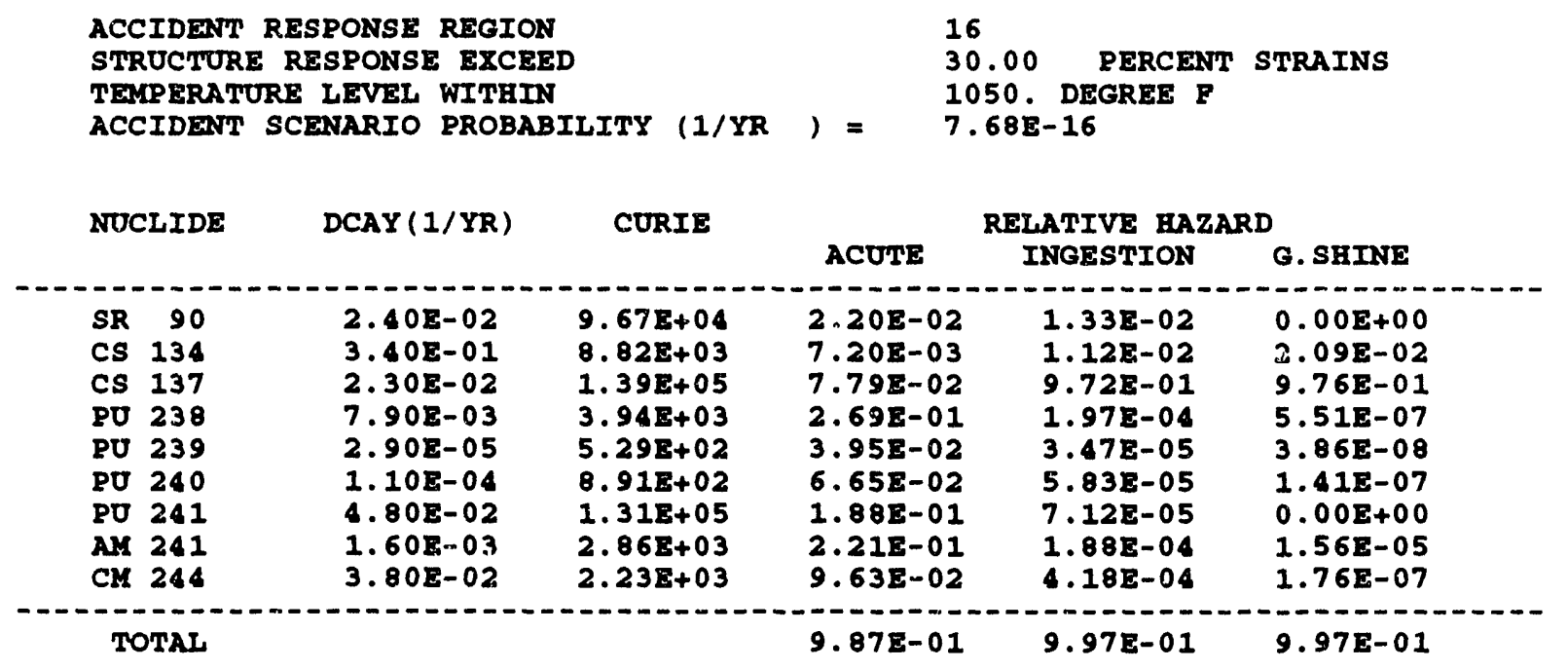




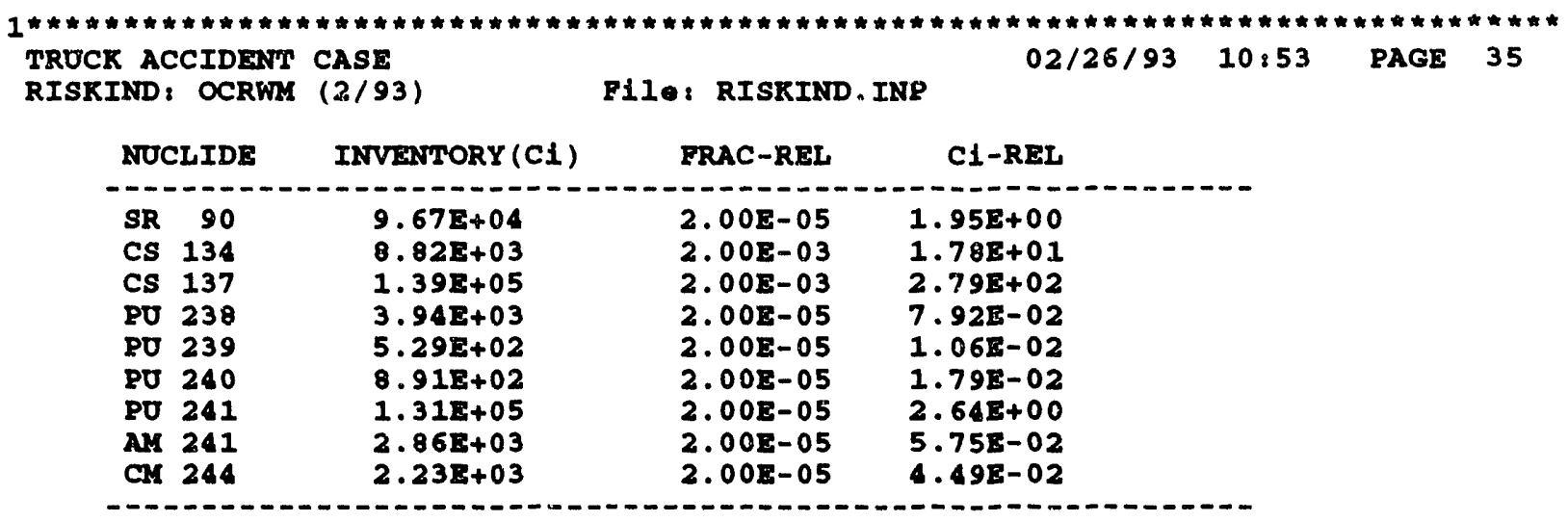

SULLARY OF POTENTIAI DOSE CONSEQUENCES

\begin{tabular}{|c|c|c|c|c|c|}
\hline I & LOCATION & $\mathrm{ACO}$ & EDE & $\begin{array}{r}\text { TOTA } \\
R\end{array}$ & $\mathbf{E D E}$ \\
\hline & WEATHER PERCENMITIE & $50 \%$ & $95 \%$ & $50 \%$ & $95 \%$ \\
\hline 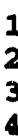 & $\begin{array}{l}\text { Nearest Resident } \\
\text { Nearest Gas station } \\
\text { Nearest School } \\
\text { Nearest Shopplng Mal }\end{array}$ & $\begin{array}{l}3 \cdot 90 z+00 \\
1 \cdot 42 E+00 \\
9 \cdot 99 E+00 \\
9 \cdot 22 E+00\end{array}$ & $\begin{array}{l}2.48 E+01 \\
1.99 z+01 \\
1.55 E+01 \\
2.05 E+01\end{array}$ & $\begin{array}{l}3.90 \mathrm{E}+00 \\
1.42 \mathrm{E}+00 \\
9.99 \mathrm{E}+00 \\
9.22 \mathrm{0}+00\end{array}$ & $\begin{array}{l}2 \cdot 48 E+01 \\
1 \cdot 998+01 \\
1.55 E+01 \\
2 \cdot 058+01\end{array}$ \\
\hline
\end{tabular}

SUMLARY OE POTENTIAI HEALTH CONSEOUENCES

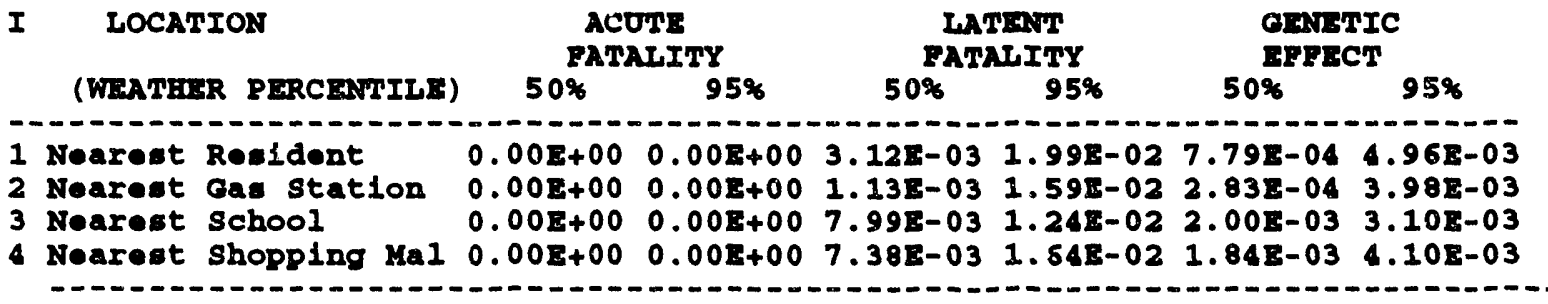




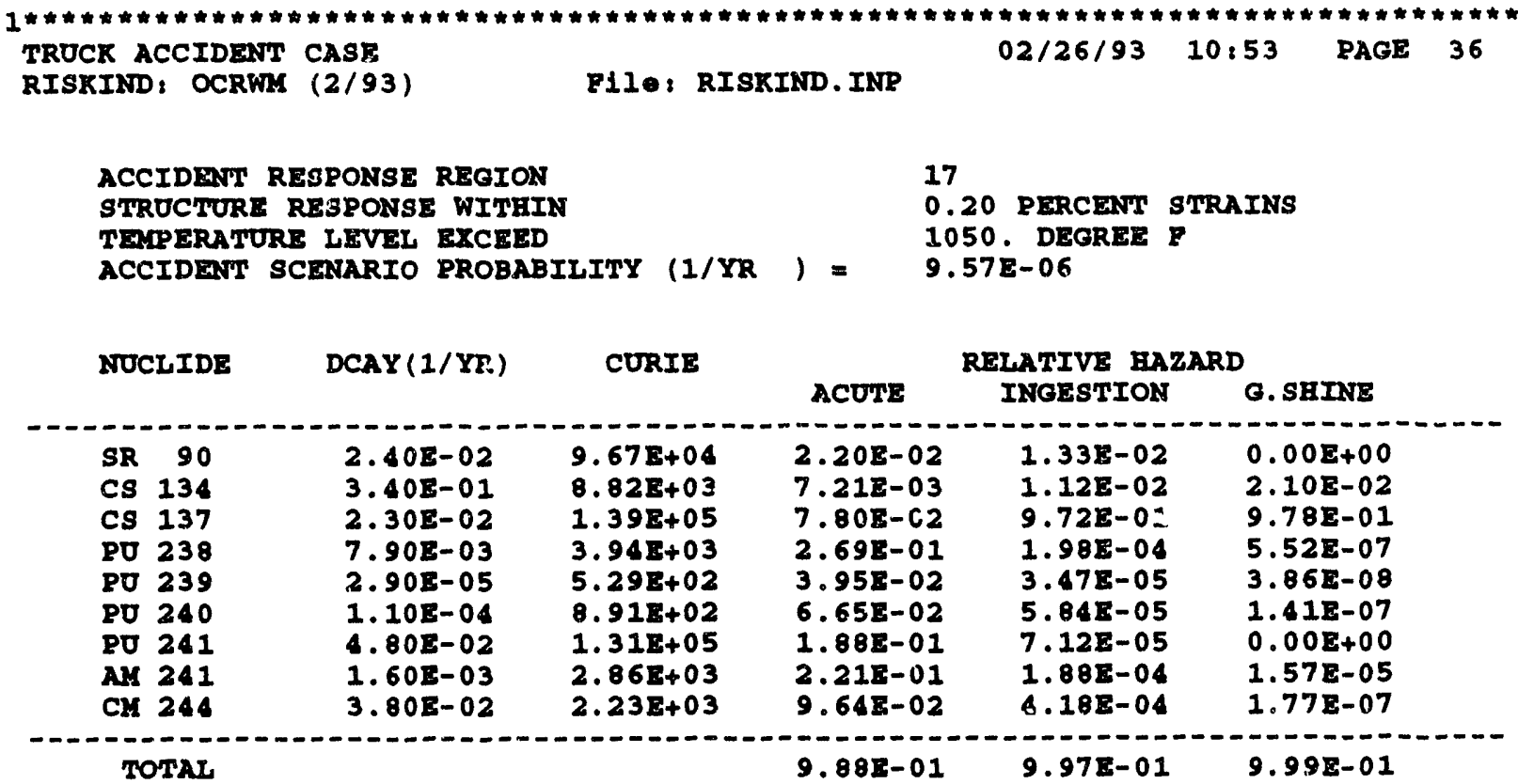




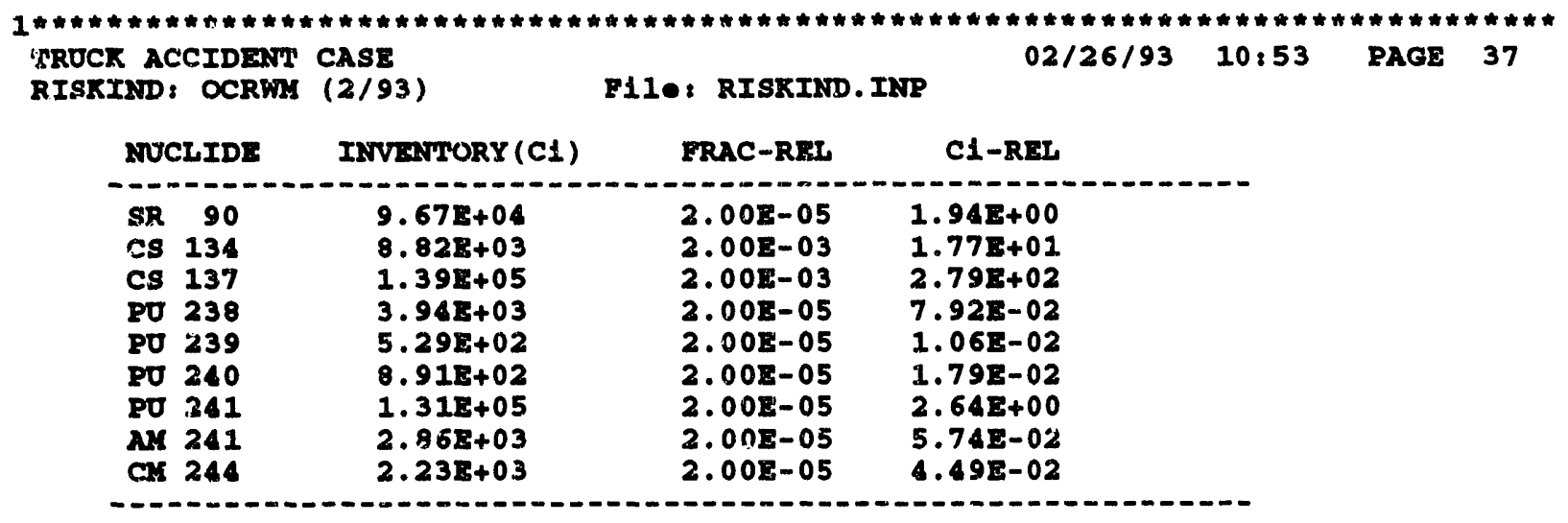

SUMDARY OF POTWWIAL DOSE CONSEQUEYCES

\begin{tabular}{|c|c|c|c|c|c|}
\hline LOCAT & ION & $\mathrm{ACO}$ & Ars & $\begin{array}{r}\text { TOTAI } \\
\mathrm{RE}\end{array}$ & EDE \\
\hline MEATEER & PERCENTILE & $50 \%$ & $95 \%$ & $50 \%$ & $95 \%$ \\
\hline $\begin{array}{ll}1 & \text { Nearest } \\
2 & \text { Nearent } \\
3 & \text { Nearest } \\
4 & \text { Nearost }\end{array}$ & $\begin{array}{l}\text { Rosident } \\
\text { Cas station } \\
\text { School } \\
\text { Shopplng } \mathrm{Mal}\end{array}$ & $\begin{array}{l}3.89 z+00 \\
1.42 \mathrm{E}+00 \\
9.99 \mathrm{E}+00 \\
9.21 \mathrm{E}+00\end{array}$ & $\begin{array}{l}2.482+01 \\
1.998+01 \\
1.55 \mathrm{z}+01 \\
2.052+01\end{array}$ & $\begin{array}{l}3.89 \mathrm{E}+00 \\
1.42 \mathrm{E}+00 \\
9.99 \mathrm{E}+00 \\
9.21 \mathrm{E}+00\end{array}$ & $\begin{array}{l}2.48 E+01 \\
1.99 \mathrm{E}+01 \\
1.55 \mathrm{E}+01 \\
2.05 \mathrm{E}+01\end{array}$ \\
\hline
\end{tabular}

SOLARAY OF POTENTIAI BEALTH CONSEQUETCES

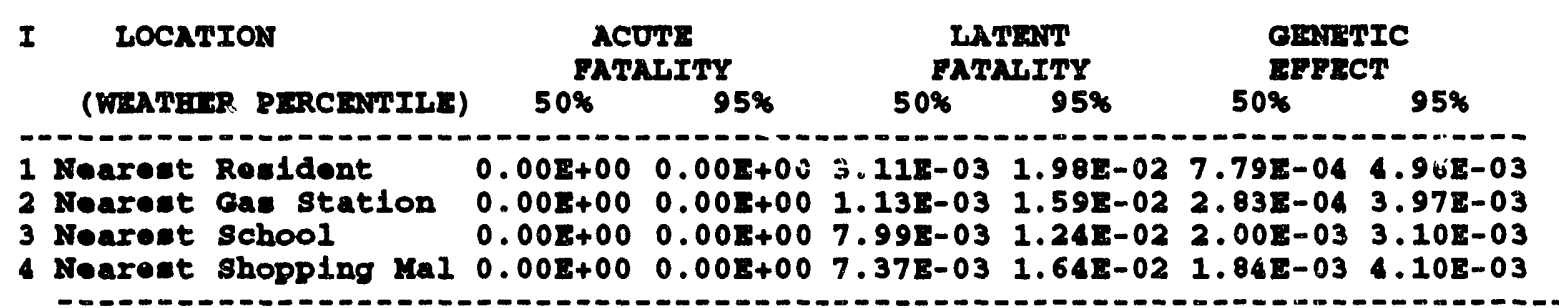




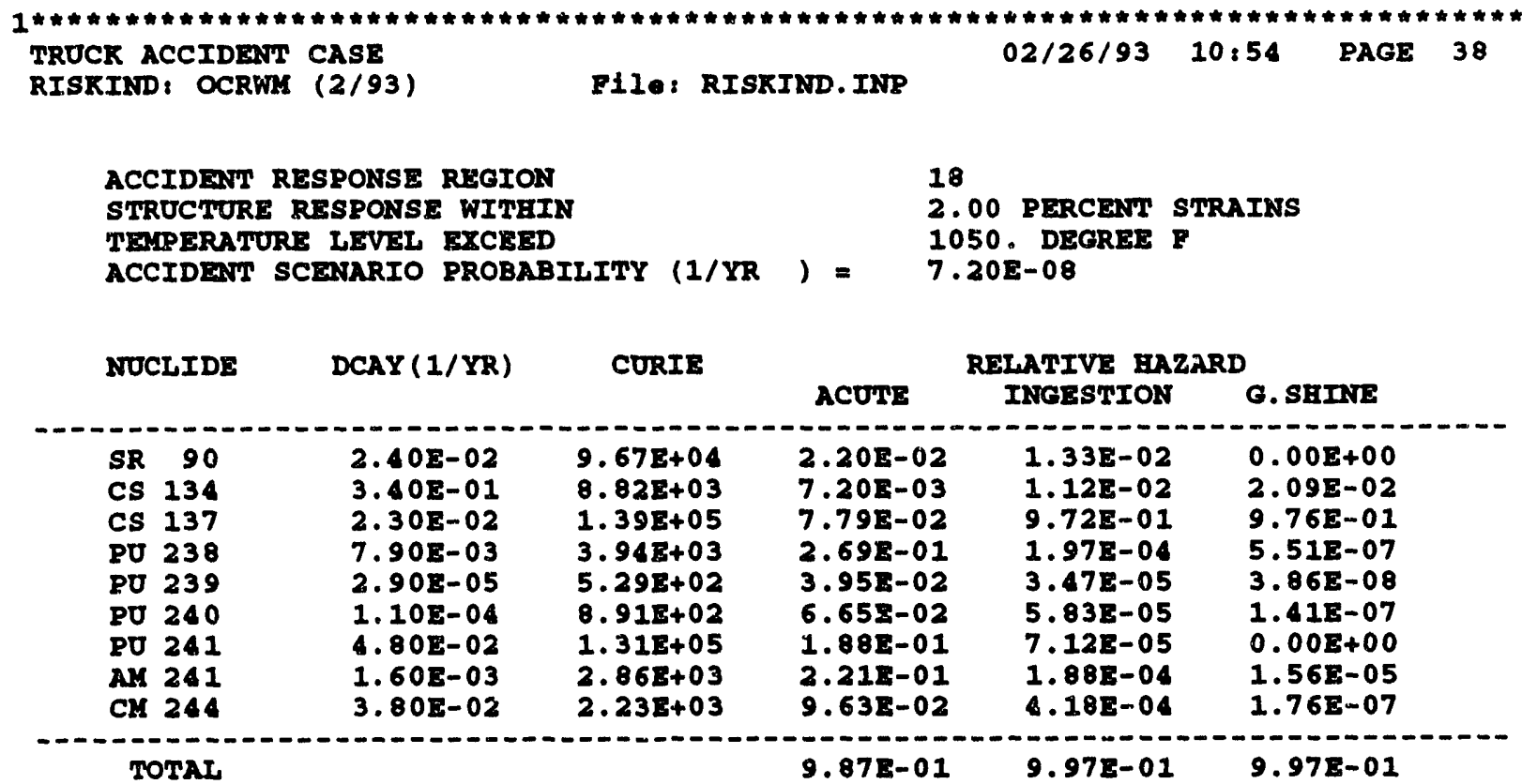




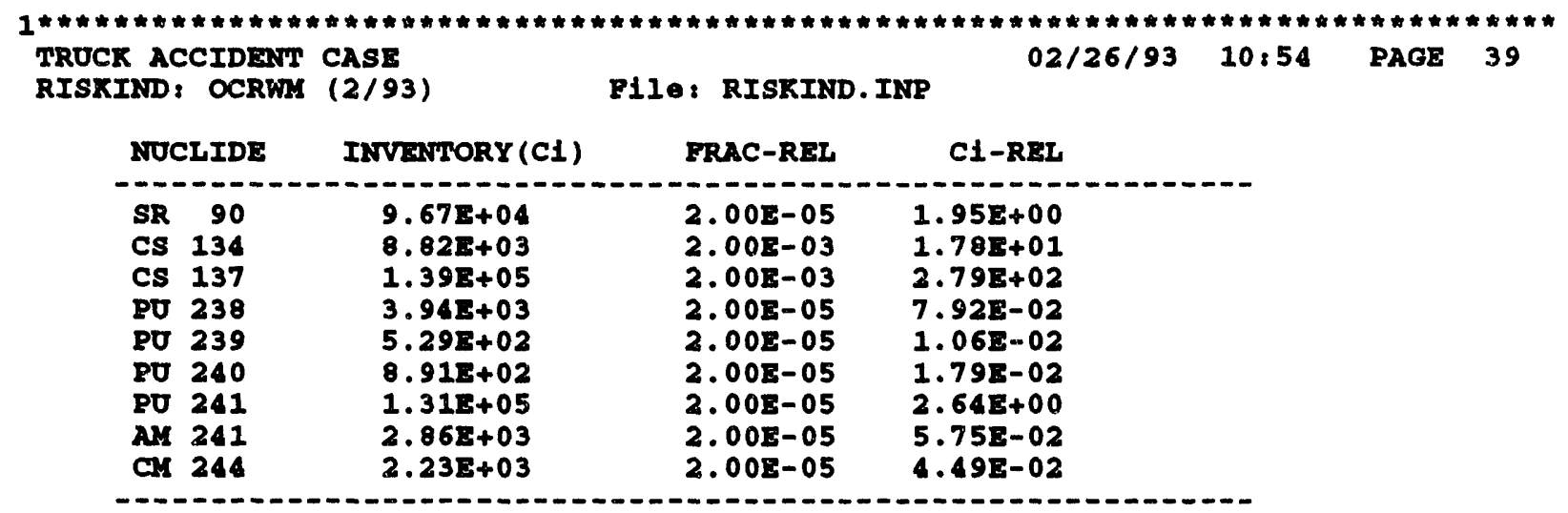

SOMDARY OF POTENTIAL DOSE CONSEQUENCES

\begin{tabular}{|c|c|c|c|c|c|c|}
\hline I & LOCAT & ION & $\mathrm{ACO}$ & $\begin{array}{l}\text { EDE } \\
\text { Ex }\end{array}$ & TOTA & $\mathbf{E D E}$ \\
\hline & NEATERR & PERCENTILE & $50 \%$ & $95 \%$ & $50 \%$ & $95 \%$ \\
\hline $\begin{array}{l}1 \\
2 \\
3 \\
4\end{array}$ & $\begin{array}{l}\text { Nearest } \\
\text { Noarest } \\
\text { Nearest } \\
\text { Nearest }\end{array}$ & $\begin{array}{l}\text { Rosident } \\
\text { Gas station } \\
\text { school } \\
\text { shopping Mal }\end{array}$ & $\begin{array}{l}3.90 z+00 \\
1.42 z+00 \\
9.99 z+00 \\
9.22 E+00\end{array}$ & $\begin{array}{l}2.485+01 \\
1.995+01 \\
1.55 z+01 \\
2.05 E+01\end{array}$ & $\begin{array}{l}3.90 z+00 \\
1.42 E+00 \\
9.99 z+00 \\
9.228+00\end{array}$ & $\begin{array}{l}2.48 E+01 \\
1.99 E+01 \\
1.55 E+01 \\
2.05 E+01\end{array}$ \\
\hline
\end{tabular}

SULEARY OF POTENTIAT EEALTE CONSEQUEMCES

I LOCATION (WEATHER PERCENTILE)
ACUTE

FATALITY

(WEATHER PERCENIILE)
1 Nearest Resident
2 Nearest Gas station
3 Nearest School

$50 \%$

95\%

$0.00 \mathrm{E}+00 \quad 0.00 \mathrm{E}+00 \quad 3.12 \mathrm{E}-03 \quad 1.99 \mathrm{E}-02 \quad 7.79 \mathrm{E}-04 \quad 4.96 \mathrm{E}-03$

$0.00 \mathrm{E}+00 \quad 0.00 \mathrm{E}+00 \quad 1.13 \mathrm{E}-03 \quad 1.59 \mathrm{z}-02 \quad 2.83 \mathrm{E}-04 \quad 3.98 \mathrm{E}-03$

$0.00 \mathrm{E}+00 \quad 0.00 \mathrm{z}+00 \quad 7.99 \mathrm{E}-03 \quad 1.24 \mathrm{E}-02 \quad 2.00 \mathrm{z}-03 \quad 3.10 \mathrm{E}-03$

4 Nearest Shopping Mal $0.00 \mathrm{E}+00$ 0.00E+00 7.38E-03 1.64z-02 $1.84 \mathrm{E}-03 \quad 1.10 \mathrm{E}-03$ 


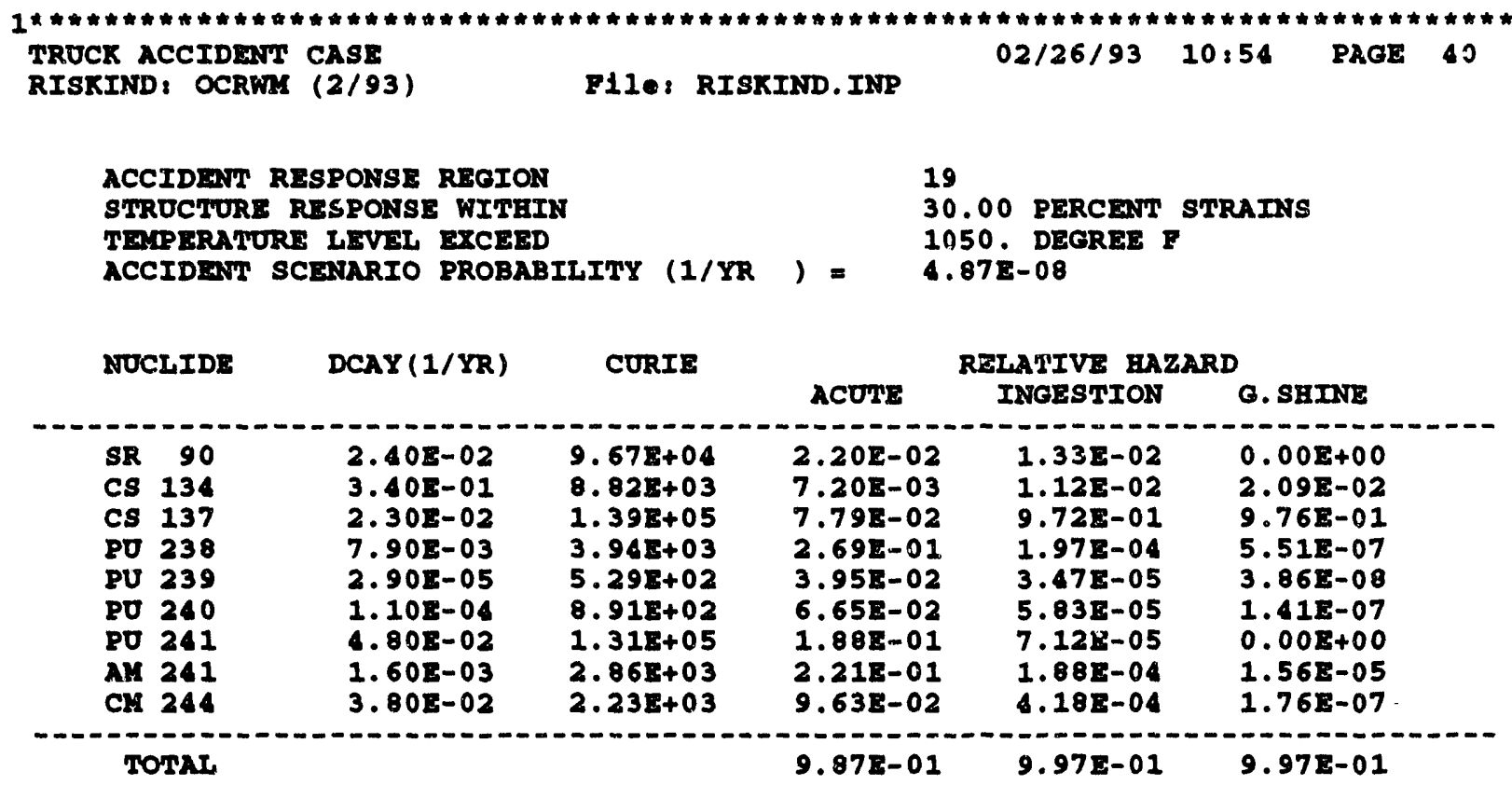




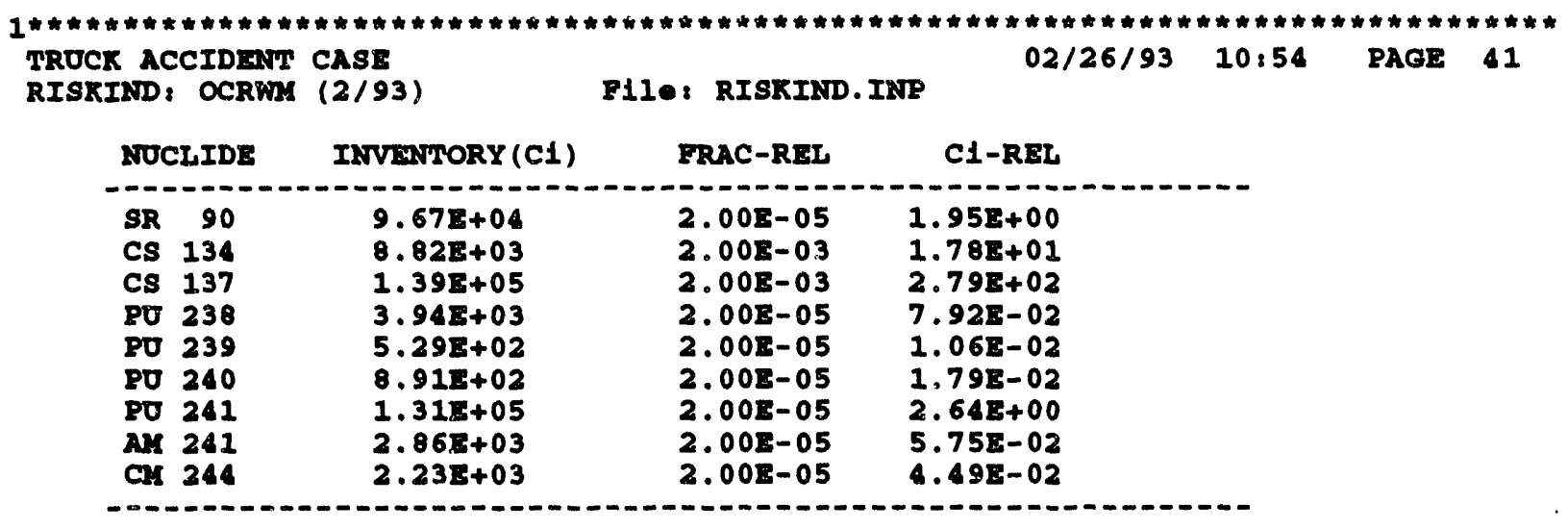

SURARRY OF POTEATIAI DOSE CONSEQUEATES

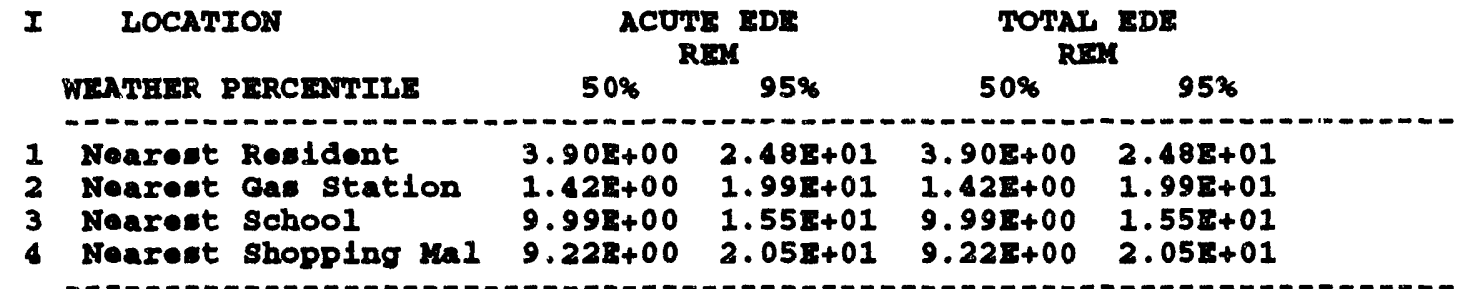

SULARRY OF POTENTIAI HEALTH CONSEOUENCES

I LOCATION (WEATEER PERCENTILE)
ACOT:

EATALITY

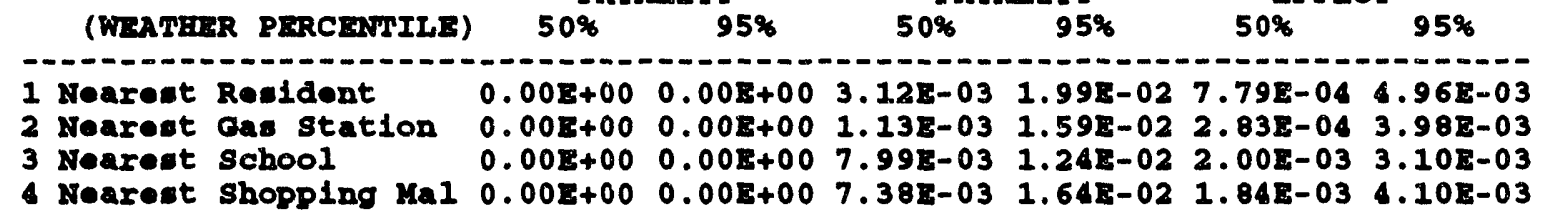




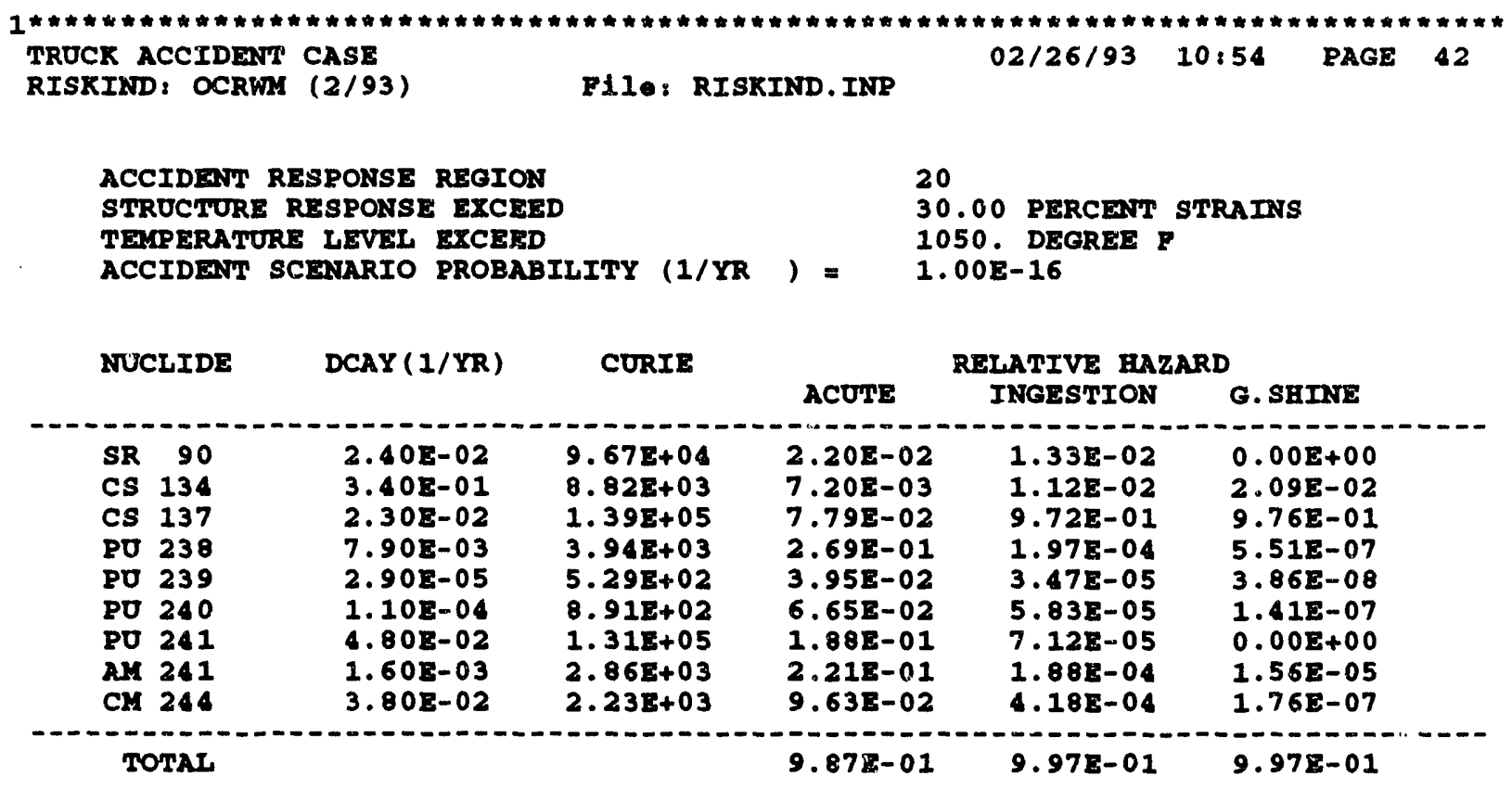




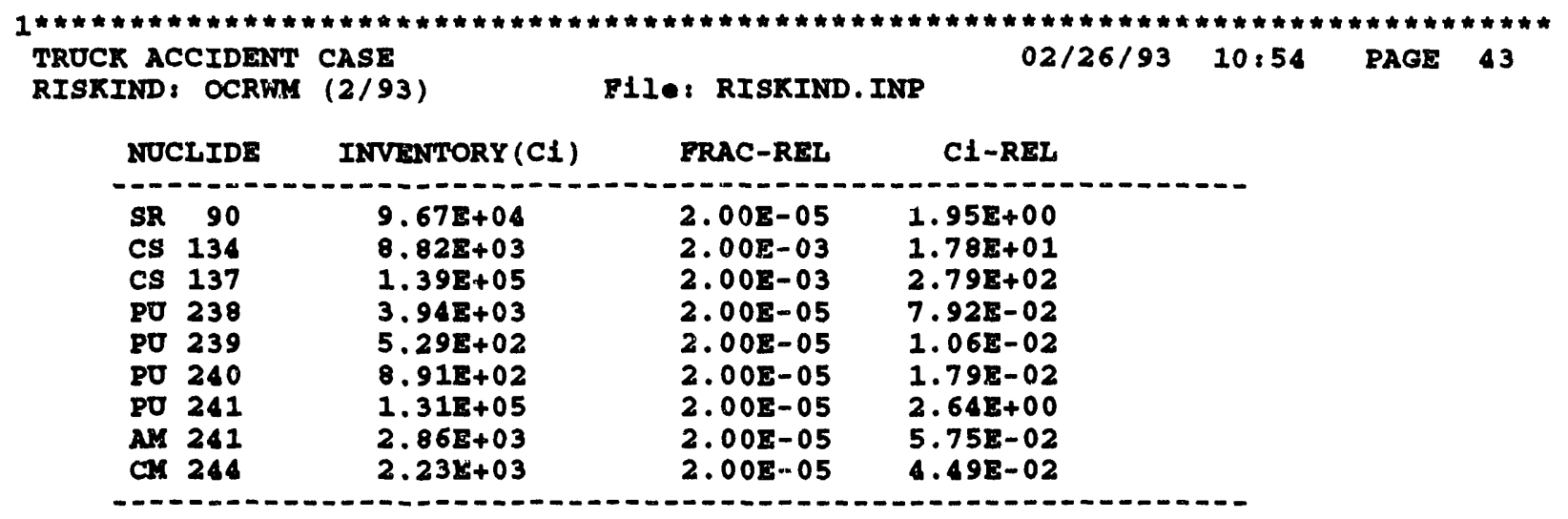

SUMAARY OF POTENTIAL DOSE CONSEQUENCES

\begin{tabular}{|c|c|c|c|c|c|}
\hline LOCAT & ION & $\mathrm{ACO}$ & EDE & $\begin{array}{r}\text { TOTA } \\
\mathbf{R}\end{array}$ & EDE \\
\hline WEATHER & PERCENTILE & $50 \%$ & $95 \%$ & $50 \%$ & $95 \%$ \\
\hline $\begin{array}{ll}1 & \text { Nearest } \\
2 & \text { Nearest } \\
3 & \text { Nearest } \\
4 & \text { Nearest }\end{array}$ & $\begin{array}{l}\text { Resident } \\
\text { Gas station } \\
\text { School } \\
\text { shopplng Mal }\end{array}$ & $\begin{array}{l}3.90 \mathrm{E}+00 \\
1.42 \mathrm{E}+00 \\
9.99 \mathrm{z}+00 \\
9.22 \mathrm{E}+00\end{array}$ & $\begin{array}{l}2.48 \mathrm{E}+01 \\
1.99 \mathrm{E}+01 \\
1.55 \mathrm{E}+01 \\
2.05 \mathrm{E}+01\end{array}$ & $\begin{array}{l}3.90 \mathrm{E}+00 \\
1.42 \mathrm{E}+00 \\
9.99 \mathrm{E}+00 \\
9.22 \mathrm{E}+00\end{array}$ & $\begin{array}{l}2.48 E+01 \\
1.99 E+01 \\
1.55 E+01 \\
2.05 E+01\end{array}$ \\
\hline
\end{tabular}

SUMLARY OF POTENTIAL MEALTH CONSEQUENCES

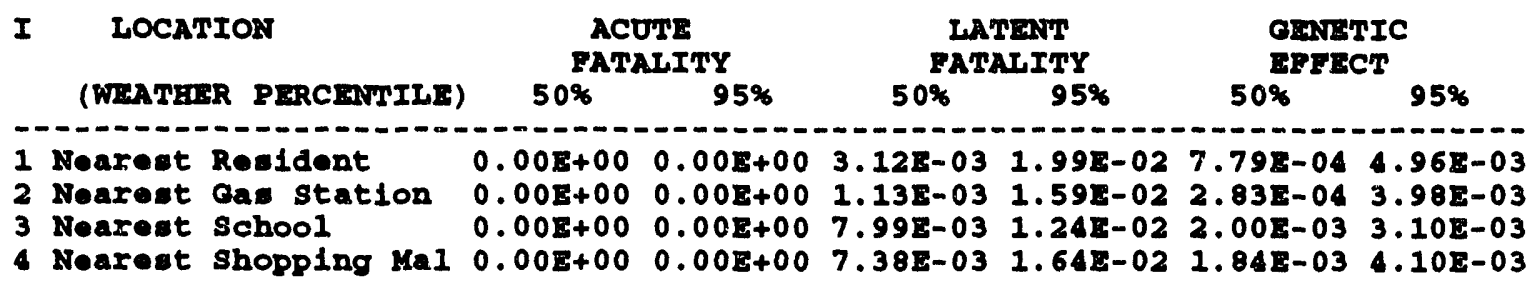

SOLDLRY PROBABILITY WEIGETED DOSE RISKS

(95\% WEATEER)

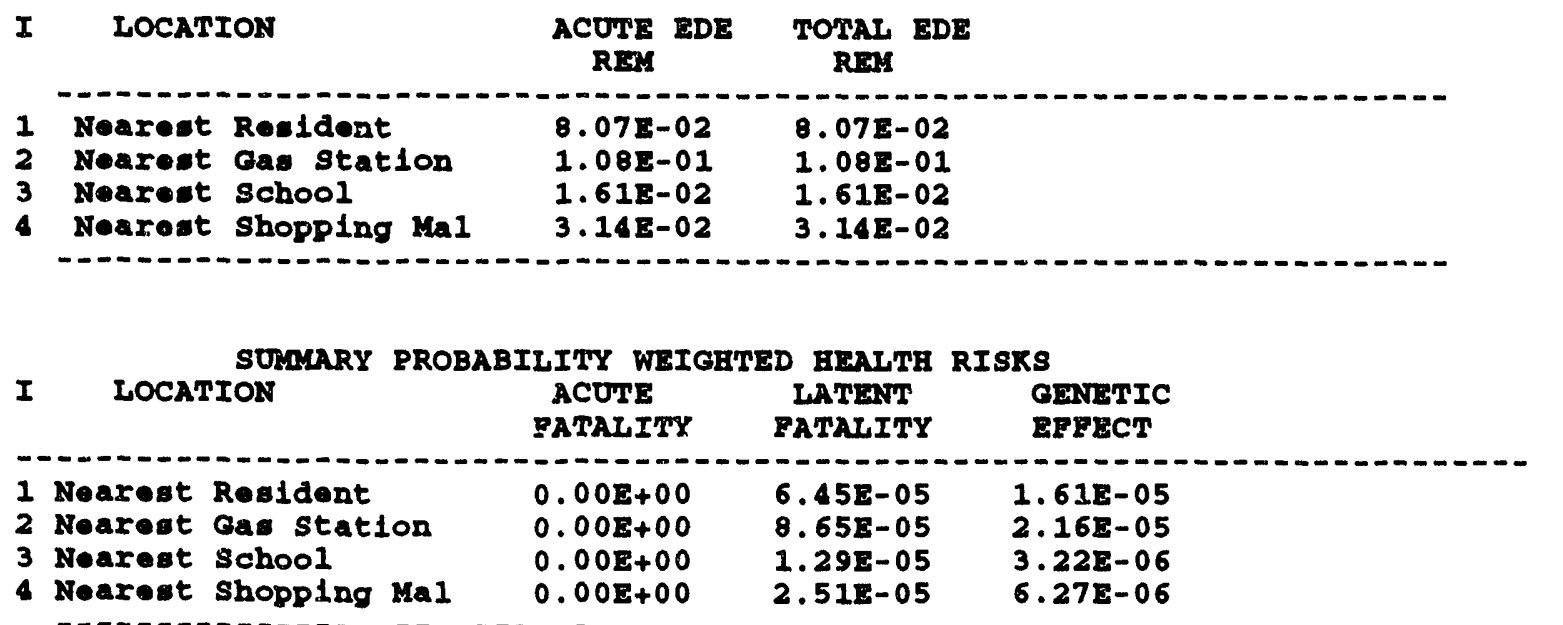




\section{APPENDIX H REFERENCE}

Lawrence Livermore National Laboratory, 1987, Shipping Container Response to Severe Highway and Railway Accident Conditions, NUREG/CR-4829, UCID-20733, prepared for U.S. Nuclear Regulatory Commission, Feb. 
DISTRIBUTION FOR ANL/EAIS-6, Rev. 0

\section{Internal}

ANL Patent Department

K.S. Macal (6)

ANL Technical Publications Services

S.Y. Chen (302)

\section{External}

U.S. Department of Energy Office of Scientific and Technical Information (12) Manager, U.S. Department of Energy Chicago Field Office

ANL-E Libraries

ANL-W Library 

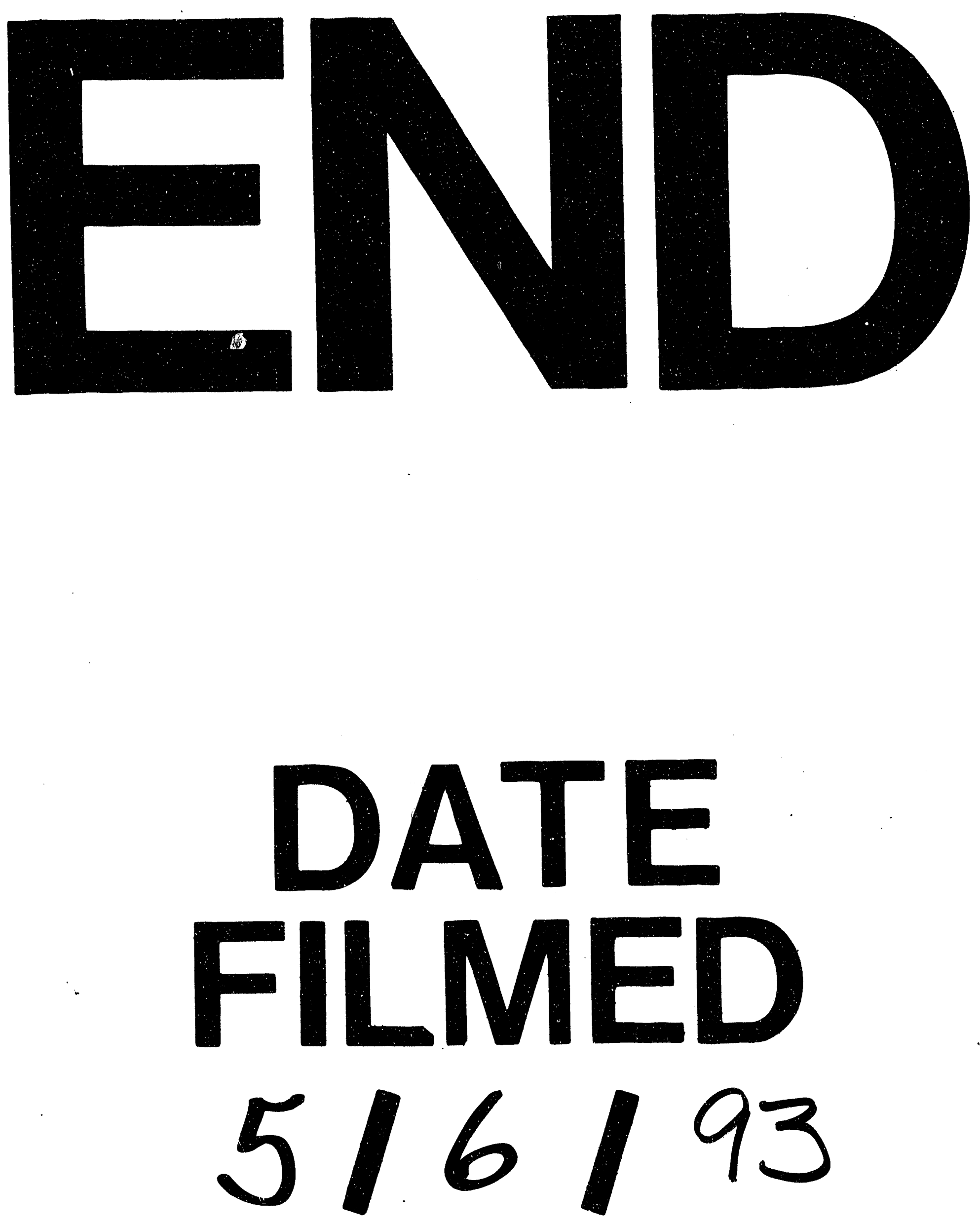
